Barna Balázs

Gamifikáció hatásának vizsgálata vállalati és oktatási közegben 
Számítástudományi Tanszék

Témavezető:

Fodor Szabina PhD habil.

(C) Barna Balázs 
Budapesti Corvinus Egyetem

Gazdaságinformatika Doktori Iskola

\section{Gamifikáció hatásának vizsgálata vállalati és oktatási közegben}

Doktori értekezés

Budapest 2020 



\section{TARTALOMJEGYZÉK}

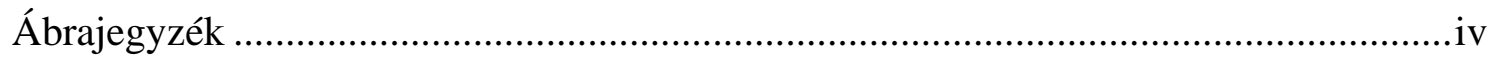

Táblázatjegyzék...............................................................................................vii

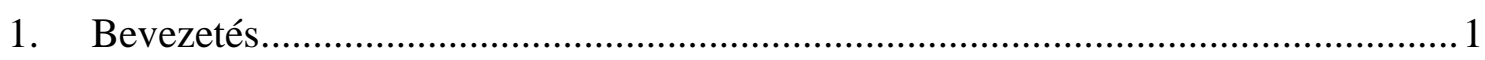

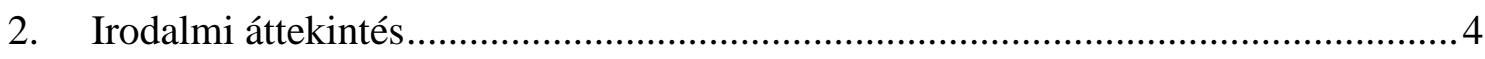

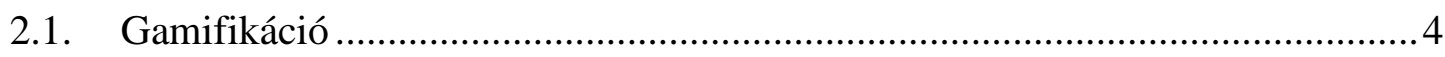

2.1.1. Fogalom-meghatározások ......................................................................

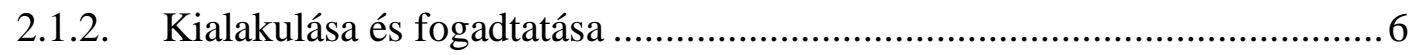

2.1.3. Csatlakozó tudományterületei ................................................................

2.1.4. Helyzete a vállalati közegben....................................................................

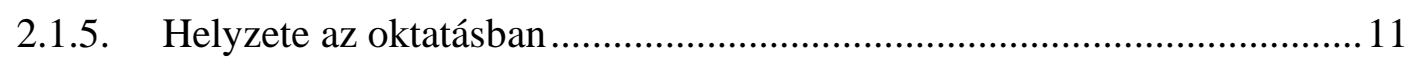

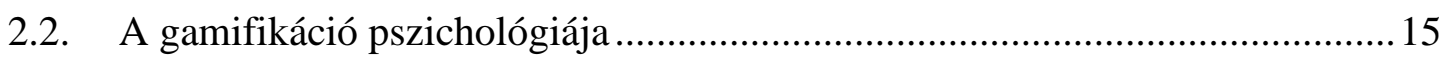

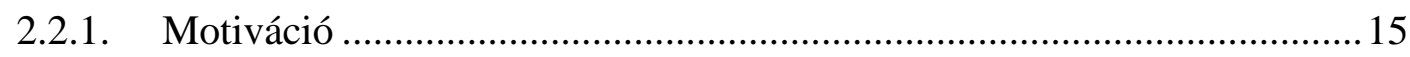

2.2.2. Belső és külső motiváció szerepe.............................................................. 16

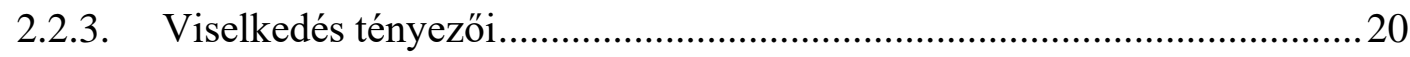

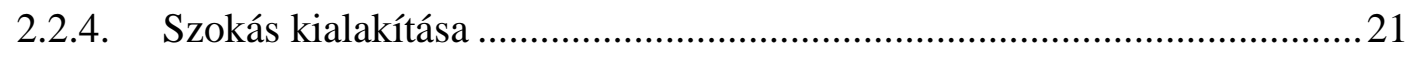

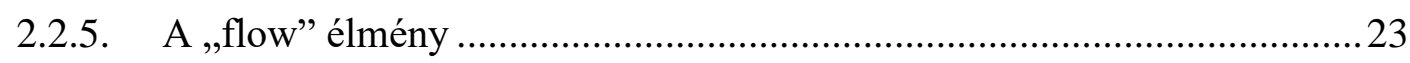

2.2.6. Munkahelyi motiváció, légkör és jóllét.......................................................24

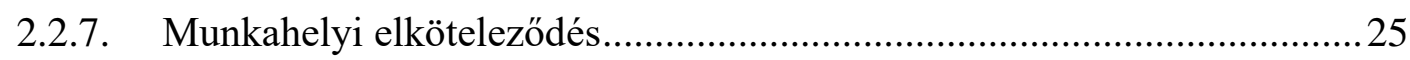

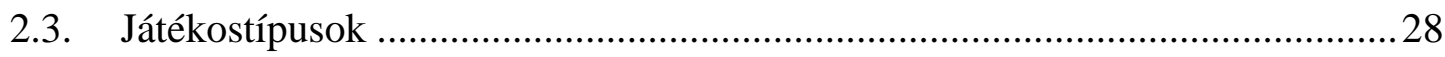

2.3.1. Myers-Briggs-féle Típusindikátor (MBTI) …………………………....... 30

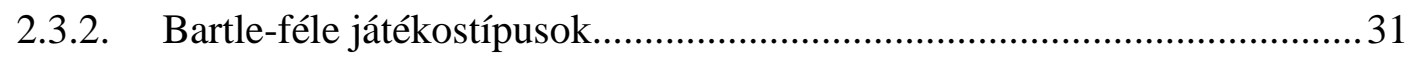

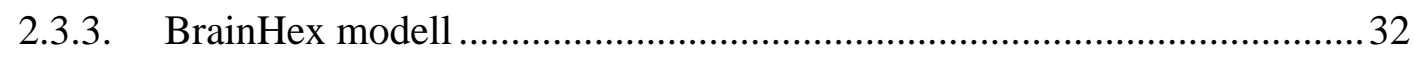

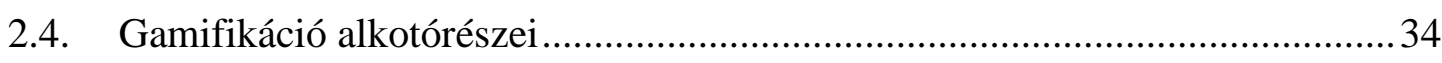

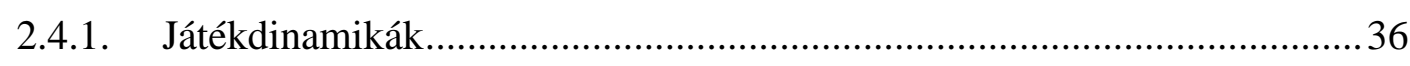

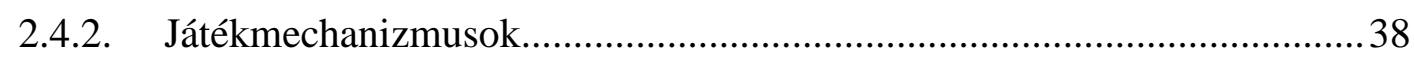

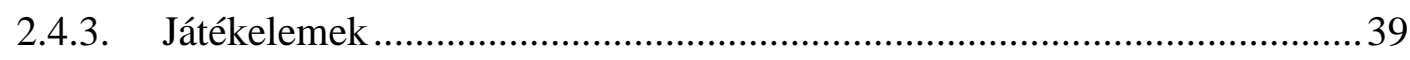

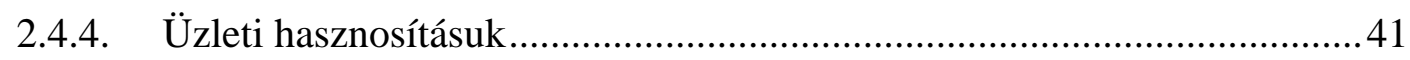

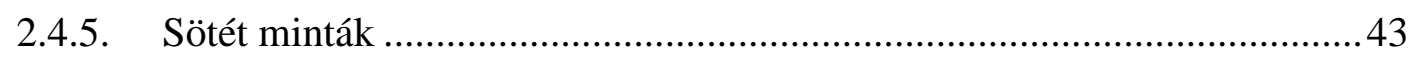




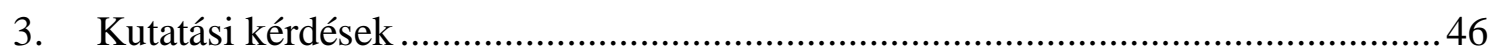

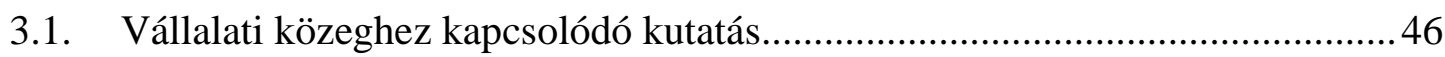

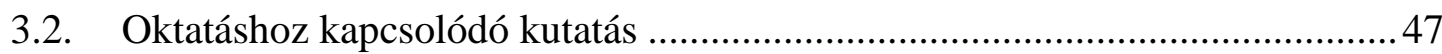

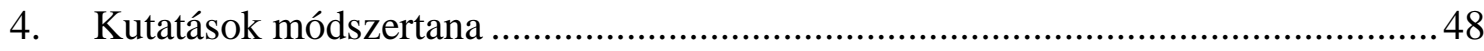

4.1. Vállalati közeghez kapcsolódó kutatások módszertana ..................................48

4.1.1. A vizsgált gamifikált csapatépítő alkalmazás (Battlejungle)...................49

4.1.2. A vizsgált gamifikált csapatépítő alkalmazás gamifikációs elemei ...........51

4.2. Oktatáshoz kapcsolódó kutatások módszertana .............................................55

5. Gamifikált csapatépítő alkalmazás hatása a munkavállalókra ...............................56

5.1. Vizsgálatba bevont felhasználók és cégek jellemzői ....................................56

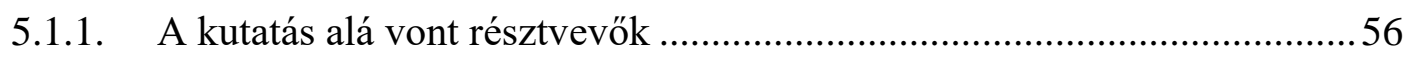

5.1.2. A kutatásban vizsgált szervezetek.....................................................59

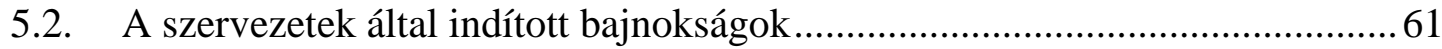

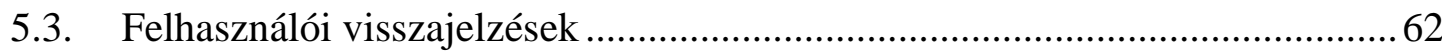

5.4. Felhasználók kategorizálása viselkedés alapján ............................................62

5.4.1. Elkötelezett felhasználók behatárolása ...................................................65

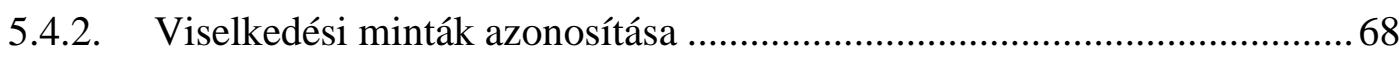

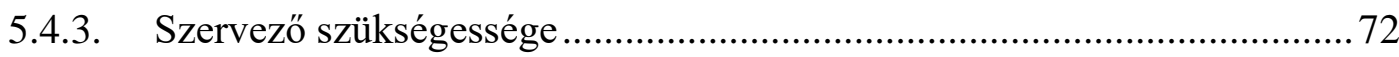

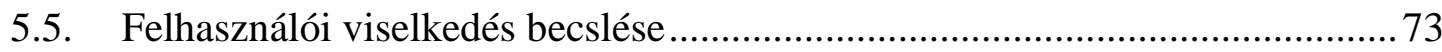

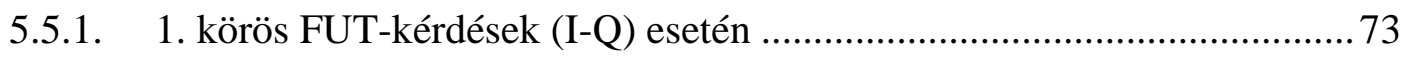

5.5.2. 2. körös FUT-kérdések (II-Q) esetén .................................................... 77

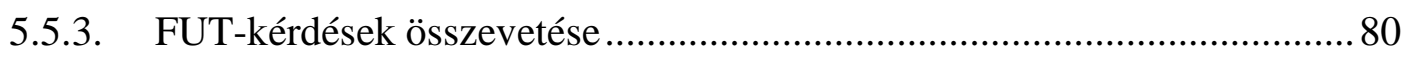

5.6. Munkahelyi légkör változásának elemzése .................................................. 82

5.7. Kapcsolati háló méretének és minőségének változása .................................. 83

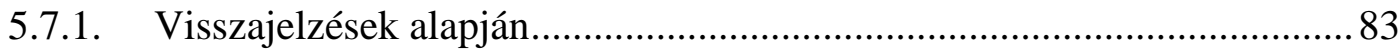

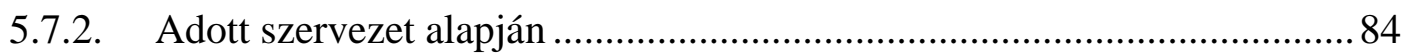

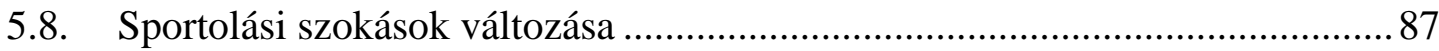

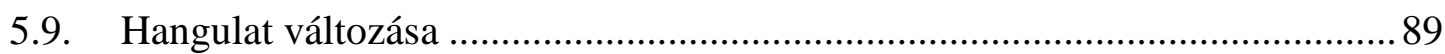

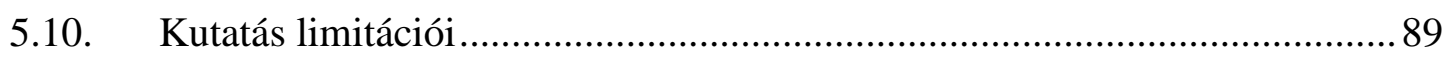

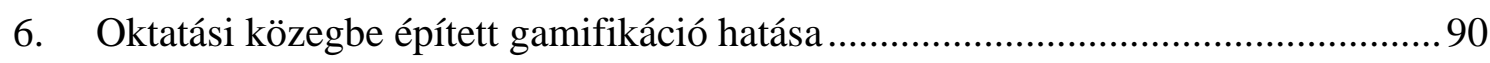

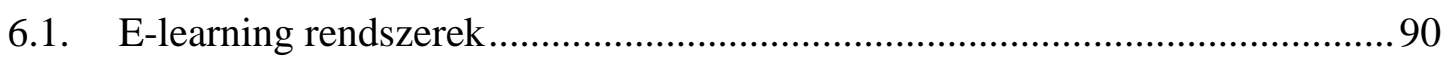


6.1.1. Budapesti Corvinus Egyetem által használt elektronikus oktatási rendszer 90

6.1.2. Moodle által nyújtott gamifikációs lehetőségek ....................................91

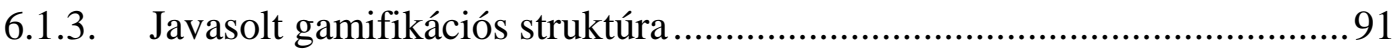

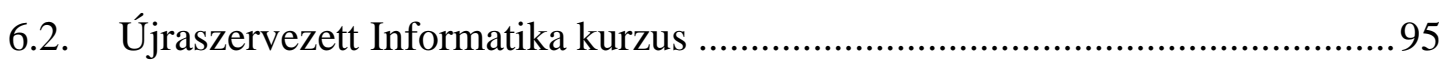

6.2.1. Gamifikációs átalakítás lépései ...............................................................96

6.2.2. A kutatás időszaka alatt bekövetkezett változások .................................98

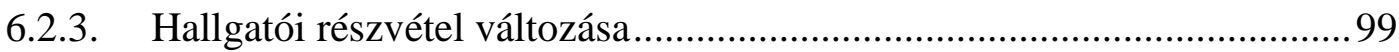

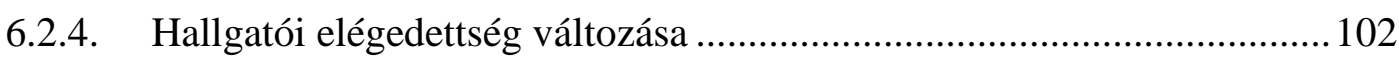

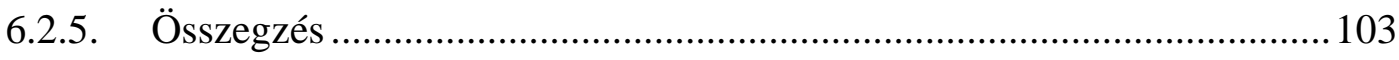

6.3. WebSec, a saját fejlesztésủ gamifikált oktatói platform ............................... 104

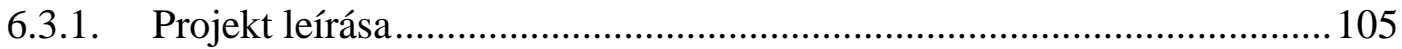

6.3.2. Gyakorlati alkalmazása .................................................................... 109

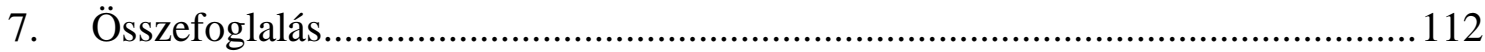

7.1. Vállalati közeghez kapcsolódó kutatások eredményei ................................. 112

7.2. Oktatáshoz kapcsolódó kutatások eredményei ............................................. 115

7.2.1. Moodle kurzus gamifikálásának eredményei......................................... 115

7.2.2. Oktatójáték eredményei ................................................................... 115

7.3. További fejlesztési tervek és irányok …….................................................. 116

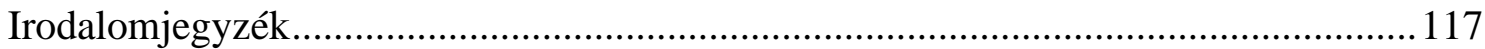

Tézis alapját szolgáló saját publikációk .................................................................. 129

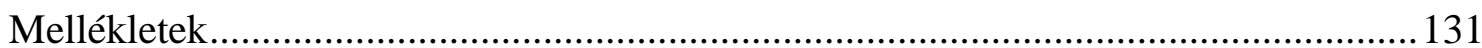

1. Melléklet: Visszajelzési kérdések ……........................................................ 131

2. Melléklet: Használatból eredő sportolási hajlandóságra vonatkozó visszajelzési kérdésekre adott átlagos értékelések időbeli változása ............................................ 133

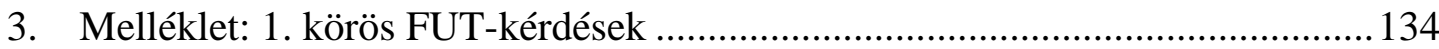

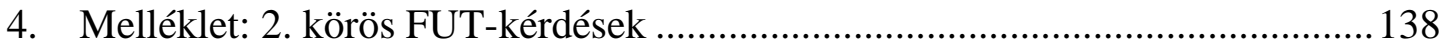




\section{ÁBRAJEGYZÉK}

1. ábra: Gamifikációhoz kapcsolódó területek ( (Barna, 2016) alapján) .......................... 8

2. ábra: Az öndeterminációs elméletböl levezetett 3 motivációtípus és szabályozásuk ( (Ryan \& Deci, 2000) alapján saját szerkesztés) ........................................................ 16

3. ábra: A FBM 3 tényezőjének kapcsolata ( (Fogg, 2009) és (Pusztai, 2018) alapján saját szerkesztés) 20

4. ábra: Eyal-féle horogmodell (Eyal, 2014)..... .22

5. ábra: A „Flow”-élmény fenntartása ( (Pusztai, 2018) alapján saját szerkesztés)........23

6. ábra: Az 5 legfontosabb motivációs tényezők fontossága* és jellemző** jelenléte a

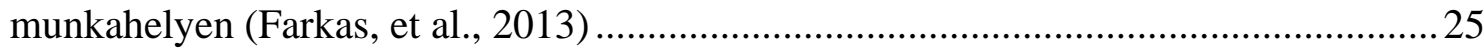

7. ábra: Munkavállalói elköteleződés világi és európai szinten (Aon, 2018) .................22

8. ábra: Videojátékok használatának gyakorisága (Fromann, 2018b) ...........................29

9. ábra: Bartle-féle 4 játékostípus (Fromann, 2012) ...................................................... 32

10. ábra: A BrainHex-modell alaptípusai ( (BrainHexBlog, 2008) és (Oliveira, et al.,

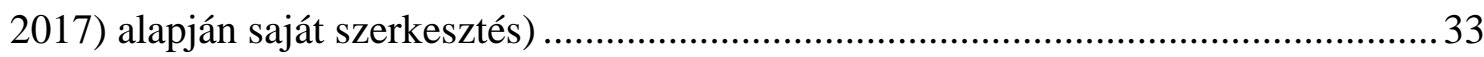

11. ábra: A gamifikáció alkotóelemei ( (Werbach \& Hunter, 2012) alapján) ................. 35

12. ábra: Gamifikációs játékelemek periódusos rendszere (Marczewski, 2017) ............39

13. ábra: Vállalati közeget érintő kutatás lépcsőfokai (Saját ábra) ................................. 48

14. ábra: Vállalati közeget érintő kutatás során felhasznált adatok és jellemzők (Saját ábra)

15. ábra: A Battlejungle rendszerében gyüjthető jelvények közül 3 darab (Battlejungle, 2019) .53

16. ábra: Oktatási közeghez kapcsolódó kutatás lépcsőfokai (Saját ábra) .55

17. ábra: A fiókkal rendelkező felhasználók eloszlásának változása országok szerint bontásban (Saját ábra). .58

18. ábra: 2017. április 1. és 2020. január 31-e között belépett felhasználók életkor (A) és nem (B) szerinti megoszlásának változása (Saját ábra) .59

19. ábra: A vizsgálatba bevont 51, legalább 10 fővel rendelkező szervezet lokalizáció és iparág szerinti besorolása (Saját ábra) 60 
20. ábra: Lemorzsolódott felhasználók arányának változása a használati idő függvényében (Fodor \& Barna, 2020)

21. ábra: „Elkötelezett” felhasználók karakterisztikái alapján végzett AHC típusú klaszterezés dendrogramja (Fodor \& Barna, 2020)

22. ábra: Adott aktivitás átlagos napi mértéke az „elkötelezett” felhasználókból képzett osztályok esetén (Fodor \& Barna, 2020).

23. ábra: Az „elkötelezett” felhasználók által a visszajelzési kérdésekre adott értékelések átlagos mértéke, osztályonkénti bontásban (Fodor \& Barna, 2020) .... 70

24. ábra: Pearson korrelációs mátrix hőtérképe (Fodor \& Barna, 2020) 71

25. ábra: „Elkötelezett” felhasználók megjegyzéseiből készített szófelhő (Fodor \& Barna, 2020) 71

26. ábra: „Elkötelezett” felhasználók aránya a szervezetekben szervezeti méret szerinti bontásban (Fodor \& Barna, 2020). .72

27. ábra: 1. körös FUT-kérdések közti korreláció (Saját ábra) .74

28. ábra: 1. körös FUT-kérdésekre adott válaszok eloszlása viselkedéskategória szerinti bontásban (Saját ábra) 75

29. ábra: 2. körös FUT-kérdések közti korreláció (Saját ábra). 77

30. ábra: 2. körös FUT-kérdésekre adott válaszok eloszlása viselkedéskategória szerinti bontásban (Saját ábra) 78

31. ábra: Munkahelyi légkör változása a szolgáltatás bevezetése után (Saját ábra) 82

32. ábra: A munkahelyi légkör megítélésének változása 4-hetes időszakblokkokra bontva (Saját ábra)

33. ábra: A munkahely légkörének és a kapcsolati háló méretének változása a vizsgált időszakban (Barna \& Fodor, 2018b)

34. ábra: Sorrendben indított események és versenyek résztvevőszáma, szervezőnkénti jelöléssel (Fodor \& Barna, 2020). .85

35. ábra: Felhasználók eloszlása részvétel szerint (Fodor \& Barna, 2020) 85

36. ábra: Eseményrészvételen alapuló kapcsolati háló (Fodor \& Barna, 2020) 87

37. ábra: A sportolási szokások változása a vizsgált időszakban (Saját ábra) 88

38. ábra: Javasolt gamifikációs struktúra a Moodle rendszerben jelenlévő alapelemek, létező pluginek és a szükségesnek vélt pluginek listájával (Barna \& Fodor, 2019a) .....94 
39. ábra: Az „Informatika” kurzus Moodle gamifikációs struktúrája az átalakítás elött és után ((Barna \& Fodor, 2019a) alapján saját szerkesztés).............................................98 40. ábra: A heti és „,mentőöv” teszteket legalább egyszer kitöltők aránya (Barna \& Fodor, 2018a) 101

41. ábra: Évközi teljesítmény bukási aránya hallgatótípusonkénti bontásban (Barna \& Fodor, 2018a) 102

42. ábra: Egy rosszul megválaszolt kvízkérdés, mely mutatja a helyes és helytelen jelöléseket, valamint tájékoztat a kapott büntetésről a jobb felső sarokban. (Barna, et al., 2019) 107

43. ábra: „WebSec” oktatóalkalmazás fejlettsége (Saját ábra) . 108

44. ábra: A) Játékmenetek időtartamuk szerinti sorrendben; B) Újrakezdett játékmenetek az egymásutáni játékmenetek közötti időtartamkülönbség szerinti sorrendben (Barna, et al., 2019) 110

45. ábra: Használatból eredő sportolási gyakoriság változása 4-hetes időszakblokkokra bontva (Saját ábra) 133

46. ábra: 1. körös FUT-kérdések eredeti változata ( (Barna \& Fodor, 2018d)) 135 


\section{TÁBLÁZATJEGYZÉK}

1. táblázat: Személyiség- és játékostípusok vizsgálatával foglalkozó kutatások ( (Hamari \& Tuunanen, 2014) alapján kiegészítve (Saját szerkesztés)) ........................................ 30

2. táblázat: MBTI preferenciapárjai (Mészáros, 2014) alapján.....................................31

3. táblázat: Alkotóelemekhez társított üzlethasznosítási célok (Hamari \& Lehdonvirta, 2010)

4. táblázat: „Vegyített” lebonyolítási elvü bajnokság „karma pool”-jának résztvevőnkénti pontnövekménye egészértékre kerekítve (Barna \& Fodor, 2018b)

5. táblázat: A 6 legnépszerübb sport a vizsgált szervezetek által indított bajnokságok alapján (Saját szerkesztés) 61

6. táblázat: Használatalapú karakterisztikák listája (Fodor \& Barna, 2020) alapján ......63

7. táblázat: Motivációval kapcsolatos kérdések (Fodor \& Barna, 2020) ......................... 64

8. táblázat: Jólléttel kapcsolatos kérdések (Fodor \& Barna, 2020) 64

9. táblázat: „Új felhasználók” számának alakulása a regisztráció óta eltelt idő függvényében (Fodor \& Barna, 2020)

10. táblázat: Új „,nem elkötelezett” felhasználók számának alakulása (Fodor \& Barna, 2020) 66

11. táblázat: „Elkötelezett” felhasználók használatalapú karakterisztikáinak statisztikai összegzése (Fodor \& Barna, 2020) 68

12. táblázat: Szemeszterenkénti hallgatószám az „Informatika” c. tantárgy esetén (Barna \& Fodor, 2018a) 96

13. táblázat: Választható visszajelzési témák 2015-ben (Barna \& Fodor, 2018a) 99

14. táblázat: „HalVel” kérdőív 2016. évi eredményeinek összegzése (Barna \& Fodor, 2018a) 103

15. táblázat: Kutatási irányvonalak összefoglaló felvezetése (Saját szerkesztés) 112

16. táblázat: A szolgáltatás által automatikusan feltett kérdések 132

17. táblázat: 1. körös FUT-kérdések és válaszopciói ( (Barna \& Fodor, 2018d) alapján saját szerkesztés) 
18. táblázat: 1. körös FUT-kérdésekre adott válaszok eloszlása viselkedéskategória szerinti bontásban (Saját szerkesztés)

19. táblázat: 1. körös FUT-kérdések adott opcióit választók átlagos szintje, részvétele, szociális funkciók használata és jelvénygyüjtése, feltüntetve az opciópárok közötti különbséget (Saját szerkesztés). 136

20. táblázat: 1. körös FUT-kérdésekre adott válaszok kombinációinak jellemzése (Saját szerkesztés) 137

21. táblázat: 2. körös FUT-kérdések és válaszopciói (Saját szerkesztés) 138

22. táblázat: 2. körös FUT-kérdésekre adott válaszok eloszlása viselkedés-kategória szerinti bontásban (Saját szerkesztés) 139

23. táblázat: 2. körös FUT-kérdések adott opcióit választók átlagos szintje, részvétele, szociális funkciók használata és jelvénygyüjtése, feltüntetve az opciópárok közötti különbséget (Saját szerkesztés). 139

24. táblázat: 2. körös FUT-kérdésekre adott válaszok kombinációinak jellemzése (Saját szerkesztés) 139 


\section{Köszönetnyilvánítás}

Szeretném megköszönni témavezetőmnek, Dr. Fodor Szabina docensasszonynak az évek alatt nyújtott töretlen támogatását és bizalmát. Közös munkáink, szakmai egyeztetéseink és baráti társalgásaink mind hozzásegítettek, hogy sikerrel elvégezzem a tanulmányaimat.

Köszönetet mondanék Dr. Baksa-Haskó Gabriella kollégának a kurzusátalakítási folyamatban való részvételi lehetőségem felkínálásáért. Szeretném köszönetemet kifejezni Kadobayashi Youki professzorúrnak, Tan Omiya kollégának és a NAIST intézményének, akik a Japánban töltött időszakom alatt szakmai és emberi támogatást nyújtottak. Köszönöm a Battlejungle csapat jelenlegi és volt tagjainak, munkájuknak köszönhetően születhetett meg az értekezésem egyik fö kutatási irányvonala. Ezen túlmenően szeretném megköszönni a Shinkendo közösségének, hogy biztosították, tanulmányaim mellett is megfelelő fizikai és szellemi edzésben részesüljek. Továbbá köszönöm T. Dvalin úrnak, aki erőt adott azáltal, hogy ő sem adta fel.

Végül pedig szeretném kifejezni szívből jövő, legmélyebb hálámat szeretett családomnak és barátaimnak, akik szüntelenül támogattak, segítettek, elviseltek, mindvégig hittek bennem és toltak előre. Hálásan köszönöm! 


\section{BEVEZETÉS}

Az utóbbi évtized egyik legnépszerübb hívószava a gamifikáció, mely megpróbálja a „szürke”, „,komoly” munkát és feladatot élvezetesebbé tenni. Gyakran használják marketing célokra, de emellett alkalmas a célszemélyek adott képességének fejlesztésére, a munkavállalói és hallgatói hozzáállás módosítására, valamint tudásátadásra is használható. Kutatásaim során a gamifikáció által nyújtott lehetőségek kiaknázását vizsgáltam vállalati, valamint oktatási közegben, ily módon munkáimat két, egymástól eltérö területen végeztem.

A gamifikáció, mint elv, nem újkeletű találmány, bizonyos elemeit mindig is használta már az emberiség. Ami újdonság, az a koncepcionális alkalmazása, az elemek összekapcsolása, az emberi motiváció megértése és erősítése, adott feladattal szembeni apátia csökkentése. Az egyre gyorsuló, információ-túltengésben szenvedő korszakban a figyelem felkeltése és a motiváció megtartása egyre labilisabb lábakon áll, így a játékok által használt figyelem-megragadási és célelérési kényszert kiváltó eszközök és praktikák segíthetnek eme labilitás csökkentésében.

Dolgozatomat a gamifikáció fogalmának körbejárásával és tisztázásával kezdem, kitérve annak fogadtatására és a kapcsolódó tudományterületeire, s átfogó képet mutatok a helyzetéről. Az emberi viselkedés, különösen a motiváció természetének megismerése lényeges pontját képezi a koncepció megfelelő alkalmazásának, így annak természetéről is tájékoztat a dolgozat, külön figyelmet fordítva a munkahelyi motivációra, a munkahelyi légkörre és a munkahelyi elköteleződésre. Az emberi viselkedés tükrében - noha két egyforma ember nem létezik - különféle csoportosítási elméleteket ismertetek, melyeket a gamifikáció témaköre játékostípusoknak nevez. Ezt követően a gamifikáció építőelemeinek bemutatását teszem meg, lehetőleg minél teljesebb képet adva a lehetőségekről, mely magába foglalja a játékelemeket, -mechanizmusokat, -dinamikákat és a játékélményt.

Munkáim egyik fele a vállalati közegben alkalmazott gamifikációra tér ki, különösen a munkahelyi légkörre gyakorolt változtató hatásáról. Az utóbbi években egyre nagyobb figyelmet szentelnek a vállalatok a munkavállalók elköteleződésének vizsgálatára és 
növelésére, annak érdekében, hogy fejlesszék a munkahelyi légkör minőségét, és növeljék a munkavállalók produktivitását. Egy gamifikációs elvek mentén felépített, sportos és játékos eseménysorozatok egyszerü lebonyolítását lehetővé tevő, csapatépítést segítő online szolgáltatás vállalaton belüli szociális környezetre gyakorolt hatását vizsgáltam, alapul véve az eszköz felhasználói bázisát, valamint a felhasználók viselkedésében, véleményében bekövetkezett változásokat. A szociális környezetre gyakorolt hatását három területre bontottam fel: a munkahelyi légkör változása, a munkatársak közötti kapcsolati háló kiterjedésének és minőségének alakulása, valamint a sportolási szokások módosulása. Ezen túlmenően az elkötelezett felhasználók viselkedéseit alapul véve (úgymint szolgáltatás használata, különféle eseményeken történő részvétel, teljesítménybejelentés, visszajelzési kérdésre adott válaszok stb.) klaszterelemzés útján játékoskategóriákba soroltam őket. Az értekezés továbbá kielemezte a felhasználók regisztrációjakor megjelenített kérdőívek hasznosságát, jellem-meghatározásban nyújtott szétválasztási képességét, összevetve a válaszolók életútjaival és a kialakult viselkedéseikkel. Esettanulmány jellegűen egy kiválasztott szervezet esetében megvizsgálásra került a szervezet kapcsolati hálója és a részvételi hajlandóság, kimutatván bizonyítékokat a „klikkesedésre” és a szervezői feladatkör szükségességére. Mivel közvetlen rálátásom nyílt a szolgáltatás nyújtotta lehetőségekre, folyamataira és müködésére, ez adta a motivációmat, hogy behatóbban foglalkozzak ezzel a témával.

Kutatásaim másik területe az oktatás felé irányul. Diákként magamon is és másokon is tapasztaltam a tanulási lelkesedés olykori hiányát, demonstrátorként és óratartóként pedig még inkább érdekelt, miképpen lehetne növelni a hallgatók elkötelezettségét, miként lehetne elérni a diákoknál a tanulásra irányuló belső motiváció felkeltését, s miként lehet az egy-egy fellángolásból a folyamatos tanulást elősegíteni. Mára általánossá vált, hogy a felsőoktatásban e-learning rendszereket használnak az oktatás során. Egy megfelelően felépített rendszer nemcsak a tananyagok tárhelyéül tud szolgálni, hanem segíteni tud a tananyag elsajátításában is. Noha egy kurzus sikere főként a tananyag minőségén alapul, gamifikációs elvek alkalmazásával növelhető a hallgatói motiváció. Vizsgálataim egy része a Moodle e-learning rendszert vizsgálta, amely egy hallgatóközpontú, magas szinten menedzselhető interfészt kínál a kurzusok számára. Először a 2015-ben átalakításra került, évente 1200-1500 hallgatót magába foglaló „Informatika” kurzus átalakításának hatásait (úgymint a hallgatói részvételben és elégedettségben bekövetkezett változásokat) és 
gamifikációs elemeit (többek között a jutalmazási rendszert, az alternatív tanulási útvonalakat és a visszajelzési lehetőségeket) vizsgáltam meg. Az értékelés magába foglalta a hallgatói részvétel változását, a vizsgán nyújtott teljesítmény változását, valamint a hallgatói elégedettségben bekövetkezett változást. Ezt követően a Moodle gamifikációs lehetőségeit mértem fel mélyrehatóan, s felállítottam egy javasolt struktúrát, mely alapján a vizsgált e-learning rendszer alkalmassá válhat magas szinten gamifikált kurzus tartására is. A Moodle rendszeren túllépve egy saját oktatóalkalmazás fejlesztésébe kezdtem, melynek célja egy adott terület tudásanyagának átadása. A tervezett alkalmazás oly módon készül, hogy játékszerü jellege miatt ne legyen szükség az oktató (vagy szakértő) folyamatos felügyeletére, képes legyen végigvezetni a felhasználót a teljes tananyagon. Dolgozatom során csak a tervezési és edukációs aspektusát taglalom, a szoftverfejlesztési lépésekre nem térek ki. Értekezésem tartalmazza az alkalmazás felépítését, a működése során használt játékelemek kapcsolatát, valamint a japán kollégák segítségével véghezvitt elsőkörös, kislétszámú tesztelését eredményét is.

Dolgozatom végén összegzem a munkáim során elért eredményeimet. 


\section{IRODALMI ÁTTEKINTÉS}

\subsection{Gamifikáció}

Mielőtt a gamifikáció fogalom pontos meghatározására rátérnénk, először érdemes a szó gyökerét, a „game” (játék) fogalmat kontextusba helyezni. A magyar nyelvben rendszerint ugyanazt a kifejezést használjuk a szórakoztató mivoltú időtöltésre, valamint a keretek és szabályok közé szorított, céllal és eredménnyel rendelkező rendszerben végzett elfoglaltságra, míg az angol nyelv ezeket elkülöníti „playing” és ,gaming” szavakra.

Az egyfajta rendszernek is tekinthető ,játék” (game) meghatározását Katie Salen és Eric Zimmerman úgy fogalmazták meg, mint „egy olyan szabályok alkotta rendszer, melyben a játékosok mesterségesen elöállított konfliktusokkal találkoznak, amelyek kimenetele számszerüsithetö eredményt hordoz magával" (Salen \& Eric, 2003). Alapul véve az iménti meghatározást, Raph Koster kiegészítette az érzelmi reakció koncepciójával. Elgondolása szerint „, a játék egy rendszer, melyben a játékosok interaktív módon absztrakt, szabályok közé szoritott kihívásokkal kerülnek szembe, tevékenységükröl visszajelzést kapnak, a teljesitményükröl számszerüsithetö eredményt közöl, mely gyakran vált ki érzelmi reakciót” (Koster, 2013). A játék „rendszer” jellege a játék terében létező elemek összekapcsolt együtteseként értelmezhető, minden elem hatással bír a rendszerre, és integrált részét képezi annak. A rendszerben elért eredményt pedig a játékos viselkedése és - a szabályok által engedélyezett, adott stratégiát követő - tevékenységei és akciói alapozzák meg. (Kapp, 2012)

\subsubsection{Fogalom-meghatározások}

A „gamification”, magyarosított verziója „gamifikáció”, avagy magyar megfelelője szerint ,játékosítás” definíciójának jelenleg nincs egy darab hivatalos változata, ám különböző szerzők elgondolásai alapján jól körül határolható a fogalom. Sebastian Deterding és társai elmélete alapján „a gamifikáció a játéktervezési elemek nem játékbéli kontextusban történő használatát” jelenti (Deterding, et al., 2011). Werbach és Hunter közös munkájukban hasonlóképpen határozták meg a jelentését, mint Deterding, csak ők külön 
megemlítik a játékelemeket is. Nézetük szerint a gamifikáció használata során játékelemeket és játéktervezési technikákat használunk nem játékbéli környezetben (Werbach \& Hunter, 2012).

A fenti definíciók csak a használat tényére térnek ki, azonban léteznek olyan meghatározások is, melyek a gamifikáció célját is megjelölik. A Bunchball által 2010-ben kiadott leírásuk alapján a gamifikáció a játékok mechanizmusát alkalmazza nem játékszerü cselekedetekben annak érdekében, hogy megváltoztassa az emberek viselkedését, részvételt és elköteleződést váltson ki belölük. (Bunchball, 2010)

Velük ellentétben Gabe Zichermann és társa inkább folyamatként tekintenek a gamifikációra, és definíciójukban nemcsak a használat módját, hanem a használat célját is megjelölik, egészen pontosan „, gamifikáció az a folyamat, melynek során játékszerü gondolkodást és játékmechanizmusokat használnak fel a felhasználók elkötelezödésére és problémák megoldására" (Zichermann \& Cunningham, 2011).

Vállalati közegben némileg módosul a gamifikáció értelmezése, ugyanis át kell szőnie különböző üzleti területeket, beleértve a humánerőforrást, a vállalatirányítási (ERP $\left.{ }^{1}\right)$ rendszereket, az információtechnológiát, a projektmenedzsmentet, a piackutatást és a marketinget (Raftopoulos, et al., 2015). Ily módon a vállalati gamifikáció a ,játékélmények elönyeit kihasználó szolgáltatásfejlesztési folyamat, mely támogatja a felhasználó általános értékteremtését" (Huotari \& Hamari, 2012).

A szóban forgó fogalom mellett számos, egymáshoz képest hasonló tartalmú fogalom kering a tématerületen, mely meghatározások egy-egy aspektusának kiemelésével jellemzik a jelenséget. Ilyen meghatározás például a „termelékenységi játék” (McDonald, et al., 2008), a „megfigyelt szórakoztatás” (Grace \& Hall, 2008), a „funware” (Takahashi, 2008), a ,játékos tervezés” (Ferrara, 2012), a ,játékréteg” (Priebatsch, 2010) vagy épp az ,,alkalmazott játék” (DGA, 2017) és ,,alkalmazott játéktervezés” is (Dodds, 2015). A fogalom szórakozásra irányuló sugallata (,game”) miatt előfordul, hogy inkább „elköteleződési projekt”-ként vagy „elismerési és motivációs program”-ként hivatkoznak rá, de használatos még a „meggyőzési tervezés” és „viselkedésmenedzsment” (Dodds, 2015), valamint az „emberközpontú tervezés” és „motivációalapú tervezés” (Kuo, 2013) is.

\footnotetext{
${ }^{1}$ Enterprise Resource Planning
} 
A dolgozat során a gamifikáció fogalma Zichermann és Cunningham meghatározásán alapul, kiegészítve Deterding és társai, valamint Werbach és Hunter megfogalmazásában szereplő kontextus kiemelésével, megjelölvén annak célját is. Ezek alapján a továbbiakban az alábbi meghatározással él a dolgozat:

\section{A gamifikáció egy olyan folyamat, melynek során játékszerü gondolko- dást és játékszerü tervezési elemeket (játékdinamikákat, -mechanizmuso- kat, -elemeket) használnak fel nem játékbéli kontextusban annak érdeké- ben, hogy a felhasználót elkötelezödésre sarkallják, egy adott probléma megoldásában segítsék, vagy egy készségét/képességét felfedjék vagy fej- lesszék.}

A fogalomhoz olykor leegyszerüsített, elnagyolt tulajdonságokat, képességeket rendelnek, így tévesen interpretálják adott szituációkban, emiatt hamis elvárásokat és müködést társíthatnak hozzá. A gamifikáció nem merül ki a pontok, jutalmak és jelvények hármasában, nem lesz tőle triviális a tanulás és nem használható minden folyamatra. Alkalmazásához továbbra is szükséges a szakemberek felügyelete és szakértelme. (Kapp, 2012)

\subsubsection{Kialakulása és fogadtatása}

Játékelemek használata nem újkeletű módszer, különböző célokra már korábban is használták, azonban a gamifikáció tudatos használatának kezdete a 2000-es évekre datálható. A fogalom első felhasználása 2003-ra tehető, amikor Nick Pelling, egy brit játékfejlesztő, javasolta az elektronikus eszközökre tervezett játékszerü interfészek használatát. A következő években a fogalom némileg tévesen használták, míg a ma is használatos jelentésének formáját 2010 tájékán nyerte el. (Werbach \& Hunter, 2012)

A hagyományos elvű működést és tevékenységet gamifikáló módszer támogatói elsősorban a felhasználói motiváció fokozódását, az adott folyamatban történő részvétel növekedését, valamint az elköteleződés erősödését várják. A módszer ellenzői viszont mindössze pontgyüjtésen alapuló változtatásoknak, „,pointsification”-nek (Robertson, 2010), vagy épp kihasználási technikáknak (,exploitationware”) vélik (Bogost, 2013), s nem látják a lényeges játékelemek megfelelő használatát. A kifejezés használatát mindössze egy 
marketing eszköznek tudják be, amely magával ragadó játékélményt ígér, de csak értelmetlen pontvadászatot nyújt (Morrison \& DiSalvo, 2014). Ezen túlmenően - ahogyan Scott Nicholson is rámutat - tartanak attól, hogy a gamifikáció által nyújtott külső motiváció a személyes késztetésre negatív hatást gyakorol, csökkentve ezzel a belső motiváció mértékét (Nicholson, 2012), emiatt ha egyszer valakit már elkezdtek jutalmazni, azt az illetőt folyamatos jutalomhurokban szükséges tartani (Zichermann \& Cunningham, 2011). Ezzel kapcsolatban azonban fontos megemlíteni - a tanulási motivációban végzett kutatások meglátásai alapján -, ha a témakör eleve alacsony érdeklődést váltott ki a tanulóban, a jutalmazási rendszer nem csökkenti a belső motivációt, hiszen eleve meglehetősen alacsony volt ennek a mértéke (Nicholson, 2012).

\subsubsection{Csatlakozó tudományterületei}

Siobhan O’Donovan és társai egy tanulmányukban megfogalmazták (O'Donovan, et al., 2013), hogy egy hatékony játéknak (vagy játékszerü alkalmazásnak) motiválónak, addiktívnak és ösztönzőnek szükséges lennie, mely lehetőséget ad rövidtávú célok elérésére, miközben fenntartja az eshetőséget a hibázásra, elbukásra, ahogyan az újrapróbálkozásra is mindaddig, míg a felhasználó sikerrel nem jár.

Annak érdekében, hogy egy megfelelően gamifikált folyamat jöjjön létre, nem elegendő csak a játékelemekre hagyatkozni. A létrehozás folyamata különböző területek meglátásait használja fel. A folyamatszervezőnek figyelembe kell vennie a játékelméleteket, a játéktervezési elveket, az adatbányászati módszereket a nagy mennyiségű adathalmaz feldolgozásáért, a pszichológiai irányelveket a felhasználók viselkedésének és motivációjának megfelelő ráhatásáért, valamint rendszer- és adatbázistervezési ismeretekkel is szükséges rendelkeznie. (Barna, 2016) (1. ábra) 


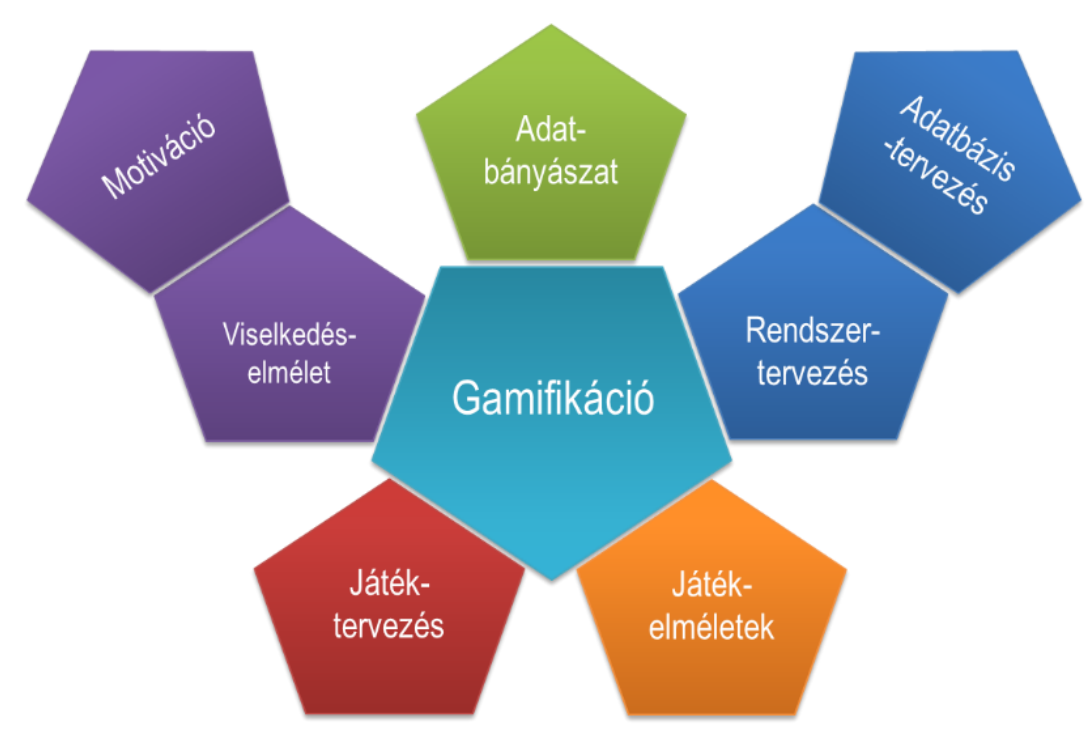

1. ábra: Gamifikációhoz kapcsolódó területek ( (Barna, 2016) alapján)

\subsubsection{Helyzete a vállalati közegben}

A gamifikációt vállalati közegben nagy mértékben használják ügyfélkörbővítő marketingeszközként. A gamifikált megoldásokat alkalmazzák az alkalmazottak elköteleződésének növelésére, hogy jobban hozzá tudjanak járulni a cég stratégiai és tervezési folyamataikhoz (Markets and Markets, 2016), ám felhasználható a munkavállalók képességeinek felfedésére és fejlesztésére is, melyre hagyományos keretek között nem adódna lehetőség. A gamifikált megoldások segíthetnek „kitárulkozni” a munkavállalóknak, ily módon a munkaadó is tisztább képet kap az elérhető céges képességekröl.

A gamifikáció a modern üzleti tudományokban már évek óta jelenlévő elgondolás és kutatási irány. A Markets and Markets 2016-os tanulmánya alapján (Markets and Markets, 2016) a gamifikáció piacának értéke 2015-ben 1,65 milliárd USD körül mozgott, s ez várhatóan 2023-ra eléri a 11,1 milliárd USD értéket. A piac összetett éves növekedési rátája eléri a (meglehetősen impresszívnek tartott) 46,3\%-ot, köszönhetően az egyre növekvő gamifikációs megoldások és applikációk iránti igényeknek mind fogyasztói, mind vállalati oldalról. A Markets and Markets kutatóintézet a piac egyik fő mozgatórugójának a BYOD ${ }^{2}$ szemlélet vállalaton belüli elterjedését és a közösségi média (szintén belső közegben) növekvő használatát jelöli meg. A közösségi média munkavállalók és ügyfelek

\footnotetext{
${ }^{2}$ BYOD: Bring Your Own Device - "Hozd a saját eszközödet"
} 
közötti, különböző célú használata megnövelte a szervezetről a közösségi médiában kialakított kép jelentőségét. (Markets and Markets, 2016)

\subsubsection{Fogyasztóközpontú alkalmazások}

A gamifikáció piacának szereplői között találhatóak megoldást kínálók, IT-fejlesztők, rendszerintegrátorok és egyéb játékosok. A piac legnagyobb szolgáltatói közé sorolható a Microsoft, Salesforce, Badgeville, Bunchball, Arcaris, Gigya, SAP SE, Bigdoor Media, LevelEleven, és Faya Corporation. Ezek a szervezetek a piaci igényeknek való megfelelés és azok kielégítése végett különböző stratégiákat foganatosítottak meg a termékfejlesztések, fúziók, partneri kapcsolatok, együttmüködések és üzleti bővítések terén. (Markets and Markets, 2016)

Azok az egészségmegőrzést célzó alkalmazások (pl. Endomondo, Nike+ Running, Fitbit One, Fitocracy, Adidas MiCoach) is népszerüek lettek, melyek a gamifikáció lehetőségeit használták ki, hogy a felhasználóikat ösztönözzék a mozgásra. Ezek az alkalmazások egyénenként ösztönzik a játékosait, a közösségi élményt az eredmények megosztása és a ranglisták adják többnyire.

Számos megoldás létezik a civil felhasználó mindennapi életének megsegítésére, kezdve a már említett fitnesz appoktól, a produktivitást serkentő teendő-lista alkalmazásokon (Bounty Tasker, Epic Win, SuperBetter, Forest App, Habitica) és a kiadásfelügyelő megoldásokon (Smarty Pig) át a legkülönfélébbekkel lehet találkozni (Chou, dátum nélk.). Az Emirates NBD bank kiadott egy olyan fitnesz applikációt, amivel kedvezőbb kamatot érhetnek el az ügyfelek, ha mindennap megtesznek 12 ezer lépést (Babrovich, 2017). Bizonyos esetben a pozitív megerősítés és sarkallás mellett agresszívabb büntetést is bevezettek, mint például a Beeminder ${ }^{3}$ produktivitást segítő megoldás esetében, ahol, ha a felhasználó nem teljesíti határidőre a maga által kitüzött célt, akkor az elözetesen bekötött bankkártyájáról levonnak egy adott összeget.

Tudományos kutatásokban való felhasználására megfelelő példát nyújt a Sea Hero Quest, egy 2016-ban futtatott játék. A történet szerint egy kisfiú hozzájut demenciában szenvedő halász édesapja naplójához, amivel megtalálhatja apja emlékeit. A játékmenetek során

\footnotetext{
${ }^{3}$ https://www.beeminder.com/
} 
keletkezett felhasználói adatokat (úgymint reakcióidő, manőverező-készség) egy globális, demencia elleni kutatásban használták fel. A kezdeményezés egyik fó pozitívuma, hogy a laboratóriumi körülményekhez képest 150-szeres hatékonysággal bírt, ugyanis 2 percnyi játék ki tudott váltani egy 5-órás laboratóriumi vizsgálatot. A kampány másik előnye az elérésben mutatkozott, ugyanis míg a témában az eddigi legnagyobb kutatás 600 fö bevonásával tudott lefutni, addig az alkalmazást közel 3 millió alkalommal töltötték le. (Pusztai, 2018)

A gamifikáció nem feltétlenül elektronikus megoldásokban jelentkezik. Elég csak arra gondolni, amikor a kisétkezdék pecsétet adnak egy-egy vásárlás után, és bizonyos számú pecsét összegyüjtésekor kedvezményre vagy egy ingyen étkezésre jogosult a vásárló. Ugyanez igaz a pontgyüjtős akciókra és pontalapú hüségprogramokra. A pontok növekedését az előrébb jutás pszichológiai hatását vonja maga után, ebből kifolyólag megnő az ügyfél számára az érték, amit a bolt/étkezde/stb. tud nyújtani számára.

A fogyasztásösztönző és fogyasztó-megtartó megoldások mellett léteznek olyan alkalmazási példák, melyek a közösségi és közúti szabályok betartását ösztönzik pozitív megközelítéssel. Stockholmban 3 nap erejéig tesztjelleggel bevezették a traffipax-lottót, melynek során a sebességhatárt betartó autósok automatikusan részt vettek egy nyereménysorsoláson. A nyereményeket pedig a gyorsan hajtó autósok büntetéseiből finanszírozták. Az akció során a traffipax előtt elhaladó 25000 autó átlagos sebessége 22\%-kal volt alacsonyabb, mint az a tesztidőszakot megelőző napokban. (Liszewski, 2010)

\subsubsection{Vállalati folyamatközpontú alkalmazások}

A vállalatok belső, humánalapú folyamatainak fejlesztésére is kiválóan szolgál megoldásokkal a gamifikáció, feltéve, ha azt megfelelően tálalják, és nem pedig „erőltetett” a használata. A Salesforce Motivation kifejezetten az értékesítési osztály dolgozói körében alkalmazható, amely pontozással, folyamatindikátorokkal, csapatranglistával hajtja előre az értékesítőket. A Badgeville a kitüzött célok elérését, képesség fejlesztését különféle jelvényekkel jutalmazza, mely jól használható a munkavállalók önfejlesztésére. A Badgeville ügyfelei között tudhatja a Deloitte-ot, a Samsungot és a Dellt is. Az SAP saját fórumalapú tudásmegosztó oldala, az SAP Community Network is játékosított elemekkel tarkította müködését. Posztok és kommentek írásáért (valamint azok minőségéért) 
jutalompont jár, amik alapján rövidtávú és örök-ranglistát állítanak fel, valamint megkülönböztető státuszszinteket szerezhetnek vele a felhasználók. A pontjaikat valós nyereményekre is beválthatják (pl. póló), ám jellemzőbb, hogy jótékonysági adományra fordítják (Chou, 2013). Az újonnan érkező munkavállalók beiktatását fejlesztették és rövidítették le a Sykes vállalat esetén, ahol az elavult diasorokat lecserélték egy kidolgozott narratívával rendelkező, erősen szociális és kollaboratív elemekre építő osztálytermi struktúrára, kiegészítve multimédia-anyagokkal és szimulációkkal. A változtatás során az eredeti 5-napos beiktatási időt sikerült lecsökkenteniük 3 napra, valamint az egykor lehangoló elégedettségi szintet 92\%-ra tornázták fel. (Centrical, dátum nélk.)

\subsubsection{Helyzete az oktatásban}

Az oktatás hagyományos folyamata - miszerint az oktató a tanórák keretében adja át a tudásanyagot a hallgatóságnak egyirányú kommunikáció keretében (melyet a nemzetközi köznyelv „,chalk and talk”-nak is nevez) - lassan veszít erősségéből, noha népszerüsége 1995 és 2010 között lényegében stagnált (Watts \& Schaur, 2011), melyhez hozzájárul az egyre szélesebb körben alkalmazott online környezet. Egy játék során az iránymutatás már nem egy meghatározott személytől származik, hanem a játék mechanikájába kerül beépítésre (Niman, 2014), bár annak előkészítésére és felügyeletére továbbra is szakértő szükségeltetik (Kapp, 2012). A motiválatlanság és az önkéntesség hiánya jelentős problémát jelent, számos oktatási kudarc mögött állhatnak eme indokok (Rab, 2015). Az oktatás helyzetének javulásához hozzájárulna, ha az iskolai életben növelnék az önkéntesség és az interakció mértékét, valamint bővítenék a személyre szabottság lehetőségét (Rab, 2012).

A gamifikáció alkalmazása az egyik legnépszerübb stratégiává nőtte ki magát, mely elösegíti a tanulás iránti motiváció és elköteleződés erősítését szolgáló módszertanok fejlesztését. Az oktatásban használt gamifikáció népszerüsége abból a szempontból is érthetö, miszerint a játékok és az osztályterem között átfedések mutatkoznak. A játékosok azon dolgoznak, hogy elérjenek egy (vagy több) bizonyos célt és végül győzzenek, miközben a diákok azon dolgoznak, hogy adott tanulmányi célokat érjenek el és megfelelö akadémiai teljesítményt nyújtsanak. A játékosok szintről szintre fejlődnek a teljesítményük alapján, a tantermi hallgatóknak pedig különböző szintü kurzusokat kell 
teljesíteniük, és el kell sajátítaniuk a meghatározott témaköröket az akadémiai fejlődésükhöz (Jackson, 2016). Maga a tanulás egy interaktív folyamaton keresztül zajlik, amely magában foglalja a megpróbáltató környezetet, adott esetben a más játékosokkal való konfrontációt, valamint a mesterségesen előállított akadályozók leküzdését (Niman, 2014).

A gamifikáció koncepciójának alkalmazására számos példa létezik az oktatásban és az oktatásjellegü aktivitásokban, mint például a Duolingo, mely nagy népszerüségnek örvend a nyelvoktatás terén, vagy éppen a Lumosity, mely a mentális képesség szinten tartásában és erősítésében játszik szerepet (Barna, 2016). A Markets and Markets jelentése szerint az oktatási gamifikáció piacának értéke a 2018-as 450 millió USD-ről 2023-ra várhatóan 1,8 milliárd USD-re fog nöni. A növekedés legfőbb elemei között említik az egyre emelkedő mértékű digitális tanulás alkalmazását, valamint a szervezetek körében egyre növekvő felhőalapú szolgáltatások használatát. (Markets and Markets, 2019)

Az oktatási környezet és tanítási folyamatok gamifikálásában jelentős potenciál rejtőzik, hiszen a hallgatói motiváció nem kellő nagysága rendszeresen visszatérő probléma. Noha a gamifikáció viszonylag könnyen alkalmazható oktatói alkalmazásokban, számos kihívás rejlik még benne: különböző viselkedés és hozzáállás a játékszerü alkalmazásokhoz, játékfejlesztők bevonása az oktatói tevékenységekbe, vagy épp az alkalmazás játékelveinek kiválasztása bizonyos bonyolultabb tanulmányi feladatok kapcsán. Maga a gamifikációt nem szabad csodaszernek tekinteni, ami mindig és folyamatosan megold minden oktatói problémát, hanem inkább a sok hatékonyságnövelö eszközök egyikeként érdemes kezelni. Lévén a gamifikáció viszonylag új jelenség, így a többi eszközhöz mért költséghatékonyságának megállapítása még nem forrott ki. (Barna \& Fodor, 2018a)

Ha sikerrel járna a hallgatók elköteleződésének növelése, akkor az szignifikáns jelentőségü pozitív hatással lenne az oktatás hatékonyságára. A gamifikáció alkalmas eszköznek bizonyulhat a tanulási folyamat során a különféle lehetőségek hozzáadásával és a tananyag személyre szabásával. (Barna \& Fodor, 2018a)

Egyik lényeges jellemzője a gamifikációnak, hogy a gamifikált alkalmazás többnyire online, digitális technológián alapulnak. Lényeges szempont, mivel a jelenlegi hallgatói bázist a Y-generáció (az 1980-as évek közepe és az 1990-es évek közepe között születettek) és a Z-generáció (a '90-es évek közepétől a korai 2000-es években születettek) tagjai 
alkotják, kiknek tanulási és információszerzési szokásaik merőben eltérnek a korábbi generációéktól. Az Y- és Z-generáció képviselői kényelmesen, természetesen és gyakran használják az internetet és a közösségi médiát, hisz életük korai szakaszától már szerves részét képezik az életüknek és a szocializációs folyamataiknak (Horovitz, 2012) (Bíró, 2014).

Egy másik lényeges vonása a Z-generáció tagjainak, hogy esetükben megfigyelhető a figyelem fenntartásához szükséges készség csökkenése (Fromann, 2012). Erre jelenthet megoldást a gamifikáció, ami segít a tanulási folyamatot kisebb lépésekre szétbontani, valamint különféle stílusú és mértékű pozitív megerősítéssel a motivációjuk is növelhető (Horovitz, 2012).

A gamifikáció hatása még nagyobb lehet, ha információkat tudunk gyüjteni a gamifikált platformokról. Az ilyen információkra épülő elemzések eredményei lehetővé teszik, hogy a tanulók speciális igényeikhez és a tanulási ütemeikhez lehessen igazítani az oktatásjellegü gamifikációs célokat és elveket. (Barna \& Fodor, 2018a)

\subsubsection{Tanórák és kurzusok gamifikálása}

Számos kísérlet és tanulmány zajlik a gamifikáció köz- és felsőoktatásban való használatáról. A Khan Academy 2012-ben gamifikálta Számítástudomány címü tantárgyát, amiben a diákok két programozási nyelvvel (JavaScript és Python) ismerkedhettek meg interaktív formában. Briana B. Morrison és Betsy DiSalvo az említett kurzust vizsgálták meg tanulmányukban. Eredményük alapján az ötlet kiváló volt, ám a Khan Academy nem fektetett kellő hangsúlyt a jelentőségteljes tartalomra, valamint szükre szabott volt a célok kiválasztása feletti szabadságérzet. (Morrison \& DiSalvo, 2014)

A Cape Town Egyetem Számítástudományi Tanszéke a játékfejlesztő kurzusuk gamifikálása mellett döntött. Az átalakítás célja - többek között -, hogy kiterjessze a hallgatók ismeretét az adott témakörben, növelje a jelentőségteljes részvételt, és fejlessze a problémamegoldási készséget. A kurzus rendelkezett egy kitalált történettel, és a tanterv ezen keresztül vezetett végig. A sztorit egy minőségi grafikai munkákkal megtámogatott honlapon lehetett elérni. A diákok az elért eredményeik alapján a valós életre kihatással levő lehetőségekre válthatták be, példának okáért felhasználhatták arra, hogy maguk számára kitolják egy beadandó határidejét. (O'Donovan, et al., 2013) 
Domínguez és szerzőtársai által jegyzett tanulmány során egy gamifikált e-learning rendszer hatásait és kimenetelét vizsgálták. Az eredményeik között szerepel az a megállapítás, miszerint a gamifikáció jelentős érzelmi és szociális hatással bír a hallgatókra. Ennek oka lehet az, hogy a jutalmazási rendszere és a kompetitív szociális mechanizmusai motivációs hatással bír rájuk. Azonban arra is rámutattak a szerzők, hogyha egy felhasználónak az első használatkor nehézségei támadnak egy ilyen jellegü alkalmazás müködésének megértésével, akkor rögtön elbátortalaníthatja őt a további használattól. Ezenfelül, ha az alkalmazás nem biztosít teljesen folyamatos müködést, és a folyamat gyakran megszakad technikai okok (pl. hibás müködés vagy hosszú feldolgozási idő) vagy adminisztratív okok miatt, az alkalmazás nem fog tudni kellő motivációt biztosítani a hallgatók számára. (Domínguez, et al., 2013)

\subsubsection{Gamifikált oktatóalkalmazások}

Több gamifikált alkalmazás is elérhető az oktatók számára, melyek a tanórai aktív részvételt, az elköteleződést és a tanulói motivációt hivatottak fejleszteni. A jelenlegi megoldások többnyire az általános iskolai kurzusok átalakítását célozzák meg, ám magasabb szintü tantárgyak esetén is felhasználhatóak. Ilyen jellegü oktatói segédeszközök például a Socrative, Kahoot!, Classraft (Lynch, 2017), bár megjegyzendő, hogy az ilyen jellegü eszközök folyamatos felügyeletet igényelnek egy oktató vagy szakértő által, mivel csak egy néhány perces feladatot tudnak nyújtani (mint például a Kahoot! esetében), vagy egy továbbfejlesztett adminisztratív eszközként funkcionálnak (pl. Classcraft) (Barna, et al., 2019).

A Massachusetts Institute of Technology (MIT) Media Lab által készített Scratch ${ }^{4}$ online szolgáltatás a programozás és a játéktervezés tanulását segíti oly módon, hogy saját projekteket, játékokat és animációkat hozhatnak létre a felhasználók, melyeket online elmenthetnek, megoszthatnak, illetve már meglévő projektekből leszármaztathatnak saját projekteket (azaz készítenek belöle egy másolatot, melyet szabadon tovább módosíthatnak). Az alkotók állítása szerint a szolgáltatás segít a kreatív gondolkodásban, a szisztematikus érvelés képességének fejlesztésében és az együttmüködési készség erösítésében (Scratch, dátum nélk.).

\footnotetext{
${ }^{4}$ https://scratch.mit.edu/
} 


\subsection{A gamifikáció pszichológiája}

A XIX. század egyik aggodalmát a termelésben folyamatosan felaprózódó munkamegosztás keltette elidegenedés és személytelenség növekedése szolgáltatta, mivel a dolgozó által hozzáadott érték jelentősége csökkent, eltávolodott a készített terméktől, a teljes előállítási folyamat helyett csak egy rövid, általános feladat elvégzését várták el tőle (Dolan, 1971). Hasonló elidegenedés tapasztalható az oktatásban is, mely során az egyre elméletibb központú tananyag a szélesebb körű alkalmazhatósága miatt egyre általánosabb, átfogóbb lett, és az elsajátított anyag specifikus alkalmazásokra történő használata egyre nehezebbé vált (Krueger \& Kumar, 2004). A tömegoktatás erösödésével - mely során a hallgatók többsége szakmai értelemben érdemben nem érintkezik az oktatóval, a hallgatószám miatt a tananyagok standardizáláson esnek át - tovább erösíti az elidegenedés, személytelenség érzetét. Ha sikerül egy olyan oktatási élményt kínálni, melyben a tanulást a hallgatók is esszenciális elemének tartják a saját növekedésükhöz és fejlődésükhöz, akkor ők maguk is jobb pozícióba kerülnek, nagyon hatással bírnak a környezetükre, mihelyst kikerülnek az iskolapadból. (Niman, 2014)

\subsubsection{Motiváció}

A motiváció az a folyamat, amelynek során egy jól meghatározott tevékenység elvégzése támogatott, irányított és hosszú távú jelleggel bír (Schunk, et al., 2008). A motivációs folyamatok magába foglalják a rövid- és hosszútávú célokat, a választás szabadságát, a szabad célválasztást, a kimenetellel és cselekedetekkel kapcsolatos elvárásokat, az önértékelést, a társadalmi összehasonlíthatóságot és a személyes hatékonyságot (Schunk \& Usher, 2012).

A célmeghatározás nemcsak a minél több szerzésében merül ki, hanem az akarat kifejtésében, hogy elérje a kitüzött célokat, valamint az önértékelés felállításában, mikor meghatározza az elérni kívánt célokat (Morrison \& DiSalvo, 2014). Ahogyan Scott Nicholson is rávilágít, ha a felhasználók maguk rendelkezhetnek a saját céljaik meghatározása felett, szorosabb kapcsolat fogja füzni őket az alkalmazáshoz, ily módon jelentőségteljesebb tartalmú eszköznek fogják tekinteni (Nicholson, 2012). 
A főként Richard M. Ryan és Edward L. Deci munkásságával fémjelzett öndeterminációs elmélet (avagy önrendelkezés elmélete, „Self-Determination Theory - SDT”) meghatározza azokat az alapvető pszichológiai szükségleteket, melyektől az egyén hatékonynak, motiváltnak érzi magát, pszichológiailag egészséges marad anélkül, hogy külső ráhatás vagy közbeavatkozás érné döntései közben. Ez a három szükséglet a kompetencia, a kötődés és az autonómia, melyek elengedhetetlenül szükségesek a növekedésre és integrálódásra irányuló természetes hajlam optimális müködésének elősegítéséhez, valamint a konstruktív szociális fejlődés és személyes jóllét biztosításához. (Ryan \& Deci, 2000)

Egy sikeresen gamifikált alkalmazásban a kihívásoknak illeszkedniük kell a játékos képességeihez, lehetőségeihez (Kenéz, 2015). Fromann szerint a kulcs a megfelelő terhelés, a jól meghatározott szintek és az ideális jutalomrendszer hármasában keresendő (Fromann, 2012). Ha a játékosok értelmes lehetőségek felett dönthetnek, azaz a játékos befolyással bír az esélyeire a játékban, akkor ez jelentős motivációnövekedést jelenthet, ami a hosszabb távú elköteleződés és bekapcsolódás feltétele. (Kenéz, 2015)

\subsubsection{Belső és külső motiváció szerepe}

Az öndeterminációs elmélet alapján Ryan és Deci a motiváció 3 típusát azonosította: amotiváció, külső motiváció és belső motiváció (2. ábra). (Ryan \& Deci, 2000)

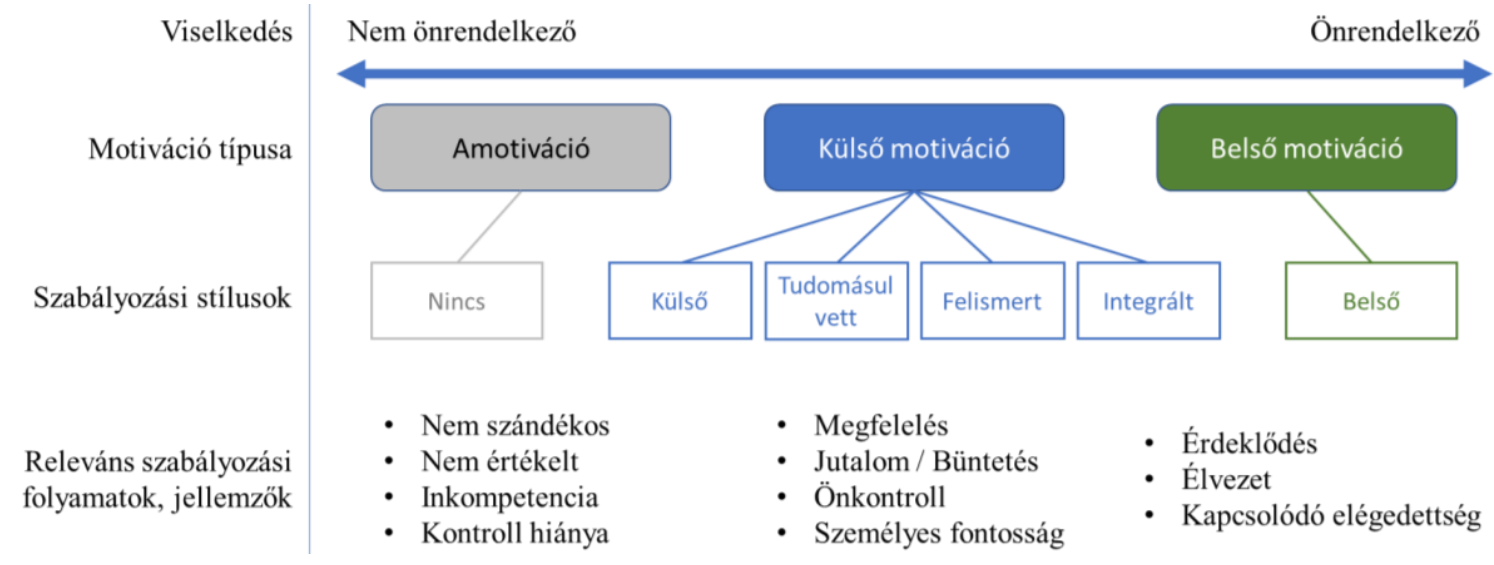

2. ábra: Az öndeterminációs elméletből levezetett 3 motivációtípus és szabályozásuk ( (Ryan \& Deci, 2000) alapján saját szerkesztés) 
Amotivált állapot esetén az egyénből teljesen hiányzik a cselekvésre hajlandóság (Pusztai, 2018), ilyenkor egyáltalán nem cselekszenek, vagy csak egyszerúen haladnak az árral. Akkor lehet jellemző, ha az alany nem tudja értékelni az adott tevékenységet, nem érzi magát kompetensnek az ügyben, vagy egy számára nem kedvező és/vagy lényegtelen kimenetelt eredményezne (Ryan \& Deci, 2000). Egy személy akkor tekinthető belsőleg motiváltnak, ha egy adott tevékenység elvégzését nem egy nyilvánvaló jutalom miatt teszi meg, hanem szimplán magáért a tevékenységért (Deci, 1972). Ilyenkor döntéseit az érdeklődés, a tevékenység élvezete, vagy annak kimeneteléhez kapcsolódó (várt) elégedettség vezeti, cselekvéseinek szabályozottsága pedig belső késztetésből származik (Ryan \& Deci, 2000). A külső motiváció egy olyan tevékenység teljesítményéért felel, melynek elvégzése külső jutalmazást von maga után (státusz, elismerés stb.) (Deci, 1972). A külső motiváció esetében 4-féle szabályozási stílust is elkülönít az elmélet, attól függően, hogy az alany mennyire fogadja be a szabályozást: külső reguláció; tudomásul veszi és betartja, ám nem érzi magának; az elvárt viselkedési cél megértésével és azzal egyetértésben követett szabályozás; valamint a teljesen elfogadott, saját értékeivel és elvárásaival is megegyező reguláció (Ryan \& Deci, 2000). Egy korábbi tanulmányában Edward L. Deci megállapította, hogy a külső megerősítés hatással bír a belső motivációra (Deci, 1971).

Az egyének kognitív értékeléssel kapcsolatos kísérletek és megfigyelések alapján elöfordulhat, hogy egy adott jutalmazási forma a belső motivációt külsővé alakítja, vagy a külsőt belső hajtóerővé alakítja. Ha egy rendszeresen végzett tevékenységért az alany elkezd pénzben kifejezett jutalmat kapni, akkor a tevékenységét „megrendelt szolgáltatásként” kezdheti el kezelni, ily módon annak további végzése a pénz juttatásától fog függeni (Deci, 1971), amit egy külső kontrolleszköznek fog vélni. Azonban, ha külső jutalmazásként interperszonális jutalomban (pl. szóbeli megerősítésben) részesül az alany, akkor a jutalom jelentéstechnikailag kevésbé megkülönböztethető az elégedettséggel összefüggő érzésekkel, ily módon az alany a tevékenységgel kapcsolatos pozitív érzete erősödik. Ennek folyományaképpen a szóbeli megerősítés további nyújtása nélkül is erősödhet a tevékenység elvégzésével kapcsolatos hajlam, ily módon erősödik az alany belső motivációja. (Deci, 1972)

A belső motiváció okait vizsgálta a Gamified UK és Motivait kezdeményezések gamification szakértője, Andrzej Marczewski is. Felállította a RAMP-modellt, mely a gamifikált rendszerekhez illesztve fogja össze az egyénben felkeltendő belső motiváció 4 
összetevőjét: kötődés (Relatedness), függetlenség (Autonomy), kiválóság (Mastery) és cél (Purpose) (Marczewski, 2013). A „kötődés” és a ,függetlenség” már megjelent Deci és Ryan öndeterminációs elméletében (SDT) is, a „kiválóság” pedig megfeleltethető az SDT „kompetencia” tényezőnek. A döntéshozatal körülményeit vizsgáló 3 összetevő mellett megjelenik negyedikként a döntéshozatal célja is, a cselekvés magasztosabb jelentése, milyen nagyobb ügyhöz járul hozzá a döntés meghozatala. (Pusztai, 2018)

Mind a belső, mind a külső kimenetelekkel kapcsolatos elvárások motiváló hatással bírhatnak. Alkalmazásspecifikus viszonylatban a belső motiváció eléréséhez a felhasználónak büszkeséget kell érezniük az elért eredményei kapcsán. A külső motivációt segíti, ha a felhasználó meg tudja mutatni, hogy legyőzte a játékot vagy sikeresen elért egy célt. Gamifikált szolgáltatások esetén a társadalmi összehasonlítás ösztönözheti az önértékelést. Azok, akik összehasonlítják magukat más játékosokkal, motiváltabbakká válhatnak és magasabb személyes hatékonyságot érhetnek el. A játékosok megoszthatják másokkal a pontjaikat, a gyüjtött jelvényeket vagy egy adott szint leküzdésének a tényét. (Morrison \& DiSalvo, 2014)

A nem megfelelően felállított szabályrendszer rejtheti magában azt a hátrányos következményt, miszerint a gamifikált alkalmazás által nyújtott külső késztetés csökkenti a belső motiváció mértékét (Nicholson, 2012). Ebből eredhet, hogy ha egyszer elkezdődött egy jutalmazási forma, akkor annak résztvevőit folyamatos jutalmazásban szükséges tartani (Zichermann \& Cunningham, 2011). Ahogyan Nicholson rámutat a tanulmányában (Nicholson, 2012), ha az adott téma iránt csökkentett érdeklődést tanúsít a résztvevő, a jutalmazás nem fogja visszafogni a belső motivációt, hiszen eleve alacsony volt ennek a szintje. A felhasználótól elvárt tevékenységgel össze nem függő külső jutalmazási formákat nehezen lehet integrálni és belső késztetéssé alakítani, mivel erős annak az érzete, hogy egy külső entitás akar az egyén viselkedésére hatást gyakorolni. Ha a felhasználó azonosulni tud olyan célokkal és csoportokkal, melyek ő számára jelentőségteljesek, akkor nagyobb a valószínüsége egy autonóm, internalizált viselkedés kialakítására, ugyanis a felhasználó össze tudja kapcsolni ezeket a célokat a már meglévő, saját céljaival (Nicholson, 2012). Az a felhasználó, aki a tevékenységet azonosítani tudja a saját céljaival és igényeivel, sokkal inkább látja pozitívnak azt az adott aktivitást, mintha külső kontroll használatát alkalmaznák (Deci \& Ryan, 2004). Nicholson kihangsúlyozza a felhasználó számára jelentőségteljes gamifikált rendszer építését, feltételezvén, hogy a rendszer 
célja a hosszútávú szisztematikus változtatás elérése, ahol a felhasználók pozitívan érzik magukat a nem játékszerü tevékenység során. A jelentőségteljes gamifikáció (avagy „meaningful gamification”) a szervezet igényei helyett a felhasználó céljaira helyezi a hangsúlyt. (Nicholson, 2012)

Werbach és Hunter kiemelik azt a lehetséges negatív kimenetelt, mely során az alkalmazás által generált külső motiváció „felfalhatja” a tevékenységhez kapcsolódó belső motivációt - vagyis elfeledtetheti azt az indokot, amivel eredetileg, a játék nélkül kapcsolódott a tevékenységhez (Werbach \& Hunter, 2012). Ily módon a játékosok döntései a játék logikájának fognak megfelelni, nem a valódi cél elvárásainak (Kenéz, 2015). Hasonló problémát eredményezhet az is, ha a játékban résztvevők a játékra hangolják rá a viselkedésüket, és kihasználják a játék lehetőségeit, akár visszaélve és kihasználva azokat. (Kenéz, 2015)

Ivo Blohm és Jan Marco Leimeister - felhasználva Jane McGonigal munkásságát (McGonigal, 2011) - négy pontban gyüjtötték össze, hogy egy IT-alapú, gamifikációval megtámogatott szolgáltatás miként tudja növelni a felhasználó belső motivációját, miközben az adott szolgáltatás fó célját nem befolyásolja (Blohm \& Leimeister, 2013):

- Felhasználói elégedettség növelése: Az egyén viselkedésének folyamatosan dokumentálása révén vizualizálhatóvá válik az előrehaladása, elősegíti a személyes célok lebontását, valamint azonnali visszajelzésre ad lehetőséget, így a felhasználókban magas szintủ egyéni teljesítmény érzetét tudja kelteni.

- Optimizmus továbbítása: A gamifikáció lehetőség teremt az önrendelkezésre, a felhasználó megtapasztalhatja az eredményesség érzetét, valamint a siker reményét.

- Társadalmi interakciók támogatása.

- Jelentés és értelem biztosítása: A felhasználók általában olyan problémák elé kerülnek, melyek túlmutatnak aktuális képességein, így megoldásukhoz önmaguk fejlesztése szükséges. 


\subsubsection{Viselkedés tényezői}

Különösen egy ügyfeleknek szánt gamifikált szolgáltatás esetében a szolgáltató célja, hogy a felhasználóik rendszeresen, szokássá alakulva visszatérjenek a folyamatukba legyen az vásárlás, nézelődés, tanulás vagy szimpla használat. Egy új szokás kialakításához egy új viselkedésminta elsajátítása szükségeltetik. (Pusztai, 2018)

A viselkedés véghezviteléhez szükséges tényezőket BJ Fogg egy háromösszetevős modellben foglalta össze, melyet „Fogg Viselkedésmodell”-ként (Fogg Behaviour Model FBM) neveztek el. A modell tényezői a motiváció, a képesség és egy kiváltó ok (avagy trigger-esemény). Azaz annak érdekében, hogy a megcélzott tevékenység megtörténjen, az alanynak elegendő motivációra, megfelelő mértékủ képességre és egy hatékony trigger-eseményre van szüksége (3. ábra), s ennek a hármasnak egy időpontban kell teljesülnie. (Fogg, 2009)

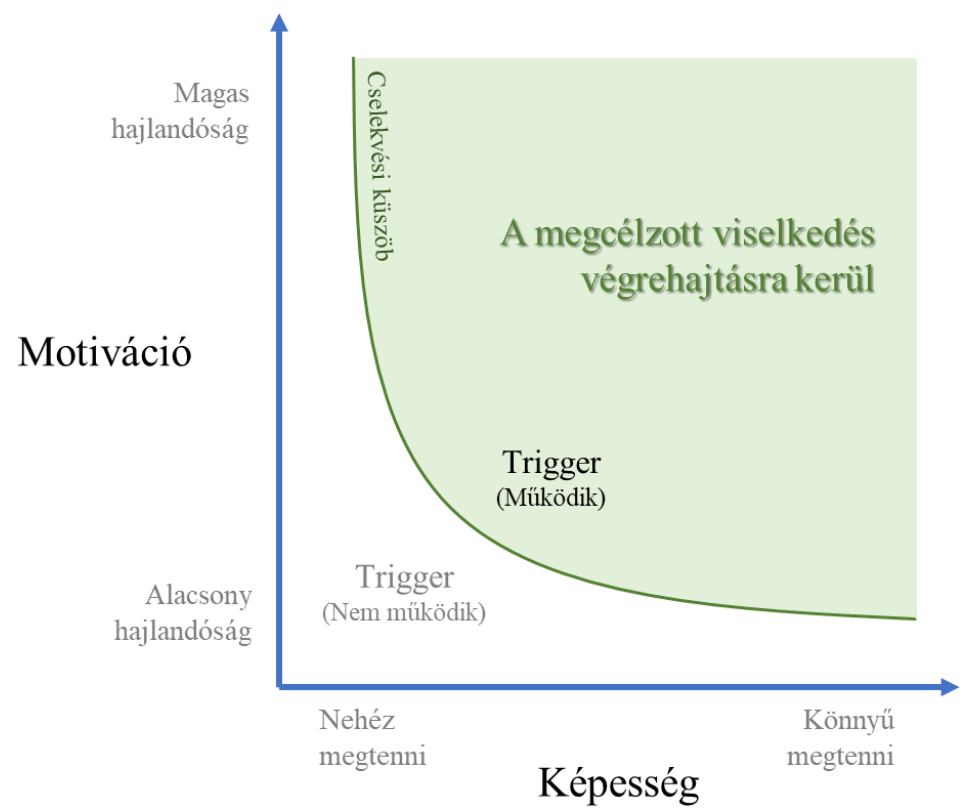

3. ábra: A FBM 3 tényezőjének kapcsolata ( (Fogg, 2009) és (Pusztai, 2018) alapján saját szerkesztés)

Fogg értelmezésében a motiváció három faktorból (motivátorból) áll, melyek egy-egy érem két oldalát takarják (Pusztai, 2018) (Fogg, 2009):

1. Élvezet keresése / Fájdalom elkerülése: A két tényező hatása azonnali. Kevés gondolkodást igényelnek, mert a biológiai szükségletekhez és a primitív ösztönökhöz kapcsolódnak. 
2. Remény keresése / Félelem elkerülése: Ez a tengely a kimenetellel kapcsolatos várakozást veszi alapul. Míg a remény a pozitív kimenetelben való bizakodást takarja, addig a félelem a negatív történések elkerülésében bízik.

3. Közösségi elfogadás keresése / Elutasítás elkerülése: A közösség általi befogadás, véleményalkotás miatti aggódás - eltérő mértékben - jelen van az emberek többségében.

A képesség azt a tudás-, energia-, időkapacitást takarja, mely az adott viselkedés elvégzéséhez szükséges. Annak érdekében, hogy ez minél kisebb korlátozó feltételt jelentsen, az elvárt viselkedéshez szükséges folyamat lépéseit minél jobban optimalizálni szükséges, eltávolítván a felesleges mozzanatokat és nehézségéket belőle (Pusztai, 2018). Fogg 6 tényezőt azonosított modelljével összefüggésben: feladat elvégzéséhez szükséges idő, ráfordítás pénzértéke, a szükséges fizikai erőfeszités nagysága, megkövetelt agymunka mértéke, mennyire fogadja el a közösség, valamint a rutintalanság, azaz mennyire különbözik az egyénben már meglévő szokásoktól (Fogg, 2009). Ha a triggertől eltekintünk, akkor a cselekvési készség akkor mutatkozik meg, amikor az egyén motivációjának és a képességének „összege” eléri a viselkedés cselekvési küszöbét. Munkám során a cselekvési küszöb azon minimálisan elegendő motiváció-képesség kombinációk összességét jelenti, melynél az egyén egy meghatározott trigger hatására már elvégzi a kívánt viselkedést.

A kiváltó ok többféle formát ölthet - lehet hangjelzés, szöveges üzenet, egy kereskedelmi felhívás, egy korgó gyomor stb. -, ám a hatékony viselkedéskiváltáshoz a trigger megfelelő időzítése is szükséges. Egy trigger akkor válik sikeressé, ha egyrészt az alany észreveszi azt, másrészt társítani tudja az elvárt cselekvéshez, harmadrészt rendelkezik a trigger időpontjában a megfelelő motivációval és képességgel (lehetőséggel), hogy a kívánt viselkedést véghez vigye. (Fogg, 2009)

\subsubsection{Szokás kialakítása}

Ha egy adott cselekvést, viselkedési mintát az egyén többször, rendszeresen (de nem feltétlen gyakran) megtesz, akkor cselekedete szokássá alakul, azaz olyan automatikus cselekedetté, melyet meghatározott szituációs elemek váltanak ki (Morsella, et al., 2008). A szokás egyfajta gondolkodásmódnak tekinthető, amely erősíti az egyénben a szokásokkal 
kapcsolatos útmutatások érzékelési készségét, valamint megakadályozza abban, hogy más, kevésbé hatékony cselekvési módokat sajátítson el (Verplanken \& Aarts, 2011). William James értelmezésében a szokás egy stabil, támogatott környezetben adott válaszok (jelen esetben viselkedési esetek) ismételt végrehajtására való hajlamot jelenti (James, 1890). Ahhoz, hogy egy nem gyakori cselekedet szokássá fejlődjön, az egyénnek magasfokú hasznosságot kell tudnia elkönyvelni, legyen az akár élvezeti érték vagy fájdalomelkerülés. Amennyiben viszont egy adott cselekedet nem nyújt nagy hasznosságot, ám elvégzése egyszerü (energiabefektetése alacsony és könnyü hozzáférésű), szintén szokássá fejlődhet (Eyal, 2014). Ily módon a szokás 2 tényező kombinációjából adódik: a gyakoriság és a hasznosság. Az utóbbi esetében előfordul a szakirodalomban, hogy helyette inkább az elégedettséget említik (Limayem, et al., 2007), és különösen online szolgáltatások esetén eme elégedettséget tekintik a folyamatos használat (avagy szokás) kulcstényezőjének (Tran \& Huynh, 2015). A két tényező szokásra gyakorolt hatását tekintve egy lényeges különbség figyelhető meg, mégpedig az, hogy míg gyakori használat mellett a nulla hasznosságú tevékenységből is válhat szokás, addig hiába bír kimagasló észlelt hasznosággal (avagy elégedettséggel) egy másikfajta viselkedés, el kell érnie egy minimális ismétlésszámot ahhoz, hogy szokásnak lehessen tekinteni (Eyal, 2014).

Nir Eyal kidolgozott egy módszert, amit termékfejlesztésekben alkalmazva segíthet a felhasználó szokásformálásban. Egy olyan terméktervezési „keretrendszer”, mely hosszútávú elkötelezettségen alapulva segíti kielégíteni a felhasználó igényét (Eyal, 2014). Ezt

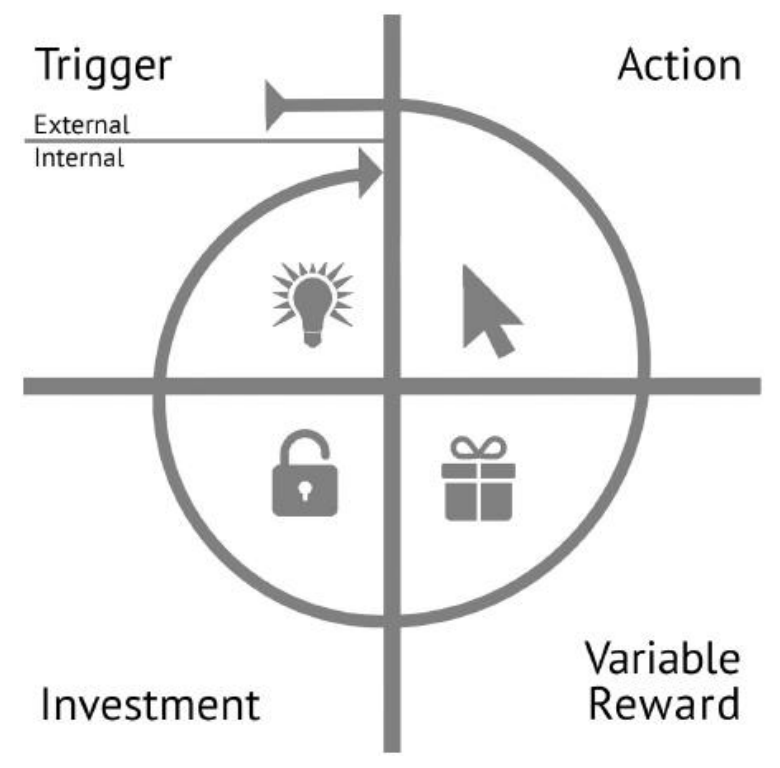

4. ábra: Eyal-féle horogmodell (Eyal, 2014) 
a módszert nevezte Horog-modellnek (4. ábra). Az egyén szokásformálása tervezői oldalról egy külső Kiváltó ok (Trigger) alkalmazásával indul el, és ha a felhasználó elkezdi egyre többször használni a terméket, akkor ez belső triggerré alakul. Ha a kiváltó ok hatásosnak bizonyul, a felhasználó az ígért vagy elképzelt kimenetel reményében elvégzi az Akciót (Action). Az elvégzett tevékenységért jár az elismerés, ám Eyal külön kihangsúlyozza a Változó Jutalmakat (Variable Reward). A modell különlegessége a ciklus 4. lépése, a Befektetés, azaz szándékosan plusz ráfordítást követelünk meg a felhasználótól, legyen az idő, adat, erőfeszítés, szociális tőke vagy pénz. Ez a fajta befektetés a termék/szolgáltatás fejlesztéséhez, fejlődéséhez járul hozzá, annak használati javításához tesz hozzá, így javarészt nem vagyoni befektetést takar. Ilyen ráfordítás lehet például a preferenciák beállítása, a termék egyes képességeivel való megismerkedés, barátok meghívása a szolgáltatásba stb. Ezektől maga a használat válik könnyebbé, folyamatosabbá, hatásosabbá vagy személyesebbé, ami miatt a felhasználó már a maga által kreált trigger miatt tér vissza újra. (Eyal, 2014)

\subsubsection{A „flow” élmény}

Előfordulnak olyan esetek, amikor az ember olyannyira belemerül az általa végzett tevékenységbe (legyen az munka, sport vagy müvészet), hogy önkéntelenül is hajlamos a világ ingereit egy időre figyelmen kívül hagyni (Csíkszentmihályi, 2001). Ez az élmény az elmének egy olyan müködési állapota, melynek során a belemerülése, a tevékenység mély

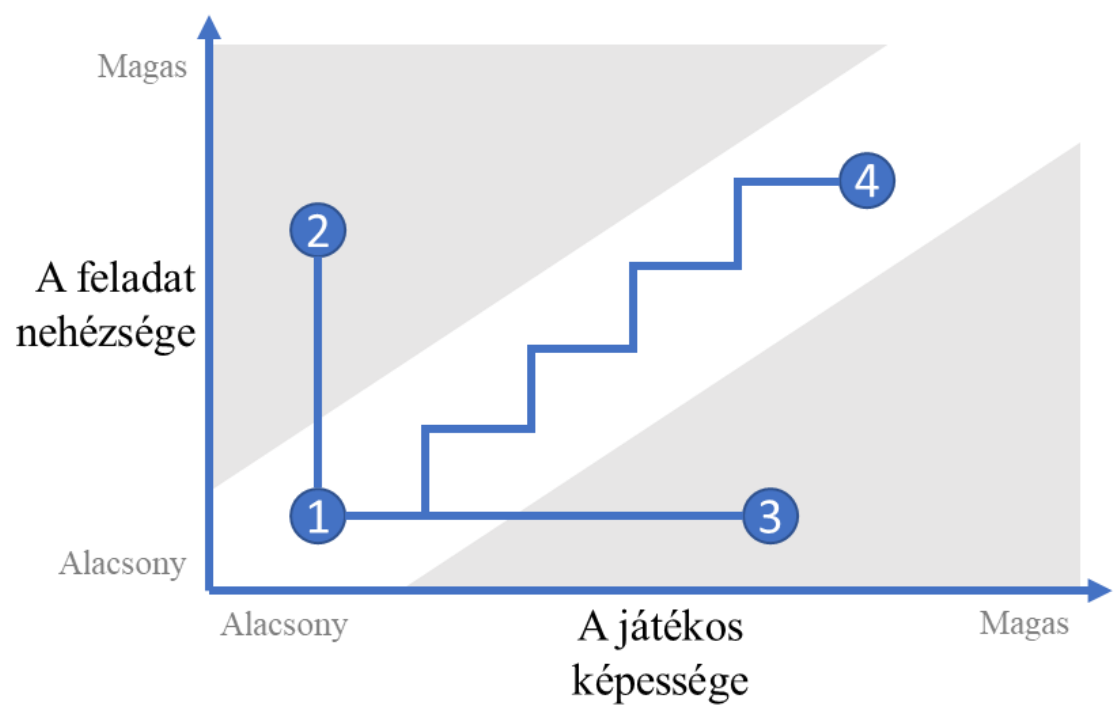

5. ábra: A „Flow”-élmény fenntartása ( (Pusztai, 2018) alapján saját szerkesztés) 
végzése örömmel tölti fel az egyént, és késztetést érez annak folytatására (Mérő, 2010). Csíkszentmihályi Mihály ezt az élményt nevezte el áramlatélménynek, avagy „flow”-nak. A gamifikáció tekintetében ez az elmélet párba állítja az egyén képességét az elvégzendő feladat nehézségével (5. ábra). A két tényező egyenletes növelése járul hozzá az áramlatélmény fenntartásához. Ha egy gamifikált folyamat során ugyanolyan szintü akadályokat kell leküzdenie az egyénnek (1) $\rightarrow$ (2)), úgy egyrészt gyakorlottá válik, ám képessége nem fog nőni, a folyamat rutinfeladatokká fog válni, s végül a játékos elveszti érdeklődését. Ha a feladatok gyorsan nehezednek, ám a játékos képessége nem fejlődik ennek megfelelően, frusztráltság alakul ki, és a sikertelenség és bukás érzésével idő előtt félbe hagyja a folyamatot $($ (1) $\rightarrow$ (3)). A két eshetőség között húzódik egy „csatorna”, melyben az egyén a saját aktuális képességét követő, egyre nehezedő akadályok állnak, melyek leküzdésével nő az egyén képessége, ez biztosítja a „flow”-élmény fenntartását (1) $\rightarrow$ (4)). (Pusztai, 2018)

\subsubsection{Munkahelyi motiváció, légkör és jóllét}

Bizonyos vélekedések szerint a munkahelyi teljesítmény a motiváció és a képesség szorzataként tevődik össze, azaz kellő motiváltság nélkül nem várható kimagasló teljesítmény a munkavállalók részéről (Farkas, et al., 2013). Mathe és társai által készített 2011-es tanulmányukban (Mathe, et al., 2011) megfogalmazták a munkahelyi környezetre alkalmazható 9M motivációs modellt, mely az alábbi elemekből épül fel:

- Munkahelyi környezet

- Munka- és szerződéses feltételek

- Munka és magánélet egyensúlya

- Minőségi munka és fejlődés

- Megbecsülés és ösztönzés
- Mérhető célok és visszajelzés

- Misszió és jövőkép

- Megosztott értékek és kultúra

- Munkahelyi kapcsolatok

Farkas és szerzőtársai által készített 2013-as felmérés szerint - mely a magyarországi munkavállalók motivációs tényezőinek prioritásait vizsgálta a 9M motivációs modell alapján felállított, 9 kategóriába sorolt 37 tényező segítségével - megfigyelték azt a trendet, miszerint egyre inkább előtérbe helyeződnek a biztonsággal, a stabilitással, a jó munkahelyi légkörrel és a megfelelő kapcsolatokkal összeköthető munkahelyi motivációs tényezők (Farkas, et al., 2013). A kutatásból kiderül, hogy a munkavállalók körében a 
legfontosabb motivációs tényezőként a „Megfelelő munkahelyi légkör és bánásmód” jelentkezik, és ötödikként (a 37-elemü listában) a „Megfelelő munkatársi kapcsolatok, jó munkahelyi csapat” szerepel (6. ábra).

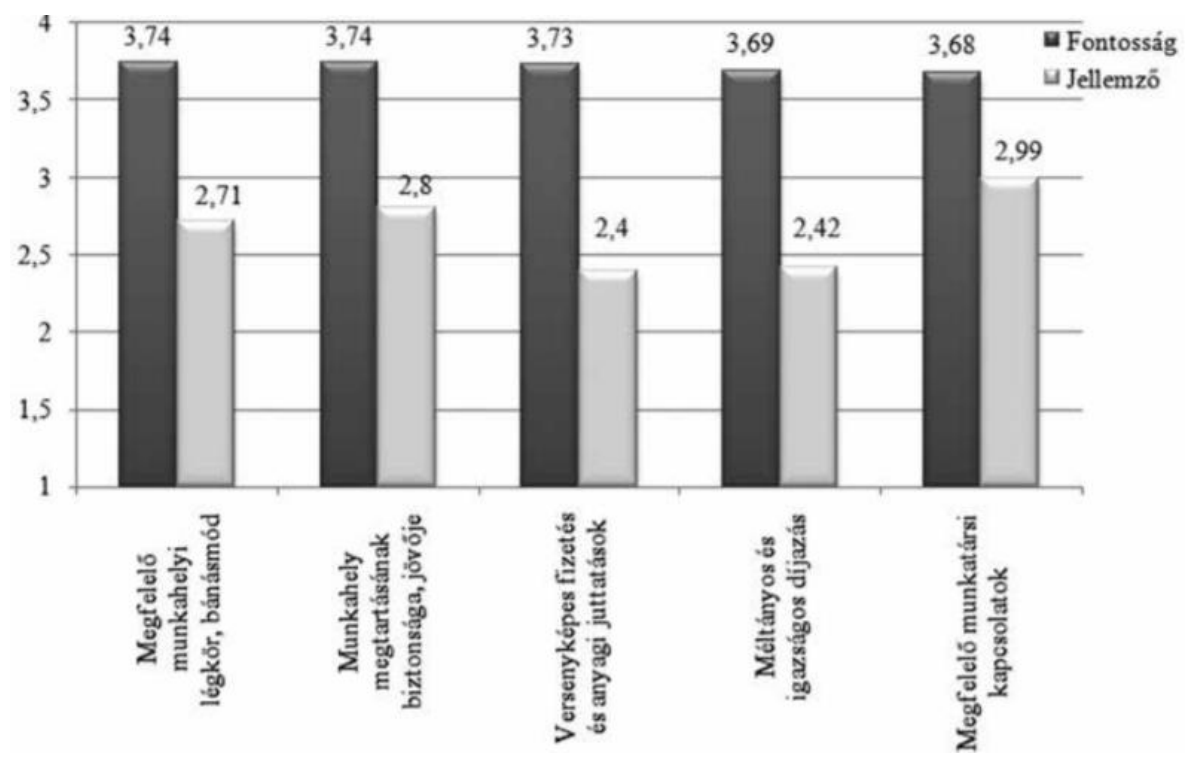

* 1-től 4-ig terjedő skálán, ahol a 4 jelenti, hogy nagyon fontos, míg az 1 jelenti, hogy egyáltalán nem fontos.

** 1-től 4-ig terjedő skálán, ahol a 4 jelenti, hogy nagyon jellemző, míg az 1 jelenti, hogy egyáltalán nem jellemző.

6. ábra: Az 5 legfontosabb motivációs tényezők fontossága* és jellemző** jelenléte a munkahelyen (Farkas, et al., 2013)

A tényezők kategóriáit tekintve, melyek megfelelnek a fentebb említett $9 \mathrm{M}$ motivációs modell elemeinek, a „Munkahelyi környezet” harmadikként, a „Munkahelyi kapcsolatok” pedig a negyedik legfontosabbként szerepel (Farkas, et al., 2013).

Több tanulmány által bizonyított tény (Kiss \& András, 2018; Taylor, et al., 1985; Asztalos, et al., 2012), miszerint a sport és a testedzés, mint viselkedés már önmagában hatékony stressz-csökkentő hatással bír. A rendszeres testedzésnek természetes hozadéka az életminőség szubjektív megítélése, azaz a jóllét javulása, amelynek szervezeti következménye a hiányzások számának csökkenése, a csökkenő kilépési arány, a megnövekedett teljesítmény, valamint a baleseti ráta csökkenése (Houtman, et al., 2007).

\subsubsection{Munkahelyi elköteleződés}

A munkavállalók cég iránti elköteleződése alapvető az üzleti vállalkozások sikeréhez. Az elköteleződés, elkötelezettség nem új fogalom, a kétezres évek elejétől pedig egyre 
gyakrabban használt kifejezéssé vált az emberi erőforrással foglalkozó szakemberek körében (Barna \& Fodor, 2018b). A csapathoz való tartozás, a kooperáció, a munkatársak közötti személyes kapcsolat kialakulása, a közösséghez való tartozás érzete vagy éppen ellenkezőleg, a személytelen és antiszociális környezet mind erősen befolyásolják az elkötelezettség szintjét (Szabó, 2016).

A munkavállalói elkötelezettség alatt a munkavállalók azon hajlandóságát és képességét értjük, mely hozzájárul a vállalati sikerhez. Az elkötelezettség annak a mértéke, hogy a munkavállalók önszántukból mennyi extra erőfeszítést, energiát, kreativitást és szenvedélyt hajlandóak beletenni a munkájukba (Perrin, 2008). A munkavállalói elkötelezettség pozitívumai közé sorolható - a munkáltató szempontjából vizsgálva - a nagyobb megtartási arány, a csökkent hiányzás, a vállalati célok és stratégia jobb megértése és elsajátítása. Ezen túlmenően Harter és szerzőtársai munkájukban rámutattak arra is, hogy a munkavállalói elköteleződés és a pénzügyi eredmény között közvetlen kapcsolat áll fenn (Harter, et al., 2002). Gallup 2013-ban közölt kutatásaiból (Sorenson \& Garman, 2013) kiderül, hogy a munkavállalók elköteleződésének hiánya az Egyesült Államoknak évente körülbelül 450-550 milliárd dollárba kerülhet. Ezzel a ténnyel összhangban áll, hogy a vállalatok törekszenek az elkötelezettség mértékének növelésére (Shuck \& Rose, 2013), és a menedzsment által a munkavállalói elköteleződés kialakításának kiemelt prioritásként való kezelésére (Shuck \& Wollard, 2010) (Schaufeli, 2012).

A munkavállalók elköteleződésének vizsgálatával számos cég foglalkozik, mint például az Aon szakértő-tanácsadó cég, akik évente jelentetik meg a témával kapcsolatos felméréseik eredményét. 2017-re vonatkozó vizsgálatuk szerint (Aon, 2018) a világon a munkavállalók 65\%-a érezte elkötelezettnek magát a munkáltatóhoz, európai viszonylatban viszont csak 60\% volt ez az érték. A 2016-os 2\%-os visszaeséstől eltekintve 2012-től folyamatosnak tekinthető az elköteleződés mértékének növekedése (7. ábra). 


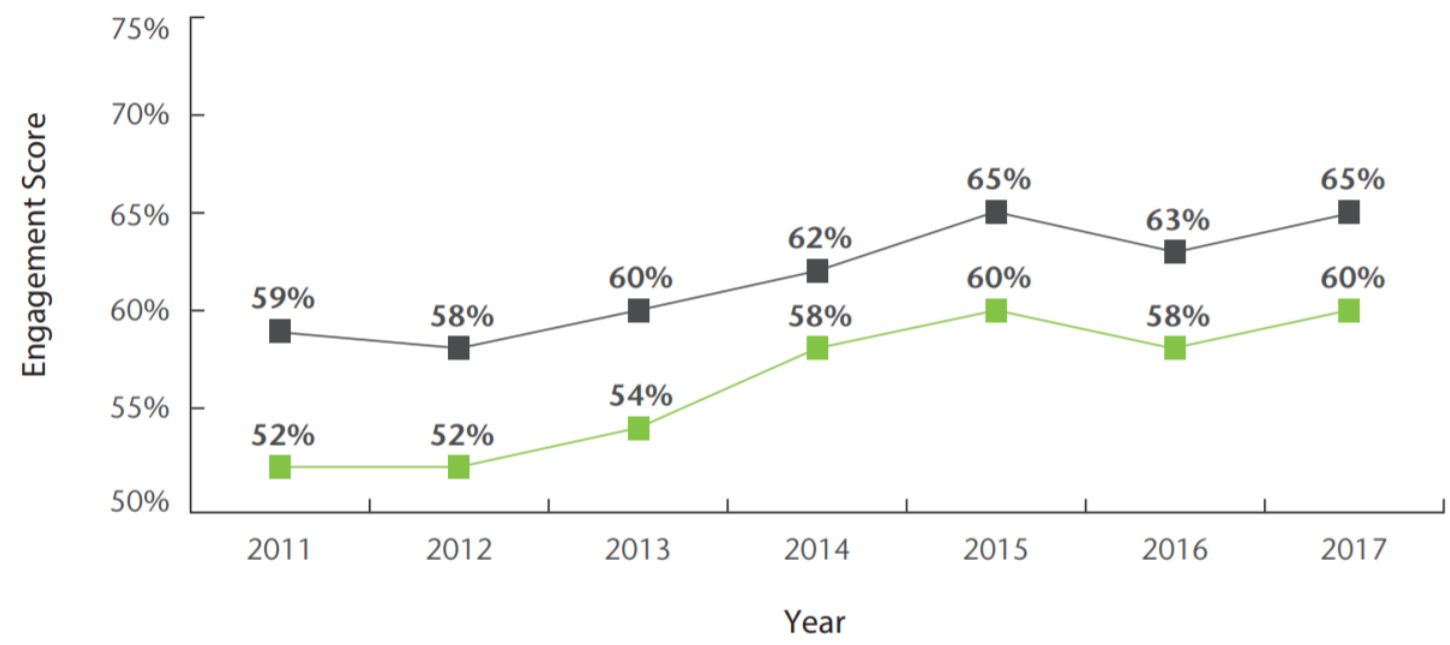

7. ábra: Munkavállalói elköteleződés világi és európai szinten (Aon, 2018)

2019-ben az Aonnal együttműködve a Kincentric cég folytatta a felméréseket, s eredményeik alapján világszinten egyszázalékos növekedéssel 66\%-os eredményt ért el, míg Európában (főként a Brexit problémával küzdő Egyesült Királyság visszaesése miatt) $60 \%$ on stagnált az elköteleződés mértéke (Oehler \& Adair, 2019).

A vállalatok számára lényeges, hogy megismerjék és tudatosítsák azokat a tényezőket, amik az elkötelezettség kialakulásában kulcsszerepet játszanak, tisztában legyenek azokkal a mozgatórugókkal, amik elköteleződésre késztetik a munkavállalókat a szakmájuk vagy a szervezetük iránt (Barna \& Fodor, 2018b). A különböző csoportosításokat összevetve Szabó Anna a munkásságában kilenc kategóriába sorolta az elkötelezettség növelésében szerepet játszó tényezőket (Szabó, 2016):

- Jövőkép

- Lehetőségek

- Munka és feladatok

- Önrendelkezés

- Szociális környezet
- Kommunikáció

- Környezet

- Vállalati értékek és gyakorlatok

- Javadalmazás és elismerés

A csoportosítás alapján kivehető, hogy minden olyan tényező, ami kapcsolatban áll a munkahelyi tapasztalatokkal, élményekkel, munkával és munkatársakkal, az az elkötelezettség egyik mozgatórugója, hajtóereje lehet. Az egyes tényezők hatása azonban az egyének igényei és szükségletei alapján eltérőek lehetnek. (Szabó, 2016) 
A szakirodalomban több esettanulmány is foglalkozik azzal, hogy a gamifikáció eszközeinek segítségével miként próbálták a munkavállalók, illetve a vásárlók elköteleződését növelni, mint például Jay-Z Decoded (Droga5, 2011), My Marriott Hotels (Robson, et al., 2015), vagy az SAP „Lead-in-one” és „Seeds” projektjei (Clark, 2011). Az esettanulmányok tapasztalatai alapján is elmondhatóak, hogy ezek közül csak azok lettek sikeresek, ahol a megfelelő gamifikációs dinamizmusok segítségével az alkalmazottak, illetve a vásárlók különböző játékostípusait tudták motiválni, hiszen megfelelő dinamikák és érzelmi reakciók hiányában a játékosok egyszerűen „elugranak” (Robson, et al., 2015).

\subsection{Játékostípusok}

Az ESA (Entertainment Software Association) által készített tanulmányok szerint (ESA, 2016) (ESA, 2019) 2016-ban az Egyesült Államokban a háztartások 63\%-ában legalább egy személy rendszeresen (hetente legalább 3 órát) játszott, míg 2019-ben 75\%-ra nőtt ez az érték. 2016-ban az átlagos játékos 35 éves volt, és legalább 13 éve játszott rendszeresen valamilyen számítógépes játékkal, míg 2019-ben az átlagos játékos 33 éves és 14 éve játszik. A nemek arányában nincs számottevő különbség, ugyanis már 2016-ban a játékosok 41\%-át a nők tették ki, 2019-ben már a 46\%-át. (ESA, 2016) (ESA, 2019).

Az eNET Internetkutató és Tanácsadó Kft. által 2017-ben végzett kutatás (eNet, 2018) szerint Magyarországon megközelítöleg 3,7 millió ember játszik videojátékkal, mely a felnőtt lakosság 58\%-át takarja. A felmérés alapján a férfiak $61 \%$-a és a nők 54\%-a szokott játszani, a legtöbb játékost pedig a 18 és 25 év közötti korosztály adja. A magyarországi videojáték piacának mértéke - amely magába foglalja a videojáték-vásárlást, a játékon belüli tranzakciókat, valamint a játékokhoz szükséges hardver és periféria vásárlását - 28 milliárd forintot tesz ki, mely megközelíti a 2006-os teljes hazai online kiskereskedelmi forgalmat (eNet, 2018), 2018-ban viszont (a márkázott ajándéktárgyak is beleszámítva) már 41 milliárdra rúgott a piac nagysága (Portfólió, 2019). 
A JátékosLét Kutatóközpont berkein belül Dr. Fromann Richárd évente készít felmérést a magyar játékosok körében. A 2017-es kutatásból kiderül (Fromann, 2018a), hogy a kitöltők $\left(\mathrm{N}=8528^{5}\right)$ körében közel azonos arányt képviselnek az egyedülállók (47,5\%) és a kapcsolatban élök (52,5\%), valamint szintén közel egyenlő arányban szerepelnek a tanulók (48,6\%) és a dolgozók (51,4\%). A 8. ábra látható videojátékhasználat-gyakoriságot tekintve állítható, hogy a válaszadók 96,5\%-a hetente legalább 1x játszik, a sokaság közel fele pedig mindennap (Fromann, 2018b).

\begin{tabular}{lcc} 
évi $1-2$ alkalom & 12 & $0.1 \%$ \\
\hline $2-3$ havonta & 41 & $0.5 \%$ \\
\hline havonta & 72 & $0.8 \%$ \\
\hline $2-3$ hetente & 170 & $6.3 \%$ \\
\hline hetente & 535 & $41.1 \%$ \\
\hline hetente többször & 3506 & $49.1 \%$ \\
\hline minden nap & 4183 & $0.1 \%$ \\
\hline SOHA nem játszom videojátékkal & 9 & \\
\hline Összes válasz & 8528 & \\
\hline
\end{tabular}

8. ábra: Videojátékok használatának gyakorisága (Fromann, 2018b)

A motivációjukat tekintve a többség számára lényeges szempont a játék során, hogy kalandokat éljen meg $(92,8 \%)$, próbára tegye magát $(91,8 \%)$, egy fantázia világba kerüljön (74,3\%), és egy csapat tagja legyen (72,3\%), amin belül hasznosnak érzi magát (87,2\%), viszont kevésbé keresi a harcot $(25,8 \%)$ és mások karaktereinek teljes mértékü megsemmisítését (13,9\%), s nem a hírnevet keresik benne (22,1\%) (Fromann, 2018c).

Számos személyiség- és játékostípus-modellt alkottak meg, mint például a Myers-Briggs Típusindikátort (MBTI) (Briggs Myers, et al., 1985), a Big Five modellt (amire Fivefactor / OCEAN / CANOE modellként is szokás hivatkozni) (Goldberg, 1993), a Bartleféle játékoskategorizálást (Bartle, 1993) vagy a BrainHex hét játékostípus modelljét (Nacke, et al., 2011). Hamari és Tuunanen összegyüjtötte a főbb modellalkotásokat, melyek főként a játékvilágban mért viselkedéstípusokat különböztetik meg (Hamari \& Tuunanen, 2014). A lista átiratát, valamint néhány elemmel történő kibővítését foglalja össze az 1. táblázat:

\footnotetext{
${ }^{5}$ A 2017-es JátékosLét kutatás mintaállománya közel 10x-ese az eNet kutatásénak, ám a minta reprezentatív jellege nincs megerősítve, szemben az eNet felmérésével.
} 


\begin{tabular}{|c|c|c|c|}
\hline Szerző(k) & Év & Kutatás alapja & Típusok / Dimenziók \\
\hline Briggs Myers & 1985 & $\begin{array}{l}\text { Viselkedés } \\
\text { Pszichográfia }\end{array}$ & $\begin{array}{l}\text { Extravertált/Introvertált, Érzékelő/Intu- } \\
\text { itív, Gondolkodó/Érző, Megítélő/Ész- } \\
\text { lelő dimenziók mentén } 16 \text { kategória }\end{array}$ \\
\hline Goldberg & 1993 & Pszichográfia & $\begin{array}{l}\text { Extraverzió, Barátságosság, Lelkiisme- } \\
\text { retesség, Érzelmi stabilitás, Nyitottság }\end{array}$ \\
\hline Bartle & 1996 & Viselkedés & $\begin{array}{l}\text { Teljesítő, Felfedezö, Társasági, Gyil- } \\
\text { kos }\end{array}$ \\
\hline Lazzaro & 2004 & Viselkedés & $\begin{array}{l}\text { Könnyű szórakozás, Nehéz szórakozás, } \\
\text { Módosított állapotok, Emberi faktor }\end{array}$ \\
\hline Whang Chang & 2004 & Pszichográfia & $\begin{array}{l}\text { Egyénorientált, Közösségorientált, Va- } \\
\text { lós világon kívüli }\end{array}$ \\
\hline Ip Jacobs & 2005 & Viselkedés & Megrögzött, Alkalmi \\
\hline Williams et al. & 2006 & $\begin{array}{l}\text { Játékon belüli de- } \\
\text { mográfia }\end{array}$ & $\begin{array}{l}\text { Csoportközéppont, Céh mérete, Szer- } \\
\text { vertípus, Frakció }\end{array}$ \\
\hline Yee & $\begin{array}{l}2006, \\
2007, \\
2012\end{array}$ & Pszichográfia & $\begin{array}{l}\text { Teljesítmény, Közösség, Elmélyülés } \\
\text { (+altípusok) }\end{array}$ \\
\hline Drachen et al. & 2009 & Viselkedés & Veterán, Megoldó, Pacifista, Küldönc \\
\hline $\begin{array}{l}\text { Hamari \& } \\
\text { Lehdonvirta }\end{array}$ & 2010 & Viselkedés & Pl. karakterszintek, osztályok \\
\hline Zackariasson et al. & 2010 & Pszichográfia & $\begin{array}{l}\text { Előrelépés és provokáció, Erő és ura- } \\
\text { lom, Segítés és támogatás, Barátok és } \\
\text { együttmúködés, Felfedezés és fantázia, } \\
\text { Sztori és eszkapizmus }\end{array}$ \\
\hline Kallio et al. & 2011 & Viselkedés & $\begin{array}{l}\text { Közösségi mentalista, Alkalmi menta- } \\
\text { lista, Elkötelezett mentalista }\end{array}$ \\
\hline Nacke et al. & 2011 & Neurobiológia & $\begin{array}{l}\text { Teljesítő, Túlélö, Felfedező, Társasági, } \\
\text { Vakmerő, Lángész, Győztes }\end{array}$ \\
\hline Stewart & 2011 & $\begin{array}{l}\text { Viselkedés } \\
\text { Pszichográfia }\end{array}$ & $\begin{array}{l}\text { Oltalmazó / Teljesítő, Racionális / Fel- } \\
\text { fedezö, Idealista / Társasági, Mester- } \\
\text { ember / Gyilkos, Uralkodó, Vándor, } \\
\text { Menedzser, Résztvevő, Megrögzött, } \\
\text { Alkalmi }\end{array}$ \\
\hline $\begin{array}{l}\text { Rab Árpád Szö- } \\
\text { rény }\end{array}$ & 2015 & Viselkedés & $\begin{array}{l}\text { Kalandozó, Gladiátor, Mágus, Bárd, } \\
\text { Kósza }\end{array}$ \\
\hline
\end{tabular}

1. táblázat: Személyiség- és játékostípusok vizsgálatával foglalkozó kutatások

( (Hamari \& Tuunanen, 2014) alapján kiegészítve (Saját szerkesztés))

A továbbiakban néhány személyiségmodellt jár körül a dolgozat.

\subsubsection{Myers-Briggs-féle Típusindikátor (MBTI)}

A módszer kidolgozása mögött Katherine Briggs és lánya, Isabell Briggs Myers áll, akik C. G. Jung tipológiai elméletét (Jung, 2006) ültették a mindennapokba. Jung három bipoláris dimenzió mentén állított fel preferenciapárokat: introverzió-extraverzió, érzékelés- 
intuíció és gondolkodás-érzelem. A Myers-Briggs modell egy újabb dimenzióval egészült ki, így alakította ki a négy preferenciapárból álló rendszerét (2. táblázat).

\begin{tabular}{|l|c|}
\hline \multicolumn{1}{|c|}{ Elküiönítés alapja } & MBTI preferenciapár \\
\hline $\begin{array}{l}\text { A személy külvilághoz való viszonyu- } \\
\text { lása (Honnan szerzi az energiáját?) }\end{array}$ & extravertált (E) - introvertált (I) \\
\hline Információgyüjtés, észlelés jellemzői & érzékelő (S) - intuitív (N) \\
\hline Döntéshozatal módja & gondolkodó (T) - érző (F) \\
\hline $\begin{array}{l}\text { Életstílus, a külvilágban való eligazo- } \\
\text { dás jellemzői }\end{array}$ & megítélő (J) - észlelő (P) \\
\hline
\end{tabular}

2. táblázat: MBTI preferenciapárjai (Mészáros, 2014) alapján

Egy-egy személyiség esetén általában a párok egyik tagja a meghatározóak, ám a dominancia mértéke változó. A négy preferenciapár egyes elemei alkotják a „típust” (pl. introvertált-intuitív-érző-megítélő=INFJ), melynek összesen 16 különböző kombinációja lehetséges. Ahogyan a Jobbágy-Takács szerzőpáros is rámutat, igazán tiszta típus nem létezik (Jobbágy \& Takács, 1997), valamint a preferenciák az évek során változhatnak, módosulhatnak a túlélés és a siker érdekében; erejük és minőségük a különböző életszakaszokban és szituációkban különbözőek lehetnek. (Mészáros, 2014)

\subsubsection{Bartle-féle játékostípusok}

Richard Bartle kutatása alapján a játékosok játékstílusuk, motivációjuk, magatartásuk és preferenciáik alapján négy csoportba sorolhatóak: gyilkosok (Killers), felfedezők (Explorers), társaságiak (Socializers) és teljesítők (Achievers) (Fromann, 2012). A modellt a 9. ábra szemlélteti.

A csoportosítás két dimenziója a cselekvés-kapcsolat és a játékos-világ tengelyén terül el, melyek a játékosok érdeklödését mutatják. A Teljesitők közé azok a játékosok sorolandóak, akik az eredményességre törekszenek, és céljuk az akadály leküzdése vagy mások elismerésének kivívása. A Felfedezők szeretik a határokat feszegetni, és igyekeznek a lehető legtöbbet kihozni az adott játékból, felmérni annak határait és bejárni minden szegletét. Legfőbb motivációjuk a játékterep feltérképezése és mások megismerése. A Társaságiak számára a lényeges szempont a másokkal való kapcsolattartás és ismerkedés, leginkább a többi résztvevő miatt vannak jelen, gyakran használják a játékok chat funkcióit. A Gyilkosok hajlandóak nem szimpatikus magatartásmintát felvenni a játék során: 
elsődlegesen a károkozásra, vagy a mások játékból való kiiktatására törekszenek, céljuk a ranglista élére kerülni. (Barna \& Fodor, 2018b)

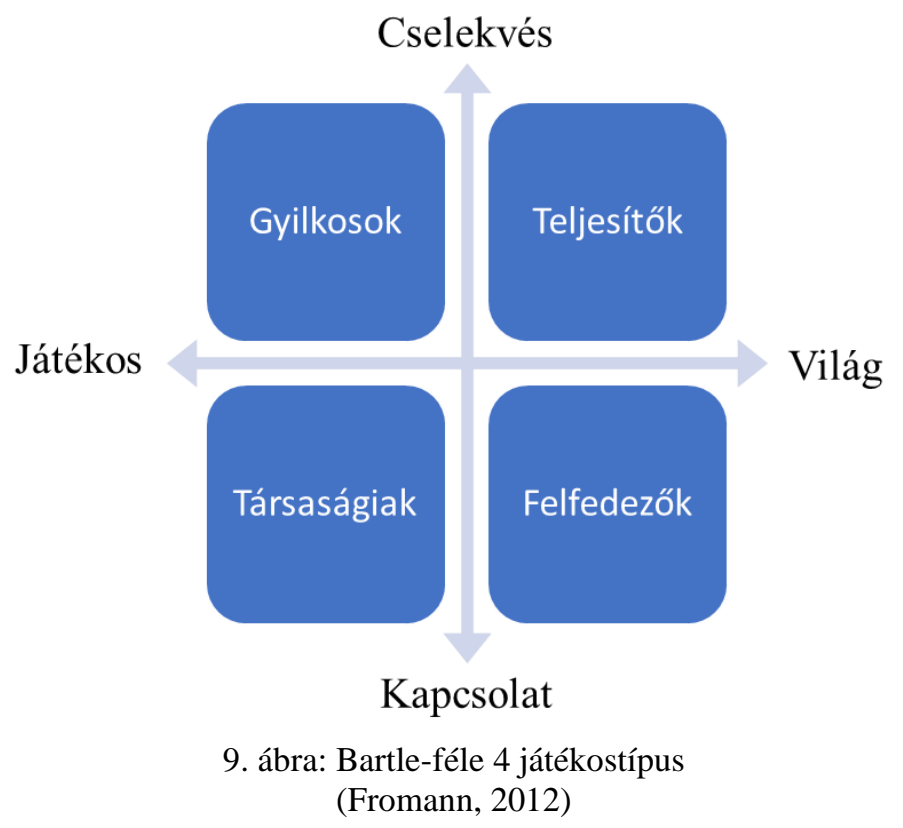

Nick Yee (Yee, 2006) és Dan Dixon (Dixon, 2011) is rávilágított a tanulmányukban, hogy a Bartle-féle modell nem feltétlenül létezik ennyire letisztult formában. Egy felhasználó többféle magatartást is tanúsíthat játék közben, átfedést eredményezve a kategóriák között, így azok nem kölcsönösen kizáróak. Bartle - felismerve modellje korlátozottságát 2003-ban bevezette az implicit/explicit dimenziót, megduplázva ily módon a kategóriákat (Gyilkos $\rightarrow$ Romboló (Im) + Politikus (Ex); Teljesitő $\rightarrow$ Megalkuvó (Im) + Tervező (Ex); Társasági $\rightarrow$ Barát (Im) + Kapcsolatépítő (Ex); Felfedező $\rightarrow$ Hacker (Im) + Tudós (Ex)) (Bartle, 2003).

\subsubsection{BrainHex modell}

A BrainHex modell tipológiája az egyének játékviselkedési preferenciáit kívánja bemutatni a korábbi viselkedéstípusokról szóló tanulmányok, neurobiológiai kutatások, játékmódok értékezésével és a játszás során tapasztalható érzelmek ötvözésével. A modell által meghatározott kategóriákat egy egyén nem kizárólagosan birtokolja, hanem csak az egyén alaptípusát mutatja meg, ám az egyén teljes viselkedése a kategóriák különbözö mértékü kombinációjából tevődik össze (Nacke, et al., 2014) (Busch, et al., 2016) (Oliveira, et al., 2017). A tipológia 7 alaptípust határozott meg: Felfedező, Túlélő, Vakmerő, Lángész, Győztes, Társasági és Teljesítő (10. ábra): 
Felfedező (Seeker): Érdeklődés és kíváncsiság vezérli (Busch, et al., 2016). Az agy érzékelési kérgét és a memória asszociációs területét érinti leginkább (Nacke, et al., 2014). A Felfedező kíváncsi a játék világára, megcsodálja az adott pillanatot (Nacke, et al., 2014), örömmel fedez fel furcsa dolgokat és keres hasonlóságokat, valamint szereti stimulálni az érzékeit (BrainHexBlog, 2008).

Túlélő (Survivor): A félelem, az ijesztő körülmények, a kockázatos helyzetek kedvelője, melyek leküzdéséből és az azt követő újbóli

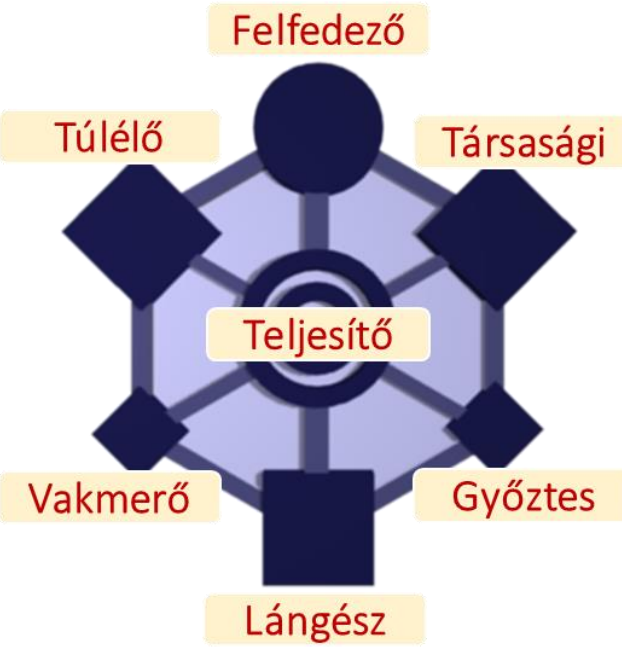

10. ábra: A BrainHex-modell alaptípusai ( (BrainHexBlog, 2008) és (Oliveira, et al., 2017) alapján saját szerkesztés) biztonságérzetéböl nyer örömöt (BrainHexBlog, 2008). Míg önmagában a rettegés egy erősen negatív élményt takar, a Túlélők bizonyos élvezetet találnak az ilyesfajta (ám fiktív és kontrollált) helyzetek megélésében (Nacke, et al., 2014).

Vakmerő (Daredevil): Az izgalom kergetése, a kockázat felvállalása és a pengeélen táncolás jellemzi őket. A gyorsan változó környezetet és nagyfokú koncentrációt igénylő helyzeteket élvezik (nagy sebességgel való közlekedés, folyamatosan változó platformok közötti mozgás stb.). (Nacke, et al., 2014)

Lángész (Mastermind): A bonyolult feladványok, a stratégia-kidolgozást igénylő akadályleküzdés, valamint a legoptimálisabb döntés megtalálása hajtja őket. A Bartle-féle játékostípusok közül a Felfedező áll hozzá közel. (Nacke, et al., 2014)

Győztes (Conqueror): Győzelemig való küzdési vágy, nehéz ellenfelek leküzdése, a többi játékoson való felülkerekedés jellemzi őket (BrainHexBlog, 2008). Szeretnek ellenkezni és küzdeni, egyfajta harag motiválja őket a kihívással szembeni kitartásra. Nemtől függetlenül a tesztoszteron szerepet játszhat a viselkedésében. (Nacke, et al., 2014)

Társasági (Socialiser): Mások társaságát keresi, szeret megbízható emberek között lenni, segíteni másokat, örömközpontját javarészt a bizalom táplálása/elvesztése vezérli (BrainHexBlog, 2008). Megfeleltethető a Bartle-féle modell Társasági típusának (Nacke, et al., 2014). 
Teljesítő (Achiever): Amit lehet, összegyüjt, feltár, felfedezi a játékteret, minden lehetőséget kipróbál, minden feladatot megold (BrainHexBlog, 2008). Míg a Győztes kihívásorientált, addig a Teljesitő expliciten célorientált, hosszútávú eredmények és teljesítendő feladatlista vezérli. A Bartle-modell Teljesitő kategóriájával feleltethető meg. (Nacke, et al., 2014)

Egy 7500 fős mintán végzett kérdőíves kutatás (BrainHexBlog, 2009) szerint a legtöbb kitöltő elsődleges kategóriája a Lángész (23,9\%), őket követik a Felfedezö $(21,7 \%)$ és Gyöztes (20,8\%) játékosok. A Teljesitő típusú viselkedés a válaszolók 11,9\%-ra volt elsődlegesen jellemző, a Közösségi pedig 9,3\%-ukra. A legkisebb aránnyal a Túlélők (7,5\%) és a Vakmerők $(4,9 \%)$ rendelkeznek. Nemek szerinti bontásban némileg módosul a sorrend. A 7 kategóriából 6 ugyanolyan sorrendben követik egymást, de míg a nők körében a Gyöztes kategória csak a 4. helyet foglalja el 13\%-kal, addig a férfiak körében az első helyen áll 28,5\%-os részesedéssel. Ugyanezen kérdőívezés kapcsán két évvel később - miután a kitöltők száma elérte az 50 ezret - megvizsgálták (BrainHexBlog, 2011) az elsődleges és másodlagos kategóriapárok popularitását. A 42 kategóriapárból a GyőztesLángész (8,6\%), Lángész-Gyöztes (7,5\%) és a Győztes-Társasági $(6,1 \%)$ besorolások fordulnak elő a leggyakrabban, míg legritkábban a Vakmerő-Teljesitö, Teljesitő-Vakmerő és a Teljesitö-Túlélö (0,5-0,4-0,4\%) párosok. A 10 legpopulárisabb kategóriapárból 7 esetben a Gyöztes alkotja az egyik felet, 5 esetben a Lángész, 3 esetben pedig a Felfedezö. (BrainHexBlog, 2011)

\subsection{Gamifikáció alkotórészei}

A legtöbb játék, gamifikált rendszer az alábbi alkotóelemek (11. ábra) felhasználásával épülhet fel (Werbach \& Hunter, 2012) (Hunicke, et al., 2004):

- játékelemek,

- játékmechanizmusok,

- játékdinamika,

- szórakoztatási és játékélmény. 


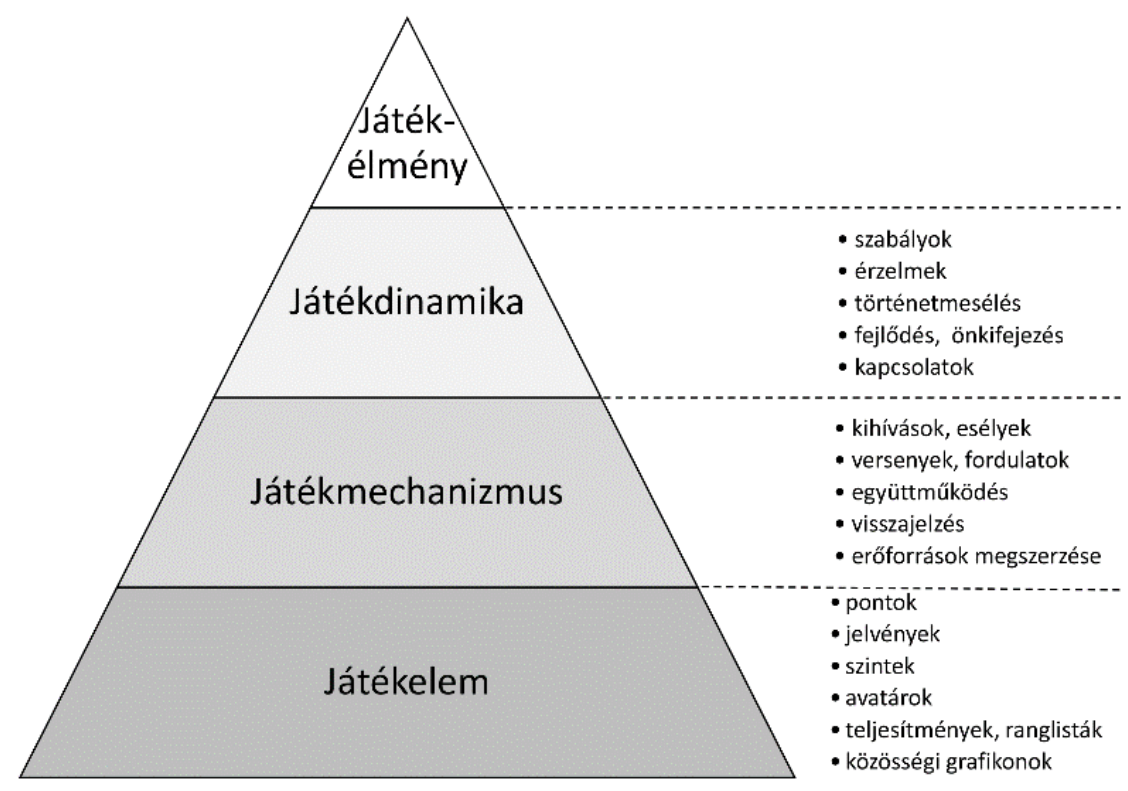

11. ábra: A gamifikáció alkotóelemei ( (Werbach \& Hunter, 2012) alapján)

A hierarchia legalsó szintjén a játékelemek foglalnak helyet. Ezek azok a konkrét elemek, melyekkel a felhasználó már a játék első használatakor szembesül: pontokat és jelvényeket gyüjthet, csapatokat alkothat, kialakíthatja saját karakterét vagy küldetéseket teljesíthet (Werbach \& Hunter, 2012).

A játékelemek szintjére épülnek rá a játékmechanizmusok, melyek leírják, hogy az egyes játékelemek miként kapcsolódnak egymáshoz, illetve hogyan határozzák meg a felhasználó egyes lépéseit és állapotait. A mechanizmusok közé sorolandóak a játék előrehaladását meghatározó iránymutatások, valamint az egy-egy előforduló eseményre várható reakciók is. (Barna \& Fodor, 2018b)

A dinamikák a játékosok viselkedése és egymáshoz való viszonyát írják le, amelyet a játékelemek és mechanizmusok váltanak ki és ösztönöznek. A dinamikákat befolyásolja a felhasználó természete és tapasztalatai. Például egy kockázatkerülö, befelé forduló játékos más viselkedési mintával bír, mint egy kifejezetten kockázatos helyzeteket kereső felhasználó, aki hajlamos extra juttatások reményében könnyebben felvállalni egy hoszszabb játék eredményét is veszélyeztető helyzetet. (Werbach, Hunter, 2012).

Megemlítendő, hogy a gamifikált rendszerek az esetek túlnyomó részében integráltan jelennek meg egy adott online platformon. A játékelemek integrálásától azonban még nem lesz egy rendszerből sikeresen gamifikált alkalmazás. Ennek elősegítése céljából szükséges a játéktervezési szemléletre hagyatkozni, mely a felhasználónak nyújtott 
szórakoztató élményt helyezi a középpontba. Ez az „élmény” több formát is ölthet a problémamegoldástól kezdve a csapatmunkán át a győzelemig rengeteg esemény tudja szórakoztatni a felhasználókat. (Barna \& Fodor, 2018b)

Összességében elmondható, hogy a gamifikáció alkalmazásához számos eszköz áll rendelkezésére, amelyek az üzleti folyamatokat is érdekesebbé, vonzóbbá tehetik. Ugyanakkor nem szabad megfeledkezni arról, hogy egy folyamat attól még nem lesz a felhasználók számára izgalmas, és nem fog elköteleződést kiváltani, ha átgondolatlanul alkalmazunk játékelemeket (Barna \& Fodor, 2018b). Annak érdekében, hogy egy gamifikált alkalmazás elérje a kívánt hatást, ahhoz motiválónak és addiktívnak kell lennie, emellett folyamatos bátorítást szükséges nyújtania, hogy a különböző lehetőségeken keresztül a felhasználó a rövid távú céljait sorra elérje, de mindemellett fenn kell tartania a lehetőséget a hibázásra, bukásra és az újrapróbálkozásra is (O'Donovan, et al., 2013).

A gamifikáció alkotórészeinek elvi ismertetését követően néhány dinamika, mechanizmus és elem bemutatását teszi meg a dolgozat.

\subsubsection{Játékdinamikák}

Szabályrendszer: Az alkalmazás müködési elvét és lehetőségeit határozza meg. A szabályrendszer magába foglalja a felhasználó lehetséges útvonalait, az egyensúly fenntartását és a létrehozandó élményeket. Az útvonalak tervezésénél érdemes kitérni az általános müködés mellett az első használat során alkalmazandó útvonalra. (Werbach, dátum nélk.)

Nehézségi szintek: Egy adott feladat magasabb nehézségi szinten történő elvégzése magasabb honoráriumot von magával, motiválván ezzel a felhasználót, hogy a feladat végrehajtására önszántából több energiát fordítson. A magasabb nehézségi szintért cserébe több pontot kaphat, magasabb presztízsértékkel bíró jelvényt szerezhet, és aktiválhat bizonyos korlátozott hozzáférésü (tudás)elemeket a tudástérképen. (Barna, 2016)

Történet(mesélés): Magas szintű gamifikálási eszköz, ahol már nehezen különböztethető meg, hogy egy játékszerü alkalmazásról vagy kifejezetten egy játékról van-e szó. A tudásátadás és a jutalmazás rendszere egy valós vagy kitalált történet keretei közé korlátozódik, emiatt az egyes feladatok és lehetőségek közti kapcsolat és összefüggés is erősebb, 
ami a játékos számára egy meglehetősen konzisztens megjelenést tanúsít. A történet kiválasztása során figyelembe kell venni az alkalmazás témakörét, a potenciális felhasználók környezetét és szakmai területét. Ha például IT-szakember számára készül egy gamifikált alkalmazás, akkor az IT-területhez kapcsolódó témát szükséges kiválasztani, hogy relevánsnak érezhesse a felhasználó az alkalmazást. (Barna, 2016)

Érzelmek: Az egyén környezettel való interakciójából különféle érzelmek születhetnek, melyek visszajelzésként is szolgálnak az egyén elvárásainak teljesülése kapcsán (Meyer \& Turner, 2006). Az érzelmek tárgya lehet egy kihívás, egy szociális kapcsolat, egy viszszajelzés, látható fejlődés konstatálása, kötődés egy elemhez (pl. avatárhoz) stb. (Sailer, et al., 2013) (Marache-Francisco \& Brangier, 2013)

Fejlődés: Az tekinthető megfelelő játékmenetnek, melynek során a felhasználó érzi, hogy fejlődik, feladatai újabb és újabb kihívást jelentenek, és eközben az érdeklődését nem veszti el (Pacsi \& Szabó, 2017). A Fejlödés dinamikának lényeges építőköve a Visszajelzés mechanizmus és a Fejlödésmutató elem.

Önkifejezés: Azzal, hogy a felhasználó a gamifikált alkalmazás használata során saját énét tudja beletenni, kötődést alakít ki az alkalmazással és (ha adódik rá lehetőség) a többi résztvevővel. Az önkifejezés megvalósulhat saját vélemény megosztásában, az alkalmazás megjelenésének módosításában, avatár/profilkép választásában, célok kiválasztásában stb.

Szociális kapcsolatok: Az embereknek természetüktől fogva szükségük van a szocializációra és az interakcióra (Ryan \& Deci, 2000). Életük számos területén ki vannak téve a társadalmi visszacsatolásnak, és rendszerint el is várják azt (Hassan, et al., 2019). Jelentőségteljes kapcsolatok kialakításával erősíthető a felhasználó szociális elköteleződése, viszont, ha a gamifikációs rendszerben a felhasználót túl hamar kívánjuk szociálisan elkötelezetté tenni, az visszahathat a lelkesedésére, és el is fordulhat magától a rendszertől (Nicholson, 2014).

Ezeken kívül még megjelenhet a felfedezés, gyüjtögetés, versengés, státuszszerzés, kihívás, szerveződés stb. (Blohm \& Leimeister, 2013) dinamikák is. 


\subsubsection{Játékmechanizmusok}

Visszajelzés: Egy azonnali válasz a felhasználó aktivitására (vagy az aktivitás hiányára) segíthet neki jobban megérteni az aktuális kontextust és felülvizsgálni a döntéseiket. (Barna, et al., 2019)

Következmények: A felhasználó döntéseinek különböző kimenetele lehetséges, mely jutalomhoz, büntetéshez vagy épp egy eltérő történetszálhoz vezethet. (Barna, et al., 2019)

Jutalmak: Jutalmak egy feladat elvégzését, a fejlődést vagy egy megtett cselekedetet honorálnak. A jutalmak jellegüket tekintve alapvetően 6 különféle csoportba oszthatóak (nem kizárólagosan): elöre meghatározott akció, véletlenszerü, hirtelen jött, görgetett, szociális kincs és feldarabolt nyeremény (Chou, 2013). Miközben az érdektelen feladatok teljesítéséért felajánlott jutalom növelni tudja a belső motivációt, addig az érdekfeszítő feladatok elvégzéséért pluszban adott jutalom hajlamos csökkenteni és visszafogni a belső késztetést (Cameron, et al., 2001).

Megbocsátás / Újrapróbálkozás: Ahogyan O’Donovan és társai kifejtették (ld. 2.1.3 fejezet), egy gamifikált alkalmazásnak lehetőségek kell teremtenie egy hibás döntés vagy cselekedet „megbocsátására”, és fel kell kínálnia az újrapróbálkozás lehetőségét. (O'Donovan, et al., 2013)

Idő(nyomás): Egy-egy feladatra adott időkeret csökkentésével elérhető, hogy a felhasználó jobban fókuszáljon az adott feladatra (Marczewski, 2017). Döntésének kimenetelét is befolyásolhatja, mert a szükös idő miatt nem biztos, hogy minden eshetőséget alaposan végig tud gondolni, és nem tud minden felmerülő kérdésre külső forrásból választ keresni. (Barna, et al., 2019)

Kuriózum: Gyüjteményként vagy korlátozott készletként is ismert, ám nem feltétlenül köthető csak tárgyhoz. Különlegessége a külső hatás által kontrollált ritkaságában rejlik (Toda, et al., 2019), kivételes képesség vagy szerencse szükséges az eléréséhez.

További mechanizmusok lehetnék még a kihívások, versenyek, esélyek alakítása, fordulatok implementálása, együttmüködés más résztvevőkkel, erőforrások megszerzése és menedzselése stb. 


\subsubsection{Játékelemek}

A gamifikáció által használt játékelemek lehetnek: pontok, rövid és hosszú távú célok, jelvények, felhasználói szintek, státuszindikátorok, fejlődésmutatók, nehézségi szintek, virtuális pénznem, történet, meglepetések (easter eggek), szociális interakciók, tudástérkép, visszajelzés, alkalmazástéma stb. (12. ábra)

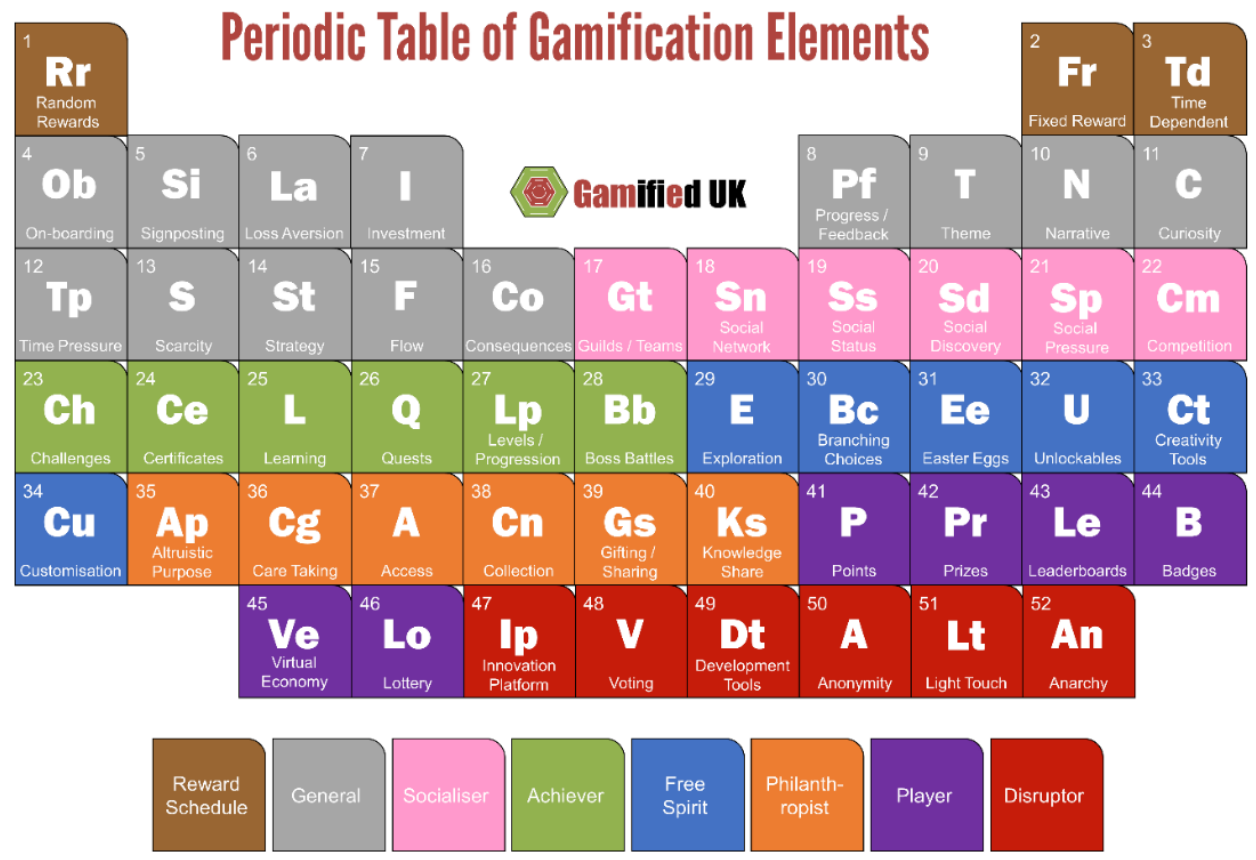

12. ábra: Gamifikációs játékelemek periódusos rendszere (Marczewski, 2017)

Pontok: A legalapvetőbb része a játékoknak. Minden cselekedetért, elért célért, teljesített feladatért stb. a felhasználó különböző mértékü pontértékben részesülhet, mely reprezentálja a szolgáltatásba belefektetett energiáját és idejét. A pontok megmutatják, mennyire tekinthető „sikeresnek”, mennyire tapasztalt az adott játékos az alkalmazás keretei között (Barna, 2016), mindemellett növelik a belső motiváció mértékét (Mekler, et al., 2013). S mivel általában bizonyos teljesítésért cserébe jár mint jutalom, ezért a felhasználó fejlödésének visszacsatolásaként is értelmezhető, mely bátoríthatja a végzett cselekedet folytatására (Mekler, et al., 2013). A pontok egy speciális formája a kulcsfolyamat-indikátorok, azaz a KPI-ok, mely egy adott szempont szerint testesítik meg a felhasználó által nyújtott teljesítményt. Pontalapú jutalmazással növelhető az egyén részvétele, kötődése a szoftveren keresztül végzett tanulás iránt (Li, et al., 2013). Ha azonban csak a részvételéért jár pont és nem a teljesítményéért, akkor nem fog érdemi hatással bírni az elvégzendő cselekedet minőségére (Lister, 2015). 
Célok: Különböző jelentőségű és elvü célok állíthatóak fel a felhasználó számára (pl. egy tananyag-téma feldolgozása, 5 videó megnézése stb.), melyek motiváló hatással bírhatnak rá. Ezeket a célokat előre meghatározhatja maga a rendszer, de érdemes fenntartani annak a lehetőségét is, hogy a felhasználó maga tudja kiválasztani és/vagy beállítani a célok egészét vagy részét, mert ezáltal megadatik számára a választás szabadsága. (Barna, 2016)

Jelvények: Különféle témák feldolgozásával, célok elérésével, különleges feladatok elvégzésével stb. válhat jogosulttá jelvények beszerzésére. Ezek a jelvények tükrözik a felhasználó által elsajátított készségeket és az elért célokat egy egyszerü, tömör, könnyen beazonosítható módon (Barna, 2016). Kutatások igazolják, hogy a jelvények növelik a felhasználó aktivitását és részvételét (Denny, 2013) (Grant \& Betts, 2013). A feladat teljesítésével elégedettséget éreznek (Goehle, 2013), és szeretik a szerzeményeiket elújságolni, ám mások kimondottan közömbösen viseltetnek irántuk (Haaranen, et al., 2014). Diákok esetében megfigyelhető, hogy az alulteljesítő hallgatókra inkább a részvételalapú díjazás és jelvényosztás hat motiválóan, míg a magasan teljesítők esetén a teljesítményalapú díjazás ad nekik motivációt (Abramovich, et al., 2013).

Felhasználói szintek: Az összegyüjtött pontszám, elért célok és a beszerzett jelvények alapján a felhasználó egyre magasabb felhasználói szintet érhet el, mely tükrözi a rendszerrel kapcsolatos jártasságát (Barna, 2016).

Folyamatjelzők / Fejlődésmutatók: ezek a mutatók reprezentálják az aktuális állapotát a felhasználó célelérési folyamatában (pl. mennyi pontra van szüksége a következő szint eléréséig), viselkedésére vonatkozó adatot közölhet (pl. az elmúlt 1 hónapban hányszor használta az alkalmazást), a megszerezni kívánt készség teljesítményértékét mutatja (pl. a készséghez teljesítendő tananyagtémák közül hányat teljesített már), és vizualizálja a teljes ,játékmenet” állapotát. (Barna, 2016)

Tudástérkép: Egy áttekintő térkép, amely tartalmazza az összes már elérhető és a még nem aktivált témaköröket, valamint a köztük lévő függőségeket. Minden elemet egy-egy pont képvisel, és ezek akár további alelemeket is tartalmazhatnak, amikhez szintén tartozhat további alelem. A térképet látván a felhasználó át tudja gondolni, hogy a folyamat során milyen útvonalat szeretne követni, egy-egy elem aktiválásához milyen 
teljesítményeket kell nyújtani, milyen készségeket kell elsajátítania, megadva ezzel a felhasználónak a döntés szabadságát. (Barna, 2016)

Aktivitáspontok: Ezek a fajta pontszámok a felhasználó aktivitását tükrözik, például az alkalmazáshasználat gyakoriságát, megtekintett tartalmak számát, összegyüjtött jelvények számát stb. (Barna, 2016)

Virtuális valuta: A különböző feladatok elvégzéséért, célok eléréséért, bizonyos lépésekért a felhasználó nemcsak (tapasztalati) pontjutalomban részesíthető, hanem virtuális pénzt is gyüjthet. Ebböl a pénztárcából alkalmazáson belüli vásárlásokat, kiegészítőket, extrákat, funkciókat stb. vásárolhat, vagy akár olyanokat, melyeknek a valós életre gyakorolt hatásuk is van, kilépvén a gamifikált folyamat alkotta rendszer keretei közül (pl.: alkalmazásspecifikus póló vásárlása). (Barna, 2016)

\subsection{4. Üzleti hasznosításuk}

A gamifikációs elemek, mechanikák és dinamikák használata során az emberekre kifejtett pszichológia hatásokat üzleti értelemben definiált célokra is átkonvertálhatóak. Noha öszszességében a gamifikáció a felhasználói motiváció és elköteleződés növelésével hozzájárul egy adott termék vagy szolgáltatás megnövelt időtartamú használatához, az egyes alkotóelemek közvetlen hatásai is beazonosíthatóak. Eme közvetlen hatások ismerete hozzásegítheti a folyamatok újratervezésével foglalkozó szakembereket az általuk kívánt üzleti, gazdasági, marketing, egyéb cél érdekében választandó gamifikációs alkotóelemek kiválasztására, a hangsúlyok elosztására.

Juno Hamari és Vili Lehdonvirta munkájuk során (Hamari \& Lehdonvirta, 2010) arról értekeztek, a játéktervezés során használt mechanikák miként járulnak hozzá a marketing célok elősegítésében. Az általuk összegyüjtött elemek többnyire a szegmentációhoz, differenciáláshoz és a(z ismételt) vásárlás ösztönzéséhez járultak hozzá. A szegmentálás a marketing egyik alapvető és központi fogalma. Célja a populációk azonosítása és stratégiai szempontból releváns homogén szegmensekre bontása a szegmentációs változók és az ügyfelek igényei alapján. Ez lehetővé teszi a vállalatok számára, hogy marketing erőforrásaikat az adott szegmens meghatározó tulajdonságai szerint hasznosíthassák (Keller \& Kotler, 2008). A játéktervezés során a szegmensek elkülönítésével meghatározható, hogy az egyes csoportok számára milyen virtuális javakat kínáljon fel az üzleti 
szolgáltatás (Hamari \& Lehdonvirta, 2010). A differenciálás szintén a marketing alapfogalmaihoz tartozik. A termékek megkülönböztetésének célja a nagyobb kívánatosság elérése, és a rivális szereplők termékeitől való megkülönböztetéssel az értékesítés előmozdítása (Sharp \& Dawes, 2001). A differenciálások a termékek jellemzőinek egy adott sokaságán alapulhatnak, ám alapvetően két általános alcsoportra oszthatóak, vertikális és horizontális megkülönböztetésre. Vertikális differenciálás esetén azokat a jellemzőket vesszük alapul, melyek összehasonlíthatóak a piaci riválisok termékeinek attribútumaival (ár, kényelem, exkluzivitás, használhatóság stb.), és minőségi különbséget lehet tenni. Horizontális esetén más tulajdonságkészlet nyújtásával (eltérő szín, stílus, íz stb.) történik a megkülönböztetés, nem lehet egyértelműen minőségi sorrendet állítani (pl. sztracsatella és sárgadinnye ízesítésủ fagylaltok). Az alábbi táblázat néhány gamifikációs alkotóelem esetében meghatározza, hogy marketing szempontból milyen cél segítését teszik azok lehetővé. (3. táblázat)

\begin{tabular}{|c|c|}
\hline Alkotóelem & Üzlethasznosítási cél (marketing) \\
\hline Rétegelt tartalom & $\begin{array}{l}\text { Szegmentáció létrehozása, differenciálás engedélyezése, is- } \\
\text { mételt vásárlás ösztönzése }\end{array}$ \\
\hline $\begin{array}{l}\text { Státuszszinthez kötött tar- } \\
\text { talmak }\end{array}$ & Szegmentáció erősítése, ismételt vásárlás ösztönzése \\
\hline $\begin{array}{l}\text { Növekvő kihívást jelentő } \\
\text { tartalom }\end{array}$ & Szegmentáció erösítése, ismételt vásárlás ösztönzése \\
\hline $\begin{array}{l}\text { Multidimenzionális játék- } \\
\text { menet }\end{array}$ & $\begin{array}{l}\text { Szegmentáció létrehozása, differenciálás engedélyezése, a } \\
\text { (virtuális) javak többszintü/többszöri beárazása }\end{array}$ \\
\hline Javak értékcsökkentése & Ismételt vásárlás ösztönzése \\
\hline $\begin{array}{l}\text { Kényelmetlen játékmenet } \\
\text { elemek }\end{array}$ & Igény támasztása további virtuális javak, szolgáltatások iránt \\
\hline Virtuális valuta & (Ismételt) vásárlás ösztönzése \\
\hline $\begin{array}{l}\text { Leltár-/Készlet-mecha- } \\
\text { nika }\end{array}$ & Ismételt vásárlás ösztönzése \\
\hline Különleges alkalmak & $\begin{array}{l}\text { Vásárlási hajlandóságot erősítő kulturális minták kihaszná- } \\
\text { lása, a (virtuális) javak többszintü/többszöri beárazása }\end{array}$ \\
\hline Mesterséges hiány & Ismételt vásárlás ösztönzése (exkluzivitás révén) \\
\hline $\begin{array}{l}\text { Meglévő tartalmak vál- } \\
\text { toztatása }\end{array}$ & (Virtuális) javak többszintü/többszöri beárazása \\
\hline
\end{tabular}

3. táblázat: Alkotóelemekhez társított üzlethasznosítási célok (Hamari \& Lehdonvirta, 2010) 


\subsubsection{Sötét minták}

A gamifikáció alkotórészeit arra használják, hogy a felhasználók bizonyos módon befolyásolják, rávegyék az alkalmazás használatára, egy akadály leküzdésére, egy adott cselekedet elvégzésére. Ha ez a befolyásolási szándék üzlethasznosítással jár, előfordulhatnak olyan megoldások, melyek a kívánt cselekedet (pl. vásárlás) végrehajtatása érdekében a gamifikációs folyamatba sötét mintákat (vagy sötét mechanizmusokat) implementálnak. A sötét minták olyan felhasználóifelület-tervezési döntések, melyek a gamifikációs alkalmazás (pl. webshop) javát szolgálják oly módon, hogy a résztvevőt váratlan vagy potenciálisan káros döntések meghozatalára kényszerítik megtévesztés vagy félrevezetés útján (Mathur, et al., 2019). Legjobb esetben a sötét minták csak bosszantják a felhasználókat, ám könnyen okozhatnak pénzügyi veszteséget a felhasználónak, kicsalhatnak tőle nagy mennyiségü személyes információt, vagy kényszeres és addiktív viselkedést válthatnak ki mind felnőttekből, mind gyerekekből (Mathur, et al., 2019).

A sötét minták jellemzően 5 típusba sorolhatóak: zaklató, akadályt állító, bekúszó, interfészt módosító és kényszerítő (Gray, et al., 2018). Az alábbiakban néhány sötét minta kerül ismertetésre:

- Csali és csere: Egy kívánt cselekedet helyett egy másik, nem kívánatos cselekedet történik meg (Gray, et al., 2018);

- Figyelem elterelése (Gray, et al., 2018);

- Rejtett hirdetés: Relevánsnak tünő tartalomként vagy navigációs elemként feltüntetett hirdetés (Brignull, dátum nélk.);

- Rovarcsapda: Egy adott szituációba való bekerülés teljes mértékben akadálymentes, ám az onnan való kikerülés bonyodalmas folyamat (pl. előfizetés vagy feliratkozás lemondása) (Gray, et al., 2018);

- Trükkös kérdések;

- Szégyenteljes döntés: Szégyenérzet keltése a felhasználóban passzív-agresszív módon (pl. Az elutasító gombon „Nincs szükségem a kedvezményre.” felirat szerepel), ha a szolgáltatás számára egy nem kedvező döntést szeretne meghozni a felhasználó (Brignull, dátum nélk.). 
- „Darálás”: Ismétlődő feladatok végrehajtatása. Jellemzően játékokban használatos, hogy a felhasználó szükségtelenül több időt töltsön el vele. Játékon kívüli alkalmazása lehet egy olyan cselekvéstípus kényszerített újravégzése, mely plusz költség megfizetésével automatizálttá tehet a felhasználó (pl. hírlevélküldés) (Pusztai, 2018);

- Időpont-egyeztetés: Megköveteli a felhasználótól, hogy egy adott időpontban térjen vissza a szolgáltatáshoz (Pusztai, 2018);

- Korlátozott időkeret / Visszaszámlálás (Mathur, et al., 2019);

- Kényszerített folytatás: Pl. az ingyenes próbaidőszakot követően a szolgáltatás díja automatikusan levonásra kerül a bankszámláról (Gray, et al., 2018);

- Korlátozott hozzáférés (Pusztai, 2018);

- Rejtett költségek (Gray, et al., 2018);

- Ár-összehasonlítás akadályozása (Gray, et al., 2018);

- Kosárba kúszás: A vásárlási folyamat során félig rejtett (pl. eleve bejelölt választási lehetőség) módon bekerül egy újabb, nem szándékosan megvenni kívánt termék a kosárba (Gray, et al., 2018);

- Készlet-értesítés: A megvásárolni kívánt termék adatlapján a készlet alacsony mértékéről és/vagy gyors fogyásáról tájékoztat (Mathur, et al., 2019)

- Piramis-rendszer (Pusztai, 2018);

- Ismerősök „,spammelése”: A szolgáltatás a felhasználó nevében üzeneteket küld a felhasználó ismerőseinek (Gray, et al., 2018);

- Magánélet „,zuckerelése”: A felhasználó a szándékozottnál több információt oszt meg a magánéletéről, (A kifejezés a Facebook alapítójáról, Mark Zuckerbergről kapta) (Gray, et al., 2018);

- Aktivitási értesítések: Az oldalon hirtelen megjelenik egy értesítés, melyben egy vélt vagy valós felhasználó legutóbbi vásárlásáról tájékoztat, vagy megmutatja az adott terméket aktuálisan megtekintő felhasználók számát stb. (Mathur, et al., 2019);

A sötét minták alkalmazása jelentős jogi aggályokat vet fel. 2014-től kezdve az Európai Unió területén belül zajló e-kereskedelmi szolgáltatások számára tiltott módszernek 
számít a Kosárba kúszás, a Rejtett költségek, a Kényszerített folytatás és a Csali és csere használata (Brignull \& Burns, 2014). Az USA-ban 2019-ben tárták a kongresszus elé a DETOUR (Deceptive Experiences to Online Users Reduction) indítványt, mellyel korlátoznák - a 100 milliónál több felhasználóval rendelkező szolgáltatások esetében - a felhasználók befolyásolására irányuló interfész- és folyamattervezést (Dornisch, 2020). 


\section{KUTATÁSI KÉRDÉSEK}

Kutatásaim során az elsődleges általános célom olyan esetek és elektronikus megoldások vizsgálata volt, mely gamifikációs elemek segítségével az adott felhasználóban erősíteni tudja a motivációt, és ezáltal hozzá tudja segíteni az alkalmazás fő céljához, mely lehet a munkavállalói elköteleződés növelése vagy a tanulási hajlandóság erősítése. Munkáim két irányvonalat vettek fel. Az egyikben a vállalati közegben alkalmazott és alkalmazható lehetőségek vizsgálatára helyeztem a hangsúlyt, míg a másikban az oktatásban használható alkalmazások és e-learning rendszerek lehetőségeit vettem célba.

\subsection{Vállalati közeghez kapcsolódó kutatás}

Az első témakörben a vállalati közegben, céges környezetben alkalmazott és alkalmazható lehetőségek vizsgálatára helyeztem a hangsúlyt. A vizsgálatok javarészt magyar vállalatokat ölelnek fel, ám jelentős mértékben szerepelnek külföldi szervezetek is a vizsgált populációban. A munkavállalók jellegét tekintve az irodai munkakört betöltők képezték a vizsgálatok alanyait. Mivel egy szervezet számára lényeges szempont, hogy meg tudják-e tartani a munkaerőt középtávon ( 3-4 évig), ezért a fő cél a munkavállalók munkahelyükkel való megelégedettségének vizsgálata volt, s emellett a munkavállalók összetettségének elemzését tűztem ki még célul egy célszoftver segítségével, név szerint a Battlejungle ${ }^{6}$ szolgáltatás működésén keresztül. Az összetettségelemzés segítheti a szervezetet a cégben meglévő rejtett képességek feltárásában. Az első kérdéscsoport az alábbiakból tevődik össze:

- Kv1: Hozzá tud-e járulni a vizsgált gamifikált online szolgáltatás a munkavállalói elköteleződéshez?

○ $\mathrm{K}_{\mathrm{V}} 1_{\mathrm{A}}$ : Hozzá tud-e járulni a vizsgált gamifikált online szolgáltatás a munkahelyi légkör javításához?

\footnotetext{
${ }^{6}$ https://battlejungle.com/
} 
○ KV1 $1_{\mathrm{B}}$ : Hatással bír-e a vizsgált gamifikált online szolgáltatás a munkahelyi kapcsolati hálók minőségének és mennyiségének növekedésére?

- $\mathrm{K}_{\mathrm{V}} 2$ : Csoportosíthatóak-e a vizsgált gamifikált online szolgáltatás felhasználói a szolgáltatásban tanúsított viselkedésük alapján?

\subsection{Oktatáshoz kapcsolódó kutatás}

A második irányvonal az információtechnológia területét érintő egyetemi oktatásban megjelenő gamifikáció lehetőségét hivatott vizsgálni, különösen a hallgatók motivációjára gyakorolt hatását. Mivel az edukációs „,projektek” (úgymint kurzusok) rendszerint rövidtávúak, csak 1 félévet tesznek ki (avagy 12 tanóra/alkalom), ezért ezen kutatások fö célja a hallgatói motiváció, valamint a folyamatos és eredményes tanulási készség fejlesztése az adott kurzus ideje alatt. Ezek alapján a következő kutatási kérdések köré épülnek a vizsgálatok:

- $\mathrm{K}_{\mathrm{O}} 1$ : Lehetséges-e meglévő e-learning rendszerbe épített további gamifikációs elem segítségével a motiváltságot növelni?

- $\mathrm{K}_{\mathrm{O}} 2$ : Kimutatható-e különbség a gamifikációs elemeket használó és nem használó tanulók elégedettsége között?

Ezen kérdések vizsgálatához és megválaszolásához követett módszertanok a következő fejezetben kerülnek részletezésre. 


\section{KUTATÁSOK MÓDSZERTANA}

Mindkét irány esetében elektronikusan történt a kutatás, a mérés, a kísérlet és az eredmények összegzése, kvantitatív módszerek segítségével.

\subsection{Vállalati közeghez kapcsolódó kutatások módszertana}

A kutatási irányvonal lépéseit tekintve (13. ábra) elsőként a felhasználható adatok és jellemzők összegyüjtése történt meg, majd a vizsgált szolgáltatás felhasználóinak azonosítása és leíró statisztikai jellemzésük következett. A felhasználók által tanúsított viselkedésen alapuló vizsgálatok 3 altémát érintenek: játékosok kategorizálása, munkahelyi légkör változásának vizsgálata és a kapcsolati háló alakulásának vizsgálata. Miután megtörtént a játékosok historikus adatain alapuló elemzés, a kísérleti jelleggel alkalmazott regisztrációkori 2x5 kérdéses kérdőívre adott válaszaik tényleges aktivitásaikkal összevetésre kerültek, melyekből valószínüsíthető viselkedési mintákat von le az értekezés.

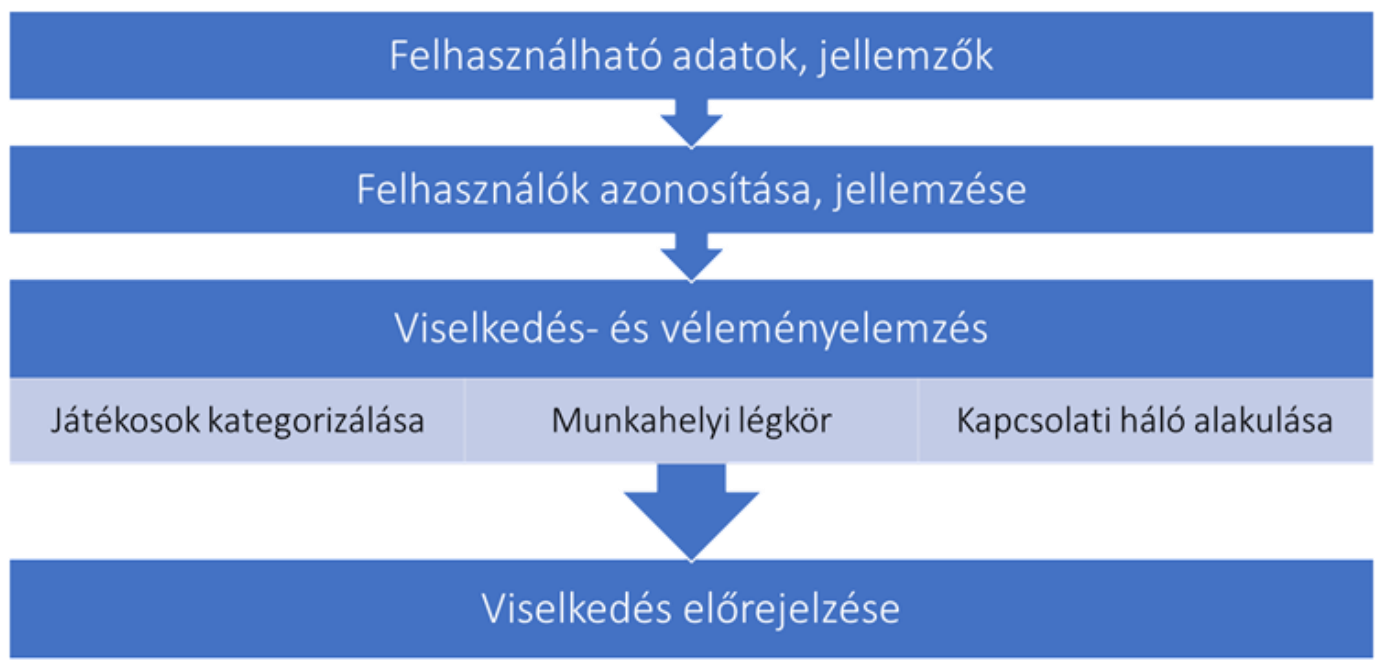

13. ábra: Vállalati közeget érintő kutatás lépcsőfokai (Saját ábra)

A kutatások alapvetően 3 típusú adattal operáltak: leíró jellegű, aktivitás jellegű és véleményalapú (14. ábra). A munkahelyi elégedettség mérését célzó kutatási adatok forrását a „Battlejungle” nevezetü online szolgáltatás által nyújtott, valamint a „Google Analytics” által szolgáltatott adatok adták. Az egyéni felhasználókról gyűjtött, viselkedésüket nem tartalmazó leíró adatokért - úgymint az életkor-besorolás, nem, lokalizáció, érdeklődési 
terület - a Google Analytics felelt. Mivel a Google Analytics maximum 3-hónapos időintervallumról enged aggregált adatokat szolgáltatni, így az 5. fejezetben részletezett kutatás során a leíró statisztika 3-hónapos időszakok aggregált adatait takarja.

A felhasználók viselkedését, aktivitásait és véleményeit a Battlejungle szolgáltatás által generált adatok alapján kerültek elemzésre. Az aktivitási hajlandóság a szolgáltatás honlapjának látogatásából, a belső felületre történő belépésből következtethetőek.

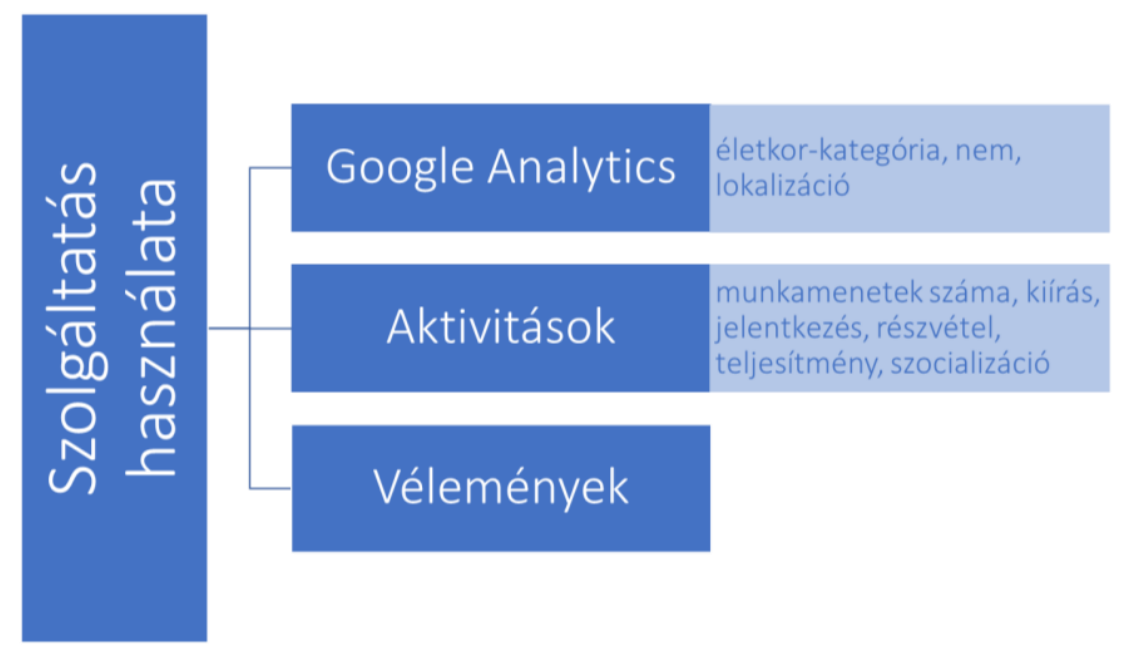

14. ábra: Vállalati közeget érintő kutatás során felhasznált adatok és jellemzők (Saját ábra)

Viselkedésüket a szolgáltaltatás funkcióinak használatához kötjük, úgymint aktivitások kiírása (mely magába foglalja mind az egyszerűen jelenlétet igénylő eseményeket, valamint a tevékenységet elváró kihívásokat, versenyeket, bajnokságokat is), azokra való jelentkezés, folyamatban lévő események által elvárt tevékenységek elvégzése (jelentkezés, eredménybejelentés) és a szociális funkciók használata (posztolás, reakció posztokra, kommentálás, profilmegtekintés, ranglista nyomon követése stb.). A felhasználók véleményeinek vizsgálata a honlap különböző pontjain elhelyezett, skálaalapú visszajelzési kérdésekre adott értékelések összegzésével történt meg.

\subsubsection{A vizsgált gamifikált csapatépítő alkalmazás (Battlejungle)}

A gamifikáció lehetőségének elemzéséhez elsősorban a „Battlejungle” online szolgáltatás (Battlejungle, 2019) nyújtotta folyamatokat és adatokat dolgozza fel a dolgozat, amely szolgáltatásnak célkitüzése a munkatársak közti kapcsolatok számának és minőségének növelése, a munkahelyi légkör fejlesztése, valamint a munkavállalói motiváció erősítése. 
A vizsgált szolgáltatás a munkavállalók közötti (sportjellegü) események szervezéséhez és ösztönzéséhez nyújt támogatást. Alapesetben események meghirdetéséhez nyújt támogatást, de lehetőséget ad különböző sportversenyek lebonyolításához és menedzseléséhez is. A sportesemények két nagy csoportra oszthatóak: az egymás elleni, összecsapásokon (egy-egy ellen, csapat-csapat ellen) alapú bajnokságokra (versus), úgymint az asztalitenisz vagy a futball, valamint az egyéni vagy csapat által elért teljesítmény összehasonlításán alapuló eseményekre (race), mint például a futás. A rendszeres testmozgás ösztönzésére számos más alkalmazás (ld. 2.1.4.1. fejezet) is használja a gamifikáció adta lehetőségeket, ám ezek leginkább csak az „egyéni” sporttevékenységeket (futás, kerékpározás, túrázás stb.) támogatják, de nem teszik lehetővé csapatjátékok szervezését, lebonyolítását és dokumentálását.

Az alkalmazás 2019 októberétől (üzleti modell váltása révén) korlátozottabb ingyenes használatot enged, ám továbbra is kipróbálható fizetés nélkül. Az előre definiált fizetési csomagok kielégítik a legtöbb, $\mathrm{KKV}^{7}$ kategóriába tartozó cég igényét, a nagyvállatok számára pedig személyre szabási lehetőségeket is kínálnak. Az előfizetési csomagok magukban foglalják a speciális lebonyolítást nem igénylő események kiírását és menedzselését (regisztráció, értesítés, összegzés, esemény landing oldala, letölthető poszter stb.), az elöre elkészített, különleges lebonyolítást és felületi adminisztrálást igénylö aktivitásokat pedig a szolgáltatás online boltjából felárért lehet használni. (Battlejungle, 2019)

A Battlejungle szolgáltatás létrehozásában kulcsfontosságú szerepem volt, jelenleg is tulajdonosként és fejlesztési vezetőként vagyok jelen, ám ez a munka nem képezi részét a kutatásomnak, nem tartalmazza a dolgozat sem. A tudományos munkám során a szolgáltatás outputját és adathalmazát használtam fel, ám kutatást előkészítő, munkafolyamatokat utólag befolyásoló fejlesztésre nem adódott lehetőség.

\footnotetext{
${ }^{7} \mathrm{KKV}$ : Kis- és középvállalkozások
} 


\subsubsection{A vizsgált gamifikált csapatépítő alkalmazás gamifikációs elemei}

A szolgáltatás számos játékelemet integrált annak érdekében, hogy megfogja a felhasználók figyelmét, szórakoztató élményt kínáljon, és motivációt nyújtson a felületen menedzselt közös és/vagy egyéni tevékenységekben való részvételre.

\section{Pontok}

A szolgáltatás gamifikált rendszere a $\mathrm{PBL}^{8}$-hármasra épül. A felhasználók összemérhetőségére egy pontrendszer szolgál, melyet a rendszer „karmának” nevez. (A továbbiakban a dolgozat a vizsgált gamifikált szolgáltatás tekintetében ugyanazt az elemet érti a ,pont” és a „karma” kifejezés alatt.) A pontrendszer rögzít teljesítményalapú, valamint aktivitásalapú pontokat is.

Teljesítményalapú pontok a különféle eseményeken és megmérettetéseken, versenyeken való részvétellel szerezhetőek. A hagyományos („,közösségi”, „szociális”) események esetén (pl. véradás, előadás, karácsonyi parti), mely során csak jelenlétet figyelnek és nincs megkülönböztető bánásmód, a résztvevők ugyanannyi pontot kapnak.

Annak érdekében, hogy a játékosok motiváltak legyenek a minél több embert megmozgató versenyek megszervezésére és az azokban való részvételre, a felkínált pontérték függ a szervezet (a rendszerben egy szervezeti fiók alatt csoportosuló felhasználók összessége) és a bajnokság (megmérettetési eseménysorozat) létszámarányától, valamint figyelembe veszi az egy résztvevő által játszható meccsek átlagos számát (mely függ a bajnokság lebonyolítási módjától [pl. körmérkőzés, egyenes kiesés vagy vegyített]). A következő képlet szemlélteti egy új résztvevő csatlakozása esetén a bajnokság befejezésekor kiosztandó karma növekményének kiszámítási módját. (Barna \& Fodor, 2018b)

\footnotetext{
${ }^{8}$ Points, Badges, Leaderboards; azaz Pontok, Jelvények, Ranglisták
} 


\section{karmaPerParticipant}

$$
\begin{aligned}
& =\text { initialKarma } *\left(0.5+\frac{\text { magnitudeOfTournament }}{2 * \max (1, \text { magnitudeOfOrganisation })}\right) \\
& * I F(\text { isVersusTournament } ; \min (1,0.5 \\
& \left.\left.+\frac{\text { numberOfMatchesOfLoser }}{2 * \max (1, \text { \$numberOfMatchesOfWinner })}\right) ; 1\right)
\end{aligned}
$$

\footnotetext{
karmaPerParticipant: egy bajnokság befejezésekor kiosztandó pontérték növekménye egy új résztvevő csatlakozásakor; initialKarma: kiinduló pontérték;

magnitudeOfTournament: a bajnokság résztvevőszámának 2-es alapú logaritmusának egész értéke; magnitudeOfOrganisation: a szervezet taglétszámának 2-es alapú logaritmusának egész értéke; isVersusTournament: igaz-e, hogy a vizsgált bajnokság Versus típusú;

numberOfMatchesOfLoser: az utolsó helyen végző játékos által játszható meccsek száma; numberOfMatchesOfWinner: az első helyen végző játékos által játszható meccsek száma;
}

Ily módon minél több felhasználó vesz részt egy bajnokságban, annál magasabb pontszámokat kaphatnak egy-egy mérkőzésük vagy eredmény-bejelentésük során, valamint annál magasabb az összesített pontérték, mely a verseny lezárulta után a helyezések között oszlik szét (,,karma pool”) (4. táblázat).

\begin{tabular}{|c|c|c|c|c|c|c|c|c|c|}
\hline \begin{tabular}{c} 
Bajnokság \\
(fó) \\
\hdashline-----
\end{tabular} & $\mathbf{2}$ & $\mathbf{4}$ & $\mathbf{8}$ & $\mathbf{1 6}$ & $\mathbf{3 2}$ & $\mathbf{6 4}$ & $\mathbf{1 2 8}$ & $\mathbf{2 5 6}$ & $\mathbf{5 1 2}$ \\
$\begin{array}{c}\text { Szervezet } \\
\text { (fó) }\end{array}$ & 150 & & & & & & & & \\
\hline $\mathbf{2}$ & 113 & 150 & & & & & & & \\
\hline $\mathbf{4}$ & 100 & 125 & 150 & & & & & & \\
\hline $\mathbf{8}$ & 94 & 113 & 131 & 150 & & & & & \\
\hline $\mathbf{1 6}$ & 90 & 105 & 120 & 135 & 150 & & & & \\
\hline $\mathbf{3 2}$ & 88 & 100 & 113 & 125 & 138 & 150 & & & \\
\hline $\mathbf{6 4}$ & 86 & 96 & 107 & 118 & 129 & 139 & 150 & & \\
\hline $\mathbf{1 2 8}$ & 84 & 94 & 103 & 113 & 122 & 131 & 141 & 150 & \\
\hline $\mathbf{2 5 6}$ & 83 & 92 & 100 & 108 & 117 & 125 & 133 & 142 & 150 \\
\hline $\mathbf{5 1 2}$ & & & & & & \\
\hline
\end{tabular}

4. táblázat: „Vegyített” lebonyolítási elvü bajnokság „karma pool”-jának résztvevőnkénti pontnövekménye egészértékre kerekítve (Barna \& Fodor, 2018b)

Aktivitásalapú pontok olyan cselekvések elvégzése után jár, amelyek a szervezettel vagy a rendszerrel történő foglalkozásra irányulnak, úgymint az oldal meglátogatása, eredmény megosztása, vagy visszajelzés küldése. (Barna \& Fodor, 2018b) 


\section{Jelvények}

Az elsősorban a Teljesitö és Felfedezö típusú játékosok számára kedveznek a rendszer által kínált különféle jelvények (Hiba! A hivatkozási forrás nem található.). A jelvények irányulhatnak versenybéli teljesítmény elérésére, időponthoz köthető eseményekre, valamint szocializációs tevékenységek végzésére is. (Battlejungle, 2019)

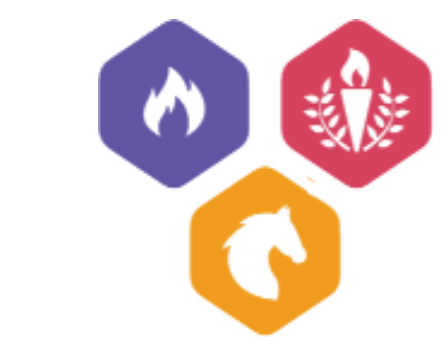

15. ábra: A Battlejungle rendszerében gyüjthető jelvények közül 3 darab

(Battlejungle, 2019)

\section{Szintek}

A vizsgált alkalmazásban a játékosok különböző felhasználói szinteket érhetnek el, melyek az elért összesített pontszámaikon alapul. A felhasználói szintek az állatvilág témájára épül. 15 szint különül el, a Heroic Hamster-től egészen a Grand Gorilla-ig (ez utóbbiból maximum egy lehet szervezetenként) (Battlejungle Support, 2016). Az alkalmazásra adott személyes, kötetlen hangvételü visszajelzések alapján a felhasználói szint az egyik legkedveltebb gamifikált elem, felülmúlva ezzel a jelvényeket és a karmát.

Annak érdekében, hogy a felhasználó már az első belépésekor részesüljön önmaga fejlődésében, ezért, ha az alapinformációkat bekérő és magyarázatokat felvonultató First Use Tour során profilképet is állít be, rögtön elnyeri az „It's-a me!” jelvényt.

\section{Előrehaladás, ranglista}

Kompetitív játékosok számára fontos játékmechanizmus, folyamatosan ellenőrizheti a többiekhez mért, ponton alapuló helyzetét. Ez egy állandó és azonnali visszajelzés a cselekvések jutalmazására. A vizsgált szolgáltatásban minden egyes verseny kapcsán megtalálható az aktuális helyezése a játékosnak, valamint az összesített pontértéke alapján a szervezeti rangsorban megtalálható helyét is megtekintheti. Annak érdekében, hogy a nem a legjobb 5-10\%-ba tartozó játékosokat ne demotiválja az alacsonyabb helyezés, a föoldalon a ranglistán csak a közvetlen környezete látható, a játék előtt és után álló 2-2 fővel. 


\section{Közösségi interakciók}

A vizsgált alkalmazás közösségépítő vonala három fő részből tevődik össze. Az első a kommunikáció, melyet a közösségi médiában is használt posztolás, kommentálás, hangulatkinyilvánításban valósul meg (Barna \& Fodor, 2018b). A második összetevője a naptár nézet, mely egy helyen tartalmazza az összes meghirdetett, folyamatban lévő vagy már lezajlott események, fordulók, mérkőzések időpontjait, függetlenül attól, hogy a játékos feljelentkezett-e az adott eseményre vagy sem. A harmadik pillér pedig a szolgáltatáson kívülre mutat, a felhasználó meg tud osztani bizonyos okleveleket és jelvényeket több közösségi médiumon keresztül. (Barna \& Fodor, 2018b)

\section{A gamifikált szolgáltatás hatásának mérőeszközei}

Az alkalmazás a felhasználók munkahelyi életvitelére gyakorolt hatását kétféle módon vizsgálja a dolgozat. Először a rendszer által gyüjtött adatok feldolgozása történik meg, többek között a játékos pontszáma, szintje, aktivitása, bajnokságokban való részvétele és ténylegesen lejátszott meccseinek száma által. Szervezeti szinten a tagok között létrehozott kapcsolatok száma, sikeresen lezajlott vagy aktív bajnokságok aránya, közösségi funkciók használata (post, komment, like megosztás), aktív játékosok, preferált sportágak stb. segítenek az elemzésben. (Barna \& Fodor, 2018b)

A mérések másik pillérét a felhasználóktól közvetlenül érkező, a szolgáltatás felületén feltett kérdésekre adott válaszok alkotják. Minden kérdés esetében 2-5 válasz kínálkozik fel, melyek közül egyet választhat a felhasználó. A visszajelzés 1-1 kérdés megválaszolásával történik, mely egy elöre meghatározott kérdésbankból kerül kiválasztásra a felhasználó számára attól függően, hogy milyen tevékenységet végzett éppen, a rendszer mely oldalán jár, és milyen hasonló jellegű kérdést válaszolt már meg. (Barna \& Fodor, 2018b)

A kapott eredmények pontosabb megértéséhez a Google Analytics által nyújtott adatok is elemzésre kerülnek, ezek segítségével történik a felhasználók lokalizációs, nem, kor és érdeklődés szerinti összetételének elemzése. (Barna \& Fodor, 2018b) 


\subsection{Oktatáshoz kapcsolódó kutatások módszertana}

Az oktatás jellegü kutatásaim (16. ábra) nagyobb része a Moodle e-learning rendszeren alapul. Először magáról a rendszerről és annak képességeiről, funkcióiról zajlott adatgyüjtés.

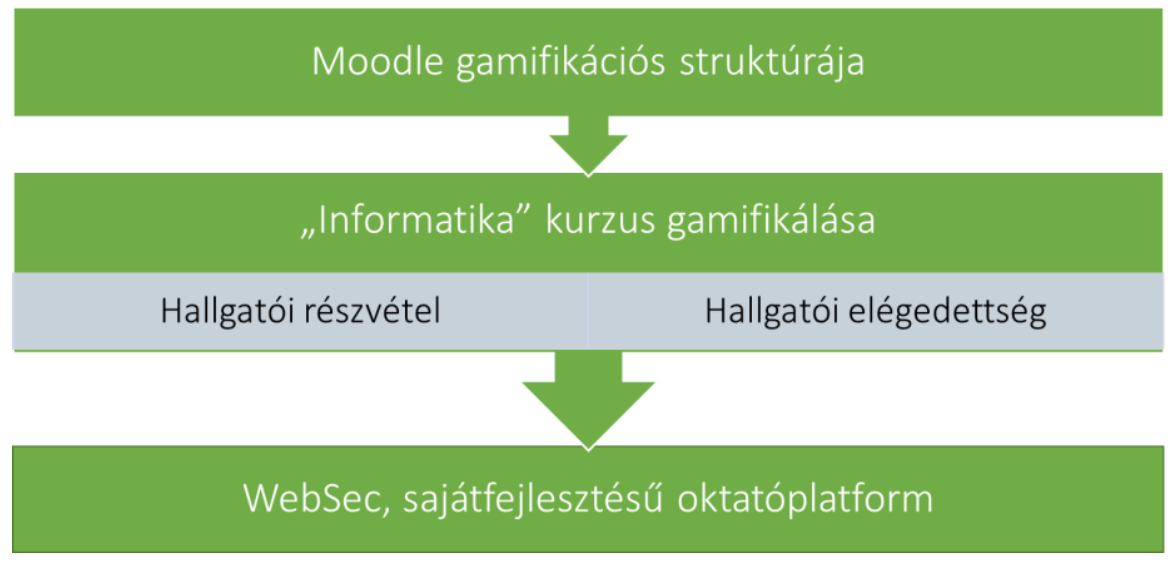

16. ábra: Oktatási közeghez kapcsolódó kutatás lépcsőfokai (Saját ábra)

Az átalakítandó kurzus során a gamifikációs lehetőségeket is feltérképeztük, majd ezt követően bizonyos elemek közvetlenül kerültek alkalmazásra (különböző útvonal, eléréskorlátozás, pontszámítás), míg más elemeket exportálás, saját kezüleg írt algoritmus lefuttatása, s annak outputjának visszaimportálásának segítségével alkalmaztunk. A hallgatócsoportok jellemzése során azok létszámaitól és tagozati besorolásuktól (nappali vagy levelezős) eltekintve más leíró jellegű statisztikai elemzésre nem volt szükség (a kor többnyire adott, a nemek szerinti csoportosítás nem lekérdezhető). A kurzus során nyújtott teljesítményüket és aktivitásukat a Moodle rendszer által szolgáltatott logolási adatokra alapozva váltak elemezhetővé. A tesztek kitöltése során az azokon elért pontszámot, a kitöltöttséget, valamint a további próbálkozások számát vette figyelembe a kutatás. A hallgatók véleményeinek összeütköztetése a „Hallgatói Véleményezés (HalVel)” által levezényelt és közzétett kérdőívezés eredményein alapul.

A Moodle rendszeren túllépve egy saját oktatóalkalmazás fejlesztésébe kezdtem, melynek tervezési és edukációs aspektusait taglalja a dolgozat. 


\section{GAMIFIKÁLT CSAPATÉPÍTŐ ALKALMAZÁS HATÁSA A MUNKAVÁLLALÓKRA}

A kutatás során használt gamifikációs megoldás a 9M motivációs modell (ld. 2.2.6. fejezet) közül a „Munkahelyi környezet” és a „Munkahelyi kapcsolatok” elemeire kíván hatással lenni, míg az elköteleződés 9 mozgatórugója közül (ld. 2.2.7. fejezet) a vállalaton belüli szociális környezet javításában és a munkahelyi kapcsolatok kialakításában segíthet. A 2018-ban publikált kutatás (Barna \& Fodor, 2018b) fontos kérdése volt, hogy vajon a gamifikációs alkotóelemeket tartalmazó alkalmazás ösztönözte-e a munkavállalókat a rendszeres testedzés életvitelbe iktatására, illetve következetes fenntartására vagy sem. A kedvezőbb munkahelyi légkör kapcsán indított vizsgálatok végül megismétlésre kerültek, melyek a 2016. július 1-jétől kezdve és 2020. január 31-éig bezáródóan, 43 hónapot felölelően vizsgálta a Battlejungle által szolgáltatott adatokat.

\subsection{Vizsgálatba bevont felhasználók és cégek jellemzői}

\subsubsection{A kutatás alá vont résztvevők}

A felhasználókkal és a szervezetekkel kapcsolatos adatok a kutatások során anonimizált formában kerültek felhasználásra. A felhasználókkal kapcsolatba hozható személyes adatok nem kerültek átadásra, a leíró statisztikák alapját aggregált adatok adták. A szolgáltatás használói a regisztrációjukat csak felhasználási feltételek és az adatvédelmi irányelvek elfogadásával tehették meg, mely tartalmazza az általuk generált adatok vizsgálhatóságát. A vizsgált szolgáltatás üzemeltetői biztosították, hogy adatvédelmi irányelveik és adatkezelési módszerek összhangban állnak a legfrissebb GDPR ${ }^{9}$-irányelvekkel.

A Google Analytics szolgáltatás segítségével feltérképezhetővé váltak a Battlejungle felhasználói. Mivel a Google Analytics maximum három-hónapos időtávot enged aggregálni, ezért az általa kinyerhető leíró statisztikák 3-hónapos időszakok összegzésével

\footnotetext{
${ }^{9}$ General Data Protection Regulation - Általános Adatvédelmi Rendelet
} 
kerültek elemzésre, melyeket 2017. április 1-jétől követett nyomon a Google szolgáltatása. Az adatok alapját azon felhasználók által indított munkamenetek képzik, akik a vizsgált időszak kezdetekor már rendelkeztek fiókkal a szolgáltatásban, vagy időközben regisztráltak rá.

\section{Lokalizáció}

Az alkalmazás kereskedelmi bevezetése többnyire Magyarországra korlátozódott, így az adott időszakban a munkamenetek száma láthatóan itt volt a legnagyobb (3352 db). A cég webes hirdetéseinek célországai főként az európai országok és az USA, ily módon a második legtöbb munkamenettel bíró ország az USA (1067), majd őt követi Németország (802), az Egyesült Királyság (560) és Franciaország (237). Az első 10 között szerepel még a webes hirdetési célterületen kívül eső Ausztrália (42) és Új-Zéland (28) (Barna \& Fodor, 2018b). A 2018-19-es évek trendjeit tekintve továbbra is a magyar piac szereplőinek munkamenetei dominálták a szolgáltatás használatát, az USA-beli cégek egyre kisebb arányban szerepeltek, helyüket európai országok vállalati vették át, úgymint Németország, Lengyelország és Svájc. A 17. ábra szemlélteti a szolgáltatás belső oldalait használó felhasználók által indított munkamenetek eloszlásának változását országuk szerinti bontásban. Az ábrán csak azok az országok szerepelnek, melyek legalább 3 külön 3-hónapos vizsgálati időpontban legalább 10 munkamenetet indítottak, és a teljes vizsgálati időszakban legalább 100 indított munkamenettel rendelkeztek. Megfigyelhető, ahogyan a Magyarországon kívüli európai vállalatok időről időre nagyobb és színesebb aktivitást mutattak (jellemzően az év első negyedében), ám az év többi részében fokozatosan veszítettek részesedésükből. 


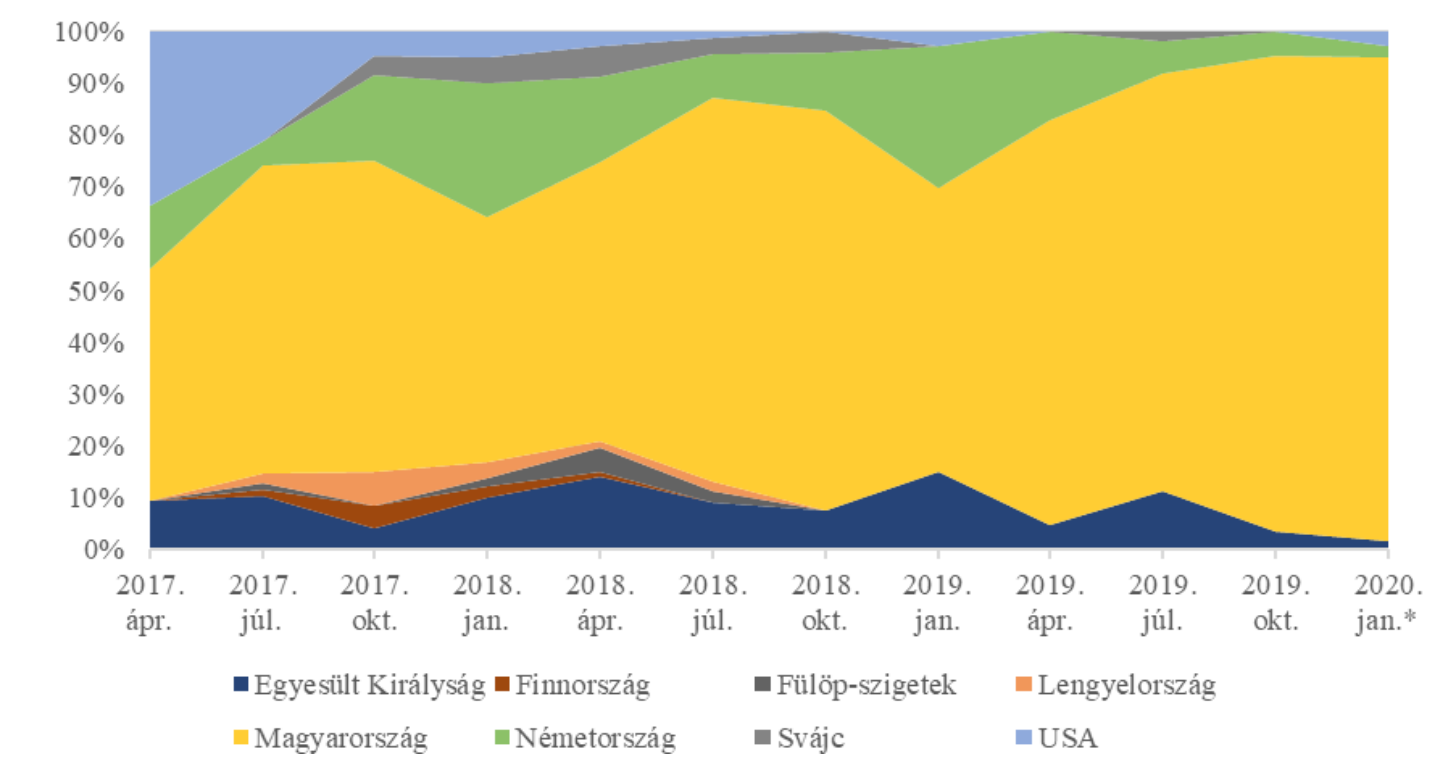

* 1-havi érték alapján számított arányszámok

17. ábra: A fiókkal rendelkező felhasználók eloszlásának változása országok szerint bontásban (Saját ábra)

\section{Demográfia}

A fiókkal rendelkező felhasználók életkor szerinti eloszlását tekintve (18. ábra $\boldsymbol{A}$ panel) a fiatal felnőttek korosztálya képezi a felhasználóbázis jelentősebb részét, 53-64\%-uk életkora tehető 25 és 34 év közé. A második legerősebb korosztály a 35-44 év közöttiek, ök 19-30\%-ban fedték le a populációt. A vizsgálati időszak alatt a pályakezdők aránya 10-17\% körül mozgott, míg a 45-54 évesek aránya maximum 6\%-ig kúszott fel.

Nem

18. ábra $\boldsymbol{B}$ panelje lévő a felhasználók nemek szerinti megoszlás és annak változását takarja. Többségében férfiakból áll a felhasználói bázis, kiknek aránya a vizsgálat elején még 72,9\%-ra rúgott, és a nők csak egynegyedét tették ki $(27,1 \%)$ ennek (Barna \& Fodor, 2018b), ám az idő előrehaladtával ez a különbség fokozatosan szükült, hosszabb időn keresztül közel 10\%-os eltérés mutatkozott a két tábor között. Ezek az értékek - a kezdeti nagy szakadéktól eltekintve - összhangban állnak az átlagos játékosok nemenkénti megoszlásával (ld. 2.3 fejezet). 
A Felhasználók életkor szerinti megoszlása

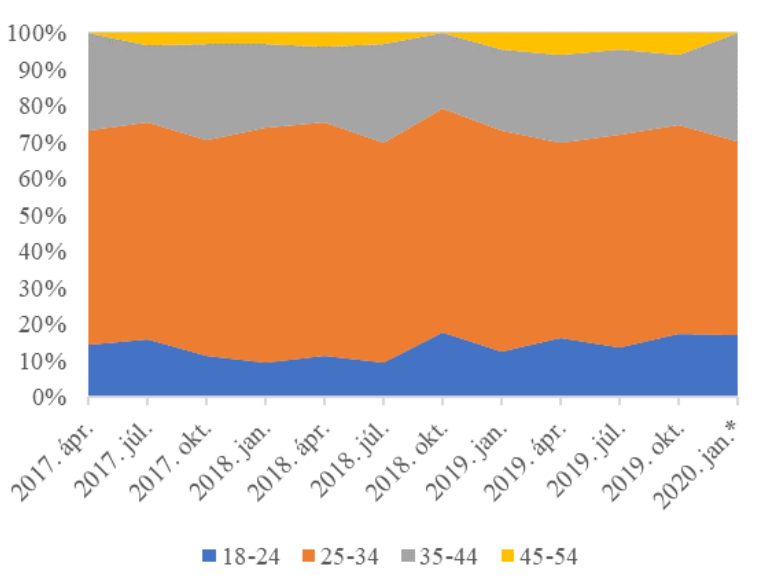

* 1-havi érték alapján számított arányszámok
B Felhasználók nem szerinti megoszlása

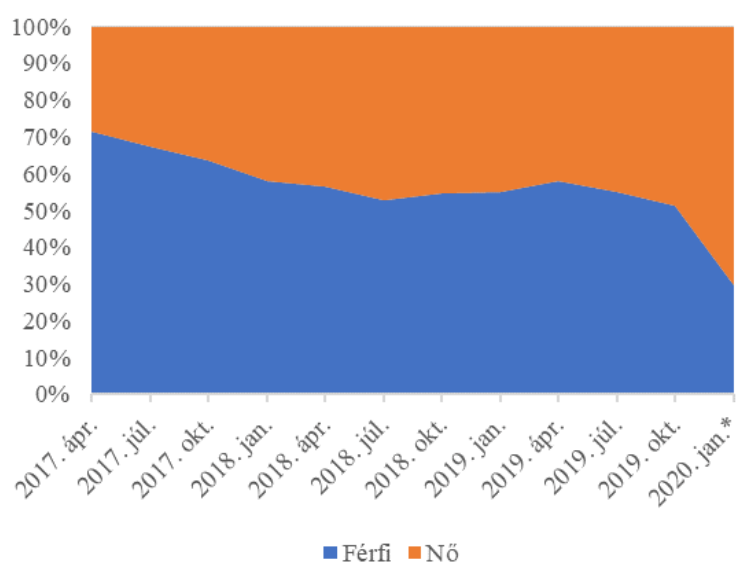

18. ábra: 2017. április 1. és 2020. január 31-e között belépett felhasználók életkor (A) és nem (B) szerinti megoszlásának változása (Saját ábra)

\section{A résztvevők munkahelyeinek piacon belüli szegmense}

A felhasználók munkahelyeinek kategóriáit vizsgálva (a Google Analytics által szolgáltatott adatok alapján) elmondható, hogy közel egyenlő arányban képviseltetik magukat a különböző utazási $(8,7 \%)$ és a pénzügyi szolgáltatások területén dolgozók $(8,4 \%)$. Ezenkívül még az autóiparban (4,3\%), és a szoftverfejlesztéssel foglalkozók (3\%) részvétele számottevő. (Barna \& Fodor, 2018b)

\subsubsection{A kutatásban vizsgált szervezetek}

A Battlejungle szolgáltatás használatakor a felhasználóknak először létre kell hozniuk egy szervezetet, melynek keretei között ki tudnak majd írni különféle eseményeket, versenyeket, kihívásokat, és amelybe munkatársakat (további felhasználókat) tudnak felvenni, illetve meghívni. (Battlejungle, 2019)

A kutatásba azok a szervezetek kerültek be, amelyek a vizsgálati időszakban legalább 10 fővel rendelkeztek, és legalább 1 darab versenyhez, kihíváshoz vagy eseményhez köthető, annak célját elősegítő teljesítményalapú aktivitást váltottak ki (pl. meccs lejátszása, futóeredmény rögzítése, eseményen való részvétel) (Barna \& Fodor, 2018b). Az előbbi kritériumok alapján 51 szervezet képezte részét a vizsgálatnak. Ezek létszáma 10 és 385 fö között mozgott, és összesen 3970 felhasználót foglal magába. Az 51 szervezetből 25 a Battlejungle üzemeltetői közvetlen megkeresése után kezdték el az alkalmazást használni 
(3386 fö), míg huszonhat szervezet (584 fö) organikus módon, azaz hallomás, hirdetés vagy PR-cikk kapcsán kezdte el használni a szolgáltatást.

A 19. ábra $\boldsymbol{A}$ panelján a szervezetek területi megoszlása látható, ami némi különbséget mutat az összes felhasználó lokalizációs eloszlásával. Ahogy a felhasználók esetében, a szervezetek döntő többsége is magyarországi székhelyü (29 db), köszönhetően az erős hazai személyes megkeresésnek. Noha a felhasználók körében a németországi tartózkodás jelentős arányt képviselt, a cégek között csak $1 \mathrm{db}$ müködött német földön. A szervezetek közel ötöde (9 db) az USA-ban müködik, 12\%-uk (6 db) az Egyesült Királyságban tevékenykedik. Az Egyéb kategóriába kerültek Németország mellett Ausztrália, Ausztria, Oroszország, Szingapúr, Svájc és Új-Zéland egy-egy vállalattal.

Az 51 szervezet iparági besorolásáról elmondható (19. ábra $\boldsymbol{B}$ panel), hogy főként az IT és a tanácsadás területén mozgó vállalatok fogékonyak egy ilyen jellegü online, közösségépítő szolgáltatás használatára.
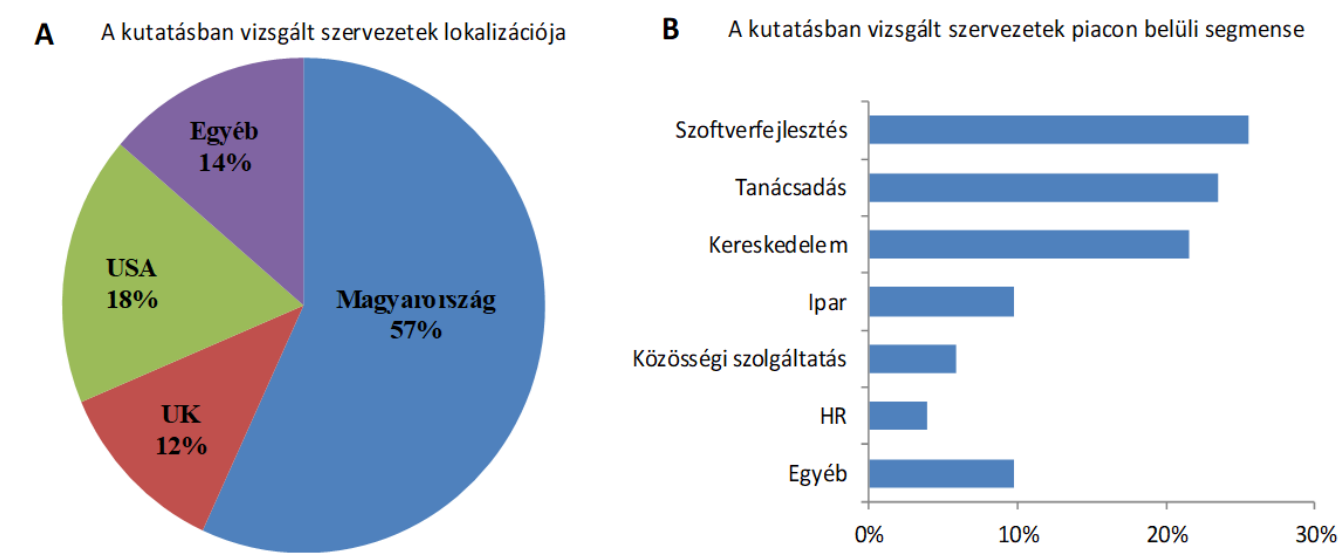

19. ábra: A vizsgálatba bevont 51, legalább 10 fővel rendelkező szervezet lokalizáció és iparág szerinti besorolása (Saját ábra)

A szolgáltatást tartósan használó szervezetek és a felhasználók munkahelyeinek piaci besorolása között eltérés mutatkozik. Míg a szoftverfejlesztés mindkettő csoport esetében megjelenik, addig pl. az autógyártás csak az egyedi felhasználók oldalán jelentkezik. Ennek oka lehet, hogy az egyéni felhasználók esetében gyakran több iparágat is feltüntet a Google Analytics, hiszen egy vállalkozás különböző szektorokban is dolgozhat, míg a kutatás keretein belül a vizsgált szervezeteket egyértelmü kategóriát kaptak. (Barna \& Fodor, 2018b) 


\subsection{A szervezetek által indított bajnokságok}

A vizsgált cégek 276 versenyt indítottak 53 különböző sportágban, amelyek során 3469 mérkőzést játszottak le, és 65496 egyéni teljesítmény bejelentése történt meg. Megszervezésük és levezénylésük körülményességének kategorizálása az alábbi ötfokozatú skála (Barna \& Fodor, 2018b) segítségével történt:

1. Mikrotételü beszerzést, vagy már meglévő mindennapos, egyszerű eszközt igényel.

2. Kistételü beszerzést igényel a sport, a bajnokság bárhol lebonyolítható.

3. Közepes tételü beszerzést igényel a sport, és kisméretü belső helyigényt jelent a bajnokság.

4. Közepes tételü beszerzést igényel a sport, közepes helyigényü a bajnokság, és kisebb csapatok összetoborzása szükséges.

5. Nagy tételü beszerzést igényel a sport, nagy helyigényü a bajnokság, és nagy létszámú csapat toborzása szükséges.

A bajnokságok körében csak néhány esetben (14 db) fordul elö 4-es vagy 5-ös körülményességgel bíró eset (tenisz, futball stb.). A kevésbé körülményes választások közül az asztali tenisz, a csocsó és a könnyedebb hangvételü árkád játékok (pl. tésztatorony-építés) a legnépszerübbek (ld. 5. táblázat), őket követik a hagyományos sportok, úgymint a futás és a biciklizés. Az adatokból kiolvasható, hogy a vállalatok az olyan sporteseményt preferálják, mely inkább szórakoztató hangvételü, közismert tevékenység, és emellett nem igényel nagy összegü ráfordítást (Barna \& Fodor, 2018b).

\begin{tabular}{|c|c|c|}
\hline Sport neve & Körülményesség & Darab \\
\hline Asztalitenisz & 3 & 67 \\
\hline Csocsó & 3 & 22 \\
\hline Ügyességi játékok & 2 & 19 \\
\hline Futás & 2 & 18 \\
\hline Vegyes sportok & 3 & 15 \\
\hline Biciklizés & 3 & 14 \\
\hline
\end{tabular}

5. táblázat: A 6 legnépszerübb sport a vizsgált szervezetek által indított bajnokságok alapján (Saját szerkesztés) 


\subsection{Felhasználói visszajelzések}

A Battlejungle szolgáltatásban több helyen is lehetőség adódik visszajelzéseket adni (Battlejungle, 2019). A visszajelzési rendszer a vizsgálati idő első félévében még nem volt elérhető, az 2017. február 1-jétől képezi részét a szolgáltatásnak és vált elérhetővé a felhasználók számára. A feltett kérdést befolyásolja, hogy az adott felhasználó mióta használja a szolgáltatást, milyen sportágú bajnokságokon vett részt, mikor válaszolt meg hasonló kérdést (Barna \& Fodor, 2018b). A vizsgált szervezetek tagjaitól összesen 6104 darab kérdésmegválaszolás érkezett. A feltett kérdések az alábbi öt témakörre bonthatóak (Barna \& Fodor, 2018b):

- Munkahelyi légkör változása

- A szervezet tagjaival történő kapcsolatok száma és minősége

- Sportolások gyakorisága

- Eredménybejelentés utáni érzés

- A szolgáltatással kapcsolatos vélemény

A kutatásban az első négy témakörbe tartozó kérdések vizsgálata történt meg. A kérdések egyenként, a szolgáltatás felületének több pontján kerülnek megjelenítésre, a válaszadás pedig minden esetben önkéntes. A felületen történő visszajelzésre leghamarabb a regisztrációt követő 2 hét letelte után kerülhet sor. A korlátozás indoka, hogy a rendszert még nem ismerő felhasználók ne tudjanak 1-2 alkalomnyi használat után olyan kérdésekre válaszolni, mely a szolgáltatás által okozott változást hivatott mérni. A változást kutató kérdéseket (típustól függően) 2-3 hét múlva a felhasználó újra meg tudja válaszolni. (Barna \& Fodor, 2018b)

A feltett kérdések tartalmát, kategóriáját az 1. mellékletben található 16. táblázat tartalmazza.

\subsection{Felhasználók kategorizálása viselkedés alapján}

Számos személyiségmodell lelhető fel a viselkedéselemzés témakörében, többek között a Myers-Briggs Típuselmélet (MBTI), az Öt-faktor Modell (FFM), a Bartle-féle játékoskategorizálás vagy épp a BrainHex modell. A felhasználók kategorizálása a BrainHex 
modell alapján történt (ld. 2.3.3. fejezet), mely alapvetően egy játékostipológia, ám számos kutatás használta már játékkal és gamifikációval kapcsolatos tanulmányokban (Orji, et al., 2013) (Busch, et al., 2016) (Lavoué, et al., 2018) (Orji, et al., 2017). A modell kimondja, hogy nem lehet egy felhasználót kizárólagosan egy típusba besorolni, hanem csak a játékos elsődleges kategóriája adható meg. A játékostípus azonosításának előnye, hogy a hozzárendelt típus felhasználható a játékosok egy adott tevékenységre vagy ingerre adott reakciójának megbecslésére, és meghatározza (a környezeti és fejlesztési limitációk mellett), miként lehet kontrollálni, ellenőrizni és/vagy motiválni a felhasználót a kívánt müvelet végrehajtására. A BrainHex modell 7 játékostípust különböztet meg: Teljesítő, Győztes, Vakmerő, Lángész, Felfedező, Társasági és Túlélő.

A besoroláshoz 11 db használatalapú karakterisztika került felhasználásra, melyek a vizsgált szolgáltatásból lettek kinyerve, és amelyek felölelik a 2016. július 1-je és 2020. január 31-e közötti időszakot. A karakterisztikákat a 6. táblázat tartalmazza.

\begin{tabular}{|c|c|c|}
\hline \multirow{2}{*}{ 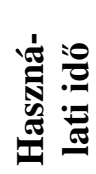 } & period $(\mathrm{A} 1)$ & $\begin{array}{l}\text { Használati idő napokban kifejezve (A regisztráció ideje } \\
\text { és az utolsó bejelentkezés között eltelt napok száma.) }\end{array}$ \\
\hline & $\operatorname{logins}(\mathrm{A} 2)$ & Bejelentkezések száma \\
\hline \multirow{3}{*}{ 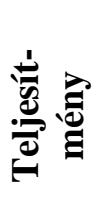 } & point (A3) & Gyüjtött pontok mértéke \\
\hline & level (A4) & Elért szint \\
\hline & badges (A5) & Gyüjtött jelvények száma \\
\hline \multirow{3}{*}{ 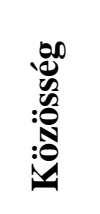 } & like (A6) & Bejegyzésekre adott pozitív reakciók (“like”) száma \\
\hline & post (A7) & Létrehozott bejegyzések száma \\
\hline & comment (A8) & Bejegyzésekhez füzött megjegyzések száma \\
\hline \multirow{3}{*}{ 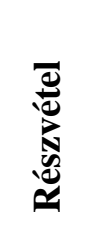 } & individual (A9) & Egyéni versenyeken való részvétel száma \\
\hline & team $(\mathrm{A} 10)$ & Csapatos versenyeken való részvétel száma \\
\hline & social event (A11) & $\begin{array}{l}\text { Közösségi események való részvétel száma (pl. szerve- } \\
\text { zett önkénteskedés) }\end{array}$ \\
\hline
\end{tabular}

6. táblázat: Használatalapú karakterisztikák listája (Fodor \& Barna, 2020) alapján

A használatalapú tulajdonságok mellett további bemenetként szolgáltak a visszajelzési kérdésekre adott válaszok. A felhasznált kérdések két témakörre bonthatóak: (Fodor \& Barna, 2020) 
- Motivációval kapcsolatos kérdéskör (7. táblázat)

- Jólléttel kapcsolatos kérdéskör (8. táblázat), mely taglalja

○ a munkahelyi légkörben bekövetkezett változást,

○ a munkavállalók között kialakult kapcsolatok mennyiségének és minőségének változását,

○ a sportolási gyakoriság változását.

\begin{tabular}{|l|l|}
\hline Rövidítés & \multicolumn{1}{c|}{ Kérdés } \\
\hline LB & $\begin{array}{l}\text { Milyen gyakran tekinti meg a fö ranglista oldalát (ami minden felhasználót tar- } \\
\text { talmaz)? }\end{array}$ \\
\hline mini LB & $\begin{array}{l}\text { Milyen gyakran tekinti meg a kicsi ranglistát, ami az Irányítópult oldalán talál- } \\
\text { ható (ami csak a szomszédos felhasználókat mutatja)? }\end{array}$ \\
\hline Level-1 & $\begin{array}{l}\text { Tetszenek és motiválja önt a játékosszintek állatos témái (elnevezés és iko- } \\
\text { nok)? }\end{array}$ \\
\hline Level-2 & Meg szokta nézni a saját és más játékos szintjét? \\
\hline Badge & Tetszenek és motiválják önt a Jelvények? \\
\hline Point & $\begin{array}{l}\text { Motiválja önt a Karma }{ }^{10} \text { abban, hogy részt vegyen az aktivitásokban és a kihí- } \\
\text { vásokban? }\end{array}$ \\
\hline Profile & Milyen gyakran látogatja meg más játékos profiloldalát? \\
\hline
\end{tabular}

7. táblázat: Motivációval kapcsolatos kérdések (Fodor \& Barna, 2020)

\begin{tabular}{|l|l|}
\hline Rövidítés & \multicolumn{1}{|c|}{ Kérdés } \\
\hline Atm-1 & Hogyan változott a szervezeténél a légkör a szolgáltatás bevezetése óta? \\
\hline Atm-2 & Hogyan változott a szervezeténél a légkör az elmúlt 30 napban? \\
\hline Rel-1 & $\begin{array}{l}\text { Hány egyáltalán nem vagy kevésbé ismert emberrel ismerkedett meg a Battle- } \\
\text { jungle-ön keresztül az elmúlt 30 napban? }\end{array}$ \\
\hline Rel-2 & Jobb-e a kapcsolata azokkal az emberekkel, akikkel már játszott együtt? \\
\hline Sport-1 & Többet sportol a szolgáltatás használata óta? \\
\hline Sport-2 & $\begin{array}{l}\text { Előfordult-e már, hogy [adott sportból] többet üzött csak azért, hogy a szolgál- } \\
\text { tatásban rögzítse az eredményét? }\end{array}$ \\
\hline
\end{tabular}

8. táblázat: Jólléttel kapcsolatos kérdések (Fodor \& Barna, 2020)

A kérdések javarészénél a felhasználó 5 vélemény közül választhatta ki, melyek skálaalapon kapcsolódtak egymáshoz. A lehetőségek közül csak 1-et lehetett választani, a kérdés megválaszolása minden esetben opcionális, szöveges véleménynyilvánításra nem adódott lehetőség. A kérdések egy előre meghatározott kérdésbankból kerülnek kiválasztásra

\footnotetext{
${ }^{10}$ A vizsgált szolgáltatásban a pontokat Karmának nevezik.
} 
alapul véve a felhasználó eddigi tevékenységeit, az aktuálisan megnyitott interfészt, valamint a hasonló jellegű kérdések kitöltöttségét. (Fodor \& Barna, 2020)

\subsubsection{Elkötelezett felhasználók behatárolása}

A kutatás egyik célja a hosszútávú elköteleződés vizsgálata, ily módon a besoroláshoz a szolgáltatás elkötelezett felhasználóinak behatárolása szükséges. A populációból első lépésként az új felhasználók kerültek leválasztásra. Felhasználói érettségük a regisztrációjuktól számított használati időtartamból eredeztethetőek, ahol elkötelezettnek azt a felhasználót tekintettük, aki a legutolsó belépésekor már legalább 100 napja csatlakozott a szolgáltatáshoz. Mivel a választott határ esetleges, ezért megvizsgáltuk a határ elmozgatásával járó többlet/lemorzsolódott populációméretet. A 9. táblázat megmutatja, hogy a tízes lépésekben vett vágási határok (70 és 120 fö között) hány fő „új felhasználót” eredményez. Az elsődleges érettségi határ végül 100 napban került megállapításra, s a táblázat tartalmazza az ehhez a határhoz mért különbséget a többi vágási lehetőség esetén. (Fodor \& Barna, 2020)

\begin{tabular}{|c|c|c|}
\hline $\begin{array}{c}\text { Regisztráció } \\
\text { óta eltelt idő } \\
\text { (nap) }\end{array}$ & $\begin{array}{c}\text { „Új felhasználók" } \\
\text { száma }\end{array}$ & $\begin{array}{c}\text { „Új felhasználók" } \\
\text { számában bekövet- } \\
\text { kezett változás }\end{array}$ \\
\hline $0-70$ & 73 & -169 \\
\hline $0-80$ & 180 & -110 \\
\hline $0-90$ & 242 & -48 \\
\hline $0-100$ & 290 & 0 \\
\hline $0-110$ & 302 & 12 \\
\hline $0-120$ & 322 & 32 \\
\hline
\end{tabular}

9. táblázat: „Új felhasználók” számának alakulása a regisztráció óta eltelt idő függvényében (Fodor \& Barna, 2020)

A populáció mértékében a kiválasztott 100-as érték előtti sávokban jelentős bővülés állapítható meg, ám a 100-napos határ felett már csak 4-10\%-os emelkedés tapasztalható. (Fodor \& Barna, 2020)

Szolgáltatáshasználat szempontjából azon hosszútávú felhasználókat tekintettük elkötelezettnek, akik egy 60-napos periódus alatt legalább 5x tértek vissza a felületre. A definíció eme két tulajdonsága szintén esetleges meghatározású, ezért megvizsgáltuk, miként alakulna az elkötelezett felhasználók száma egyéb, tízesléptékü időtartamú besorolás 
esetén, valamint gyakoribb visszatérés megkövetelésekor (Fodor \& Barna, 2020). Az alpopulációban történő változás mértékét mutatja a 10. táblázat.

\begin{tabular}{|c|c|c|c|}
\hline $\begin{array}{c}\text { „Tényleges” } \\
\text { használati idő- } \\
\text { tartam (nap) }\end{array}$ & \multicolumn{3}{|c|}{ Új ,nem elkötelezett” felhasználók száma } \\
\cline { 2 - 4 } & $\mathbf{7}$ visszatérés & $\mathbf{2 6}$ visszatérés & $\geq 7$ visszatérés \\
\hline $0-60$ & - & 77 & 139 \\
\hline $0-70$ & 8 & 141 & 198 \\
\hline $0-80$ & 15 & 237 & 292 \\
\hline $0-90$ & 21 & 276 & 327 \\
\hline $0-100$ & 25 & 316 & 363 \\
\hline $0-110$ & 33 & 363 & 405 \\
\hline $0-120$ & 37 & 424 & 462 \\
\hline
\end{tabular}

10. táblázat: Új „nem elkötelezett” felhasználók számának alakulása (Fodor \& Barna, 2020)

Amennyiben a „tényleges” használati időtartam szintjével szembeni elvárást duplájára is emeljük, mindössze 37 fö kerülne át az egyébként közel 4600 fős „,nem elkötelezett” kategóriába. A visszatérések számának és a használati időtartam mértékének növelésével is maximum 10\%-os populációnövekedést jelentene a „,nem elkötelezett”-ek körében. (Fodor \& Barna, 2020)

A fentiek alapján a felhasználók 3 kategóriába sorolhatóak be:

- „új felhasználók”: kevesebb mint 100 napja regisztráltak;

- „,nem elkötelezett felhasználók”: több mint 100 napja regisztráltak, ám ténylegesen nem használták a szolgáltatást 60 napig, avagy 5-nél kevesebbszer tértek viszsza;

- „elkötelezett felhasználók”: több mint 100 napja regisztráltak, legalább 60 napig használták a szolgáltatást, mely idő alatt legalább 5x tértek vissza.

A felosztás során a teljes populáció (N=6076) 4,8\%-a számít „új felhasználó”-nak (290 fö), 19,4\%-uk „elkötelezett felhasználó”-nak (1178 fö), és 75,8\%-uk ,nem elkötelezett felhasználo’"-nak (4608 fö). (Fodor \& Barna, 2020)

Az „új felhasználók” esetében az átlagos napi szolgáltatáshasználat (pl. egy napra eső bejelentkezések száma) és a szociális aktivitások (pl. like-ok száma) szignifikánsan magasabbak, mint a másik két csoport esetében. Az átlagos szolgáltatáshasználatot tekintve megfigyelhető volt, hogy a mértéke az első három hónapban lefeleződött (Fodor \& Barna, 2020). A jelenség lehetséges magyarázata lehet a kezdeti újdonság és kíváncsiság érzete, 
ezt a törvényszerűséget támasztják alá más, eltérő esetekben végzett tanulmányok is (Farzan, et al., 2008) (Koivisto \& Hamari, 2014).

Noha a játékostípusok vizsgálatát csak az „elkötelezett” felhasználókon lehet érdemben elvégezni, érdemes szólni a „nem elkötelezett” csoportról is. A közel 76\%-os arány meglehetősen magasnak tünik, úgyhogy először ennek okát kerestük. Bejelentkezésüket vizsgálván kiderült, hogy közel 54\%-uk a regisztrációt követően már egyszer sem tért vissza. Lehetséges magyarázata lehet a szolgáltatás bevezetésekor történő, csatlakozást hirdető szervezeti felhívás, mely során olyan felhasználók is csatlakoznak, akik alapvetően nem érdeklődnének a szolgáltatás iránt. Ha a vissza-nem-tért felhasználókat (2495fö) leválasztjuk a „,nem elkötelezett”-ek csoportjától, a tényleges használattal bíró, ám lemorzsolódottak aránya a 74,8\%-ról (4608 fó) lecsökken 59,0\%-ra (2113fö). A 20. ábra szemlélteti a használati idő elteltével a kumulált átlagos szervezeti lemorzsolódás arányát. (Fodor \& Barna, 2020)

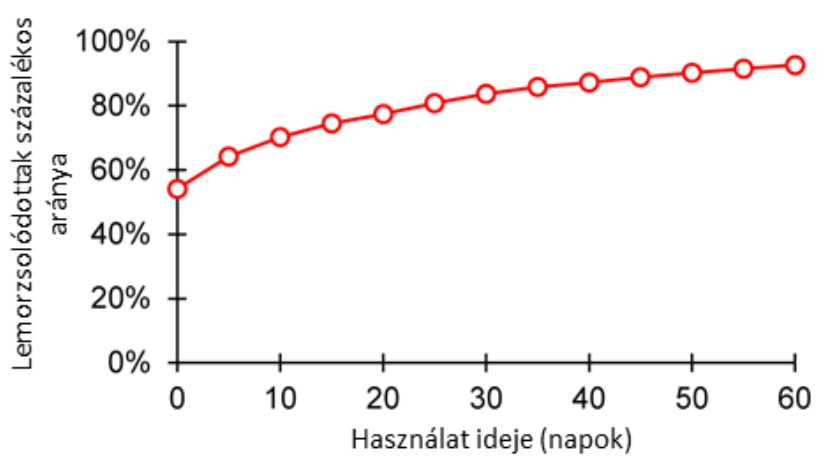

20. ábra: Lemorzsolódott felhasználók arányának változása a használati idő függvényében (Fodor \& Barna, 2020)

A 3 populáció eloszlása statisztikai tesztelés alá kerültek annak érdekében, hogy különbözőségük biztosított legyen. A 6. táblázatban található karakterisztikákat alapul véve Kolmogorov-Smirnov teszteléssel bizonyítottá vált, hogy a 11 karakterisztika esetében a 3 populáció szignifikáns eloszlásbéli különbséget produkált, ily módon a 3 populáció statisztikailag különbözőek, a felvázolt szétválasztási szabályok megfelelőnek bizonyultak. A viselkedési minták vizsgálata a továbbiakban az „elkötelezett” csoport tagjain alapul. (Fodor \& Barna, 2020) 


\subsubsection{Viselkedési minták azonosítása}

Összevonó Hierarchikus Klaszterképzés (Agglomerative Hierarchical Clustering - AHC) útján - Pearson-féle korrelációs együttható használatával - viselkedési azonosságokat keresve csoportokat képeztünk, melyhez a használatalapú karakterisztikák (ld. 6. táblázat) képezték az algoritmus inputját (Fodor \& Barna, 2020). Az attribútumokra vonatkozó statisztikai összegzést tartalmazza az alábbi táblázat (11. táblázat):

\begin{tabular}{|l|c|c|c|c|c|c|c|c|c|c|c|}
\hline & A1 & A2 & A3 & A4 & A5 & A6 & A7 & A8 & A9 & A10 & A11 \\
\hline Min. & 61 & 5 & 0 & 1 & 0 & 0 & 0 & 0 & 0 & 0 & 0 \\
\hline Max. & 1181 & 1141 & 16106 & 15 & 52 & 137 & 29 & 106 & 45 & 6 & 46 \\
\hline Átlag & 256,6 & 32,6 & 1006,5 & 3,9 & 3,1 & 1,4 & 0,4 & 1,1 & 2,8 & 0,5 & 3,3 \\
\hline Szórás & 218,1 & 65,1 & 1305,6 & 2,0 & 4,7 & 6,7 & 1,7 & 5,2 & 4,1 & 0,9 & 4,2 \\
\hline
\end{tabular}

11. táblázat: „Elkötelezett” felhasználók használatalapú karakterisztikáinak statisztikai összegzése (Fodor \& Barna, 2020)

$\mathrm{Az}$ AHC algoritmus egyik előnye, hogy nem kell előre meghatározni a klaszterek számát. Az AHC metódusa a csoportosítandó objektumok közti közelséget veszi alapul, emiatt megfelelően alkalmazható szabályos és szabálytalan alakú klaszterekre. Az algoritmus - mely a Ward-módszert alkalmazva építi fel a klasztereket, és az elemek között euklideszi távolságot vett alapul - egyik „terméke” az alábbi dendrogram (21. ábra), amely bemutatja az adatok csoportosításának lépéseit, melynek végén 4 klasztert különböztetett meg egymás-

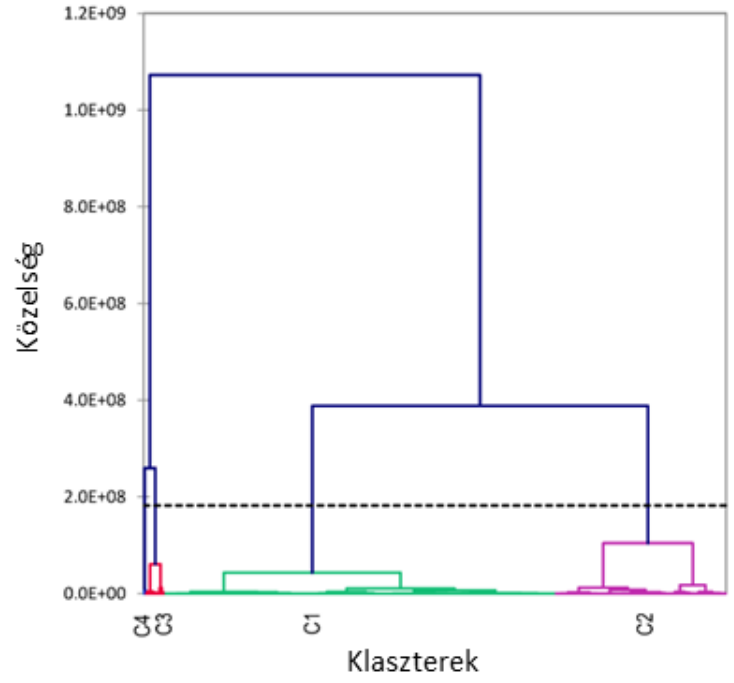

21. ábra: „Elkötelezett” felhasználók karakterisztikái alapján végzett AHC típusú klaszterezés dendrogramja (Fodor \& Barna, 2020) tól. (Fodor \& Barna, 2020)

Az első klaszter (class-1) 790 egyént foglal magába, a második klaszter (class-2) 344-et, a harmadik (class-3) 40-et, míg a negyedik (class-4) 4 föt. Az optimális osztályozási értékek varianciabomlása $16,8 \%$ a csoporton belüli variancia esetén, míg a csoportok közötti variancia 83,2\%, és a kofenetikus korreláció 0,76. (Fodor \& Barna, 2020) 
Elöször a class-4 csoporttal érdemes foglalkozni, mely az „elkötelezett” felhasználók mindössze $0,3 \%$-át foglalja magában, ám gyüjtött pontjaik átlaga több mint kétszere bármely más csoporténak, valamint felülmúlják a többieket többek között a napi bejelentkezések számában, valamint közösségi funkciók használatában is. Az általuk írt kommentek szövegbányászati vizsgálata során kiderült, hogy eme felhasználók szervezői szerepkört töltenek be, emiatt „húzó emberekként” és eseményszervezőként kiugróan magas részvételt tanúsítanak. Mivel a class-4 csoport tagjait nemcsak a személyes érdeklődésük és egyéni céljaik vezetik, ezért a további elemzésekben már nem szerepelnek. (Fodor \& Barna, 2020)

A class-1 csoportról elmondható, hogy közösségi szempontból közepesen aktívak (ld. 22. ábra), tetszésüket kinyilvánítják (like-ok formájában), ám szöveges tartalmat (bejegyzést, megjegyzést) ritkán hoznak létre, ök vesznek részt a három csoport közül a legkevesebb versenyen és eseményen, valamint jelvényszerzésben is le vannak maradva. (Fodor \& Barna, 2020)

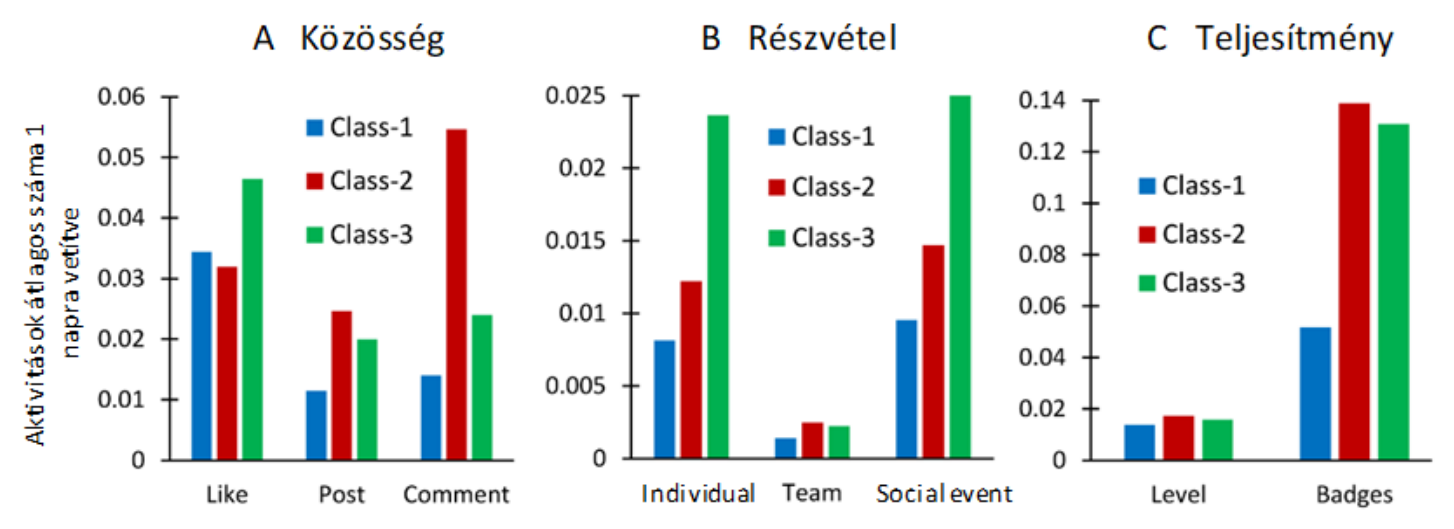

22. ábra: Adott aktivitás átlagos napi mértéke az „elkötelezett” felhasználókból képzett osztályok esetén (Fodor \& Barna, 2020)

A csoportok jobb megértéséhez megvizsgáltuk a motivációval és jólléttel kapcsolatos kérdésekre (ld. 7. táblázat és 8. táblázat) adott értékelésüket. Érdekesség, hogy míg használati szokásukat tekintve marginális különbségek is adódtak, addig a visszajelzési kérdések esetében kevésbé jól elhatárolható tulajdonságokat lehet megállapítani, ám ettől még segíthetnek a csoportok jobb megértésében (23. ábra). A visszajelzésekböl kiderül, hogy a class-1 nagy érdeklődést mutat olyan funkciók iránt, melyek a játékosok közötti teljesítményösszehasonlítást szolgálják, például a ranglista, a saját és a többi játékos szintje, többiek profilja. Ezek alapján a BrainHex modellre illeszkedvén a „Győztesek” besorolást 
kapták (Fodor \& Barna, 2020). Megjegyzendő, hogy a klaszter nagyszámú populációja noha a kategória valóban az egyik legnépszerübb viselkedési típus (ld. 2.3.3. fejezet) -, valamint a jellemzők nem kellően radikális mivolta miatt a „Győztesek” besorolás eme nagyméretű csoport egy leginkább kivehető, ám nem egyedüli jelzője. Eme kutatás keretében viszont a klaszter további bontására nincs lehetőség, így a teljes csoport a leginkább megnevezhető tulajdonságjegyei alapján került bekategorizálásra.

A class-2 tagjai jelentkeztek be és vettek részt csapatalapú versenyeken a legtöbbször, az ő átlagos játékosszintjük a legmagasabb, és ők gyüjtötték egységnyi idő alatt a legtöbb jelvényt is. Szociálisan kifejezetten aktívak, nagy számú bejegyzést és kommentet írnak. Ha figyelembe vesszük a visszajelzési kérdésekre adott válaszaikat (23. ábra), kiderül, bevallásuk szerint ennek a csoportnak a tagjai ismerkedtek meg a legtöbb egyáltalán nem vagy kevéssé ismert emberrel, valamint ők ítélik meg a legjobbnak a munkahelyi környezetet. Ezek a felhasználók szeretnek egymással kapcsolatba kerülni és összedolgozni egy feladat leküzdése érdekében. Összesítvén a megállapított tulajdonságaikat, a BrainHex modell kapcsán ők alkotnák a „Társasági” kategóriát. A felhasználók 30\%-a tartozik ebbe a kategóriába. (Fodor \& Barna, 2020)
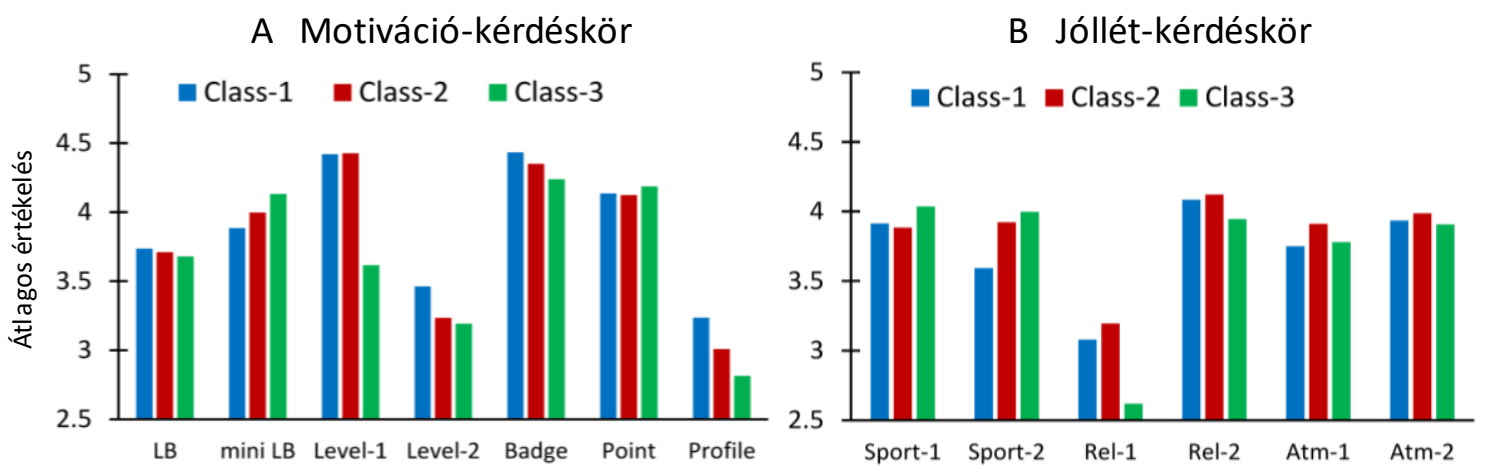

23. ábra: Az „elkötelezett” felhasználók által a visszajelzési kérdésekre adott értékelések átlagos mértéke, osztályonkénti bontásban (Fodor \& Barna, 2020)

Válaszadási arányok: Sport-1 19,86\%; Sport-2 20,46\%; Rel-1 7,30\%; Rel-2 6,37\%; Atm-1 16,13\%; Atm-2 15,62\%; LB 6,28\%; mini LB 5,94\%; Level-1 6,37\%; Level-2 6,03\%; Badge 5,86\%; Point 6,45\%; Profile 11,88\%. (A röviditésekhez tartozó kérdések megtekinthetőek a 7. táblázatban (Panel A) és a 8. táblázatban (Panel B).)

A class-3 csoportba tartozó felhasználók vettek részt a legtöbb versenyen és szociális eseményen, valamint közel ugyanannyi jelvényt szereztek, mint a class-2 tagjai (ld. 22. ábra). Eme csoport tagjai (alapul véve a motivációkról szóló visszajelzéseket a 23. ábra) a többieknél is még inkább motiválja őket a pontok mértéke, a relatív rangsor jobban 
érdekli őket, mint az össznépi ranglista, valamint esetükben a szolgáltatás nagyobb hatással bírta rá őket arra, hogy többet sportoljanak. Ezzel szemben a kapcsolati háló kiterjesztése nem tekinthető a csoport erősségének. Ezen megállapítások alapján a class-3 a BrainHex modell szerinti „Teljesitők” kategóriájának feleltethetőek meg. Jelen kutatásban az ő csoportjuk 3\%-ot tesz ki. (Fodor \& Barna, 2020)

Az összegyüjtött attribútumok közti kapcsolat erősségének vizsgálatához a Pearson-féle korrelációs együttható került felhasználásra, melynek hőtérképét a 24. ábra szemlélteti. Kifejezetten erős kapcsolat $(0,9)$ mutatkozik az egyéni versenyeken történő részvétel és a szociálisan események való megjelenésszám között. Ennek egy lehetséges indoka lehet, hogy a class- 1 csoport tagjai, akik szeretik az egyéni kihívásokat, kívánatos lehet számukra a szociális eseményeken való részvétellel járó

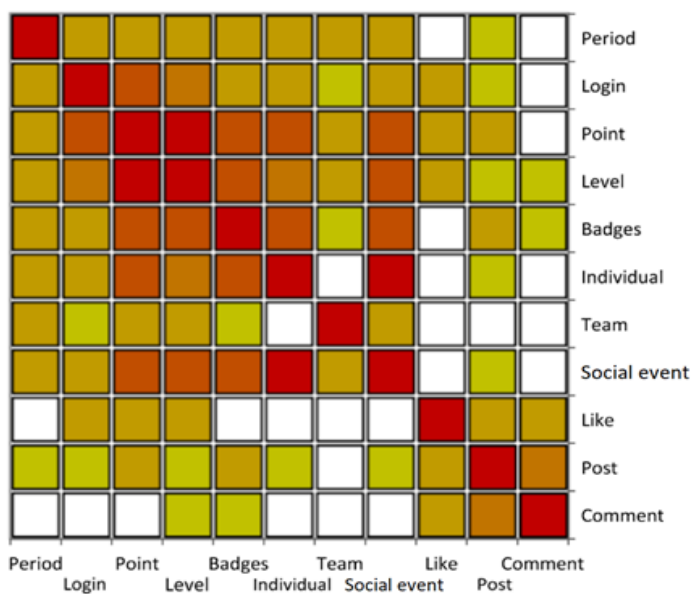

25. ábra: Pearson korrelációs mátrix hőtérképe (Fodor \& Barna, 2020) extra pontszám. Magas pozitív korreláció mutatkozik az elért pontok és a szintek között (0,8, mely evidens abból kifolyólag, hogy a szintlépés egy adott pontszámhatár elérésétől függ), valamint a pontszám és a jelvények között $(0,6)$. Közepes mértékü kapcsolat mutatható ki $(0,5)$ a kiírt bejegyzések és a posztokhoz hozzáfüzött megjegyzések száma között. (Fodor \& Barna, 2020)

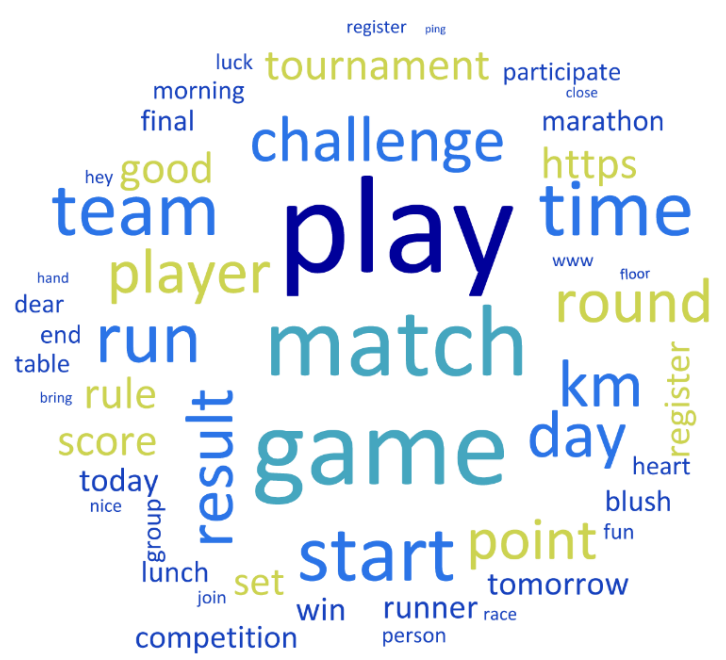

24. ábra: „Elkötelezett” felhasználók megjegyzéseiből készített szófelhő (Fodor \& Barna, 2020)
Az „elkötelezett” felhasználók által írt kommentek tartalmainak vizsgálatát a belölük készített szófelhő segíti (ld. 25. ábra). A szavak között népszerúek voltak a „challenge” (kihívás), „play” (játszani) és „run” (futás) szavak. Ezek a szavak érzékeltethetik a gamifikált szolgáltatás jólléttel kapcsolatos vonulatát. Gyakoriak még a „lunch” (ebéd), „morning” (reggel) és „today” (ma) szavak, melyek alapján feltételezhető, hogy az 
elkötelezettségi szint növelését segítheti, ha munkaidőben is lehetőségük adatik az eseményeken, versenyeken való részvételre. A közösségi élet jelentőségét tükrözik a „team” (csapat) és „group” (csoport) gyakran előforduló szavak. (Fodor \& Barna, 2020)

\subsubsection{Szervező szükségessége}

Az elkötelezettséget befolyásoló személyes tulajdonságok mellett egyéb lehetséges befolyásoló - és a kutatásból kimutatható - faktorok keresését teszi meg a dolgozat ebben az alfejezetben. Először az „elkötelezett” felhasználók mértéke került összevetésre az adott cégmérethez, szervezetenkénti bontásban, melyet a 26. ábra szemléltet. A vizsgálat tárgyát képező szervezetek méretei viszonylag széles skálán mozognak. A közepes méretű csoportok esetében (65-120 fö) nagyobb mértékü átlagos elkötelezettség figyelhető meg, mint a többi cégméret esetében. A felhasználók kommentjeire alkalmazott szövegbányászat rávilágított, hogy az elkötelezettség arányára pozitív hatással bír a „személyes” vagy „szervezői” faktor, pl. egy-két ember a cégben szervezői szerepet tölt be (Fodor \& Barna, 2020). Ez összhangban áll a „társadalmi érvényesítés” teóriájával, mely kifejti, hogy az egyének hajlamosabbak elkötelezett viselkedést tanúsítani olyan dolgok iránt, melyek esetében látják, hogy más is elkötelezett iránta (Cialdini \& Goldstein, 2002).

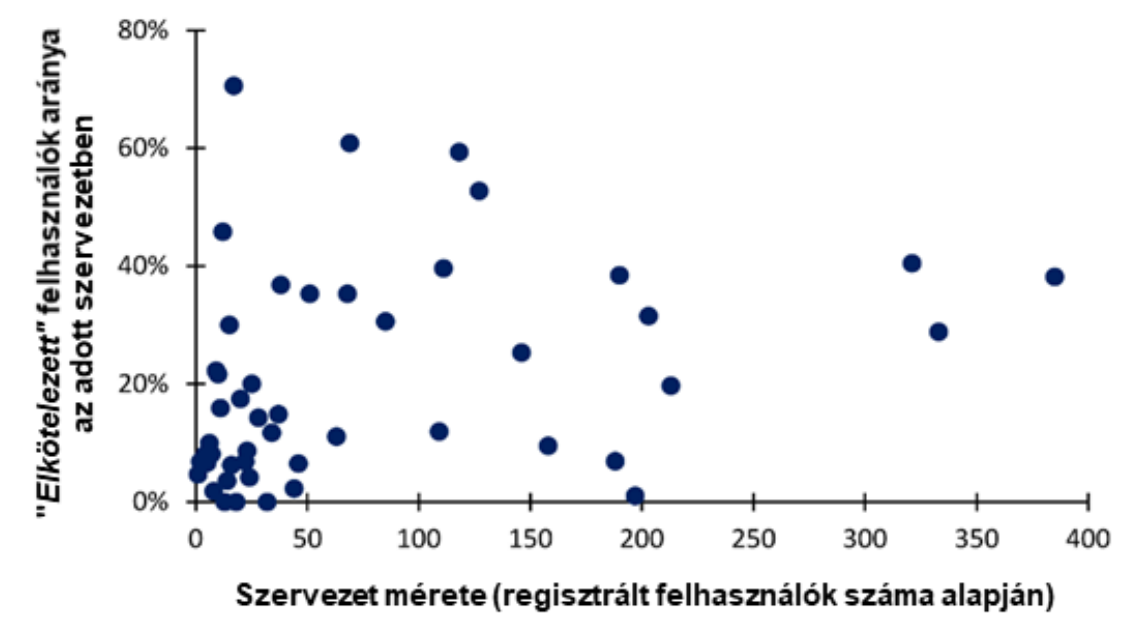

26. ábra: „Elkötelezett” felhasználók aránya a szervezetekben szervezeti méret szerinti bontásban (Fodor \& Barna, 2020)

Érdemes megemlíteni, hogy a szervezők nagy arányban írnak bejegyzéseket és kommenteket, és a klaszteranalízis külön csoportot is kijelölt nekik (ld. 5.4.1. fejezet). 


\subsection{Felhasználói viselkedés becslése}

A szolgáltatásba történő regisztráció során a felhasználók - úgy nevezett - „First Use Tour"-ban (továbbiakban FUT) részesültek, azaz az első használat alkalmával tömören elmagyarázta az oldal, miről is szól a szolgáltatás, megmutatta az alapvető elemeit, valamint - időszakosan - 5 darab kérdést tett fel, melyek esetében 2-2 lehetőség közül tudott választani a frissen csatlakozott felhasználó. A szolgáltatás idejében ez idáig két kérdéscsoporttal operáltak az üzemeltetők, az első 2017. szeptember 15-e és 2018. június 30-a között futott (9,5 hónapon keresztül), míg a második 2018. július 1. és október 31-e között jelent meg (4 hónap). A szolgáltatás az értekezés leadásakor nem alkalmazott FUTkérdéseket az újonnan csatlakozók számára. Jelen fejezet a kérdésekre adott válaszok és a felhasználók viselkedése közötti kapcsolatot keresi, megvizsgálván, milyen elöretekintés adható az adott kérdések megválaszolását követően. Az összevetéshez a felhasználók szintjeit, a különféle egyéni és csapatos versenyeken, szociális eseményeken való részvételüket, szociális funkciók használatát, a gyüjtött jelvényeket és a viselkedéskategóriabesorolásukat (ld. 5.4.2. fejezet) használta fel az elemzés. Midőn a kérdések megválaszolása opcionális volt (azaz dönthetett úgy a felhasználó, hogy kihagyja egyik-másik kérdést), ezért az elemzés során csak azok a felhasználók kerültek bele a vizsgálati populációba, akik mind az 5 kérdésre megadták a válaszukat, valamint az 5.1.2. fejezetben ismertetett feltételeknek megfelelő szervezetek egyikének voltak a tagjai.

Mivel minden kérdés (Q1 ...Q5) esetén 2-2 választási lehetőség (A, B) közül választhatott a felhasználó, ezért technikailag 32 különböző válaszkombináció (C-1 ...C-32) volt lehetséges. A kombináció sorszáma egyben takarja a válaszok sorrendjének bináris átiratából képzett tízes számrendszerbeli számát, ahol $\mathrm{A}=0$ és $\mathrm{B}=1$ (pl. C-17: Q1 $\rightarrow \mathrm{B}, \mathrm{Q} 2 \rightarrow \mathrm{A}$, $\mathrm{Q} 3 \rightarrow \mathrm{A}, \mathrm{Q} 4 \rightarrow \mathrm{A}, \mathrm{Q} 5 \rightarrow \mathrm{B}$, ebből a válaszok kombinációja BAAAB lesz, ami bináris formában átírva 10001-et ad, tízes számrendszerben végül 17-et ad.)

\subsubsection{1. körös FUT-kérdések (I-Q) esetén}

A 2017. szeptember 15-e és 2018. június 30-a között futott első körös kérdések az alábbiak voltak: (A kérdésekhez tartozó opciókat és azok leírásait a 3. mellékletben található 17. táblázat tartalmazza.) 
Q1. Melyik jutalmat választanád inkább?

Q2. Képzeld el, hogy éppen társasjátékozol a barátaiddal. Mi jellemző rád?

Q3. Csapatépítés kapcsán miben lennél benne inkább?

Q4. Hogyan képzelnéd el magad inkább?

Q5. Ha választanod kéne, melyiket preferálnád?

A 9,5 hónap alatt 313 fő töltötte ki mind az 5 kérdést. A kérdésopciók közötti együttmozgást vizsgálván kiderült, hogy a legerősebb korreláció a Q3 és Q5 kérdések között áll fenn, azonban ennek mértéke $(0,15)$ is gyengének, elhanyagolhatónak tekinthető (27. ábra). Q4 és Q5 esetében egészen egyenletesen oszlanak el a válaszok (40-60\%), míg Q1, Q2 és Q3 esetén harmad-kétharmad arányban oszlanak el a választott

\begin{tabular}{|l|r|r|r|r|r|r|r|r|r|r|}
\hline & Q1 A & Q1 B & Q2 A & Q2 B & Q3 A & Q3 B & Q4 A & Q4 B & Q5 A & Q5 B \\
\hline Q1 A & 1,00 & & & & & & & & & \\
\hline Q1 B & $-1,00$ & 1,00 & & & & & & & & \\
\hline Q2 A & $-0,11$ & 0,11 & 1,00 & & & & & & & \\
\hline Q2 B & 0,11 & $-0,11$ & $-1,00$ & 1,00 & & & & & & \\
\hline Q3 A & $-0,05$ & 0,05 & $-0,09$ & 0,09 & 1,00 & & & & & \\
\hline Q3 B & 0,05 & $-0,05$ & 0,09 & $-0,09$ & $-1,00$ & 1,00 & & & & \\
\hline Q4 A & 0,05 & $-0,05$ & $-0,10$ & 0,10 & $-0,02$ & 0,02 & 1,00 & & & \\
\hline Q4 B & $-0,05$ & 0,05 & 0,10 & $-0,10$ & 0,02 & $-0,02$ & $-1,00$ & 1,00 & & \\
\hline Q5 A & $-0,01$ & 0,01 & 0,08 & $-0,08$ & $-0,15$ & 0,15 & 0,00 & 0,00 & 1,00 & \\
\hline Q5 B & 0,01 & $-0,01$ & $-0,08$ & 0,08 & 0,15 & $-0,15$ & 0,00 & 0,00 & $-1,00$ & 1,00 \\
\hline
\end{tabular}

27. ábra: 1. körös FUT-kérdések közti korreláció (Saját ábra) opciók (28. ábra). A kérdések szintekre gyakorolt hatása (3. melléklet 19. táblázat) elhanyagolható, Q3 esetén mutatkozik a legnagyobb különbség, de az A-val válaszolók átlagos szintje is csak 7,3\%-kal haladja meg a B-t választók szintjét. A szociális funkciók közül a tetszésnyilvánítás („like”) tekintetében mind az 5 kérdésnél jelentős különbség tapasztalható. Többször élnek ezzel a funkcióval azok, akik Q1-nél B-t (30\%), Q2-nél Bt (+94\%), Q3-nál A-t (+93\%), Q4-nél A-t (+66\%) vagy Q5-nél A-t (+32\%) választanak. Kommentírást tekintve aktívabbak voltak e téren azok, akik Q2-nél A-t (+31\%), Q3-nál szintén A-t (+82\%), Q4-nél újfent A-t (+47\%) és Q5-nél ugyancsak A-t (+46\%) választottak. Elmondható, hogy az oldal közösségi funkcióit nagyobb valószínűséggel fogja használni az, aki Q3-ra és Q4-re egyaránt az A választ jelöli be. (3. melléklet 19. táblázat) Az elérhető egyéni teljesítménybejelentésen alapuló versenyeken (egyéni „race”) történő részvételnél nem tapasztalható számottevő különbség, míg a mérkőzésalapú megmérettetéseken (egyéni „,versus”) megmutatkozik az eltérés. Q4 esetén míg az A-t válaszolók a meghirdetett egyéni „,versus” események 25\%-án vesznek részt, addig a B-t választók 
a 33\%-ukon, Q1-nél az A-t választók az aktívabbak, negyedével többször jelentkeznek ilyen versenyekre, mint az ellenkező opciót választók.

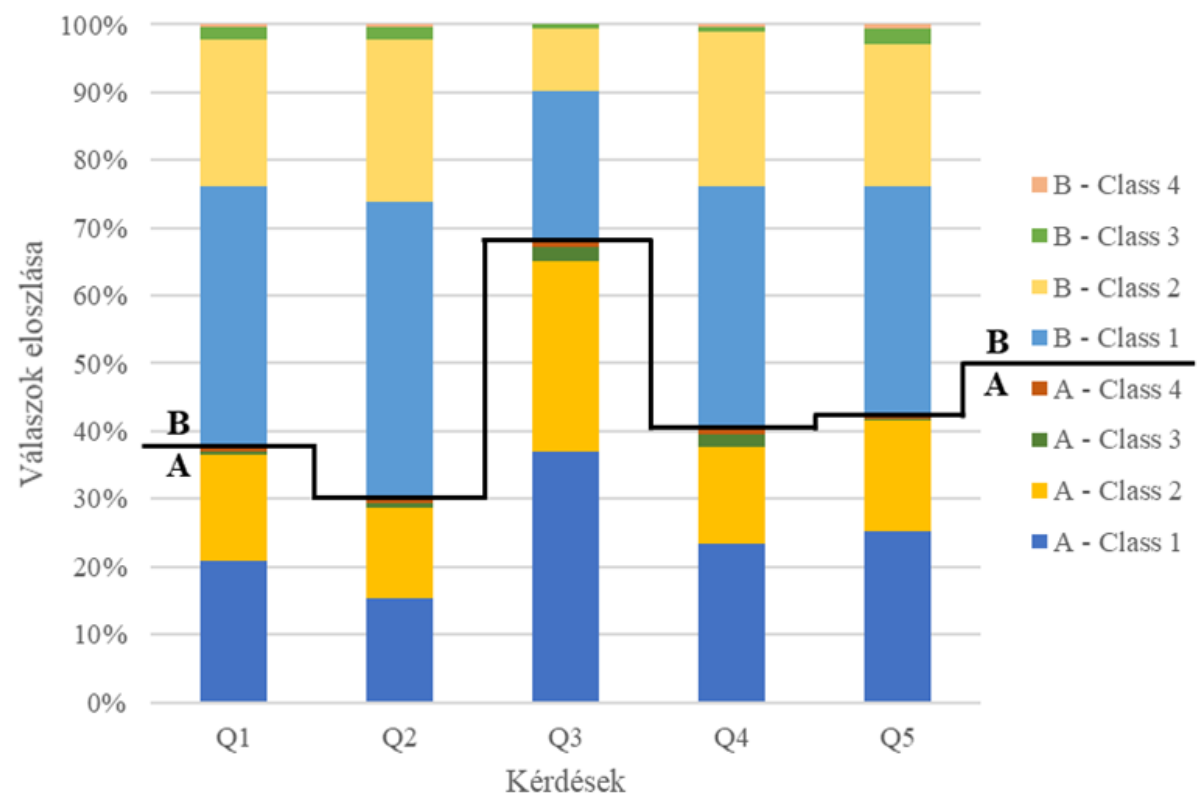

28. ábra: 1. körös FUT-kérdésekre adott válaszok eloszlása viselkedéskategória szerinti bontásban (Saját ábra)

Csapatalapú „versus” eseményeken nagyobb arányban vesznek részt azok, akik Q4-re Bt (+36\%), Q2-re (+26\%) vagy Q3-ra (+39\%) A-t jelöltek, mint ugyanezen kérdések másik válaszát választók. Érdekesség, hogy a csapatos „,race” versenyeken nagyobb különbséget hozó kérdések a „versus” esetén nem tudtak jól szétválasztani. Q1 A-t (+43\%) vagy Q5 A-t (+72\%) választók körében népszerübb a csapatos „,versus” aktivitások. Az egyszerü szociális események tekintetében kevésbé markánsan tudnak a kérdések megkülönböztetni. Q1, Q3 és Q4 tud a két-két tábor között 6-8 százalékpontos különbséget mutatni. (3. melléklet 19. táblázat)

A 313 kitöltő között 185 fő kapott class-1 besorolást (59\%), 117 fö class-2-t (37\%), 8 fö class-3-at (3\%), és 3 fö tartozott a class 4 klaszterbe $(1 \%)^{11}$. A class 4 kategóriával bíró felhasználók alacsony száma miatt nem határozható meg rájuk jellemző tulajdonság. A többi kategória esetében javarészt a válaszok eloszlása leköveti a nagyátlagot, leszámítva class-3-at, aminek tagjai Q4 esetén fordított arányban döntöttek, Q5 kérdésnél pedig a

\footnotetext{
${ }^{11}$ A klaszterekről bővebb ismertetés található az 5.4.2. fejezetben.
} 
többiek egyenletességével szemben 75 százalékpontra növelték a két fél közötti különbséget. (3. melléklet 18. táblázat)

A 32 lehetséges válaszkombináció közül 1 (C-28) különösen népszerü volt, az esetek 11,50\%-át (36 db) foglalja magában, öt C-26 (9\%), C-12 (7\%) és C-27 (5\%) követik. 3$5 \%$ között $8 \mathrm{db}, 1-3 \% 15 \mathrm{db}, 1 \%$ alatt 5 db kombináció teljesített. A továbbiakban csak azokat vizsgáljuk, melyekhez legalább 10 felhasználó tartozik, ez 12 db kombinációt takar. Az aktivitás jellegét nem megkülönböztetve a részvételre a legnagyobb hajlandóságot a C-25, -20, -31 és -11 mutatja, a többi esetében egyenletesen 31-34\% közötti általános részvételi arány szerepel. A tetszésnyilvánítást kiugróan magasan használják a C-27 és C-26 válaszkombinációt benyújtók. Noha a kérdőív értékelésénél nem mutatott egyik kérdés sem számottevő megkülönböztetést az egyéni „race” események kapcsán, a C-25 típusú válaszegyüttes esetén kifejezetten magas, 66\% körüli az indulási hajlandóság. Ugyanezen típusú események csapatos változataira C-11 és C-31 tagjai a legfogékonyabbak (75-79\%), míg a mérkőzésalapú versenyekre egyéniben C-31 és C-20 felhasználói indulnak a legtöbbször (61\% és 49\%), csapatban inkább C-27 válaszolói indulnak neki. A legantiszociálisabbak azok a játékosok, akik a kérdőív kapcsán a C-19 kombinációt választották, ők semmilyen formában nem szeretik a „versus” aktivitásokat, a „race” eseményeken is visszafogottan indulnak, de még a közösségi funkciókat is csak minimális esetben használják, jelvényekből is keveset gyüjtenek. Jelvénygyüjtésben kiemelkedő C11 (akik a csapatalapú „race”-ben is vezetnek), valamint C-25 (akik pedig az egyéni „race” legelhivatottabb résztvevői). (3. melléklet 20. táblázat)

A legpopulárisabb válaszegyüttes (C-28) esetén a class-1 a teljes felhasználói halmazhoz mért részesedési arányához képest is 10 százalékponttal magasabb részvételt tanúsít, mely kombináció egyébként nem tartalmaz kiugró értékeket, meglehetősen átlagosnak nevezhető a területek többségén, a közösségi funkciók esetében még szolidabban is teljesítenek. A class-3 8-fös állománya közül 3 fő C-26-ot választotta, a többiek szétoszlanak a többi kombináció között, ám együttesen sem rendelkeznek határozott jellemzővel. A többi klaszter esetén sem lehet magabiztosan kijelenti, hogy azon kombinációk, melyekben a teljes populáció átlagához képest nagyobb arányban képviseltetnék magukat, előresejtetnék a felhasználó várható viselkedéskategóriáját. (3. melléklet 20. táblázat) 


\subsubsection{2. körös FUT-kérdések (II-Q) esetén}

A „First Use Tour” folyamatában feltett kérdéseket 2018. július 1-jén cserére kerültek, és 4 hónapon keresztül futottak. A 2. körös FUT-kérdőív kérdései az alábbiak voltak: (A kérdésekhez tartozó opciókat és azok leírásait a 4. mellékletben található 21. táblázat tartalmazza.)

Q1. Mennyire ismered jól a kollégáidat?

Q2. Itt a csapatépítés ideje! Milyen hosszú legyen?

Q3. Épp egy unalmas szombat délutánod van. Mit teszel?

Q4. Hogyan viszonyulsz a sportokhoz?

Q5. Egy bonyolult feladvány hever előtted. Mi az első gondolatod?

A 4 hónap alatt 103 olyan fö töltötte ki mind az 5 kérdést, akiknek a szervezete megfelel az 5.1.2. fejezetben ismertetett feltételeknek. A kérdések közötti korrelációt tekintve Q4 és Q5 $(0,23)$, Q2 és Q4 (0,21), valamint a Q2 és Q5 $(0,17)$ között mutatkozik gyenge kapcsolat (29. ábra). Q1 és Q2 közel Q1 A Q1 B Q2 A Q2 B Q3 A Q3 B Q4 A Q4 B Q5 A Q5 B Q1 A 1,00 Q1 B $-1,00 \quad 1,00$ Q2 A $-0,01 \quad 0,01 \quad 1,00$ Q2 B $0,01-0,01-1,00 \quad 1,00$ $\begin{array}{llllll}\text { Q3 A } & 0,00 & 0,00 & 0,06 & -0,06 & 1,00\end{array}$ $\begin{array}{llllllll}\text { Q3 B } & 0,00 & 0,00 & -0,06 & 0,06 & -1,00 & 1,00\end{array}$ $\begin{array}{llllllllllll}\text { Q4 A } & 0,11 & -0,11 & 0,21 & -0,21 & 0,14 & -0,14 & 1,00\end{array}$ Q4 B $-0,11 \quad 0,11 \quad-0,21 \quad 0,21 \quad-0,14 \quad 0,14 \quad-1,00 \quad 1,00$ $\begin{array}{lllllllllllllllll}\text { Q5 A } & -0,12 & 0,12 & 0,17 & -0,17 & -0,07 & 0,07 & 0,23 & -0,23 & 1,00\end{array}$ $\begin{array}{llllllllllllllll}\text { Q5 B } & 0,12 & -0,12 & -0,17 & 0,17 & 0,07 & -0,07 & -0,23 & 0,23 & -1,00 & 1,00\end{array}$

29. ábra: 2. körös FUT-kérdések közti korreláció (Saját ábra)

egyenletesen osztja fel a játékosokat, míg a többinél erőteljes az 1. lehetőségek választása (30. ábra). A válaszlehetőségekhez társított átlagos szintekről elmondható, a kérdések két tábora között általában 0,2-0,5 mértékü különbség áll fenn, ám Q5 sokkal jobban szétválasztja a válaszolókat, hiszen míg az A-t választók esetén egy átlagos felhasználó a 4,67. szintig jut el, addig egy átlagos B-t jelölő csak a 3,14.-ig. A közösségi funkciók használatában 4 kérdés esetén lényeges eltérés mutatkozik. Q1-nél B-t jelölők 3x, Q2 B esetén 3,5x, Q4 A-t választók 4,5x akkora eséllyel élnek a tetszésnyilvánítással, mint az ellentábor, míg Q5 esetén csak az A-t választók használják egyáltalán, akik B-t jelöltek, nem éltek ezzel a funkcióval. Megjegyzésírásnál ugyanezen csoportok számítottak aktívabbnak, noha visszafogottabb mértékben (+ 52-106\%-os aránnyal). Érdekesség viszont - bár nem a két kérdéskör minőségét jellemzi -, hogy II-Q kitöltői messze nem használták olyan mértékben a közösségi funkciókat, mint I-Q válaszolói, hiszen míg az első kérdéskör esetben átlagosan 2-3 tetszésnyilvánítást eszközöltek és 0,5-1 kommentet írtak, addig 
II-Q tagjai 0-1,3 reakciót váltottak ki és 0-0,2 megjegyzést írtak. (4. melléklet 23. táblázat)

Az aktivitásrészvételek alakulását illetően egyedül Q1 nem tud lényeges különbségtétellel szolgálni. Q2-nél látványos, hogy a B-tábor teljesen elzárkózik a csapatalapú „,versus” versenyektől, addig az A fél (az átlaghoz képest) nagyobb hajlandóságot mutat, bár megjegyzendő, hogy eleve nagyon alacsony az ezen típusú versenyeken való részvételi szándék. Q3 A-t jelölői a szociális/közösségi események kedvelői, valamint 1,5x nagyobb arányban vesznek részt a csapatos „race” versenyeken, valamint típusfüggetlenül nézve az összes aktivitás 22\%-ban vesznek részt, szemben a B-t választók 9\%-val. Q4 A és Q5 A szintén az aktívabb réteget képviseli, viszont az alapértéken népszerütlen csapatalapú „versus” események a Q5 B táborában a legnépszerübb. (4. melléklet 23. táblázat)

Érdekesség, hogy míg a bonyolult feladványt bevállalók (Q5 A-t választók) nagyobb kedvet éreznek az egyéni és csapatos „race” versenyek és a közösségi események iránt, valamint 2,5x több jelvényt gyüjtenek, addig a feladvánnyal foglalkozni nem kívánók (B) inkább a „versus” típusú megmérettetések hívei, ám mindemellett teljes érdektelenséget mutatnak a közösségi funkciók használata iránt. Ellenben kirajzolódik, hogy azok a felhasználók, akik már eleve a csapat tagjának érzik magukat (Q1 B), jóval nagyobb mértékben használják a közösségi funkciókat, valamint nagyobb hajlandóságot is mutatnak a különféle aktivitásokban való részvételekre, mint azok, akik még nem ismerik igazán jól a kollégáikat (Q1 A). Ily módon érdemes már az elején nagyobb figyelmet fordítani a kevésbé bevont kollégák beilleszkedtetésére. Azok körében, akik egy „unalmas szombat délutánt” (Q3) inkább szórakozással töltenének (A) mintsem produktivitással (B), látványosan nagyobb részvételt tanúsítanak. (4. melléklet 23. táblázat)

Ezen jellemzők tekintetében Q3, Q4 és Q5 kimondottan erős differenciáló hatással bír, Q1 viszont a legkevésbé járul hozzá a viselkedés megkülönböztetéséhez. Továbbá pozitívum tud lenni, ha egy kérdésnél nagy a két tábor különbsége, ám az 5 kérdésből 3 is 8515\%-os (illetve még nagyobb) válaszadási aránnyal bír, ami egy ilyen rövid kérdőívben túlzó lehet. A kérdések marginális megkülönböztetéseket tudtak eszközölni a jellemzők esetében, ám az egyéni „race” versenyeken való részvétel esetében csak 1 kérdés tudott jelentős különbséget tenni. 
A 103 kérdöív-megválaszoló közül 65-en kaptak class-1 osztályt (63\%), 30-an tartoznak a class-2-be (29\%), 8-an a class-3-ba (8\%), a class 4 pedig nem képviselteti magát $(0 \%)^{12}$. Q1 kérdés esetében a három osztály válaszokközi eloszlása leköveti populációátlagot, Q2 esetén class-3 már erősebb kontrasztot mutat, míg a maradék 3 kérdésben 100\%-osan az A válasz mellett döntöttek. Class-2 tagjai Q5-nél mutatnak még a válaszátlaghoz képest is egyoldalúbb eloszlást. A class-1 klaszter a súlyából adódóan nem mutat eltérést, mivel a populáció java részét ő adja, így az ő válasz-megoszlását tükrözi le elsősorban a főátlag. (4. melléklet 22. táblázat)

A 32 lehetséges válaszkombináció közül C-17 vált a legnépszerübbé, az esetek negyedében választották a BAAAB kombinációt, a második legtöbbször választott eset a C-1 (19\%), a 3. a C-25 lett (15\%). Rajtuk kívül még 1 esetben érkezett legalább 10 kitöltés (C-9). 11 esetében nem érkezett kitöltés, további 14 esetében teljesen figyelmen kívül hagyták a közösségi funkciókat (22fö), 17 kombináció tagjai nem játszottak egy „,versus” versenyt sem (40 fö). A legalább 10 fővel rendelkező csoportok közül C-17 tagjai között fordult elő (de ott is visszafogottan), hogy csapatalapú ,versus” bajnokságon vettek részt, a többi esetében nem jelentkeztek ilyesmire, C-9 a szóban forgó típus egyéni versenyeit is kihagyta, ám a másik 3 csoport pedig minden alkalmat kihasznált a részvételre. „Race” jellegü versenyeken közel egyenlő arányban vett részt a 4 csoport (egyéni 33-42\%, csapatos 73-76\%), kivéve újfent C-9, akik a csapatalapú megmérettetések negyedén vett csak részt. Közösségi eseményeken leginkább C-25 és C-9 vettek részt (4. melléklet 24. táblázat). C-25 más tekintetben is pozitív példa, ugyanis a közösségi funkciókat a leggyakrabban használta (átlagosan 3 tetszésnyilvánítás/fö értéket ért el, míg a másik 3 kombináció 0,2-0,8 cselekvést tud felmutatni), valamint több mint $2 \mathrm{x}$ annyi jelvényt gyüjtöttek, mint a maradék 3 nagy csoport. (4. melléklet 24. táblázat)

A négy legnépesebb részpopuláció magában foglalja a class-1 tagjainak 66\%-át, a class2 73\%-át, s a class-3 tagjainak a 75\%-át. A 3. legnagyobb csoport (C-25) szívja fel a class-3 (a Teljesitök) több mint harmadát, mely csoportra jellemző a kiugróan magas gyüjtött jelvények száma. A magas játékosszintet elérő csoportokba (8 db kombináció, min. érték: 5,00) a class-1 tagjainak alig több, mint negyede tartozik (28\%), a class-2

\footnotetext{
${ }^{12}$ A klaszterekről bővebb ismertetés található az 5.4.2. fejezetben.
} 
esetén már majdnem minden második felhasználó (43\%), miközben class-3 válaszolóinak 75\%-a tartozik közéjük. (4. melléklet 24. táblázat)

\subsubsection{FUT-kérdések összevetése}

Az 1. körös kérdések (I-Q1 ...I-Q5) 9,5 hónapig futottak, ami alatt 313 kitöltés érkezett, míg a 2. körös kérdések (II-Q1...II-Q5) 4 hónap alatt 103 fötől gyüjtöttek be választ. Korreláció szempontjából mindkét csoport kérdései megfelelőnek bizonyultak, II-Q esetében előfordult gyenge együttmozgás. I-Q kérdései zöme megosztó volt, míg II-Q esetén több kérdés is viszonylag egyhangú választ adott.

I-Q a kérdéseivel nem tudta úgy felosztani a kitöltőket, hogy játékosszintjeikben különbség adódjon, míg II-Q az 5. kérdésével ezt el tudta érni. A közösségi funkciók használatát tekintve I-Q a 3. kérdésével tudta a legjobban szétválasztani a tetszésnyilvánítási és kommentírási hajlandóságot, noha II-Q radikálisabb különbségeket tudott eszközölni, kérdéseik közül is a legjelentősebben Q4 és Q5 volt erre képes. Q5 szabályosan leválasztotta az ezen funkciókat nem használókat. Jelvénygyüjtés tekintetében is II-Q kérdései (szintén Q4 és Q5) tudnak jobb felosztást biztosítani. (3. melléklet 19. táblázat, 4. melléklet 23. táblázat)

A kitöltő felhasználók aktivitásrészvételeit tekintve I-Q kérdései szolid szétválasztást tudtak elérni. A „versus” események kapcsán Q4 tudott 30-39\%-os többletet felmutatni az adott opciópárhoz képest egyéni és csapatos kategóriában, míg II-Q 3. és 4. kérdése teljes szétválasztást eredményezett. „Race” típusú versenyek részvételének megkülönböztetésében mindkét kérdéssornak nehézségei támadtak, az egyénieknél egyedül II-Q5 tudott jelentősebb különbséget felmutatni. A csapatalapúak körében I-Q1, I-Q5, II-Q3 és II-Q5 tud különbséget tenni a két-két tábor között 17 és 26 százalékpontnyi mértékekben. Közösségi események tekintetében II-Q3, 4 és 5 tudott komolyabb megkülönböztetéssel élni. (3. melléklet 19. táblázat, 4. melléklet 23. táblázat)

A válaszokból álló kombinációk (I-C-x, II-C-y) többsége mindkét kérdéscsoport esetén kevéssé megbízható információt tudott nyújtani. Az első kérdéskörhöz tartozó I-C-26 és -27 kombinációk tagjai használták a legaktívabban közösségi funkciókat, I-C-30 felhasználói pedig átlagon felül teljesítettek a különféle részvételeken, az egyéni „,versus” aktivitásokban a legnagyobb részvételi arányt nyújtották. Míg maguk a kérdések nem tudták 
megbecsülni az egyéni „race” versenyeken való szereplést, addig I-C-25 kifejezetten erős szereplést sugall az ilyesfajta versenyekben (amely csoport egyben a legmagasabb általános részvételi kedvvel is rendelkezik), I-C-27 pedig gyenge hajlandóságot mutat. A viselkedéskategóriákat tekintve leszürhetö, hogy a class-3 klaszterbe tartozó Teljesitók a IQ3 kérdésnél A-t választják, valamint kitartóbb felhasználóknak bizonyulnak, ugyanis átlagos szintjük meghaladja a többi klaszterre jellemző értéket. (3. melléklet 20. táblázat)

II-Q kérdései kapcsán jobban koncentrálódtak a beérkezett válaszok, bár a kitöltők száma harmada az I-Q csoporténak. Az II-C kombinációk közül 11 esetében nem érkezett kitöltés, 14 kombináció tagjai figyelmen kívül hagyták a közösségi funkciókat. Ha a felhasználó kitöltése egyezik a II-C-17 vagy -25 válaszaival, akkor várhatóan magas hajlandóság várható tőle a különféle aktivitások kapcsán. Azok, akik végül a class-3 jegyeit mutatták, többnyire olyan kombinációt választottak, mely a jelvénygyüjtésben átlagon felüli értéket hoztak, a legnagyobb csoportosulásuk I-C-25-ben történt meg, mely kiugró mértékű jelvényszámmal rendelkezik (megfelelvén a Teljesitők elképzeléseinek). (4. melléklet 24. táblázat)

Összességét tekintve a szolgáltató részéről pozitív kimenetelü döntés volt, miszerint lecserélték az 1. körös kérdéseket a 2. kérdéscsoportra. II-Q kérdései eredményesebb szétválasztást tudtak eredményezni, ám érdemes tovább finomítani a kérdéshalmazt. Az első körből I-Q1 és I-Q3 tekinthető hasznosnak, az előbbi az egyéni „versus” és a csapatos „race” megkülönböztetése miatt, az utóbbi a közösségi funkciók terén és a jelvénygyüjtés kapcsán. Mivel II-Q között szerepel több olyan kérdés, mely hatásosabban tudta megkülönböztetni az online közösségi élet iránt fogékony, valamint a különféle versenyeken részt venni kívánó felhasználókat, ezért nem tartom javasoltnak megtartani az összeset közülük. A II-Q halmazból a 4. és 5. kérdés megtartása javasolt, mert ezek segítenek megkülönböztetni a közösségi funkciók iránt fogékonyakat, a jelvénygyüjtéshez való különböző hozzáállásúakat, az egyéni és csapatalapú „,versus” és „,race”, valamint a közösségi eseményeken részt venni vagy nem venni kívánókat. Alaposabb, megbízhatóbb és többletinformációk kinyeréséhez még további, mélyebb statisztikai elemzések szükségesek, valamint az I-Q és II-Q kérdőívek vegyítéséből származó kombinációk vizsgálatát is érdemes a jövőben megtenni. 
A következő alfejezetek a visszajelzési kérdésekre adott válaszokat elemzi általánosabb megközelítésben, megvizsgálván, milyen változásokat tapasztaltak a felhasználók a munkahelyükkel, munkatársaikkal és sportolási szokásaikkal kapcsolatban a szolgáltatás használata során.

\subsection{Munkahelyi légkör változásának elemzése}

A „Hogyan változott a szervezeténél a légkör a szolgáltatás bevezetése óta/az elmúlt 30 napban?" kérdésekre adott visszajelzések alapján (1223 db) kiolvasható (30. ábra), hogy a válaszadók többsége pozitív légköri változásokat tapasztalt a munkahelyén $(61,41 \%)$, negatív irányba történő változás érzetéről 2,62\% számolt be, míg a válaszok közel harmada $(35,98 \%)$ nem tapasztalt változást.

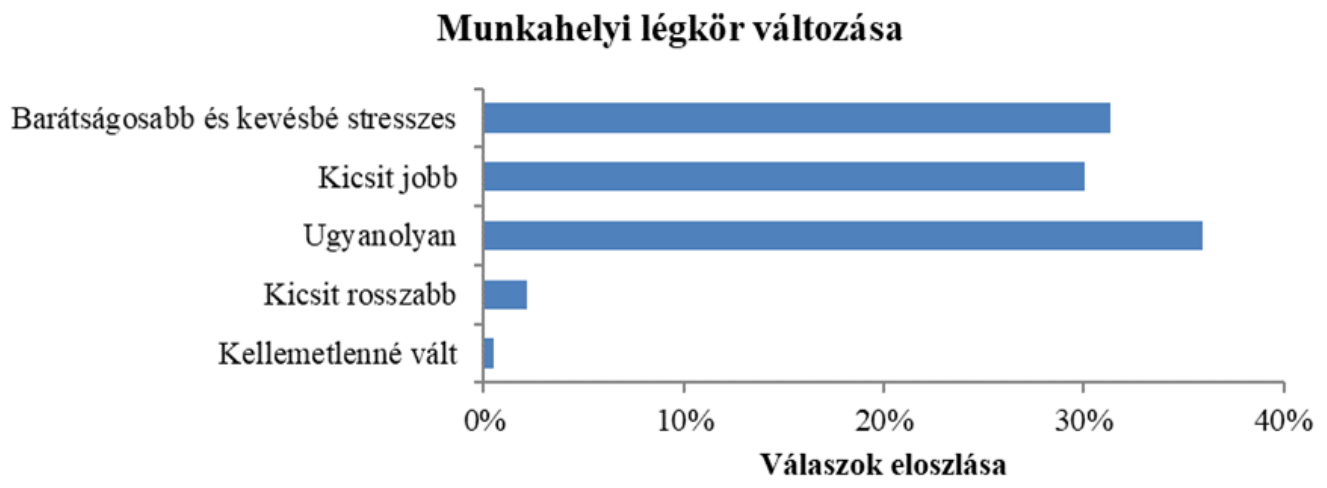

30. ábra: Munkahelyi légkör változása a szolgáltatás bevezetése után (Saját ábra) 
Az összesített adatok mellett azok időbeli változása a szolgáltatás hosszabb távú használhatóságát jellemzi (Barna \& Fodor, 2018b). A 32. ábra a játékosok visszajelzéseinek darabszámát, átlagos értékelésüket és szórásukat takarja, melyek a fiókkészítésük (vagy 2017. február 1. óta, a visszajelzési rendszer élesítését követően, ha a szervezet már előtte is használta a szolgáltatást) és a visszajelzés leadott ideje között eltelt idő alapján 4-hetes időszakokba rendeződtek. Megfigyelhető, hogy a 2. hónapot követően csökkenő tendenciára állt a visszajelzése száma, ám folyamatosan pozitív változást igazoló átlagos értékelést nyújtanak az időszakok. A 49-52. heti időszakoktól kezdve már alacsony számú (<20 db) válaszadásokból gazdálkodik az ábra. Az alacsony szám ellenére megjegyzendő, hogy a rendkívül hosszú fiók-életszakaszú felhasználók (akik már legalább 121 hete regisztráltak) a korábbi blokkok mérsékelt pozitív értékelésekhez képest határozottan pozitív változásról számolnak be. Ez alapján elmondható, hogy a szolgáltatásban résztvevő munkavállalók szemében saját bevallásuk szerint javult a munkahelyük légköre.

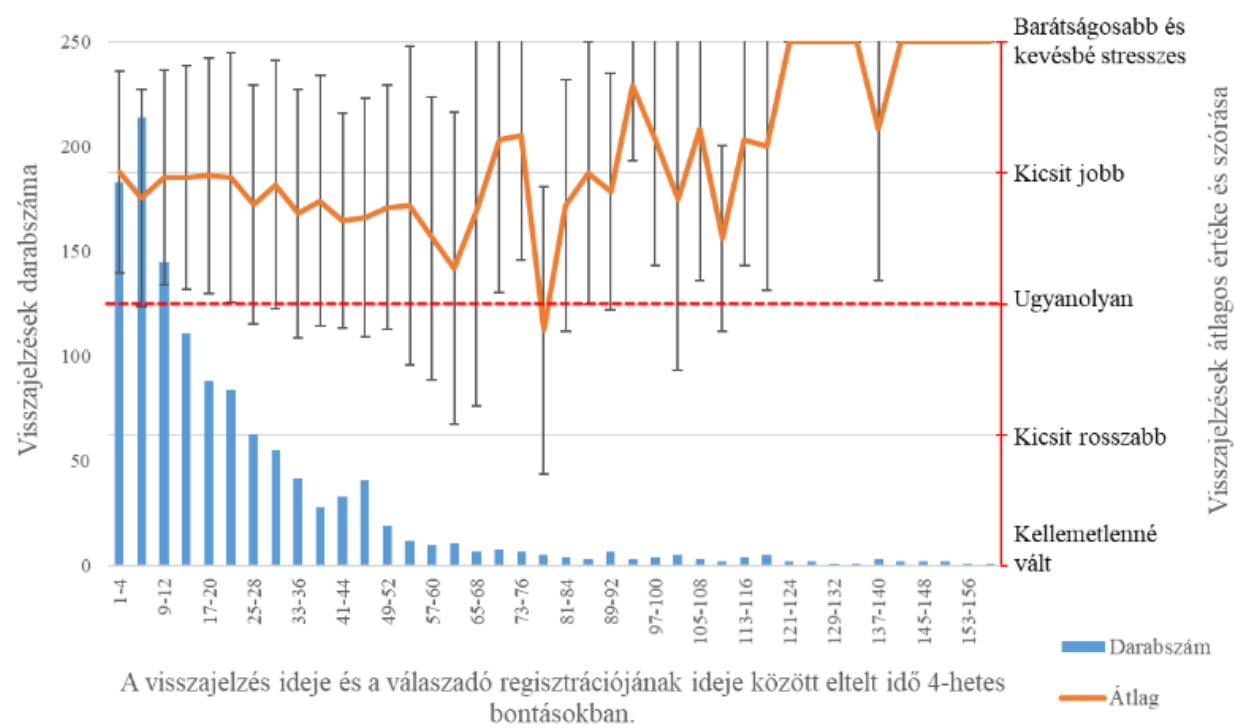

31. ábra: A munkahelyi légkör megítélésének változása 4-hetes időszakblokkokra bontva (Saját ábra)

\subsection{Kapcsolati háló méretének és minőségének változása}

\subsubsection{Visszajelzések alapján}

A kapcsolati háló kiterjedésére a „Hány egyáltalán nem vagy kevésbé ismert emberrel ismerkedett meg az alkalmazáson keresztül az elmúlt 30 napban?" kérdésre adott visszajelzések adnak becslést (Barna \& Fodor, 2018b). Ezek alapján (32. ábra $\boldsymbol{A}$ panel) a 
válaszadók 83,90\%-a ismerkedett meg legalább 1 emberrel, közel harmaduk $(31,22 \%)$ pedig legalább hat (részben vagy teljesen) ismeretlen emberrel teremtett kapcsolatot.

A kialakított kapcsolatok minőségére vonatkozó kérdésre („Jobb-e a kapcsolata azokkal az emberekkel, akikkel már játszott együtt?’) a válaszok több mint négyötöde pozitív eredményről számolt be (32. ábra $\boldsymbol{B}$ panel): a visszajelzők 53,97\% úgy érzi, kicsivel jobb lett a kapcsolata, 26,98\%-a az „Igen, sokkal jobb!” válasszal élt, 17,99\% változatlannak érzi, míg a kétfajta negatív változásról összesen 2 esetben érkezett jelentés $(1,06 \%)$.
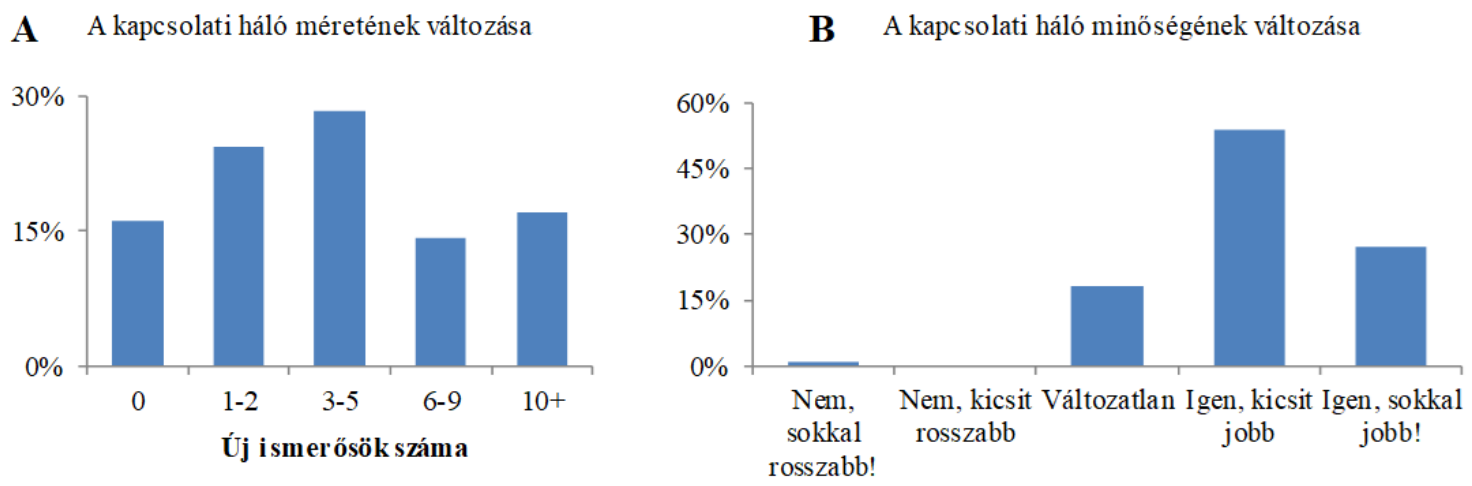

32. ábra: A munkahely légkörének és a kapcsolati háló méretének változása a vizsgált időszakban (Barna \& Fodor, 2018b)

\subsubsection{Adott szervezet alapján}

A szervezeten belüli kapcsolati háló fejlődésének vizsgálatát célzó kutatás számára egy adott cég életében végbemenő munkahelyi kapcsolatmódosulások adták az alapot. A vizsgált szervezet 118 regisztrált felhasználóval rendelkezett, melyek közül egyik sem kategorizálható be „újfelhasználó”-ként, azaz mindegyik felhasználó legalább 100 napja csatlakozott a szolgáltatáshoz. 48 fö számított „,nem elkötelezett” felhasználónak, míg 70 fő „elkötelezett”-nek tekinthető, ezáltal a cég elköteleződési rátája 59\%. (Fodor \& Barna, 2020) (A besorolás alapjai megtalálhatóak az 5.4.1. fejezetben).

Az „elkötelezett” felhasználók a munkahelyi kapcsolatok növekedésére rákérdező visszajelzési kérdésre (Rel-1, ld. 8. táblázat) adott válaszaik alapján kiderül, hogy egyenként többnyire 6-9 új egyáltalán nem vagy kevéssé ismert munkavállalóval teremtettek kapcsolatot az elmúlt hónapban (Fodor \& Barna, 2020). Ez az érték azonban idővel csökkenésnek indul, mely magyarázható az új kapcsolat kialakításának fogyatkozó lehetőségeivel, azaz egyre kevesebb olyan ember marad, akivel még nem találkoztak. 
A vizsgálat következő lépése arra keresett választ, hogy a vállalaton belül a felhasználók mennyire vegyülnek a különféle események során, mennyire ragaszkodnak ugyanazokhoz a társakhoz a részvételkor. A vállalat összesen 35 eseményt és versenyt szervezett, melyből 24-et ugyanaz a szervező menedzselt, egy másik szervező hétszer vállalta magára a feladatot, a maradék 4-et pedig 4 különböző felhasználó igazgatta (Fodor \& Barna, 2020). A 33. ábra szemlélteti a sorrendben indított események és versenyek résztvevőszámát, külön jellel azonosítva az egyes szervezőket.

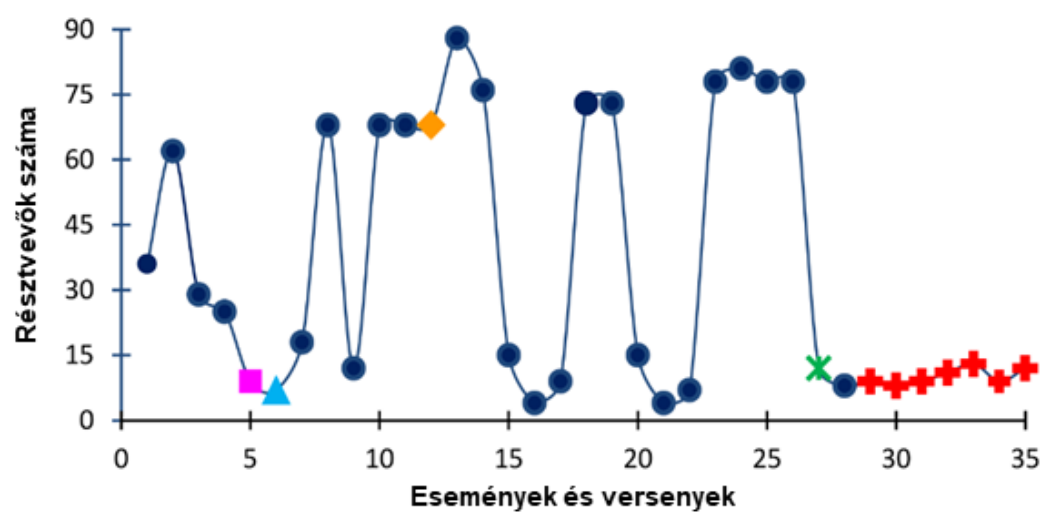

33. ábra: Sorrendben indított események és versenyek résztvevőszáma, szervezőnkénti jelöléssel (Fodor \& Barna, 2020)

13 esemény kapcsán több, mint 50 fő vett részt rajtuk. Mivel összesen 118 regisztrált fővel rendelkezik a vállalat, így több felhasználóra is igaz, hogy nem csak egy eseményen vett részt (Fodor \& Barna, 2020). Azonban kérdéses, hogy egy szervező mennyire tudta megfogni a potenciális résztvevőket, valamint a felhasználók mennyire szánták el magukat a részvételre.
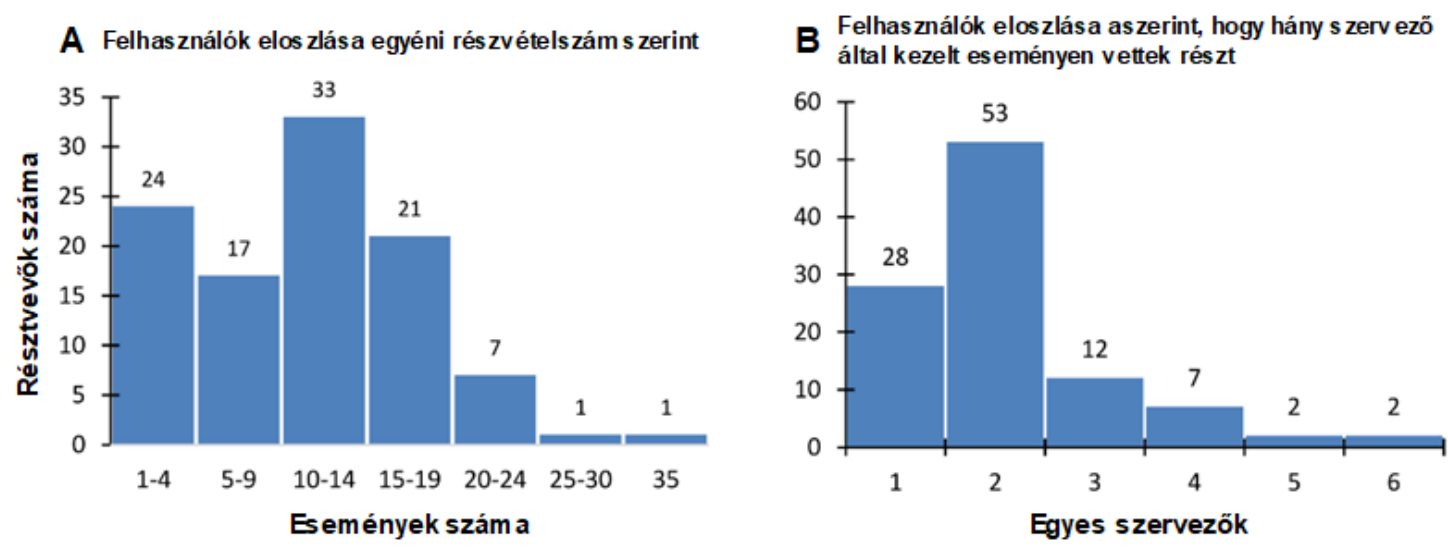

34. ábra: Felhasználók eloszlása részvétel szerint (Fodor \& Barna, 2020) 
A 34. ábra $\boldsymbol{A}$ paneljéről kiolvasható, hogy a regisztrált felhasználók többsége legalább 10 eseményen/versenyen vett részt, 9-en pedig 20 vagy annál is több lehetőséget ragadtak meg, és van, aki mindegyiken részt vett. A $\boldsymbol{B}$ panel azt mutatja meg, hogy a felhasználók mennyire választottak kizárólagosan a szervezők közül, mikor a részvétel felől döntöttek. Az ábra alapján a potenciális résztvevők közel egynegyede választott olyan eseményeket, melyeket egy adott szervező bonyolított le, míg 51\%-uk két szervező által kezelt megmozdulásokon vett részt. Akadt két fö, akik voltak annyira elszántak, hogy az összes szervező repertoárjából válasszanak legalább egy eseményt. (Fodor \& Barna, 2020)

A szociális háló feltérképezése hálózatelemzési technika segítségével került megvizsgálásra. Az elkészült hálózattérkép (ld. lentebb 35. ábra) pontjai a regisztrált felhasználókat szimbolizálják, a pontokat összekötő szakaszok a két felhasználó legalább egyszeri közös részvételüket jelöli. A hálózati struktúra legegyszerübb mérőeszköze, mellyel a hálózati kapcsolat felmérhető, a hálózati sürüség. A sürüség a kötelékek tényleges száma és a kötelékek lehetséges mértékének hányadosa (Scarbrough, et al., 2014). A vizsgálat eredményeként egy 0,04-os sürüségi, gyengén kapcsolódó, irányítatlan gráf keletkezett. Noha a sűrüség gyakran használt mérőszáma a kapcsolódások vizsgálatának, alacsony általános sürüség mellett is lehetséges, hogy 2 vagy több alcsoport hálójára magas sürüség jellemző. A széttöredezettség ellenőrzéseként kiszámítottuk a hálózat geodéziai távolságát. A geodéziai távolság az emberek közötti összeköttetések átlagos számát takarja a hálózatban (Scarbrough, et al., 2014). A pontok átlagos fokmértéke 4, az átlagos geodéziai távolság 2,25, strukturális lyukak pedig nem találhatóak. A gráfon (35. ábra) kitünik, hogy a kapcsolatok többsége erős (összekötő szakaszuk vastag) és lokális, de található néhány távoli kapcsolat is (Fodor \& Barna, 2020). Eme struktúra a „kisvilág” tulajdonságú hálók jellegzetességeit tudja magáénak, ahol kis csoportokon belül szorosan kapcsolódnak egymáshoz az egyének, és a csoportok néhány szálon egymással is kapcsolatban állnak. Több tanulmány is rávilágított (Uzzi \& Spiro, 2005) (Giuffre, 2015), hogy ha egy hálózat a „kisvilág” jellegű háló tulajdonságaival rendelkezik, a hálózat tagjai szoros kapcsolatban állnak egymással, és vélhetőleg a kapcsolatuk már korábbi kollaborációt is megélt már. Ez a struktúrafelépítés magyarázhatja a vállalat magas elkötelezettségi rátáját (Fodor \& Barna, 2020). 


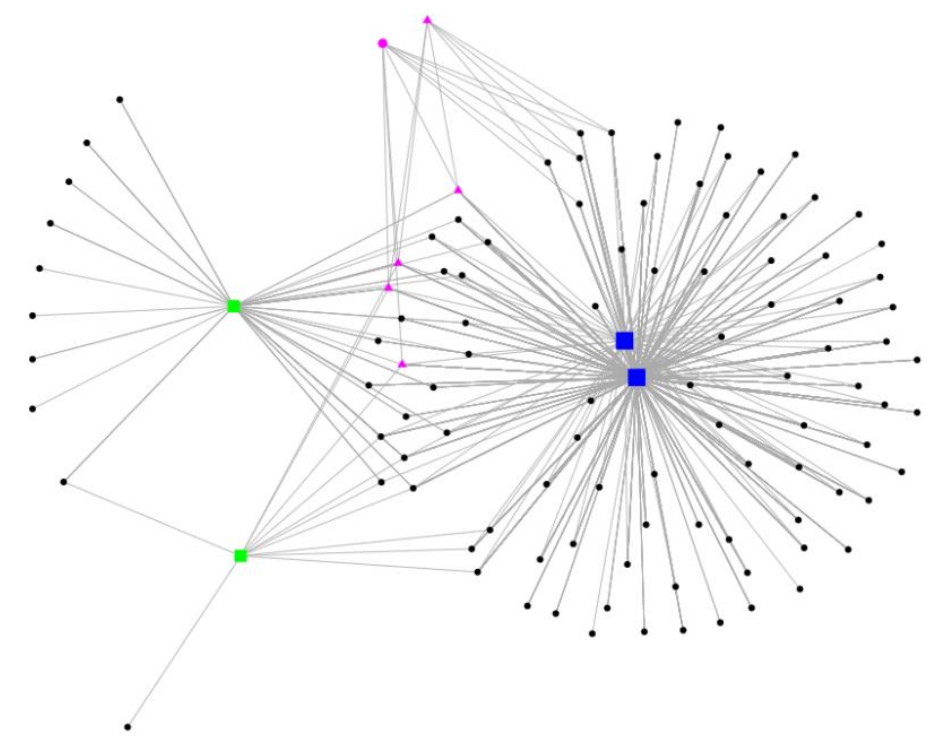

35. ábra: Eseményrészvételen alapuló kapcsolati háló (Fodor \& Barna, 2020)

Ezek az eredmények alátámasztják azt a korábbi felvetést, miszerint az általános elköteleződési szintre jótékony hatással bír, ha a szervezetben léteznek olyan munkavállalók, akik magukra vállalván a szervezői szerepet menedzselik a cég különféle eseményeit. Kisebb csoportok, „,klikkek” alakulhatnak ki, akik leginkább egymás társaságában kívánnak részt venni a rendezvényeken. Ily módon javasolt eljárásnak tekinthető, ha a cég (valamint a szolgáltatásüzemeltető) különös figyelmet fordít a cég véleményvezéreire, ha meggyőzésükkel őket veszik célba, mert ők könnyebben sarkallhatják kívánatos cselekvésre a többi munkavállalót, bár ez a koncepció további vizsgálatot követel még. (Fodor \& Barna, 2020)

A továbbiakban az általános, teljes vizsgálati populációra jellemző, a visszajelzési kérdésekből levonható sportolási szokások és hangulat változását vizsgálja az értekezés.

\subsection{Sportolási szokások változása}

A válaszadók sportolási szokásai kapcsán kimondottan pozitív változás olvasható ki az összegyült visszajelzésekből (36. ábra $\boldsymbol{A}$ panel). Arra a kérdésre, miszerint érzése szerint többet sportol-e a szolgáltatás használata óta, a beérkezett 2308 db visszajelzésből 35,40\% az „Igen, sokkal többet!” adta válaszul, további 26,99\% az „Igen, kicsit többet” válaszlehetőséggel élt, míg 36,05\% esetében úgy érezték, nem változott a sportolási 
szokásuk. A visszajelzések alapján a felhasználók 0,87\%-a kicsivel, 0,69\% esetében számottevően kevesebbet sportolnak, mióta bevezették a szolgáltatást.

A Sportolási hajlandóság változása a szolgáltatás bevezetése óta

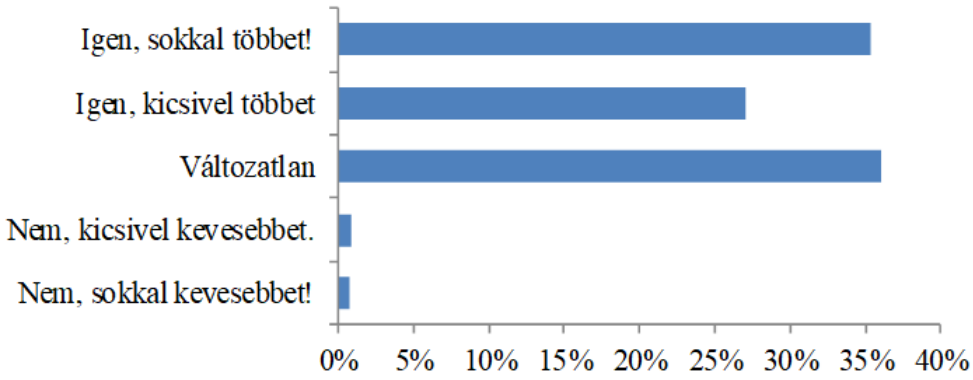

B Sportolási hajlandóság változása azok rögzíthetősége miatt

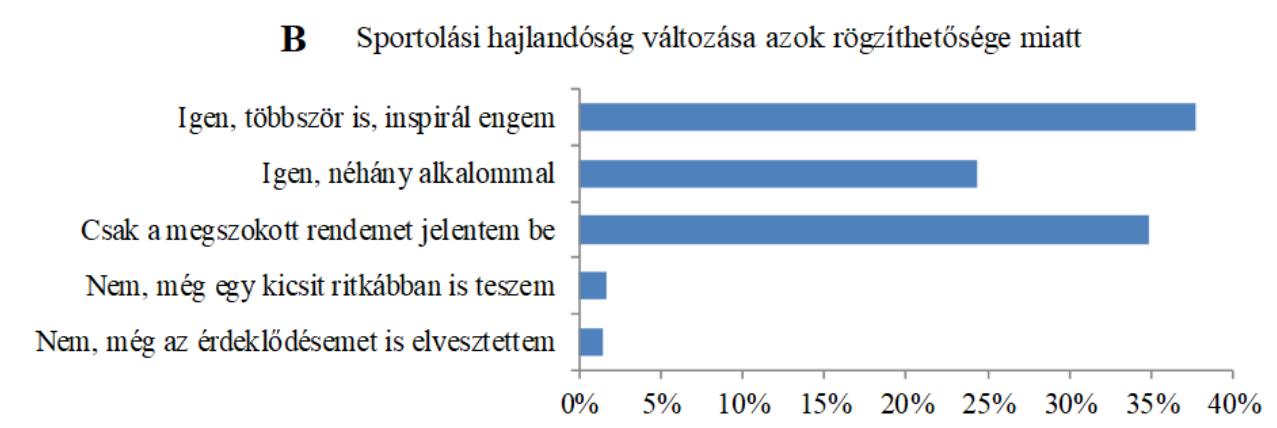

36. ábra: A sportolási szokások változása a vizsgált időszakban (Saját ábra)

A használatból eredő sportolási gyakoriság változásáról szóló visszajelzések időbeliségét vizsgálva (2. melléklet) kitünik, hogy az általános pozitív hatás hosszútávon is fennmarad. A sportolási hajlandóság változására irányuló vizsgálat másik megközelítése a szolgáltatásban történő eredményfelvitel motiválóerejét vette szemügyre az „Elöfordult-e már, hogy [adott sportból] többet üzött csak azért, hogy a szolgáltatásban rögzítse az eredményét?" kérdéssel (36. ábra $\boldsymbol{B}$ panel). Ezt a kérdést elsősorban a teljesítménymérésen alapuló sportok (úgymint futás, biciklizés) esetén kapták a felhasználók (Barna \& Fodor, 2018b). A válaszadók 34,84\%-a jelezte, hogy a megszokott rutinját vezeti a szolgáltatásban, azonban a felhasználók 24,32\%-a úgy vallott, hogy már néhányszor előfordult, míg $37,70 \%$ az erős „Igen, többször is, inspirál engem” válasszal élt, ezek mellett viszont csak 3,14\% jelzett vissza részleges vagy teljes érdeklődésvesztést. Ezek alapján kijelenthető, hogy a vizsgált online szolgáltatás - mint külső motivációs eszköz - közremüködésével sikerült belső késztetést ébreszteni a felhasználók egy részében, motiválván őket a többszöri sportolásjellegü cselekedetre. 


\subsection{Hangulat változása}

A lejátszott mérkőzések után (pontosabban, amihez eredményt jelentettek be) a játékosok hangulata is mérésre kerül a „Mennyire volt számodra szórakoztató?” kérdés feltevésével (Barna \& Fodor, 2018b). A válaszok a vizsgált időszakban egy 5-ös fokozatú skálán mozogtak, melyben a legkisebb érték (1) a „Nem tetszett.”, míg a legnagyobb érték (5) a „Fantasztikus volt!” véleményt takarta. A beérkezett vélemények 79,97\%-a legpozitívabb értékelést választotta, további $13,24 \%$ a szolidabb, ám továbbra is pozitív értékelést adta, míg 1,19\% számára közömbös, 2,38\% számára kissé negatív élmény nyújtott, és 3,23\% a válaszoknak számolt be kifejezetten negatív érzésröl.

A válaszadók hangulata összevetésre került a játékosok szintjével, hogy kiderüljön, tapasztalható-e kölcsönös együttmozgás a két tulajdonság között (Barna \& Fodor, 2018b). A kérdésre adott játékosonkénti átlagos értékelés és a játékosok pontszintje között 0,05os korreláció mutatkozik, mely nem ad alapot fennálló kapcsolatra. Ebből az a következtetés vonható le, hogy az elégedettséget bizonygató válaszokat adók eloszlása független a tapasztalattól, azaz ugyanúgy élvezte egy kezdő felhasználó a játékot, mint egy tapasztaltabb (Barna \& Fodor, 2018b).

\subsection{Kutatás limitációi}

A kutatások eredményét némileg korlátozza a tény, hogy a vizsgált szolgáltatás által gyüjtött, visszajelzési kérdésekre adott válaszok önbevallás-alapúak. A visszajelzéseket javarészt aktív résztvevők szolgáltatják, akik általában rendelkeznek részvételi indíttatással. Mivel a kérdésekre történő válaszadás minden esetben opcionális, így a „nem elkötelezett” felhasználók vizsgálatát nem teszi lehetővé. (Fodor \& Barna, 2020)

A visszajelzési kérdések megfogalmazása, valamint a lehetséges válaszok szövegezése nem minden esetben felel meg a pártatlanság, befolyásmentesség elvének, ám ezek a kutatások során adottak voltak, módosításukra, újrafogalmazásukra nem volt lehetőség. 


\section{OKTATÁSI KÖZEGBE ÉPÍTETT GAMIFIKÁCIÓ HATÁSA}

\subsection{E-learning rendszerek}

\subsubsection{Budapesti Corvinus Egyetem által használt elektronikus ok- tatási rendszer}

Oktatáscélú e-learning rendszer használata mára bevett szokássá vált az egyetemi kurzusok körében. Egy jól felépített e-learning rendszer nemcsak tárolóhelyként támogathatja a kurzust, hanem elősegítheti a hallgatókat az adott tananyag elsajátításában is (Barna \& Fodor, 2019a). Általános stratégia egy kurzus gamifikálására, hogy először egy e-learning környezetet állítanak fel, majd ebbe implementálnak gamifikációs elemeket (Jurgelaitis, et al., 2018). Pastor-Pina és szerzőtársai rávilágítottak, hogy egy oktató kialakíthat egy tanulást támogató környezetet, de a tanulónak is aktív szerepe van a siker eléréséhez. A hallgatói motiváció és elhatározás kulcsfaktoroknak számítanak a tanulási folyamatban. (Pastor-Pina, et al., 2015)

A Moodle (Modular Object-Oriented Dynamic Learning Environment) e-learning környezet széleskörben kínál lehetőségeket egy hallgatóközpontú, megfelelően menedzselhető kurzus felületének kialakításához (Barna \& Fodor, 2019a). A Moodle egy nyílt forráskódú, PHP programnyelvben írt szoftver, mely szabadon és ingyenesen telepíthető, módosítható és személyre szabható. A Budapesti Corvinus Egyetem több e-learning alapú oktatási rendszert használ, amik közül a Moodle rendelkezik a legtöbb funkcióval, és ez a legelterjedtebb az egyetemen. (Barna, 2016)

Az eszköz adott, habár a hallgatók motivációja gyakran nem kielégítő. Noha a kurzus sikeressége nagyban függ az oktatott anyagtól, gamifikációs elvek követésével növelhető a hallgatók motivációs szintje (Barna \& Fodor, 2019a).

A Moodle tájékoztató anyaga alapján többek között az alábbi aktivitásjellegü funkciók érhetőek el (Moodle, 2015): 
- lecke

- szójegyzék

- adatbázis

- wiki
- beadandó

- választás

- kérdőív

- kvíz
- fórum

- chat

- részvétel

- felmérés

\subsubsection{Moodle által nyújtott gamifikációs lehetőségek}

A vizsgált e-learning rendszerben számos plugin is elérhető. A Moodle bizonyos alapelemei hasznosnak bizonyulnak a gamifikáció szempontjából is, úgymint dokumentumok, oldalak, oldalrészek, feladatok elérésének korlátozása, szabályokhoz kötése. A feladatok teljesítésének nyomon követésével, valamint a tevékenységek elérhetőségének korlátozásával külön felhasználói szintek határozhatóak meg, egy áttekintő térkép készíthető a kurzus felderíthető részeiröl, vagy éppen rejtett Easter Eggek helyezhetőek el. Egy adott, különlegesebb teljesítmény eléréséért jelvény vagy „tiszti cím” utalható ki a felhasználónak. Napló használatával a tanulók nyomon követhetik aktuális pontszámukat és jegyüket, ami a fejlődésük visszajelzéseként is szolgál. Fórum és chat-szolgáltatással az online közösségi interakciók segíthetőek elő, az oktatók pedig a kvízekkel, beadandó feladatokkal, leckékkel, mühelymunkákkal és felmérésekkel mérhetik fel a hallgatók tudásszintjét. (Barna \& Fodor, 2019a)

A Moodle-ben található, gamifikálást támogató pluginek listája tartalmaz olyan modulokat, mely például az előrehaladást vizualizált szintlépéssel prezentálja, minijátékok formájában kérdezi vissza a kérdésbankban tárolt feladatokat, videós tananyagot tesz interaktívvá, tanulók által használható eszközkészletet implementál, vagy épp virtuális pénznemet vezet be a kurzusba. (Moodle, 2019)

Ezek a pluginek többnyire csak gamifikációs elemeket tartalmaznak, noha egy hatékonyan gamifikált alkalmazásnak ezek mellett játékmechanizmusokkal és játékdinamikákkal is szükséges rendelkeznie (ld. 0. fejezet), s jelenleg a Moodle nem tudja rendszerszinten támogatni a gamifikációt.

\subsubsection{Javasolt gamifikációs struktúra}

A jelenleg elérhető pluginek alkalmazásával a személyre szabott részletes és azonnali visszajelzés és motiválás nem valósítható meg. Köszönhetően az emberek különböző 
típusának, motivációjuk növelése eltérő módszereket követel meg. A motiváció megnyilvánulhat kisebb kihívások felállításában (pl. „Plusz 3 pontért cserébe gyakorolj a tesztekkel 5 egymás utáni napon!”), a fejlődés mértékének megjelenítésében, a grafikai interfész személyre szabásában, mellyel megadatik a felhasználó számára, hogy (korlátozott mértékben) a saját ízlésének megfelelően alakítsa a rendszert (grafikai dizájn témája, felhasználói szintek témája, avatár stb.). (Barna \& Fodor, 2019a)

A Moodle-lel kapcsolatosan a megvizsgált funkciók céljuk szerint négy kategóriába sorolhatóak (Barna \& Fodor, 2019a):

1) Fő cél támogatása (tanulás és fejlödés)

2) Szolgáltatás használatának támogatása (felfedezés)

3) Szociális kapcsolatok és interakciók biztosítása

4) Személyre szabhatóság érzésének elősegítése

Az alábbi listában szerepelnek az Alapelemek, a Meglévö pluginek, és a javasolt Elké-

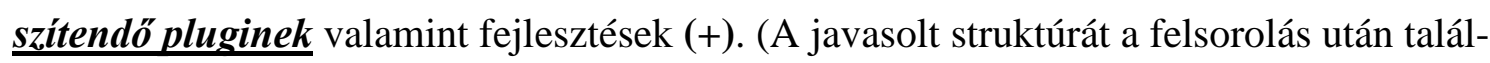
ható 38. ábra szemlélteti.)

\section{Motivált tanulás fejlődés és elismerés révén:}

- Egy e-learning rendszer fó funkciója, hogy adott témában Tudásanyagokat biztosítson egy többé vagy kevésbé strukturált szerkezetben. A Tartalomtérkép (avagy Tudástérkép) segít a tanulóknak áttekinteni a tudásanyagok mennyiségét, összefüggését, valamint egy anyag elsajátítása előtt megismerheti, milyen szükséges előfeltételei lehetnek. Akár már egy meglévő plugin segítségével Interaktív tudásanyagok készíthetőek belölük (pl. csatolt multimédiaelem; a hallgató megértését ellenőrző kérdés feltevése a tudásanyag feldolgozása közben). (Barna \& Fodor, 2019a)

- A Moodle rendszer rendelkezésre bocsát különféle Feladattípusokat, melyekkel leellenőrizhető a tanuló tudásszintje. Minijátékok(+) használata érdekesebbé, színesebbé teheti a kurzust, de ha nem megfelelően kerülnek alkalmazásra (pl. túlzott használat, erőltetett használat, eltérő témakör), komolytalanná tehetik a kurzusról alkotott összképet. (Barna \& Fodor, 2019a) 
- A feladatok teljesítésével a tanulók Pontokat szerezhetnek. A felhalmozódó pontjaikkal egyre magasabb Szinteket(+) és végső Érdemjegyet érhetnek el. (Barna \& Fodor, 2019a)

- A feladat teljesítése és a tesztek kitöltése mellett további Jutalom(+) helyezhető kilátásba, mely elősegítheti a tanulók megfelelő felkészülését, vagy felhasználható a diák tanulási folyamatának elismeréséül (pl. új színskála használata). A kurzus végső $\underline{\boldsymbol{C} e ́ l}$ ja a magas érdemjegy elérése, ám emellett $\underline{\text { Alcélok }}$ felállítása is szükséges. Ha a kurzus több egységre osztható fel, az alcélok lehetnek eme egységek teljesítése. Annak érdekében, hogy a tanuló könnyen és gyorsan informálódjon az aktuális (al)cél elérési folyamatában tett erőfeszítéseinek mértékéről, $\underline{\text { Fejlódésmutató }}$ segítségével vizualizálható számára. (Barna \& Fodor, 2019a)

\section{Motivált tanulás elköteleződés és felfedezés révén:}

- A Jogosultságkezelés segítségével a tudásanyaggyüjtemények egyes részeinek elérése bizonyos feltételekhez köthetö, mely a tanuló cselekedetein múlik, hogy teljesülnek-e vagy sem (úgymint egy adott Feladat teljesítése, vagy egy elöre meghatározott mértékü Pontszám elérése). (Barna \& Fodor, 2019a)

- Annak érdekében, hogy a tanulókat motiválni lehessen a nem kötelező feladatok elvégzésére (vagy legalább megtekintésére), Kihívások állíthatóak fel és megszerezhető Jelvények(+) tüzhetők ki (pl. minden teszt meglátogatása). (Barna \& Fodor, 2019a)

- Azon felhasználók számára, akik örömüket lelik a szolgáltatás minden pontjának felfedezésében, különféle Easter Egg(+) rejthető el, még inkább sarkallván a kurzus teljes felderítésért. (Barna \& Fodor, 2019a)

\section{Motivált tanulás szociális kapcsolatok és interakciók révén:}

- A társasági kapcsolatok lényeges szerepet játszanak a gamifikációban. A Moodle lehetőséget ad Fórum és Chat használatára, hogy a felhasználók tudjanak egymással a szolgáltatás felületén is információt cserélni. (Barna \& Fodor, 2019a)

- Csapatmunkát igénylő beadandó feladatok is csatolhatóak alapból egy-egy kurzushoz. (Barna \& Fodor, 2019a) 
- A kétirányú kommunikáció a tanulók és az oktatók között nem megfelelően támogatott az alapelemek segítségével. Érdemes lehetőséget adni a felhasználóknak, hogy küldhessenek Visszajelzést a tanároknak, valamint Értékelhessék a feladatokat és a tudásanyagokat. (Barna \& Fodor, 2019a)

\section{Motivált tanulás személyre szabás révén:}

- A Moodle alapesetben nem ad lehetőséget a kurzuson belül a felhasználói szintű Személyre szabásra, a felépített környezet a kurzus minden tanulójára érvényes. A grafikus interfész módosításának lehetőségével (pl. színséma, felhasználói szin-

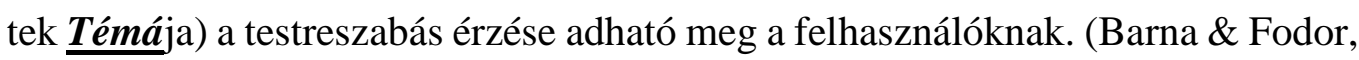
2019a)

- Az aktivált tudásanyagok és elvégzett feladatok alapján Személyre szabott teszteket lehetne automatikusan generálni, amivel a tanulók a saját fejlettségi szintjüknek megfelelően tudnák szinten tartani és fejleszteni a tudásukat. (Barna \& Fodor, 2019a)

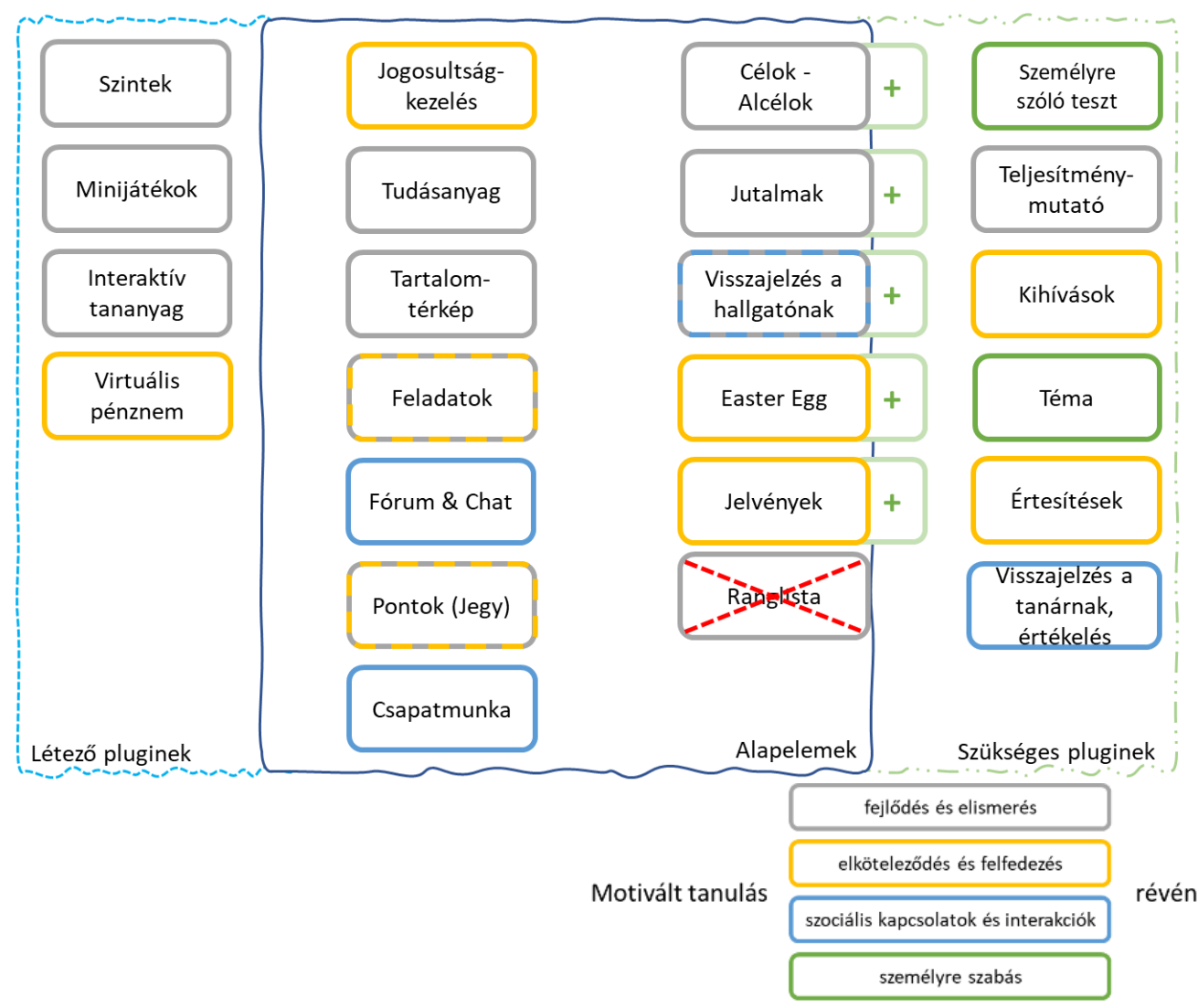

37. ábra: Javasolt gamifikációs struktúra a Moodle rendszerben jelenlévő alapelemek, létező pluginek és a szükségesnek vélt pluginek listájával (Barna \& Fodor, 2019a) 
Léteznek olyan erősen gamifikált komponensek, melyek a Moodle vizuális interfészének felépítése és/vagy az oktatás jellege miatt nem, vagy csak nehezen alkalmazhatóak, ilyen például a történetmesélés, különböző érzelmek használata, vagy a ranglista alkalmazása. A ranglistát kompetitív jellege miatt alkalmazzák, azonban az oktatás területén nem feltétlenül cél a másikkal „szemben állni”, a másiktól jobb lenni. Az oktatás során a tanulóknak önmaguk fejlesztése a cél, így önmagukat kell mindig „legyőzni”. Egy olyan tanuló, aki előzetes tudás-, képesség- vagy épp szerencsehiány miatt nem tudott az elején jó pozíciót elérni a ranglistán, őt akár demotiválhatja az a tény, hogy hiába öl bele maximális erőt a továbbiakban, az első helyezetteket már nem érheti utol, emiatt veszít lelkesedéséből, s így ez a gamifikációs elem motivációt csökkentő hatással fog rá bírni. Mivel az emberek többsége inkább Társasági mintsem Gyilkos játékostípusú (ld. 2.3.2. fejezet), így a kollaborációt segítő elemek használata a javasolt a kompetitív hatást kiváltó elemekkel szemben.

\section{2.Újraszervezett Informatika kurzus}

Az alábbi fejezetben egy egyetemi közegben megvalósított, meglévő kurzus gamifikálásának körülményeiről és eredményeiről esik szó. 2015-ben az „Informatika” nevezetü tantárgy módosítása történt meg a Moodle rendszeren belül, melyeken többnyire közgazdasági tudományokat hallgató diákok vesznek részt. A Moodle rendszerből átvett elért pontszámok, bukási arány, kurzusértékelések és hallgatói visszajelzések képezik a kutatás alapját. A vizsgálat során 2500 hallgató vett részt az átalakított kurzusban. Noha a gamifikáció önmagában nem tud megoldani minden problémát (szükség lehet a jó minőségü tudásanyag és megfelelő szintü tanítási készségre is), a kutatás eredményei azt sugallják, a gamifikáció hozzá tud járulni egy élvezetesebb kurzus kialakításához, valamint jobb általános végeredményt tud elősegíteni. (Barna \& Fodor, 2018a)

Az „Informatika” kurzus egy kötelező, egyféléves, alapképzés kezdetén oktatott tárgy, melyet a Gazdálkodástudományi Kar és Közgazdaságtudomány Kar minden nappali és levelezős hallgatójának szükséges elvégeznie. A kurzus (amin szemeszterenként átlagosan 1000-1500 hallgató vesz részt (ld. 12. táblázat)) 2015 őszétől kezdve „vegyes” vagy „kombinált” („,blended”) típusú oktatáselvet követ, kihasználván az internet és a digitális média nyújtotta előnyöket és lehetőségeket, kombinálván a személyes oktatást a számítógép-vezérelt irányadással (Bonk \& Graham, 2006), mindezt megtámogatva 
gamifikációs elvekkel. Ezutóbbi aspektus kialakításában és müködtetésében nyílt lehetőségem társként részt venni. A Gazdaságinformatikus hallgatók számára nem került imp-

\begin{tabular}{|c|c|c|c|}
\hline \multirow{2}{*}{ Év } & \multicolumn{3}{|c|}{ Részvétel } \\
\cline { 2 - 4 } & Nappali tagozat & Levelezős & Összesen \\
\hline 2015 & 1427 & 189 & 1616 \\
\hline 2016 & 1127 & 194 & 1321 \\
\hline
\end{tabular}

12. táblázat: Szemeszterenkénti hallgatószám az „Informatika” c. tantárgy esetén (Barna \& Fodor, 2018a)

lementálásra a gamifikációs környezet, ám a tananyag nem tért el a többi csoporthoz képest.

A vizsgált kurzusban a hallgatóknak hét darab előadást tartottak, emellett gyakorlati tananyagot kaptak hétről-hétre, melyet önállóan kellett elsajátítaniuk az oktatóplatform segítségével. A hallgatók értékelése a heti tesztekből, beadandókból és a végső vizsgából gyüjtött pontszám alapján történt meg. (Baksa-Haskó, 2017)

\subsubsection{Gamifikációs átalakítás lépései}

A kurzus felépítésében számos gamifikációs elem került alkalmazásra. Ezek egy része már korábban is szerepelt (pl. pontok) más elgondolás alapján, többségük azonban új elemként jelent meg. Felmerült a ranglista bevezetésének lehetősége is, ám a 6.1.3. fejezetben is felvetett elgondolás alapján úgy véltük, nem járulna hozzá megfelelően az átalakítás fó céljához.

\section{Jutalmazási rendszer: pontok, jelvények, szintek}

Az online felület jutalmazási rendszere pontozásra, jelvénygyüjtésre, valamint teljesítményen alapuló felhasználói szintekre épült. Pontokat a tesztek sikeres kitöltésével gyüjthettek. A megszerzett jelvények az adott tananyag-modulok teljesítése után járt, és plusz pontot jelentettek a félévvégi vizsgán. Az egyes modulokon belül elért tudásuk mértékét pedig az általuk kiválasztott témának megfelelö felhasználói szint tükrözte. 


\section{Alternatív tanulási útvonalak}

A kurzus egy tanulmányi részből és egy félévvégi vizsgarészből tevődik össze. A tanulmányi rész tanterve négy modulból tevődik össze, és a hallgatóknak mindegyik modulból el kell érniük egy minimumpontszámot annak érdekében, hogy teljesítettnek lehessen elkönyvelni a részt, s ezáltal vizsgázhasson a hallgató. (Barna \& Fodor, 2018a)

Mindegyik modulhoz tartoznak heti tesztek, valamint minor (ún. „mentőöv”) tesztek. A heti teszteket kétszer lehet kitölteni, és a jobb eredmény számít. A minor teszteken a próbálkozások száma nincs korlátozva, viszont függetlenül a kitöltések számától, maximum az adott modul teljesítéséhez szükséges minimumszintnek megfelelő pontszám gyüjthető össze. A szükséges minimumszint elérhető mindkét tesztfajta segítségével, azonban a magas szinteket és a legmagasabb szinthez járó jutalomjelvényt (ami plusz pontot ad a végső vizsgán (Barna \& Fodor, 2015)) csak a heti tesztekböl szerzett pontokkal érhetőek el. Ily módon a hallgatóknak többféle út adataik a minimum szintek teljesítéséhez, valamint az elszántabbak további díj reményében magasabb tudásszintre törekedhetnek. Egy-egy szemeszter során (mely 14 hétből állt) 13 heti tesztet és 28 minor („,mentőöv”) tesztet tölthettek ki a hallgatók. (Barna \& Fodor, 2018a)

A kétféle teszttípus mellett opcionálisan választható beadandó feladatok is várták a diákokat. Amennyiben a beadott munkát elfogadta az oktató, a hallgató újabb pluszpontot érő jelvénnyel gazdagodott. Ha egy diák összegyüjti az összes jelvényt (maximum 1 hiányozhat), akkor automatikusan megkapja a legmagasabb érdemjegyet a tantárgyból, ezzel kiváltva a vizsgarészét is a kurzusnak. (Barna \& Fodor, 2018a)

\section{Azonnali visszajelzés}

A hallgatók folyamatos visszajelzést kaptak a teljesítményük aktuális állapotáról, mely magába foglalta a modulonkénti elért eredményüket és rangjukat, valamint szöveges információt kaptak a további lehetőségekröl, mellyel még javíthatják saját pontszámukat.

\section{Visszajelzés témája}

A kurzusra jelentkezett felhasználók számára megadatott a lehetőség, hogy kiválaszthassák a számukra szimpatikus témáját a modulonkénti elért eredményen alapuló felhasználói szintek elnevezésének. Az alapértelmezett, egyszerü téma mellett választhattak 
népszerü fikciós témát (pl. Dumbledore professzorurat a Harry Potter szériában szereplő Roxfort iskolából), sportjellegü témát (pl. Judo szintek), vagy éppen üzleti vonatkozású szintneveket. A választható felhasználói témák csak 2015-ben váltak elérhetővé, akkor is kissé visszafogott hírveréssel. (Barna \& Fodor, 2018a)

\section{Társas interakciók: fórum és chat}

A fórum és a chat-szolgáltatás segítségével közvetlenebbé válhat a kapcsolat hallgató és hallgató között, valamint hallgató és oktató között.

\section{Kialakított gamifikációs struktúra}

A 6.1.3. fejezetben ismertetett javasolt Moodle gamifikációs struktúrát tekintve az Informatika kurzus átalakítása az alábbi felépítéssel zárult (38. ábra):

A Átalakítás előtt

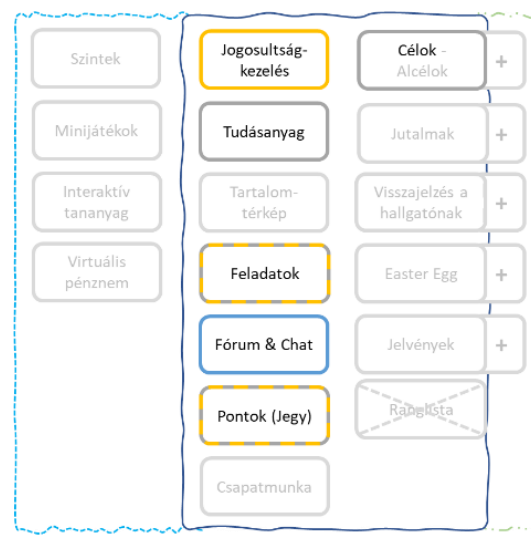

B Átalakítás után

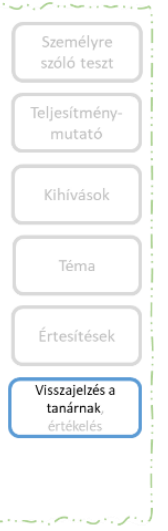

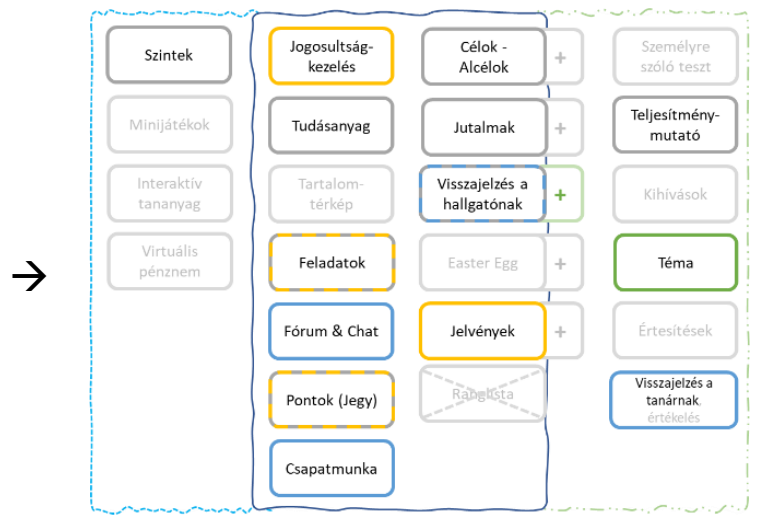

38. ábra: Az „Informatika” kurzus Moodle gamifikációs struktúrája az átalakítás előtt és után ((Barna \& Fodor, 2019a) alapján saját szerkesztés)

Az A panel az átalakítás előtti állapotot mutatja, míg a B panel az átalakítás utánit. Ebben a struktúrában expliciten nem jelenik meg az alternatív tanulási útvonalak bevezetése, ám technikailag az a Jogosultságkezelés átalakításával lett implementálva.

\subsubsection{A kutatás időszaka alatt bekövetkezett változások}

A 2016-ban induló szemeszterben 2015-höz képest bizonyos változtatásokra volt szükség, mely részben érintette a két félév összehasonlíthatóságát, ám pedagógiai szempontból prioritást élveztek. Az opcionális konzultációs lehetőségeken felül 2015-ben nem volt szisztematikusan felépített közvetlen, személyes interakció a gyakorlati tananyaggal 
kapcsolatban. 2016-ban két géptermi gyakorlati órán kötelező volt megjelenni a hallgatóknak, ahol kérdésekkel fordulhattak az instruktorokhoz, és csoportosan dolgozhattak a feladataikon. Mivel az első félévben kevesen éltek a felhasználói szint témájának kiválasztásával (nem volt egyértelmű a hallgatók számára, hogy lehet választani), ezért 2016ban csak az alap témaverzió került használatba. (Barna \& Fodor, 2018a)

\subsubsection{Hallgatói részvétel változása}

A kurzus iránti elköteleződési faktor változásának hatékonyságát a hallgatók aktivitási rátájának, valamint a kurzus tanulmányi részének bukási/teljesítési rátájának változásával jellemzi a kutatás. (Barna \& Fodor, 2018a)

\section{Visszajelzés és felhasználói szintek témája}

A hallgatók hat lehetőségből választhattak, milyen köntösben kívánják visszakapni a teljesítményükről szóló értékelést. Ha önmaguktól nem választottak, akkor az alapértelmezett téma vonatkozott rájuk. A témák listáját és az egyes opciókat választók listáját a 13. táblázat ismerteti. (Barna \& Fodor, 2018a)

A hallgatók mindössze 14\%-a választott aktívan a témák közül, míg 86\%-ukra - választás hiányában - az alapértelmezett téma vonatkozott. Ezenfelül több témát kifejezetten kevesen választottak. Az eredmények alapján alacsony érdeklődés mutatkozott a témák iránt a 2015-ös szemeszterben, így ez a funkció 2016 már nem képezte részét a kurzusnak. (Barna \& Fodor, 2018a)

\begin{tabular}{|c|c|c|c|c|c|}
\hline Téma & Választott? & $\begin{array}{c}\text { Nappali } \\
\text { tagozatos }\end{array}$ & $\begin{array}{c}\text { Levelező } \\
\text { tagozatos }\end{array}$ & Összesen & Összesen (\%) \\
\hline Alap & $\begin{array}{l}\text { Nem (alap- } \\
\text { értelmezett) }\end{array}$ & $\begin{array}{c}1227 \\
(85,98 \%)\end{array}$ & $\begin{array}{c}165 \\
(87,30 \%)\end{array}$ & 1392 & $86,14 \%$ \\
\hline Alap & \multirow{6}{*}{ Igen } & 48 & 6 & 54 & $3,34 \%$ \\
\hline Dumbledore & & 85 & 4 & 89 & $5,51 \%$ \\
\hline Anyagok & & 15 & 3 & 18 & $1,11 \%$ \\
\hline Kacsa & & 18 & 3 & 21 & $1,30 \%$ \\
\hline Üzleti & & 14 & 7 & 21 & $1,30 \%$ \\
\hline Judo & & 20 & 1 & 21 & $1,30 \%$ \\
\hline \multicolumn{2}{|l|}{$\ddot{O} s s$} & 1427 & 189 & 1616 & $100 \%$ \\
\hline
\end{tabular}

13. táblázat: Választható visszajelzési témák 2015-ben (Barna \& Fodor, 2018a) 


\section{Heti tesztek}

A hallgatók aktivitásának mérőszámát a tesztek kitöltésének hajlandósága, az egy hallgató által megtett próbálkozások száma adja. (Barna \& Fodor, 2018a)

Minden heti tesztet maximum kétszer lehetett kitölteni, és a két eredmény közül a jobban sikerült pontszám számított bele az összteljesítménybe. Megemlítendő, hogy a tesztek kitöltése nem kötelező érvényü, de nagyban hozzásegít a tanulmányi részhez köthető pontgyüjtéshez. (Barna \& Fodor, 2015)

2015-ben enyhe különbség jelentkezett a nappali tagozatos és levelezős hallgatók között (39. ábra $\boldsymbol{A}$ panel). Átlagosan a nappali tagozatos hallgatók 65,4\%-a (1,8\%-os heti szórással) töltötte ki legalább egyszer a heti teszteket. A levelezős hallgatók körében azonban nem mutatkozott olyan népszerünek a heti teszt. Az első héten szinte azonos rátát $(67,7 \%)$ nyújtottak, mint a nappali hallgatók $(67,3 \%)$ részvételt nyújtottak, ám ez a 8 . hétre lesülylyedt 37,6\%-ig. Az átlagos kitöltési rátájuk 57,2\% lett 8,1\%-os szórással. (Barna \& Fodor, 2018a)

A kurzus 2016-ban jobb elérést tudott felmutatni mindkét hallgatócsoport esetében, bár a köztük lévő különbség ennek ellenére erősödött. A nappali tagozatos hallgatók esetében 89,7\%-os átlagos kitöltési arányt értek el (4,0\%-os szórással), míg a levelezősök rátája 67,0\%-ig kúszott fel egy átlagos héten (szórásuk 9,2\%). Habár a kitöltési mutató majdnem folyamatos csökkenést mutat, a levelezős hallgatók 2016-ban produkált legrosszabb kitöltési aránya ért el közel azonos szintet, mint 2015-ben az átlagos szint (39. ábra $\boldsymbol{B}$ panel). (Barna \& Fodor, 2018a)

Átlagát tekintve azon hallgatók, akik a kitöltés mellett döntöttek, körülbelül 60\%-uk élt a második lehetőséggel, és e tekintetben nincs szignifikáns különbség a két típusú képzés között (Barna \& Fodor, 2015). Ugyanez igaz az évek közti összehasonlítás viszonylatában is. (Barna \& Fodor, 2018a)

\section{Minor „,mentőöv” tesztek}

A heti tesztekkel ellentétben a minor tesztek próbálkozási száma nincs korlátozva, bármennyiszer ki lehet tölteni, de egy teszttel maximum a heti teszt pontszámának negyede érhető el, bár így is elérhető egy modul minimumszintje csak a minortesztekkel. (Barna \& Fodor, 2015) 
A minortesztek kitöltési hajlandósága alulmarad a heti tesztekéhez képest, ám 2016-ban pozitívabb eredménnyel zárult az egy évvel korábbi teljesítményéhez képest. A nappali tagozatos hallgatók körében a 2015-ös szemeszterben $40 \%$ és 55\% között mozgott a legalább egyszer kitöltők aránya (39. ábra $\boldsymbol{C}$ panel). A levelezős hallgatókat vizsgálván tapasztalható, hogy a kitöltési rátájuk fluktuációja nagyobb tartományban inog alacsonyabb átlagértékkel, 25\% és 45\% között mozgott. (Barna \& Fodor, 2018a)

2016-ban az imént említett kitöltési arány a nappali tagozatosok körében 65-85\% között mozgott, míg a levelezősök esetén ez a ráta 40\% és 65\% közötti értékeket vett fel (39. ábra $\boldsymbol{D}$ panel). Ahogy megnövekedett részvételi arányt lehetett tapasztalni a heti tesztek esetén, ugyanez tapasztalható a minortesztek kapcsán is. (Barna \& Fodor, 2018a)

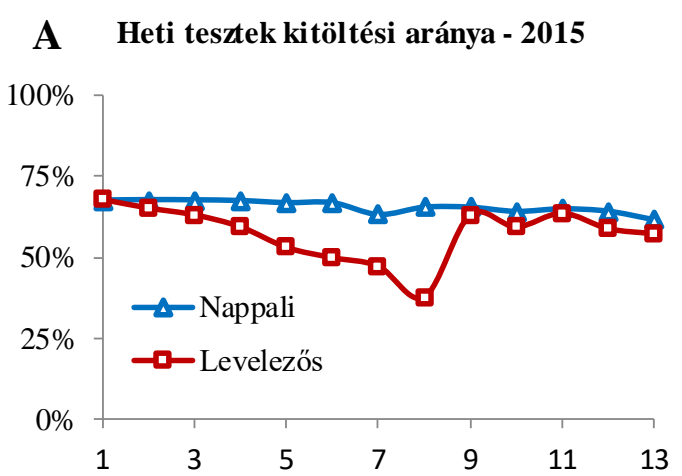

Heti tesztek sorszáma

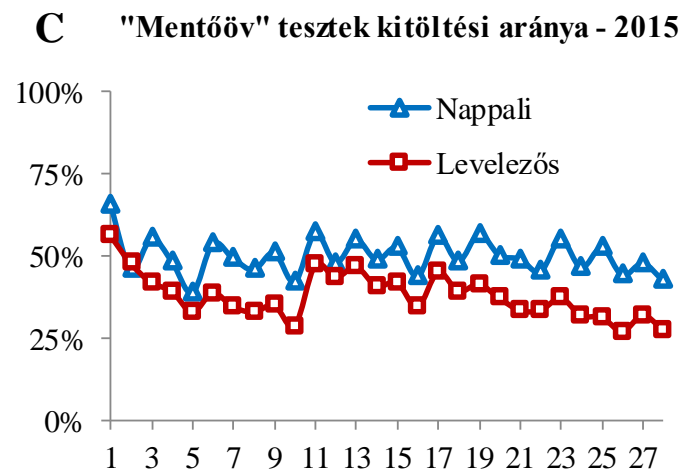

"Mentőöv" tesztek sorszáma

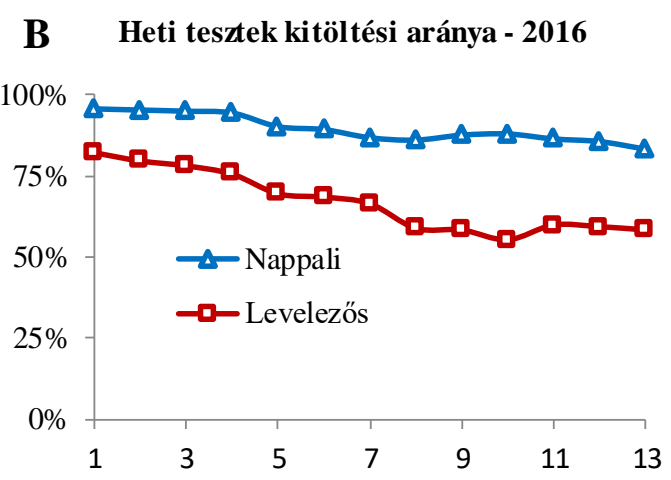

Heti tesztek sorszáma

D "Mentőöv" testtek kitöltési aránya - 2016

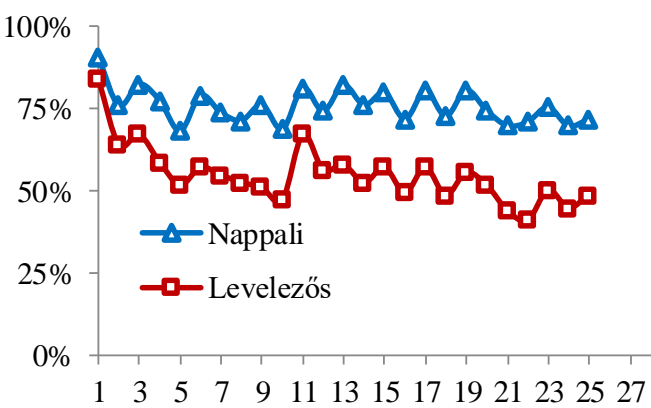

"Mentőöv" tesztek sorszáma

39. ábra: A heti és „mentőöv” teszteket legalább egyszer kitöltők aránya (Barna \& Fodor, 2018a)

\section{Évközi blokk teljesítménye}

A kurzus tematikája szerint a végső érdemjegy az évközi tanulmányi időszak alatt szerzett modulonkénti súlyozott pontszámból (30\%-os súllyal) és az évvégi vizsgán szerzett pontokból (70\%-os súllyal) áll. Az évközi teljesítménybe a pontszáma csak akkor számít bele, ha a hallgató minden modul esetén elérte a minimálisan megszabott pontértéket. Ha már 
csak egy esetében is elmarad a megkívánt legalacsonyabb szinttől, akkor az évközi teljesítménye 0-pontossá válik. (Barna \& Fodor, 2018a)

Az elköteleződés és hallgatói aktivitás mérésének egy másik szempontja lehet annak ellenőrzése, hogy mekkora aránnyal esnek el a hallgatók az évközi kurzusrészből szerezhető pontoktól, azaz hányan visznek 0 pontot a vizsgára. (Barna \& Fodor, 2018a)

2015-ben a résztvevők viszonylag magas aránya nem tudta elérni a szükséges minimális szintet mind a négy modulból. A nappali tagozatos hallgatók 34,5\% bukta el a pontszerzést, míg a levelezősök esetén 43,4\%-nak kellett lemondania az évközi pontokról. A következő évben a levelezősök elbukási aránya közel azonos szintű volt, 46,9\%, azonban jelentős javulás realizálódott a nappali tagozatos hallgatók esetében, őnáluk a 0-pontos évközi eredményt elérők aránya mindössze 13,6\% lett (40. ábra). (Barna \& Fodor, 2018a)

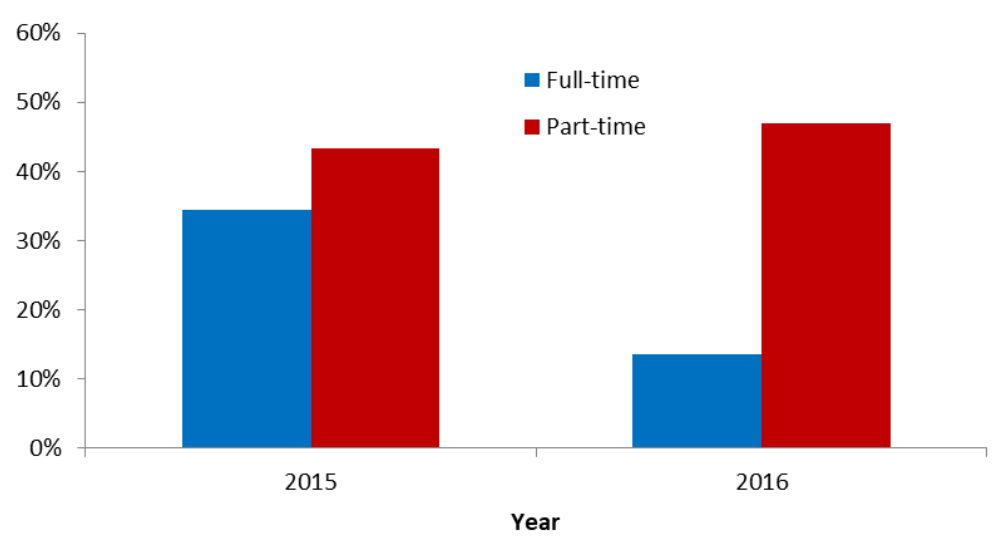

40. ábra: Évközi teljesítmény bukási aránya hallgatótípusonkénti bontásban (Barna \& Fodor, 2018a)

\subsubsection{Hallgatói elégedettség változása}

A hallgatói elégedettség mérése a „Hallgatói véleményezés (HalVel)” által lebonyolított és közzétett, oktatóra és kurzusra vonatkozó értékelések adatai kerültek felhasználásra. Ebben a kérdőívben a hallgatóknak számos kérdésre adtak választ. A kérdések skálaalapúak voltak, ahol az 1-es jelentette az adott állítással való ellenkezést, az 5-ös pedig az állítással való teljes egyetértést. (Barna \& Fodor, 2018a)

Ahogy a 6.2-es fejezetben elhangzott, az „Informatika” kurzus átalakítása után „vegyített” és gamifikált formában került oktatásra, ám ez alól kivételt képeztek a Gazdaságinformatikus szak hallgatói, kiknél a gamifikációs elemek nem jelentkeztek. Számukra a kurzus ugyanabból a tananyagból állt, emiatt a különböző oktatási módok összehasonlíthatóvá 
váltak, s megvizsgálható, miként hatott a gamifikálás a hallgatók elégedettségére. (Barna \& Fodor, 2018a)

Az elsajátított tananyag hasznosságérzetét tekintve a gamifikált kurzus hallgatói 9,9\%kal jobb értékelést adtak, valamint 4,9\%-kal jobbra értékelték az oktatói és hallgatói egyéni teljesítményértékelés összhangját. Emellett viszont az évközi feladatokat átlagosan 3,5\%-kal kevésbé találták élvezetesnek, mint a nem gamifikált kurzus hallgatói (14. táblázat). (Barna \& Fodor, 2018a)

\begin{tabular}{|l|c|c|c|}
\hline \multicolumn{1}{|c|}{ Kérdés } & $\begin{array}{c}\text { Gamifikált } \\
\text { kurzus átlagos } \\
\text { értékelése } \\
(1-5)\end{array}$ & $\begin{array}{c}\text { Nem gamifikált } \\
\text { kurzus átlagos } \\
\text { értékelése (1-5) }\end{array}$ & $\begin{array}{c}\text { Százalékos } \\
\text { különbség } \\
\text { (a gamifikált kurzus } \\
\text { szempontjából) }\end{array}$ \\
\hline $\begin{array}{l}\text { A tárgy keretében hasznos } \\
\text { dolgokkal foglalkozunk. }\end{array}$ & 4,08 & 3,71 & $9,92 \%$ \\
\hline $\begin{array}{l}\text { A tanáraim hasonlóképpen } \\
\text { vélekednek teljesítményemről, } \\
\text { mint én magam. }\end{array}$ & 3,97 & 3,79 & $4,87 \%$ \\
\hline $\begin{array}{l}\text { A tárgy és a kapcsolódó évközi } \\
\text { feladatok élvezetesek voltak } \\
\text { számomra. }\end{array}$ & 2,92 & 3,03 & $-3,54 \%$ \\
\hline
\end{tabular}

14. táblázat: „HalVel” kérdőív 2016. évi eredményeinek összegzése (Barna \& Fodor, 2018a)

\subsection{5. Összegzés}

A kurzus átalakítása sikerrel zárult. Amellett, hogy a tárgy logisztikai szempontból is rá volt kényszerülve az átalakításra, az alkalmazott módszerek nemcsak az oktatói gárda kérdésében értek el eredményt, de a hallgatói teljesítmény növekedését is el tudták érni. Az átalakítás során alkalmazott gamifikációs eszközök közül az alternatív tanulási utakat tekinthetjük a legerősebb és legeredményesebb változtatásnak. Azzal, hogy a tanulmányi pontot érő számonkérések többféleképpen is teljesíthetőek (heti és „mentőöv” tesztek), jobban kiaknázhatóvá váltak a hallgatóság eltérő tanulási módszereik és tanulási hozzáállásuk. Az újrapróbálkozás lehetősége nemcsak esélyt ad a diáknak, hogy magasabb pontszámot érjen el, de ráveszi arra is, hogy többet, többször foglalkozzon a tananyaggal. 
A reform érdekessége, hogy míg a nappali tagozatos hallgatók körében jelentősen javult az évközi blokk teljesítése, addig a levelezős hallgatók körében - noha a heti rendszerességü tanulás szintén javult náluk - ezen nem tudott változtatni. Mögöttes indoka lehet (bár az értekezés kereteiben nem kerül alátámasztásra), hogy a levelezős hallgatók amellett, hogy szintén élnek a tesztek kitöltésével és az újrapróbálkozások lehetőségével, a megfelelő felkészülést már nem tudják megejteni. A kurzus esetleges jövőbeni továbbfejlesztése kapcsán érdemes lehet bevezetni a „teljesítményalapú tudásanyag-feloldás” eszközét, mely csak akkor engedi a következő heti tudásanyagainak megtekintését, ha a tesztek segítségével elért egy szükséges minimális szintet (és mivel a „mentőöv” tesztek korlátlan számban újrapróbálhatóak, ez már csak jogosultságkezelési beállítás kérdése, amire a Moodle alkalmas is). Ennek segítségével a tanulmányi szakasz már egy korábbi fázisában kiváltható a hallgatóban a „lemaradás érzete”, melyet minél hamarabb szeretne majd leépíteni önmagában.

Noha a visszajelzési témák bevezetése később történt meg visszafogott hírveréssel, a Moodle vizsgált verziójának vizuális interfésze nem ad kellő lehetőséget ennek kiaknázására. A felhasználói szintek alkalmazása esetén a hallgatók által elért szintet jogi megfontolások miatt (miszerint egy hallgató teljesítménye nem kerülhet publikálásra oly módon, mellyel beazonosítható maga a hallgató) nem lehetne nyilvános a többi felhasználó számára (mivel a szintük a gyüjtött pontjaiktól függ), így azok csak magánjellegü információk lehetnek.

\subsection{WebSec, a saját fejlesztésü gamifikált oktatói platform}

A Moodle e-learning rendszer használatával végzett kutatás (ld. 6.2 fejezet) pozitív eredményeket tudott felmutatni (pl. megerősített heti rendszerességű tanulási hajlandóság), habár a rendszer használatának korlátai is megmutatkoztak. Egyik fő problémája, hogy a rendszer és a felkínált eszközei többnyire az aktuális tudásszint felmérésére szolgál a hatékony tanulássegítés helyett. Ezenfelül nem lehet kellően fejleszteni a funkcióit ahhoz, hogy egy erősen gamifikált szolgáltatás alakuljon ki belőle.

Ezen indokok miatt egy önálló, általam fejlesztett oktatóalkalmazás mellett született döntés, aminek feladata, hogy egy szakértő vagy oktató által megadott témakört bejárva segítse a felhasználót az előre elkészített tananyag elsajátítása során a motiváció felkeltésében és annak fenntartásában. Az elkészítendő alkalmazástól elvárás volt, hogy külső 
szakértő vagy oktató felügyelete nélkül is tudnia kell segíteni, vezetni, értékelni és viszszajelezni a felhasználót (Barna, et al., 2019), miközben kiváltja a játékosban a „flow” élményt (ld. 2.2.5. fejezet).

A jelenlegi leírásban a „felhasználó”, ,játékos”, „hallgató” és „diák” kifejezések arra a személyre utalnak, akikben megvan a hajlandóság a tanulásra és az alkalmazás használatára (akár külső és/vagy belső nyomás hatására) a tanulási folyamata során. (Barna, et al., 2019)

\subsubsection{Projekt leírása}

Az oktatóalkalmazás prototípusa egy körökre osztott webalapú játék, amely az internetbiztonság témakörét dolgozza fel (ám felépítése miatt viszonylag könnyen alkalmazható más témakörre alapuló játék előállítására is). Az alkalmazás felkészítésében először az oktatónak (vagy szolgáltatónak) implementálnia kell a szükséges tudásanyagokat és feladatokat, meg kell adni ezek hierarchikus sorrendjét, valamint témakörökre kell szeparálni őket. Ezek az anyagokat és feladatokat a játékmenet során több aktivitás is kiválthatja, úgymint egy új kör kezdete, egy térképelem megnyitása vagy egy adott feladat elvégzése (vagy elrontása). A játék első verziója a NAIST IPLab-ból ${ }^{13}$ Kadobayashi Youki professzorúr és Tan Omiya mesterszakos hallgató közremüködéseivel készült el. Maga a program megtervezése és megalkotása, univerzális felépítése, a tartalom szerkezetének megtervezése, valamint annak importálása és igazítása az én feladatom volt, Tan Omiya a tananyag (tudáscikkek és feladatok) előállításáért és a tesztelés levezényléséért felelt, Kadobayashi Youki professzorúr a tesztelés megszervezésében és a projekt felügyeletében vett részt. A prototípus a „WebSec” elnevezést kapta, és jelenleg online is elérhető ${ }^{14}$ japán nyelven. (Barna, et al., 2019)

\subsubsection{Technikai információk}

Az alkalmazás PHP programozási nyelvben íródott szerveroldalon, mely a Symfony nevezetü keretrendszer 3-as verzióját használja. A kliensoldali megjelenítést a HTML és CSS szolgáltatja, az interaktivitás JavaScript és a jQuery könyvtár használatával valósult

\footnotetext{
${ }^{13}$ Nara Institute of Science and Technology (NAIST), Laboratory of Cyber Resilence (IPLab), https://iplab.naist.jp/

${ }^{14} \mathrm{http}: / /$ websec.infora.hu
} 
meg. Az adatok kezeléséről egy MySQL adatbázis gondoskodik. A felhasznált háttérképeket „iconicbestiary” nevezetü felhasználó készítette a „Freepik” nevezetü oldalon ${ }^{15}$, felhasználása ingyenesen megengedett. (Barna, et al., 2019)

\subsubsection{Folyamat és játékelemek}

Az alábbiakban a játék tervezése és megvalósítása során felhasznált gamifikációs elvek és elemek ismertetéséről esik szó, az egyes leírások végén a használt elemek címszavakban szerepelnek.

A „WebSec” játékban a játékos egy újonnan felvett munkavállalót alakít egy cégnél. A játékmenete során folyamatosan szinten kell tartania és fejlesztenie kell az internetbiztonsággal kapcsolatos tudását annak érdekében, hogy „,biztonságos” munkavállalója legyen a cégnek, és ne jelentsen biztonsági kockázatot a cég számára. A játék célja, hogy minden tudásanyagot aktiváljon a felhasználó, és teljesítsen minden feladatot a lehető legtöbb pont elérése mellett. [történet, cél] (Barna, et al., 2019)

A felhasználóknak a játékmenet során több kulcs-folyamatindikátorra (KPI) kell ügyelnie, úgymint a „pénz (money)” mértéke (pontok), a cég „,biztonsági elégedettsége (security satisfaction)" a játékos iránt, valamint a ,,tolerancia zseton (tolerance tokens)” mennyisége. A legkritikusabb KPI ezek közül a „,biztonsági elégedettség”, ami egy százalékos mutató. Ha ez a mutató eléri a nullát, a cég elveszti minden bizalmát a munkavállalója iránt, és a játék véget ér. Minél magasabb ez az érték, annál megbízhatóbbnak tartja a cég. A „,tolerancia zsetonok” segítenek csökkenteni a rossz döntések negatív hatásait. Ha a játékos kifogy ezekből a zsetonokból, akkor a cég egyre kevésbé tolerálja az alkalmazottja által elkövetett hibákat, így a „,biztonsági elégedettség” mértéke is nagyobb mértékben csökken. A „tolerancia zsetonok” célja, hogy megbocsássa az alkalmi hibázásokat, de büntesse a folyamatos rossz döntéseket (amit az elvárt tudás hiánya okoz). (Barna, et al., 2019) Egy rossz döntés meghozatalakor várható visszajelzést szemléltet a 41. ábra. [sza-

\section{bályok, pontok, KPI, megbocsátás/újrapróbálkozás]}

\footnotetext{
15 https://www.freepik.com/
} 


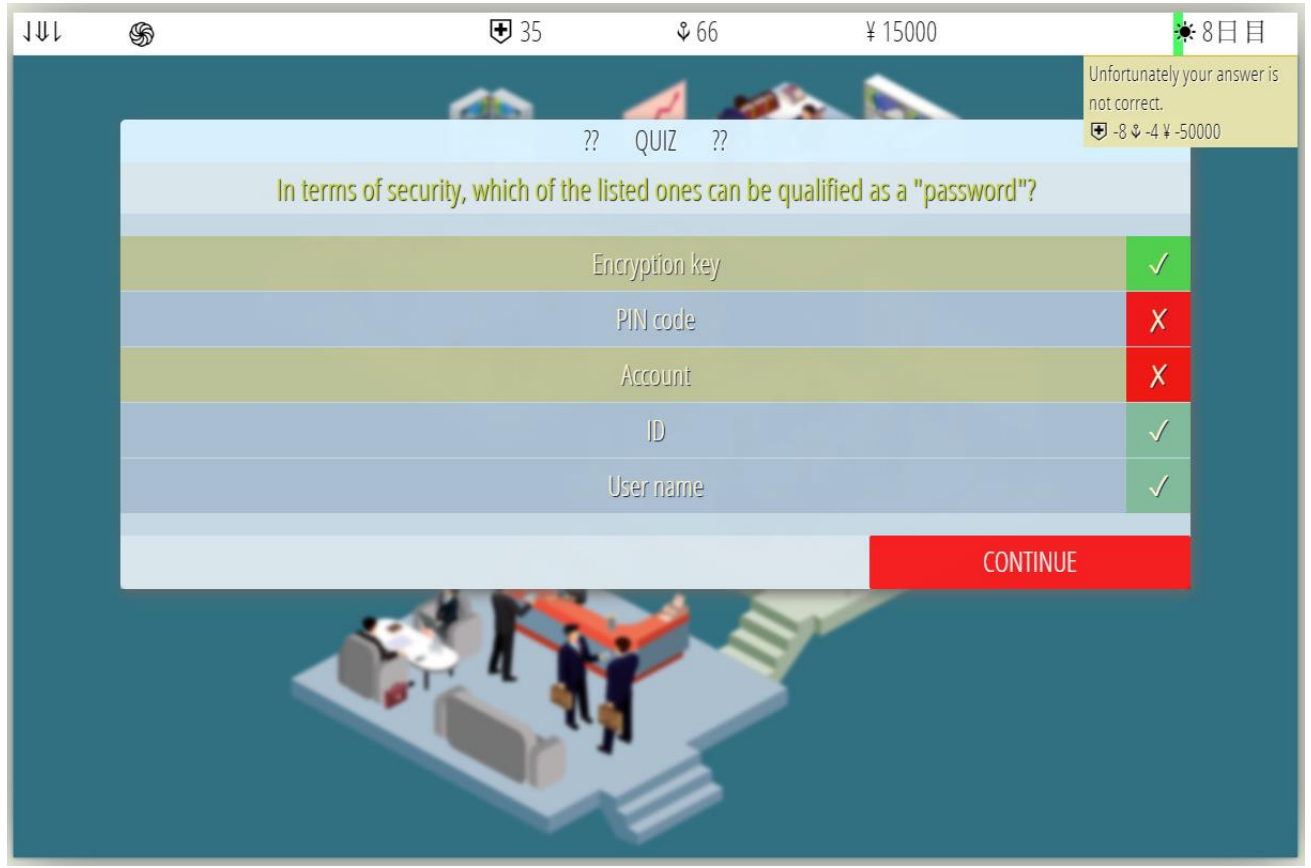

41. ábra: Egy rosszul megválaszolt kvízkérdés, mely mutatja a helyes és helytelen jelöléseket, valamint tájékoztat a kapott büntetésről a jobb felső sarokban. (Barna, et al., 2019)

A játékmenet elindulása után a felhasználó a vállalat térképén találja magát, melyen kattintható térképelemek szerepelnek. A felső sorban találja a KPI-ok aktuális értékét, valamint egy időmutatót, mellyel a játékbéli napok múlását lehet nyomon követni (valamint a segítségével állítható meg ideiglenesen a játékmenet is). A térképelemek egy-egy témakörspecifikus könyvtárat nyit meg, vagy épp tovább vezet egy másik térképfelületre. [felfedezés, tudástérkép] (Barna, et al., 2019)

Minden kör elején a „, biztonsági elégedettség” és a „pénz” mértéke valamelyest csökken, fenntartva a késztetést a további tanulásra és még több feladat megoldására. Az aktivált tudásanyagok alapján a játék feladatokat oszthat ki vagy új anyagok elérését teheti lehetővé. Az alkalmazás jelenlegi állapotában a feladatok lehetnek feleletválasztós kérdések (egy válasz / több válasz), szövegesen megválaszolandó kérdések, valamint összefüggő kvízkérdések, melyek esettanulmány-jellegüen tudnak müködni. [idő, folyamat, tanulás, feladat] (Barna, et al., 2019)

A feladatok során a játékos mindig kap visszajelzést a döntéséről, akár helyes volt, akár nem. A helyességtől függően a játékos jutalomban (KPI-növekmény) vagy büntetésben (KPI-csökkenés) részesülhet. Ha nem tudott jó választ adni, akkor a következő körökben ismét felbukkan ugyanaz a feladat mindaddig, amíg a helyes választ meg nem tudja adni 
rá. A helyesen meghozott döntések új tudásanyagok feloldását teheti lehetővé. [visszajelzés, következmények, jutalom] (Barna, et al., 2019)

A feloldott tudáselemek elérhetőek a tudáskönyvtárban, ami tartalmazza az egyes cikkeket témakörök szerinti bontásban. Az egy-egy témakör alá tartozó anyagok összes száma, és az ezekből adott pillanatban a felhasználó számára megnyitott anyagok száma megjelenik a témakör mellett, jelezvén ezzel is, hogy milyen szinten áll a játék feldolgozottsága terén. [tudás, tudástérkép, előrehaladás]

Az alkalmazás fejlettségét szemlélteti a 42. ábra, mely időrendben tartalmazza a beépített és a tervezett elemeket, szemléltetve azok kidolgozottsági szintjét.

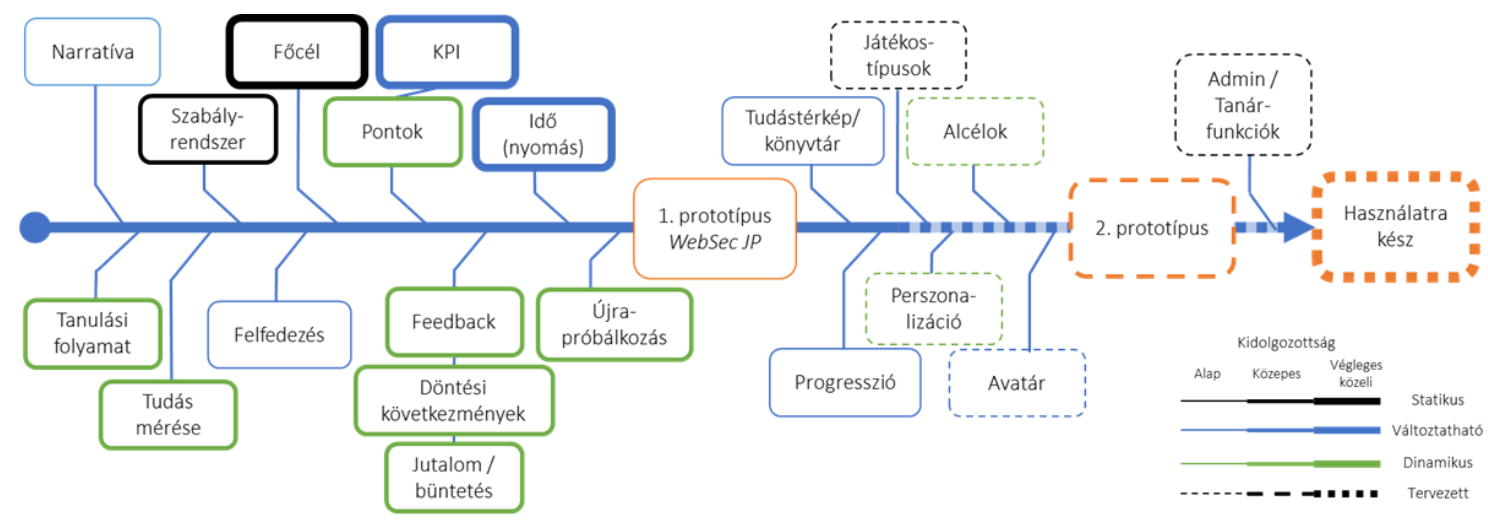

42. ábra: „WebSec” oktatóalkalmazás fejlettsége (Saját ábra)

\subsubsection{Első verzióval szembeni elvárások}

Annak érdekében, hogy vizsgálhatóvá lehessen tenni az első verzió müködőképességét, néhány elvárás előre meg lett határozva vele szemben. Az első két elvárás az alkalmazás használhatóságát vizsgálja, míg a harmadik a gamifikáció hatékonyságnövelését hivatott elemezni. (Barna, et al., 2019)

1) A felhasználó érez egy legalább 60-perces játékmenet játszásához hajlandóságot.

2) Egy új játékmenet indításakor hosszabb ideig játszik vele, mint előző alkalommal.

3) A felhasználó egységnyi idő alatt hatékonyabban tudja elsajátítani a tananyagot, mint egy szakértő által tartott elöadás során.

Az alkalmazás tesztelése egy alkalommal történt meg japán hallgatók által. Eme teszt során az alkalmazás használhatósága és hasznossága, valamint az imént említett elvárások közül az 1)-esnek és a 2)-esnek való megfelelés került vizsgálatra, a 3)-as számú elvárás vizsgálatára még nem került sor. (Barna, et al., 2019) 


\subsubsection{Gyakorlati alkalmazása}

Az alkalmazás két csoportban került tesztelésre, egyenként 8 hallgatóval különböző japán egyetemekről ${ }^{16}$. A hallgatóknak korlátozott mennyiségű idő állt rendelkezésre a kipróbálásra, és a két csoport egyidőben használta. (Barna, et al., 2019)

A 16 játékos 43 játékmenetet indított el, 26 esetében legalább 5-körösek voltak. Mivel a játékot nem lehet 5 kör alatt befejezni (sem sikerrel, sem kritikus elbukással), ezért az 5nél kevesebb körrel bíró játékmenetek nem számítódnak komoly próbálkozásnak, így azok nem képeznek megfelelő elemzési alapot. Ettől fogva a továbbiakban csak azok a játékmenetek képezik a vizsgálatok tárgyát, melyekkel legalább 5 kört lejátszottak. (Barna, et al., 2019)

\subsubsection{Időtartam}

Minden hallgató rendelkezett legalább 1 darab minimum 5-körös játékmenettel, átlagosan 1,63 menettel bírtak. Ezen játszmák átlagos hossza 72,65 kör, meglehetősen nagy szórással (45,63 kör).

A játékmenetekbe ölt idő mértéke változékony. A legrövidebb játékmenet 3 percig tartott, míg a leghosszabb 95 percig, 16 esetében (62\%) legalább 30 percen keresztül tartott, 12 esetében (46\%) pedig elérte az egyórás időintervallumot (43. ábra $\boldsymbol{A}$ panel). Az átlagos játszmaidő 47 perc volt, 29 perces szórással. (Barna, et al., 2019)

Belátható, hogy az alkalmazás alkalmas arra, hogy hosszabb ideig használják, akár 30-60 percig, viszont megjegyzendő, hogy ezek az alkalmak oktató által voltak felügyelve, és a hallgatók fö feladata az alkalmazás használata volt. (Barna, et al., 2019)

\footnotetext{
${ }^{16}$ Nara Institute of Science and Technology (Ikoma) - 10 fö; Institute of Information Security (Yokohama)
} -3 fö; Keio University (Tokyo) - 1 fö; Osaka University (Osaka) - 1 fö; Kyoto University (Kyoto) - 1 fö 


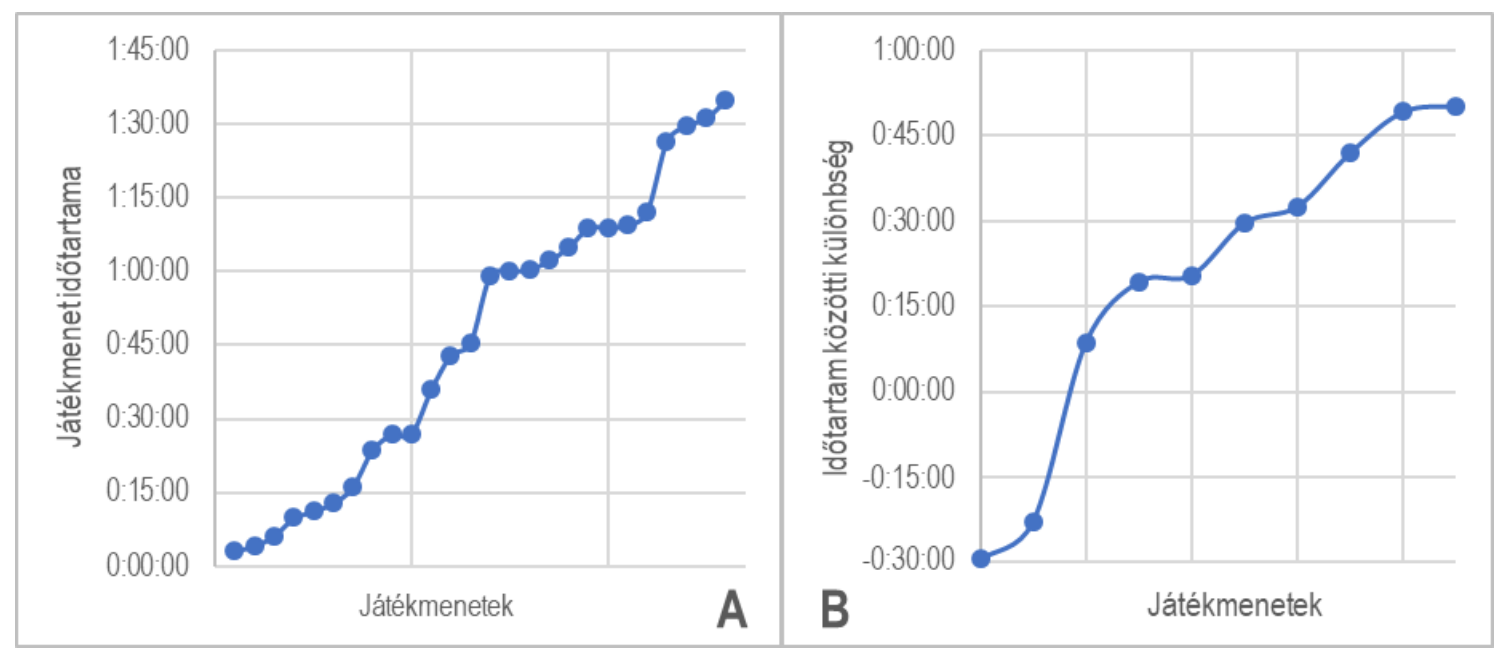

43. ábra: A) Játékmenetek időtartamuk szerinti sorrendben; B) Újrakezdett játékmenetek az egymásutáni játékmenetek közötti időtartamkülönbség szerinti sorrendben (Barna, et al., 2019)

Az újrapróbálkozásokat tekintve 6 felhasználó indított újra játékmenetet összesen 10 alkalommal. A 10-ből 8 esetében az előző játékmenetükhöz képest hosszabb időtartammal rendelkezett. Az újrakezdett játékmenetek átlagosan 20 perccel tartottak tovább az őket megelőzőknél (43. ábra B panel). (Barna, et al., 2019)

\subsubsection{Előrehaladás}

Az alkalmazásba 10 témakör köré szervezve 198 tudáscikk került implementálásra. A játékmenetek 77\%-ban a tudáscikket kevesebb mint felét sikerült aktiválniuk, ám volt olyan eset, amikor a felhasználó 98\%-ban aktiválta őket. (Barna, et al., 2019)

A játékmenetek során 124 különböző feladatot aktiváltak. A játékosok ezeket a feladatokat összesen 1266 alkalommal válaszolták meg, 67\%-ukban helyesen, ami azt jelenti, hogy az esetek több mint felében a felhasználók elsőre meg tudták válaszolni helyesen a kérdéseket. Hozzávetőlegesen az esetek harmadában nem tudtak jó választ adni. Az eszköz célja nem az, hogy olyan feladatok elé állítsa a felhasználót, amely megakasztja őt a folyamatban, ily módon, ha szerepelnek olyan kérdések, melyek többszöri nekifutásra sem sikerülnek, felül kell vizsgálni azt az adott feladatot. Ellenben, ha a feladatok túl egyszerüek, nem tudják megfelelően mérni az adott tudásanyagot. (Barna, et al., 2019)

\subsubsection{Prototípus kiértékelése}

A 6.3.1.3. fejezetben három elvárás került megfogalmazásra. Az első az időalapú használhatóságra utal, miszerint használható-e az alkalmazás legalább 60-perces 
játékmenetekre. Az eredmények azt mutatják, hogy 46\%-a a játékmeneteknek 60 percnél tovább tartott, ám a teszt felügyelt szituáció volt, így valamelyest külső hatás nyomása is fennállt. Ezek alapján lehetséges az alkalmazást legalább 60 percen át használni, de ez egyelőre csak a technikai használhatóságát igazolja, nem a felhasználó elköteleződését. Kevésbé felügyelt környezetben további tesztalkalmakra lenne szükség. (Barna, et al., 2019)

A második elvárás az újrapróbálkozást vizsgálja, miszerint a felhasználó által játszott újbóli játékmenet hosszabb időre le tudja kötni, mint az előző játékmenet. Azokban az esetekben, ahol új menetet indítottak egy sikertelenül végződött játszma után, 80\%-ukban átlagosan 20 perccel tartott tovább a játékidő. Ez alapján nem elvethető a második elvárás teljesíthetősége, ám szignifikánsabb eredményhez nagyobb minta szükségeltetik. (Barna, et al., 2019)

További kutatás szükséges a harmadik elvárás vizsgálatához, ahol kontrollcsoport alkalmazására is szükség lesz. A kontrollcsoport egy internetbiztonságról szóló előadáson / tanórán fog részt venni, míg a másik csoport ugyanabban az időben az alkalmazást fogja használni. (Barna, et al., 2019) 


\section{7. ÖSSZEFOGLALÁS}

A gamifikáció számos területen hasznosítható. Eme értekezés 2(+1), egymástól eltérö, speciális esetben vizsgálta meg a játékosítás lehetőségeit. A két irányvonal célcsoportja, a velük kapcsolatban vizsgált hatás és a kutatások célja merőben eltérnek egymástól. Az alábbi táblázat összefoglalja a kutatási irányvonalak főbb jellemzőit (15. táblázat):

\begin{tabular}{|c|c|c|}
\hline 1. Vállalati közeg & 2. Oktatás (Moodle) & +1. Oktatás (WebSec) \\
\hline \multicolumn{3}{|c|}{ Célcsoport } \\
\hline $\begin{array}{l}\text { - } 25-44 \text { év } \\
\text { - Irodai alkalmazottak IT / ta- } \\
\text { nácsadás területen }\end{array}$ & $\begin{array}{l}\text { - } 18 \text {-25 év } \\
\text { - Egyetemista hallgatók }\end{array}$ & - Egyetemista hallgatók \\
\hline \multicolumn{3}{|c|}{ Kutatások célja(i) } \\
\hline $\begin{array}{l}\text { - Elköteleződés támogatása a } \\
\text { munkahelyi légkör és az } \\
\text { egyének kapcsolati hálójá- } \\
\text { nak javításával } \\
\text { - Viselkedésalapú kategorizá- } \\
\text { lás }\end{array}$ & $\begin{array}{l}\text { - Folyamatos és eredményes } \\
\text { tanulási hajlandóság erösí- } \\
\text { tése }\end{array}$ & $\begin{array}{l}\text { - Edukációs platform } \\
\text { létrehozása }\end{array}$ \\
\hline \multicolumn{3}{|c|}{ Kívánt hatás fenntartási ideje } \\
\hline - Hónapok, Évek & - Félév / 12 alkalom & - Néhány alkalom \\
\hline \multicolumn{3}{|c|}{ Gamifikációs fókusz } \\
\hline $\begin{array}{l}\text { - Közösségépítés, részvétel- } \\
\text { erösítés }\end{array}$ & - Rendszeres használat & - Flow-élmény \\
\hline
\end{tabular}

15. táblázat: Kutatási irányvonalak összefoglaló felvezetése (Saját szerkesztés)

A kutatási irányvonalak munkái során elért eredményeket foglalják össze a következő alfejezetek.

\subsection{Vállalati közeghez kapcsolódó kutatások eredményei}

Az üzleti oldalhoz kapcsolódó kutatásaim két nagyobb kérdéskör köré tömörültek, melyek egy gamifikált online szolgáltatás közösségre gyakorolt hatását elemezték. Az első kérdéskör $\left(K_{V} 1\right)$ a munkavállalók viselkedésre, azok elköteleződésére való ráhatás két aspektusának lehetőségével hivatott foglalkozni, egyrészt a munkahelyi légkör befolyásának lehetőségével $\left(\mathrm{K}_{\mathrm{V}} 1_{\mathrm{A}}\right)$, másrészt a munkavállalók kapcsolati hálójára történő ráhatást vizsgálta $\left(\mathrm{K}_{\mathrm{V}} 1_{\mathrm{B}}\right)$. Az említett témakörben az alábbi eredményeket sikerült elérni: 
Ev1 $\left(\leftarrow K_{v} 1_{A}\right):$ A vizsgált gamifikált csapatépítő online szolgáltatást használó munkavállalók saját véleménye alapján több mint 61\%-uk gondolja úgy, hogy a szolgáltatás használata óta javult a munkahelyi légkör, és évek távlatában is fennáll a pozitív változás. (ld. 5.5. fejezet)

Ev2 (广Kv1в): A vizsgált gamifikált csapatépítő online szolgáltatás használata során a munkavállalók több mint 84\%-a ismerkedett meg legalább 1 részben vagy teljesen ismeretlen munkatársával. A szolgáltatást használók közel 31\%-a legalább 6 részben vagy teljesen ismeretlen munkatársával létesített szorosabb kapcsolatot. (ld. 5.7.1. fejezet)

Ev3 $\left(\leftarrow K_{v} 1_{B}\right):$ A vizsgált gamifikált csapatépítő online szolgáltatás használata során a munkavállalók több mint 80\%-a számolt be arról, hogy javult a kapcsolatuk azokkal a munkatársakkal, akikkel a szolgáltatás használata során közvetlen kapcsolatba kerültek. (ld. 5.7.1. fejezet)

Az egyének mozgással, sportolással kapcsolatos szokásbéli változása is elemzés tárgyát képezte, megvizsgálván, hogy rendelkezik-e a szolgáltatás motivációs ráhatással ezek terén, azaz javítja-e a hajlandóságot a mozgásjellegü aktivitások növelésére:

Ev4 (૯Kv1): A vizsgált gamifikált csapatépítő online szolgáltatás használata során a munkavállalók 62\%-a nyilatkozott úgy, hogy a szolgáltatás által keltett motiváció miatt többször tettek meg bizonyos, a szolgáltatás által kért, mozgásjellegü aktivitásokat, azaz ő bennük sikerült növelni a részvételre vonatkozó belső késztetést. (ld. 5.8. fejezet)

Ev5 (广Kv1): A szolgáltatás által megrendezett mérkőzéseken résztvevő felhasználók elégedettsége és a (felhasználói szintek és aggregált pontok alapján mért) tapasztalatai között nincs szignifikáns együttmozgás, így egy kezdő felhasználó ugyanúgy élvezi az aktivitásokat, mint egy tapasztaltabb. A mérkőzéseket a felhasználók közel 93\%-a pozitív élményként éli meg. (ld. 5.9. fejezet)

Az elégedettség mellett a munkavállalók viselkedésének elemzése és kategorizálása (Kv2) történt meg, amivel kapcsolatban az alábbi eredmények születtek:

Ev6 (ŁKv2): A felhasználók viselkedése alapján a felhasználók között a BrainHex modellbe illeszkedő 3 játékostípust lehetett behatárolni: „Győztes”, „Társasági” és „Teljesitö” (ld. 5.4.2. fejezet). 
Eme 3 klaszter mellett képződött egy 4. is, melynek tagjai (adatbányászati eszközök segítségével is leellenőrizve) az adott szervezetek „hivatalos” szervezői voltak, így ők a játékostípus szerinti viselkedésvizsgálatokból kikerültek, ám szerepük korántsem jelentéktelen.

Ev7 ( $\leftarrow$ Kv2): Az elkötelezettség arányára pozitív hatással bír a „szervezői” faktor. A vizsgált gamifikált szolgáltatás jobb eredményt tud elérni, ha az adott szervezet néhány tagja szervezöi feladatokat lát el (ld. 5.4.3.fejezet).

A felhasználók a regisztrációjuk során 2 ütemben egy-egy kérdőívet töltöttek ki. Ennek az eredményeit vetette össze az értekezés a tényleges viselkedésükkel annak érdekében, hogy megállapítsa, mennyire hatásosak a viselkedések elörejelzésére, csoportosítására. A viselkedésvizsgálat kitért az aktivitásokban történő részvételi hajlandóságra (egyéni és csapatalapú „race”, valamint „versus” versenyek, közösségi események), a közösségi funkciók használatára, a gyüjtött jelvények számára, valamint az elért játékosszintre.

Ev8 ( $\leftarrow$ Kv2): A kérdéssorok elemzése során a 2. kérdőív bizonyult a hatékonyabb jellem-behatároló hatásúnak. Kimutatható, hogy akik már a regisztráció kezdetén a csapat tagjának érzik magukat, nagyobb mértékben használják a közösségi funkciókat, valamint nagyobb hajlandóságot is mutatnak a különféle aktivitásokban való részvételekre, mint azok, akik még nem ismerik igazán jól a kollégáikat. Azok körében, akik egy „unalmas szombat délutánt” inkább szórakozással töltenének mintsem produktivitással, típustól függetlenül látványosan nagyobb részvételt tanúsítanak. Míg a bonyolult feladványt bevállaló felhasználók nagyobb kedvet éreznek az egyéni és csapatos „race” versenyek és a közösségi események iránt, valamint több jelvényt gyüjtenek, addig a feladvánnyal foglalkozni nem kívánók inkább az egy-az-egy elleni („,versus”) típusú megmérettetések hívei, ám mindemellett teljes érdektelenséget mutatnak a közösségi funkciók használata iránt. Várhatóan magas általános részvételi hajlandóságot fog tanúsítani az a felhasználó, aki az 1. kérdéssor esetében a C-25 kombinációt adja válaszul, vagy a 2. kérdéssor esetében a C-17 vagy a C-25-ös válaszegyüttest adja meg. (5.5. fejezet) 


\subsection{Oktatáshoz kapcsolódó kutatások eredményei}

Az oktatással kapcsolatos kutatásaim három részterületből tevődnek össze. Először az egyetemek széles körében használt Moodle-rendszer gamifikációs szempontú használhatóságának jellemzése történik meg. Ezt követően egy nagylétszámú kurzus átalakításának lépéseit, valamint az átalakítás eredményességének jellemzését taglalja az értekezés, s végül az e-learning rendszerből kilépve egy saját platform megvalósítását ismerteti a dolgozat.

Eo1: A Moodle-rendszer lehetőségeinek felmérését követően felállítottam egy javasolt struktúrát (38. ábra), mely alapján egy megfelelően gamifikált kurzus állítható fel a Moodle rendszer keretein belül. (ld. 6.1.3. fejezet)

\subsubsection{Moodle kurzus gamifikálásának eredményei}

Eo2 (†Ko1): Megtörtént a kurzus gamifikálása. Többféle játékelem és játékmechanika került implementálása (ld. 6.2.1. fejezet). A bekövetkezett változások oka soktényezős, de kimutathatóak benne a gamifikáció hatásai és a részvételi hajlandóság növekedése is (ld. 6.2.3. fejezet).

Eo3 (૯Ko2): Az elsajátított tananyag hasznosságérzetének megítélése kapcsán a gamifikált kurzus hallgatói 9,9\%-kal jobb értékelést adtak, mint a nem gamifikált kurzuscsoport hallgatói. (ld. 6.2.4. fejezet)

Eo4 (৮Ko2): A gamifikált kurzusban résztvevő hallgatók 4,9\%-kal pozitívabban értékelték az oktatói és hallgatói egyéni teljesítményértékelések között fennálló összhangot, mint a nem gamifikált kurzuscsoport hallgatói. (ld. 6.2.4. fejezet)

\subsubsection{Oktatójáték eredményei}

Eo5: Megalkottam a gamifikált keretrendszer első prototípusát, amely alkalmas különböző témakörű tananyagok implementációját követően azok átadására. A technikai paraméterek az első felhasználási területhez, a japán elvárásokhoz illeszkedtek, melynek során japán hallgatók használták az internetbiztonság alapjainak elsajátításához. (ld. 6.3.1. fejezet) 
Eo6: Az alkalmazás alkalmassá vált legalább 60-perces játékmenetek játszására, valamint a felhasználók megismételt játékmenete átlagosan 20 perccel tartott tovább az előző próbálkozásnál. (ld. 6.3.2.3. fejezet)

\subsection{További fejlesztési tervek és irányok}

A vállalati közegben eszközölt, egy cégre vetített kapcsolati hálózatot és „emberi együttmozgást" elemző kutatást érdemes kiterjeszteni több szervezetre. Ezzel megvizsgálhatóvá válna, hogy adott típusú aktivitások és adott méretü szervezetek esetén mekkora „klikkesedés”, részcsoportképzés várható. A „First Use Tour” során használt jellemfelmérő kérdések újragondolását célszerü megtenni, alapul véve az értekezés során is ismertetett tényekkel.

A Moodle-rendszerben kezelt kurzusok esetében javasolt megvizsgálni egy olyan felépítési elvet, mely során a hallgatók számára nem magától értetődő a tudásanyagokhoz való hozzáférés, hanem a kurzus korábbi anyagainak elsajátításához lehetne kötni („teljesítményalapú tudásanyag-feloldás").

A „WebSec” elnevezésű oktatói platform továbbfejlesztését tervezem megtenni, majd felkészíteni oly módon, hogy az internetbiztonságtól eltérö témát is fel tudjon dolgozni, majd európai hallgatóság körében tesztelés alá vonnám. 


\section{IRODALOMJEGYZÉK}

Abramovich, S. J., Schunn, C. D. \& Higashi, M. R., 2013. Are badges useful in education?: It depends upon the type of badge and expertise of learner. Educational Technology Research and Development, 61(2), pp. 217-232.

Aon, 2018. 2018 Trends in Global Employee Engagement. [Online]

Available at:

http://images.transcontinentalmedia.com/LAF/lacom/Aon_2018_Trends_In_Global_E mployee_Engagement.pdf

[Hozzáférés dátuma: 2611 2019].

Asztalos, M. és mtsai., 2012. Sport participation and stress among women and men. Psychology of Sport and Exercise, 13(4), pp. 466-483.

Babrovich, N., 2017. How to use gamification in banking to engage customers and employees. [Online]

Available at: https://www.scnsoft.com/blog/gamification-in-banking

[Hozzáférés dátuma: 81 2020].

Baksa-Haskó, G., 2017. Efficiency Over 1000 Students - The Evolution of an On-line Course: From e-Learning to Flipped Classroom. Interactive Collaborative Learning: Proceedings of the 19th ICL Conference, pp. 237-245.

Barna, B., 2016. Gamification in Education. SEFBIS Journal, 10(1), pp. 66-74.

Barna, B. \& Fodor, S., 2015. Gamification és közgazdászképzés - Játszani is enged?. DIBIZ: Digital Business, 1(4), pp. 34-36.

Barna, B. \& Fodor, S., 2018a. An Empirical Study on the Use of Gamification on IT Courses at Higher Education. Teaching and Learning in a Digital World. ICL 2017. Advances in Intelligent Systems and Computing, 715. kötet, pp. 684-692.

Barna, B. \& Fodor, S., 2018b. Gamifikált közösségi megoldás használata a kedvezőbb munkahelyi légkör kialakítása érdekében. Vezetéstudomány - Budapest Management Review, 49(3), pp. 2-10.

Barna, B. \& Fodor, S., 2018c. Gamification's Impact on Employee Engagement: Enhancing Employee Well-Being with a Cloud Based Gamified Team-Building Application. 2018 6th International Conference on Future Internet of Things and Cloud Workshops (FiCloudW), pp. 203-208.

Barna, B. \& Fodor, S., 2018d. Categorisation of employees based on their usage of an online team-building application. Poszter.. OGIK 2018, november 9-10.: Sopron.

Barna, B. \& Fodor, S., 2019a. Complex Gamification Platform Based On Moodle System. Proceedings of the 16th International Conference on Cognition and Exploratory Learning in the Digital Age (CELDA 2019), pp. 409-412. 
Barna, B. \& Fodor, S., 2019b. A Data-Driven Approach to Analyze User Behavior on a Personalized Gamification Platform. GALA 2019. Lecture Notes in Computer Science, 11899. kötet, pp. 266-275.

Barna, B., Omiya, T. \& Kadobayashi, Y., 2019. Gamification in Education: Designing and Implementing a Gamified Educational On-line Tool. SEFBIS Journal, 13(1), pp. 84-90.

Bartle, R., 1993. Hearts, clubs, diamonds, spades: Players who suit MUDs. Journal of MUD research, 1(1), p. 13.

Bartle, R. A., 2003. A Self of Sense. hely nélk.: SELFWARE.games.

Battlejungle Support, 2016. Battlejungle levels - Levels to be reached. [Online] Available at: http://support.battlejungle.com/knowledge-base/battlejunglelevels/\#levels-to-be-reached

[Hozzáférés dátuma: 3011 2019].

Battlejungle, 2019. Battlejungle. [Online]

Available at: https://battlejungle.com/

[Hozzáférés dátuma: 2911 2019].

Bíró, G. I., 2014. Didactics 2.0: A Pedagogical Analysis of Gamification Theory from a Comparative Perspective with a Special View to the Components of Learning.. Procedia - Social and Behavioral Sciences, 25 8, 141. kötet, pp. 148-151.

Blohm, I. \& Leimeister, J. M., 2013. Gamification Design of IT-Based Enhancing Services for Motivational Support and Behavioral Change. Business \& Information Systems Engineering, Június, 5(4), pp. 275-278.

Bogost, I., 2013. Exploitationware. In: R. Colby, M. S. S. Johnson \& R. S. Colby, szerk. Rhetoric/Composition/Play through Video Games. New York: Palgrave Macmillan, pp. Bogost, I. (2013). Exploitationware. Rhetoric/Composition/Play through Video Games, 139-147. doi:10.1057/9781137307675_11 .

Bonk, C. J. \& Graham, C. R., 2006. The Handbook of Blended Learning: Global Perspectives, Local Designs. New York: Pfeiffer.

BrainHexBlog, 2008. BrainHex. [Online] Available at: https://blog.brainhex.com/

[Hozzáférés dátuma: 1408 2020].

Briggs Myers, I., McCaulley, M. H. \& Most, R., 1985. Manual, a guide to the development and use of the Myers-Briggs type indicator. Palo Alto: California Consulting Psychologists Press.

Brignull, H. \& Burns, H., 2014. 90 Percent of Everything. [Online]

Available at: https://90percentofeverything.com/2014/08/26/some-dark-patterns-nowillegal-in-uk-interview-with-heather-burns/index.html

[Hozzáférés dátuma: 1608 2020].

Brignull, H., dátum nélk. Dark Patterns. [Online]

Available at: https://darkpatterns.org/types-of-dark-pattern.html

[Hozzáférés dátuma: 1608 2020]. 
Bunchball, 2010. Gamification 101: An Introduction to the Use of Game Dynamics to Influence Behavior. [Online]

Available at: http://jndglobal.com/wp-content/uploads/2011/05/gamification1011.pdf [Hozzáférés dátuma: 2111 2019].

Busch, M. és mtsai., 2016. Using player type models for personalized game design - An empirical investigation. IxD\&A, 28. kötet, pp. 145-163.

Busch, M. és mtsai., 2016. Player Type Models - Towards Empirical Validation. Proceedings of the 2016 CHI Conference Extended Abstracts on Human Factors in Computing Systems - CHI EA '16., pp. 1835-1841.

Cameron, J., Banko, K. M. \& Pierce, W. D., 2001. Pervasive negative effects of rewards on intrinsic motivation: The myth continues.. The Behavior Analyst, 24(1), pp. 1-44.

Centrical, dátum nélk. Sykes speeds-up onboarding without compromising on competency. [Online]

Available at: https://centrical.com/case-studies/sykes-onboarding/

[Hozzáférés dátuma: 91 2020].

Chou, Y.-k., 2013. The 10 best examples of using Gamification in the enterprise, corporate workplace. [Online]

Available at: https://yukaichou.com/gamification-examples/top-10-enterprisegamification-cases-employees-productive/\#.WvH191SpnyU

[Hozzáférés dátuma: 91 2020].

Chou, Y.-k., 2013. The Six Contextual Types of Rewards in Gamification. [Online] Available at: https://yukaichou.com/marketing-gamification/six-context-typesrewards-gamification/

[Hozzáférés dátuma: 612 2019].

Chou, Y.-k., dátum nélk. The 10 Best Productivity Apps that use Gamification in 2019. [Online]

Available at: https://yukaichou.com/lifestyle-gamification/the-top-ten-gamifiedproductivity-apps/

[Hozzáférés dátuma: 81 2020].

Cialdini, R. B. \& Goldstein, N. J., 2002. The science and practice of persuasion. The Cornell Hotel and Restaurant Administration Quarterly, 43(2), p. 40-50.

Clark, T., 2011. The Gamification of SAP. [Online] Available at: https://www.forbes.com/sites/sap/2011/03/04/the-gamification-ofsap/\#3e51923835ed

[Hozzáférés dátuma: 2711 2019].

Csíkszentmihályi, M., 2001. Flow - Az áramlat. A tökéletes élmény pszichológiája. Budapest: Akadémia Kiadó.

Deci, E. L., 1971. The Effects of Externally Mediated Rewards on Intrinsic Motivation. Journal of Personality and Social Psychology, 18(1), pp. 105-115.

Deci, E. L., 1972. Intrinsic motivation, extrinsic reinforcement, and inequity. Journal of Personality and Social Psychology, 22(1), pp. 113-120.

Deci, E. L. \& Ryan, R. M., 2004. Handbook of Self-Determination Research. 1 szerk. Rochester: NY: University of Rochester Press. 
Denny, P., 2013. The effect of virtual achievements on student engagement.

Proceedings of the SIGCHI Conference on Human Factors in Computing Systems, pp. 763-772.

Deterding, S., Dixon, D., Khaled, R. \& Nacke, L., 2011. From Game Design Elements to Gamefulness: Defining "Gamification". p. 1..

DGA, 2017. Applied games and gamification. [Online]

Available at: https://dutchgamesassociation.nl/applied/applied-games-gamification/

[Hozzáférés dátuma: 233 2020].

Dixon, D., 2011. Player Types and Gamification. Proceedings of the CHI 2011

Workshop on Gamification, 5.

Dodds, J., 2015. 4 Alternative Terms For Gamification. [Online]

Available at: https://engageforsuccess.org/4-alternative-terms-for-gamification

[Hozzáférés dátuma: 233 2020].

Dolan, E. G., 1971. Alienation, Freedom, and Economic Organization. Journal of Political Economy, 79(5), p. 1084-1094.

Domínguez, A. és mtsai., 2013. Gamifying learning experiences: Practical implications. Computers \& Education, 63. kötet, pp. 380-392.

Dornisch, J., 2020. How Do You Know When You're Being Manipulated? The Dangers of Dark Pattern Design. [Online]

Available at: https://www.brinknews.com/how-do-you-know-when-youre-beingmanipulated-the-dangers-of-dark-design/

[Hozzáférés dátuma: 1608 2020].

Droga5, 2011. Case Study: Bing - Decode Jay-Z. [Online]

Available at: https://vimeo.com/54006986

[Hozzáférés dátuma: 1012 2019].

eNet, 2018. Magyarország 3,7 millió játékos hazája. [Online]

Available at: https://enet.hu/hirek/magyarorszag-37-millio-jatekos-hazaja/

[Hozzáférés dátuma: 2712 2019].

ESA, 2016. 2016 Essential Facts about the Computer and Video Game Industry.

[Online]

Available at: http://essentialfacts.theesa.com/Essential-

[Hozzáférés dátuma: 3010 2017].

ESA, 2019. 2019 Essential Facts about the Computer and Video Game Industry.

[Online]

Available at: https://www.theesa.com/wp-content/uploads/2019/05/2019-Essential-

Facts-About-the-Computer-and-Video-Game-Industry.pdf

[Hozzáférés dátuma: 2711 2019].

Eyal, N., 2014. Hooked: A Guide to Building Habit-Forming Products. 1. kiadás szerk. USA: Portfolio / Penguin.

Farkas, F., Jarjabka, Á., Lóránd, B. \& Bálint, B., 2013. Munkahelyi motivációk

Magyarországon 2013-ban. Vezetéstudomány, 44(10), pp. 12-23. 
Farzan, R. és mtsai., 2008. Results from deploying a participation incentive mechanism within the enterprise. Firenze, Olaszország, CHI 2008, pp. 563-572.

Ferrara, J., 2012. Playful Design: Creating Game Experiences in Everyday Interfaces. New York: Rosenfeld Media.

Fodor, S. \& Barna, B., 2020. An empirical study on factors affecting user engagement in a gamified team building environment. International Journal of Serious Games, $p$. (under revision).

Fogg, B. J., 2009. A Behavior Model for Persuasive Design. Persuasive '09:

Proceedings of the 4th International Conference on Persuasive Technology, 40. kötet, pp. 1-7.

Fromann, R., 2012. Gamification - Épülőben a Homo Ludens társadalma?.

Fromann, R., 2018a. JátékosLét 2017 Kérdőív eredmények 1. rész Demográfiai adatok. [Online]

Available at:

http://jatekoslet.hu/letoltes/2017/jatekoslet_kerdoiv_2017_1_demografiai_adatok.pdf [Hozzáférés dátuma: 2812 2019].

Fromann, R., 2018b. JátékosLét 2017 Kérdőív eredmények 2. rész Játékhasználati szokások. [Online]

Available at:

http://jatekoslet.hu/letoltes/2017/jatekoslet_kerdoiv_2017_2_jatekhasznalat.pdf [Hozzáférés dátuma: 2812 2019].

Fromann, R., 2018c. JátékosLét 2017 Kérdőív eredmények 3. rész Játékosok motivációi. [Online]

Available at:

http://jatekoslet.hu/letoltes/2017/jatekoslet_kerdoiv_2017_3_motivacio.pdf [Hozzáférés dátuma: 2812 2019].

Giuffre, K., 2015. Cultural Production in Networks. International Encyclopedia of the Social and Behavioral Sciences, pp. 466-470.

Goehle, G., 2013. Gamification and web-based homework. PRIMUS: problems, resources, and issues in mathematics undergraduate studies, 23(3), pp. 234-246.

Goldberg, L. R., 1993. The structure of phenotypic personality traits. American Psychologist, 48(1), pp. 26-34.

Grace, M. V. \& Hall, J., 2008. Projecting Surveillance Entertainment. San Diego, CA: ETech.

Grant, S. \& Betts, B., 2013. Encouraging user behaviour with achievements: an empirical study. Mining Software Repositories (MSR), 2013 10th IEEE Working Conference, pp. 65-68.

Gray, C. M. és mtsai., 2018. The Dark (Patterns) Side of UX Design. Proceedings of the 2018 CHI Conference on Human Factors in Computing Systems.

Haaranen, L., Ihantola, P., Hakulinen, L. \& Korhonen, A., 2014. How (not) to Introduce Badges to Online Exercises. Proceedings of the 45th ACM Technical Symposium on Computer Science Education - SIGCSE, pp. 33-38. 
Hamari, J. \& Lehdonvirta, V., 2010. Game design as marketing: How game mechanics create demand for virtual goods. International Journal of Business Science and Applied Management, 5(1), pp. 14-29.

Hamari, J. \& Tuunanen, J., 2014. Player Types: A Meta-synthesis. Transactions of the Digital Games Research Association, 1(2), pp. 29-53.

Harter, J. K., Schmidt, F. L. \& Hayes, T. L., 2002. Business-Unit-Level Relationship Between Employee Satisfaction, Employee Engagement, and Business Outcomes: A Meta-Analysis. Journal of Applied Psychology, 87(2), pp. 268-279.

Hassan, L., Dias, A. \& Hamari, J., 2019. How motivational feedback increases user's benefits and continued use: A study on gamification, quantified-self and social networking. International Journal of Information Management, 46. kötet, pp. 151-162.

Horovitz, B., 2012. After Gen X, Millennials, what should next generation be?. [Online] Available at: http://usatoday30.usatoday.com/money/advertising/story/2012-0503/naming-the-next-generation/54737518/1

[Hozzáférés dátuma: 2511 2019].

Houtman, I., Jettinghoff, K. \& Cedillo, L., 2007. Raising awareness of stress at work in developing countries. Protecting workers' health series, 6. kötet.

Hunicke, R., LeBlanc, M. \& Zubek, R., 2004. MDA: A Formal Approach to Game Design and Game Research. 19th National Conference on Artificial Intelligence.

Huotari, K. \& Hamari, J., 2012. Defining Gamification - A Service Marketing Perspective. Proceedings of the 16th International Academic MindTrek, pp. 17-22.

Jackson, M., 2016. Gamification in Education: A Literature Review. [Online] Available at: http://www.westpoint.edu/cfe/Literature/MJackson_16.pdf [Hozzáférés dátuma: 77 2017].

James, W., 1890. The Principles of Psychology. 1. kiadás szerk. New York: Henry Holt and Company.

Jobbágy, M. \& Takács, P., 1997. Az a közös bennünk, hogy mások vagyunk. Iskolakultúra, 7(6), pp. 78-93.

Jung, C. G., 2006. A lélektani típusok. Budapest: Európa.

Jurgelaitis, M., Drungilas, V. \& Čeopniené, L., 2018. Gamified Moodle Course for Teaching UML. Baltic J. Modern Computing, 6(2), pp. 119-127.

Kapp, K. M., 2012. The Gamification of Learning and Instruction: Game-based Methods and Strategies for Training and Eduction. 1. kiadás szerk. San Francisco: Pfeiffer.

Keller, K. L. \& Kotler, P., 2008. Marketingmenedzsment. hely nélk.:Akadémiai Kiadó Zrt..

Kenéz, A., 2015. Gamification - a játékok alkalmazása a marketingben és a marketingoktatásban. Marketing \& Menedzsment, 2015(4), pp. 36-50.

Kiss, K. \& András, K., 2018. A sport mint szabadidős- és életminőség-tényező Budapest IX. kerületének példája alapján. "Sport - Gazdaság - Turizmus" Kautz Gyula Emlékkonferencia. 
Koivisto, J. \& Hamari, J., 2014. Demographic differences in perceived benefits from gamification. Computers in Human Behavior, 35(1), pp. 179-188.

Koster, R., 2013. A Theory of Fun for Game Design. 2. kiadás szerk. Cambridge: O'Reilly Media.

Krueger, D. \& Kumar, K. B., 2004. Skill-Specific rather than General Education: A Reason for US-Europe Growth Differences?. Journal of Economic Growth, 9(2), p. 167-207.

Kuo, I., 2013. Why It Doesn't Matter What "Gamification" Is Called. [Online] Available at: https://www.gamification.co/2013/05/03/why-it-doesnt-matter-whatgamification-is-called/

[Hozzáférés dátuma: 233 2020].

Lavoué, E., Monterrat, B., Desmarais, M. \& George, S., 2018. Adaptive Gamification for Learning Environments. IEEE Transactions on Learning Technologies, 12(1), pp. 16-28.

Li, C., Dong, Z., Untch, R. H. \& Chasteen, M., 2013. Engaging Computer Science Students through Gamification in an Online Social Network Based Collaborative Learning Environment. International Journal of Information and Education Technology, 3(1), pp. 72-77.

Limayem, M., Hirt, S. G. \& Cheung, C. M. K., 2007. How Habit Limits the Predictive Power of Intention: The Case of Information Systems Continuance. MIS Quarterly, 31(4), pp. 705-737.

Lister, M., 2015. Gamification: The effect on student motivation and performance at the post-secondary level. Issues and Trends in Educational Technology, 3(2), pp. 1-22.

Liszewski, A., 2010. The Speed Camera Lottery Adds Positive Reinforcement To Encourage People To Obey The Speed Limit. [Online] Available at: https://www.ohgizmo.com/the-speed-camera-lottery-adds-positivereinforcement-to-encourage-people-to-obey-the-speed-limit/ [Hozzáférés dátuma: 163 2020].

Lynch, M., 2017. 8 must have gamification apps, tools, and resources. [Online] Available at: https://www.thetechedvocate.org/8-must-gamification-apps-toolsresources/

[Hozzáférés dátuma: 3112 2019].

Marache-Francisco, C. \& Brangier, E., 2013. Process of Gamification. From The Consideration of Gamification To Its Practical Implementation. CENTRIC 2013 : The Sixth International Conference on Advances in Human-oriented and Personalized Mechanisms, Technologies, and Services, pp. 126-131.

Marczewski, A., 2013. The Intrinsic Motivation RAMP. [Online] Available at: https://www.gamified.uk/gamification-framework/the-intrinsicmotivation-ramp/

[Hozzáférés dátuma: 114 2020].

Marczewski, A., 2017. 52 Gamification Mechanics and Elements. [Online] Available at: https://www.gamified.uk/user-types/gamification-mechanics-elements/ [Hozzáférés dátuma: 612 2019]. 
Markets and Markets, 2016. Gamification Market by Solution (Consumer driven and Enterprise driven), Applications (Sales and Marketing), Deployment Type (OnPremises and Cloud), User Type (Large Enterprise, SMBs), Industry and Region Global Forecast to 2020. [Online]

Available at: https://www.marketsandmarkets.com/Market-Reports/gamificationmarket-991.html

[Hozzáférés dátuma: 2411 2019].

Markets and Markets, 2019. Gamification in Education Market by Offering (Software and Services), Deployment Mode (Cloud and On-Premises), End User (Academic (K12 and Higher Education) and Corporate Training (SMEs and Large Enterprises)), and Region - Global Forecast to 2023. [Online]

Available at: https://www.marketsandmarkets.com/Market-Reports/gamificationeducation-market-10910763.html

[Hozzáférés dátuma: 0201 2020].

Mathe, H., Pavie, X. \& O'Keeffe, M., 2011. Valuing People to Create Value: An Innovative Approach to Leveraging Motivation at Work. Szingapúr: World Scientific Publishing Company.

Mathur, A. és mtsai., 2019. Dark Patterns at Scale: Findings from a Crawl of 11K Shopping Websites. Proceedings of the ACM on Human-Computer Interaction, 3. kötet, pp. 81:1-81:32.

McDonald, M., Musson, R. \& Smith, R., 2008. Using Productivity Games to Prevent Defects. In: The Practical Guide to Defect Prevention. Redmond: Microsoft Press, pp. 79-95.

McGonigal, J., 2011. Reality Is Broken, Why Games Make Us Better and How They Can Change the World. New York: The Penguin Press.

Mekler, E. D., Brühlmann, F., Opwis, K. \& Tuch, A. N., 2013. Disassembling gamification: The effects of points and meaning on user motivation and performance. Párizs, Franciaország, CHI 2013, pp. 1137-1142.

Mérő, L., 2010. Az érzelmek logikája. hely nélk.:Tericum Kiadó.

Mészáros, A., 2014. Személyiségpreferenciák az oktatásban. Szaknyelv és szakfordítás. Tanulmányok a szakfordítás és a fordítóképzés aktuális témáiról., pp. 64-71.

Meyer, D. K. \& Turner, J. C., 2006. Re-conceptualizing emotion and motivation to learn in classroom context. Educational Psychology Review, 18(4), pp. 377-390.

Moodle, 2015. Tanári kézikönyv MOODLE e-oktatási keretrendszer használatához. [Online]

Available at: https://docplayer.hu/2730527-Tanari-kezikonyv-moodle-e-oktatasikeretrendszer-hasznalatahoz.html

[Hozzáférés dátuma: 2712 2019].

Moodle, 2019. Gamification - A list of plugins that brings some aspects of gamification to Moodle courses.. [Online]

Available at: https://moodle.org/plugins/browse.php?list=set\&id=88

[Hozzáférés dátuma: 0312 2019]. 
Morrison, B. B. \& DiSalvo, B., 2014. Khan academy gamifies computer science. SIGCSE '14 Proceedings of the 45th ACM technical symposium on Computer science education, pp. 39-44.

Morsella, E., Bargh, J. A. \& Gollwitzer, P. M., 2008. Social cognition and social neuroscience. Oxford handbook of human action.. 1. kiadás szerk. New York: Oxford University Press..

Nacke, L., Bateman, C. \& Mandryk, R. L., 2011. BrainHex: preliminary results from a neurobiological gamer typology survey. Proceedings of Entertainment Computing ICEC 2011: 10th International Conference, Vancouver, Kanada, Springer.

Nacke, L. E., Bateman, C. \& Mandryk, R. L., 2014. BrainHex: A neurobiological gamer typology survey. Entertainment Computing, 5(1), pp. 55-62.

Nicholson, S., 2012. A User Centered Theoretical Framework for Meaningful Gamification. Games+Learning+Society 8.0, pp. 1-7.

Nicholson, S., 2014. A RECIPE for Meaningful Gamification. In: T. Reiners \& L. C. Wood, szerk. Gamification in Education and Business. Switzerland: Springer, Cham, p. 1-20.

Niman, N. B., 2014. The Gamification of Higher Education. Developing a Game-Based Business Strategy in a Disrupted Marketplace. 1. kiadás szerk. New York: Palgrave Macmillan.

O'Donovan, S., Gain, J. \& Marais, P., 2013. A case study in the gamification of a university-level games development course. SAICSIT '13 Proceedings of the South African Institute for Computer Scientists and Information Technologists Conference, pp. 242-251.

Oehler, K. \& Adair, C., 2019. 2019 Trends in Global Employee Engagement. [Online] Available at: https://www.kincentric.com//media/kincentric/pdfs/kincentric_2019_trends_global_employee_engagement.pdf [Hozzáférés dátuma: 2611 2019].

Oliveira, W., Bittencourt, I. I. \& Vassileva, J., 2017. Tailoring gamified virtual learning environments based on gamer types. Master Thesis.. Maceió: Federal University of Alagoas, Computer Science Institute, Postgraduate Program of Computer Science.

Omiya, T., Barna, B. \& Kadobayashi, Y., 2019. WebSec: Development and Evaluation of game exercise tool for security training. IEICE Technical Report Educational Technology, 118(427), pp. 13-18.

Orji, R., Mandryk, R. L. \& Vassileva, J., 2017. Improving The Efficacy Of Games for Change Using Personalization Models. ACM Transactions on Computer-Human Interaction, 24(5), pp. 1-22.

Orji, R., Vassileva, J. \& Mandryk, R. L., 2013. LunchTime: a slow-casual game for long-term dietary behavior change. Personal and Ubiquitous Computing, 17(6), pp. 1211-1221.

Pacsi, D. \& Szabó, Z., 2017. A Gamifikáció Fejlődése és a Magyar Gamifikációs Trend Alakulása. Studia Mundi - Economica, 4(1), pp. 57-68. 
Pastor-Pina, H. és mtsai., 2015. Can Moodle be used for structural gamification?. INTED2015 Proceedings, pp. 1014-1021.

Perrin, T., 2008. Closing The Engagement Gap: A Road Map for Driving Superior Business Performance. [Online]

Available at: https://c.ymcdn.com/sites/simnet.site-

ym.com/resource/group/066D79D1-E2A8-4AB5-B621-

60E58640FF7B/leadership_workshop_2010/towers_perrin_global_workfor.pdf [Hozzáférés dátuma: 2611 2019].

Portfólió, 2019. Közel 4 millió magyar játszik videójátékokkal. [Online]

Available at: https://www.portfolio.hu/uzlet/20190122/kozel-4-millio-magyar-jatszikvideojatekokkal-311267

[Hozzáférés dátuma: 2812 2019].

Priebatsch, S., 2010. The Game Layer on Top of the World. Boston: TEDx.

Pusztai, Á., 2018. Gyakorlati játékosítás - Hogyan teremtsünk játékosított ügyfélélményt?. 1. kiadás szerk. OOK Press, Veszprém: Kollektíva (Pann-túra Szövetkezet).

Rab, Á. S., 2012. Rab Árpád: A gamifikáció lehetőségei a nem üzleti célú felhasználások területén, különös tekintettel a közép-és felsőoktatásra. [Online] Available at: http://www.oktatas-informatika.hu/2013/03/rab-arpad-a-gamifikaciolehetosegei-a-nem-uzleti-celu-felhasznalasok-teruleten-kulonos-tekintettel-a-kozep-esfelsooktatasra/

[Hozzáférés dátuma: 1608 2020].

Rab, Á. S., 2015. A digitális kultúra hatása az emberi viselkedésre a gamifikáció példáján keresztül. Doktori értekezés.. Budapest: Budapesti Corvinus Egyetem Szociológia Doktori Iskola.

Raftopoulos, M., Walz, S. \& Greuter, S., 2015. How enterprises play: Towards a taxonomy for enterprise gamification. Luneburg, Germany, DiGRA 2015 Conference.

Robertson, M., 2010. Can't play, won't play. [Online]

Available at: https://kotaku.com/cant-play-wont-play-5686393

[Hozzáférés dátuma: 3112 2019].

Robson, K. és mtsai., 2015. Game on: Engaging customers and employees through gamification. Business Horizons, 59(1), pp. 29-36.

Ryan, R. M. \& Deci, E. L., 2000. Self-Determination Theory and the Facilitation of Intrinsic Motivation, Social Development, and Well-Being. American Psychologist, 55(1), pp. 68-78.

Sailer, M., Hense, J., Mandl, H. \& Klevers, M., 2013. Psychological Perspectives on Motivation through Gamification. Interaction Design and Architecture(s) Journal IxD\&A, 19. kötet, pp. 28-37.

Salen, K. \& Eric, Z., 2003. Rules of Play: Game Design Fundamentals. 1st szerk. hely nélk.:The MIT Press.

Scarbrough, H. és mtsai., 2014. Health Services and Delivery Research. Networked innovation in the health sector: comparative qualitative study of the role of 
Collaborations for Leadership in Applied Health Research and Care in translating research into practice.. Southampton, United Kingdom: NIHR Journals Library.

Schaufeli, W. B., 2012. Work Engagement. What Do We Know and Where Do We Go? Work Engagement in Everyday Life, Business, and Academia.. Romanian Journal of Applied Psychology, 14. kötet, pp. 3-10.

Schunk, D. H., Pintrich, P. R. \& Meece, J. L., 2008. Motivation in education: theory, research and applications. 4. szerk. Merrill: Prentice Hall International.

Schunk, D. H. \& Usher, E. H., 2012. Social Cognitive Theory and Motivation. In: The Oxford Handbook of Human Motivation. Oxford: Oxford University Press.

Scratch, dátum nélk. Scratch oktatóknak. [Online]

Available at: https://scratch.mit.edu/educators

[Hozzáférés dátuma: 21 2020].

Sharp, B. \& Dawes, J., 2001. What is Differentiation and How Does it Work?. Journal of Marketing Management, 17(7), pp. 739-759.

Shuck, B. \& Rose, K., 2013. Reframing Employee Engagement Within the Context of Meaning and Purpose Implications for HRD. Advances in Developing Human Resources, 15(4), pp. 341-355.

Shuck, B. \& Wollard, K., 2010. Employee Engagement and HRD: A Seminal Review of the Foundations. Human Resource Development Review, 9(1), pp. 89-110.

Sorenson, S. \& Garman, K., 2013. State of the American Workplace. Employee Engagement Insights for U.S. Business Leaders. [Online]

Available at: https://news.gallup.com/businessjournal/162953/tack-le-employeesstagnating-engagement.aspx

[Hozzáférés dátuma: 2611 2019].

Szabó, A., 2016. A munkavállalói elkötelezettség növelésének hatása és lehetőségei. Opus et Educatio, 3(4), pp. 439-450.

Takahashi, D., 2008. Funware's threat to the traditional video game industry. [Online] Available at: https://venturebeat.com/2008/05/09/funwares-threat-to-the-traditionalvideo-game-industry/

[Hozzáférés dátuma: 233 2020].

Taylor, B. C., Sallis, J. F. \& Needle, R., 1985. The relation of physical activity and exercise to mental health. Public Health Reports, 100(2), pp. 195-202.

Toda, A. M. és mtsai., 2019. Analysing gamification elements in educational environments using an existing Gamification taxonomy. Smart Learning Environments, 6(16), pp. 1-14.

Tran, V.-D. \& Huynh, N. D. T., 2015. Exploring the relationships among social benefits, online social network dependency, satisfaction, and youth's habit formation. International Journal of Cyber Society and Education, 8(2), pp. 99-114.

Uzzi, B. \& Spiro, J., 2005. Collaboration and creativity: The small world problem. American journal of sociology, 111(2), pp. 447-504. 
Verplanken, B. \& Aarts, H., 2011. Habit, Attitude, and Planned Behaviour: Is Habit an Empty Construct or an Interesting Case of Automaticity?. European Review of Social Psychology, 10(1), pp. 101-134.

Watts, M. \& Schaur, G., 2011. Teaching and Assessment Methods in Undergraduate Economics: A Fourth National Quinquennial Survey. The Journal of Economic Education, 42(3), p. 294-309.

Werbach, K. \& Hunter, D., 2012. For The Win. How Game Thinking Can Revolutionize Your Business. hely nélk.:Wharton Digital Press.

Werbach, K., dátum nélk. Coursera: Gamification course. [Online] Available at: https://www.coursera.org/learn/gamification [Hozzáférés dátuma: 1112020$].$

Yee, N., 2006. The Demographics, Motivations, and Derived Experiences of Users of Massively Multi-User Online Graphical Environments. Presence Teleoperators \& Virtual Environments, 15(3), pp. 309-329.

Zichermann, G. \& Cunningham, C., 2011. Gamification by Design: Implementing Game Mechanics in Web and Mobile Apps. Sebastopol, Canada: O'Reilly Media Inc.. 


\section{TÉZIS ALAPJÁT SZOLGÁLÓ SAJÁT PUBLIKÁCIÓK}

\section{Referált szakmai folyóiratban megjelent tanulmányok}

Fodor, S. \& Barna, B., 2020. An empirical study on factors affecting user engagement in a gamified team building environment. International Journal of Serious Games (elfogadott kézirat).

Barna, B., Omiya, T. \& Kadobayashi, Y. (2019). Gamification in Education: Designing and Implementing a Gamified Educational On-line Tool. SEFBIS Journal, 13(1), pp. 84-90.

Barna, B. \& Fodor, S. (2019b). A Data-Driven Approach to Analyze User Behavior on a Personalized Gamification Platform. Lecture Notes in Computer Science, 11899. kötet, pp. 266-275.

Barna, B. \& Fodor, S. (2018b). Gamifikált közösségi megoldás használata a kedvezőbb munkahelyi légkör kialakítása érdekében. Vezetéstudomány - Budapest Management Review, 49(3), pp. 2-10. [Kiváló Cikk 2018 díj]

Barna, B. \& Fodor, S. (2018a). An Empirical Study on the Use of Gamification on IT Courses at Higher Education. Advances in Intelligent Systems and Computing, 715. kötet, pp. 684-692.

Barna, B. (2016). Gamification in Education. SEFBIS Journal, 10(1), pp. 66-74.

\section{Lektorált konferenciakötetben megjelent tanulmányok}

Omiya, T., Barna, B. \& Kadobayashi, Y. (2019). WebSec: Development and Evaluation of game exercise tool for security training. IEICE Technical Report Educational Technology, 118(427), pp. 13-18.

Barna, B. \& Fodor, S. (2019a). Complex Gamification Platform Based On Moodle System. Proceedings of the 16th International Conference on Cognition and Exploratory Learning in the Digital Age (CELDA 2019), pp. 409-412.

Barna, B. \& Fodor, S. (2018c). Gamification's Impact on Employee Engagement: Enhancing Employee Well-Being with a Cloud Based Gamified Team-Building Application. 2018 6th International Conference on Future Internet of Things and Cloud Workshops (FiCloudW), pp. 203-208. 


\section{Egyéb szakmai publikációk}

Barna, B. \& Fodor, S. (2019). Complex Gamification Platform Based On Moodle System. 16th International Conference on Cognition and Exploratory Learning in Digital Age (CELDA 2019) 2019. november 7., Cagliari, Olaszország [kivonat]

Barna, B. (2019a): Felügyelet nélküli gamifikált oktatói platform létrehozása és hatásának vizsgálata. ÚNKP konferencia 2019. április 29., Budapest [poszter]

Barna, B. \& Fodor, S. (2018). Categorisation of employees based on their usage of an online team-building application. 15. Országos Gazdaságinformatikai Konferencia, OGIK 2018. november 9-10., Sopron [poszter, kivonat] [Legjobb poszterelőadás és bemutató díj]

Barna, B. \& Fodor, S. (2017). Battlejungle, an online platform for using enterprise gamification to engage employees. 14. Országos Gazdaságinformatikai Konferencia, OGIK 2017. november 10-11., Sopron [kivonat]

Barna, B. \& Fodor, S. (2015). Gamification és közgazdászképzés - Játszani is enged?. DIBIZ: Digital Business, 1(4), pp. 34-36.

Barna, B. (2014). Gamification in Education. 11. Országos Gazdaságinformatikai Konferencia, OGIK 2014. november 7-8., Budapest [kivonat] 


\section{MELLÉKLETEK}

\section{Melléklet: Visszajelzési kérdések}

\begin{tabular}{|c|c|c|c|}
\hline Kérdés & Válasz & Kategória & Megjegyzés \\
\hline $\begin{array}{l}\text { Hogyan változott a szerveze- } \\
\text { ténél a légkör a szolgáltatás } \\
\text { bevezetése óta? } \\
\text { Hogyan változott a szerveze- } \\
\text { ténél a légkör az elmúlt } 30 \\
\text { napban? }\end{array}$ & $\begin{array}{l}\text { 1) Kellemetlenné vált; } \\
\text { 2) Kicsit rosszabb } \\
\text { 3) Ugyanolyan } \\
\text { 4) Kicsit jobb } \\
\text { 5) Barátságosabb és ke- } \\
\text { vésbé stresszes }\end{array}$ & $\begin{array}{l}\text { Munkahe- } \\
\text { lyi légkör } \\
\text { változása }\end{array}$ & \multirow{3}{*}{$\begin{array}{l}\text { Általános, pozí- } \\
\text { ció szerint nem } \\
\text { korlátozott meg- } \\
\text { jelenésü. }\end{array}$} \\
\hline $\begin{array}{l}\text { Hány egyáltalán nem vagy } \\
\text { kevésbé ismert emberrel is- } \\
\text { merkedett meg a Battle- } \\
\text { jungle-ön keresztül az elmúlt } \\
30 \text { napban? }\end{array}$ & $\begin{array}{l}\text { 1) } 0 \\
\text { 2) } 1-2 \\
\text { 3) } 3-5 \\
\text { 4) } 6-9 \\
\text { 5) } 10+ \\
\end{array}$ & \multirow{2}{*}{$\begin{array}{l}\text { A szerve- } \\
\text { zeti tagjai- } \\
\text { val történő } \\
\text { kapcsolatok } \\
\text { száma és } \\
\text { minősége }\end{array}$} & \\
\hline $\begin{array}{l}\text { Jobb-e a kapcsolata azokkal } \\
\text { az emberekkel, akikkel már } \\
\text { játszott együtt? }\end{array}$ & $\begin{array}{l}\text { 1) Nem, sokkal rosszabb! } \\
\text { 2) Nem, kicsit rosszabb } \\
\text { 3) Változatlan } \\
\text { 4) Igen, kicsit jobb } \\
\text { 5) Igen, sokkal jobb! }\end{array}$ & & \\
\hline $\begin{array}{l}\text { Többet sportol a szolgáltatás } \\
\text { használata óta? }\end{array}$ & $\begin{array}{l}\text { 1) Nem, sokkal kevesebbet! } \\
\text { 2) Nem, kicsivel keveseb- } \\
\text { bet. } \\
\text { 3) Változatlan } \\
\text { 4) Igen, kicsivel többet } \\
\text { 5) Igen, sokkal többet! }\end{array}$ & \multirow[b]{2}{*}{$\begin{array}{l}\text { Sportolások } \\
\text { gyakori- } \\
\text { sága }\end{array}$} & $\begin{array}{l}\text { A belső rendszer } \\
\text { föoldalán jele- } \\
\text { nik meg. }\end{array}$ \\
\hline $\begin{array}{l}\text { Előfordult-e már, hogy [adott } \\
\text { sportból] többet űzött csak } \\
\text { azért, hogy a szolgáltatásban } \\
\text { rögzítse az eredményét? }\end{array}$ & $\begin{array}{l}\text { 1) Nem, még az érdeklödé- } \\
\text { semet is elvesztettem } \\
\text { 2) Nem, még egy kicsit rit- } \\
\text { kábban is teszem } \\
\text { 3) Csak a megszokott ren- } \\
\text { demet jelentem be } \\
\text { 4) Igen, néhány alkalommal } \\
\text { 5) Igen, többször is, inspirál } \\
\text { engem }\end{array}$ & & $\begin{array}{l}\text { Az [adott } \\
\text { sportú] bajnok- } \\
\text { ság oldalán ke- } \\
\text { rül feltevésre. }\end{array}$ \\
\hline $\begin{array}{l}\text { Mennyire volt szórakoztató a } \\
\text { meccs? }\end{array}$ & $\begin{array}{l}\text { 1) Nem tetszett. } \\
\text { 2) Nem volt olyan jó } \\
\text { 3) Semleges } \\
\text { 4) Egész jó volt } \\
\text { 5) Fantasztikus volt! }\end{array}$ & $\begin{array}{l}\text { Eredmény- } \\
\text { bejelentés } \\
\text { utáni érzése }\end{array}$ & $\begin{array}{l}\text { Meccsalapú baj- } \\
\text { nokságok eseté- } \\
\text { ben, egy meccs } \\
\text { eredmény beje- } \\
\text { lentésekor vagy } \\
\text { elfogadásakor } \\
\text { jelenik meg. }\end{array}$ \\
\hline $\begin{array}{l}\text { Milyen gyakran tekinti meg a } \\
\text { fö ranglista oldalát (ami min- } \\
\text { den felhasználót tartalmaz)? }\end{array}$ & \multirow{2}{*}{$\begin{array}{l}\text { 1) Nem nézem, nem érde- } \\
\text { kel. } \\
\text { 2) Kevesebbszer, mint ha- } \\
\text { vonta } \\
\text { 3) Havonta } 1-2 \text { alkalommal } \\
\text { 4) Hetente } 1-2 \text { alkalommal }\end{array}$} & \multirow{2}{*}{$\begin{array}{l}\text { Többiekhez } \\
\text { viszonyított } \\
\text { teljesít- } \\
\text { mény }\end{array}$} & \multirow{2}{*}{$\begin{array}{l}\text { Általános, pozí- } \\
\text { ció szerint nem } \\
\text { korlátozott meg- } \\
\text { jelenésü. }\end{array}$} \\
\hline $\begin{array}{l}\text { Milyen gyakran tekinti meg a } \\
\text { kicsi ranglistát, ami az }\end{array}$ & & & \\
\hline
\end{tabular}




\begin{tabular}{|c|c|c|c|}
\hline Kérdés & Válasz & Kategória & Megjegyzés \\
\hline $\begin{array}{l}\text { Irányítópult oldalán található } \\
\text { (ami csak a szomszédos fel- } \\
\text { használókat mutatja)? }\end{array}$ & 5) Szinte minden nap & & \\
\hline $\begin{array}{l}\text { Tetszenek és motiválják önt } \\
\text { a játékosszintek állatos témái } \\
\text { (elnevezés és ikonok)? }\end{array}$ & $\begin{array}{l}\text { 1) Nem motiválnak, pedig } \\
\text { fontos lenne számomra. } \\
\text { 2) Nem motiválnak, de nem } \\
\text { is fontos számomra. } \\
\text { 3) Nem nézem. } \\
\text { 4) Igen, bár annyira nem ér- } \\
\text { dekel a szint. } \\
\text { 5) Igen, és fontos is a szá- } \\
\text { momra. }\end{array}$ & \multirow[t]{2}{*}{ Szintek } & \multirow{5}{*}{$\begin{array}{l}\text { Általános, pozí- } \\
\text { ció szerint nem } \\
\text { korlátozott meg- } \\
\text { jelenésü. }\end{array}$} \\
\hline $\begin{array}{l}\text { Meg szokta nézni a saját és } \\
\text { más játékos szintjét? }\end{array}$ & $\begin{array}{l}\text { 1) Nem figyelem, nem ér- } \\
\text { dekel. } \\
\text { 2) Csak a sajátomat. } \\
\text { 3) Csak másét. } \\
\text { 4) Sajátomat és másét egy- } \\
\text { aránt. }\end{array}$ & & \\
\hline $\begin{array}{l}\text { Tetszenek és motiválják önt } \\
\text { a Jelvények? }\end{array}$ & $\begin{array}{l}\text { 1) Nem, pedig szívesen } \\
\text { gyüjteném őket. } \\
\text { 2) Nem motiválnak, de nem } \\
\text { is fontosak számomra. } \\
\text { 3) Nem nézem. } \\
\text { 4) Igen, bár nem vagyok } \\
\text { annyira híve a gyüjtögetés- } \\
\text { nek. } \\
\text { 5) Igen, és szeretem őket } \\
\text { begyüjteni. }\end{array}$ & Jelvények & \\
\hline $\begin{array}{l}\text { Motiválja önt a Karma }{ }^{17} \text { ab- } \\
\text { ban, hogy részt vegyen akti- } \\
\text { vitásokban és kihívásokban? }\end{array}$ & $\begin{array}{l}\text { 1) Egyáltalán nem } \\
\text { 2) Inkább nem } \\
\text { 3) Semleges } \\
\text { 4) Inkább igen } \\
\text { 5) Teljes mértékben }\end{array}$ & Pontok & \\
\hline $\begin{array}{l}\text { Milyen gyakran látogatja } \\
\text { meg más játékos profilolda- } \\
\text { lát? }\end{array}$ & $\begin{array}{l}\text { 1) Nem nézem, nem érde- } \\
\text { kel. } \\
\text { 2) Kevesebbszer, mint ha- } \\
\text { vonta } \\
\text { 3) Havonta } 1-2 \text { alkalommal } \\
\text { 4) Hetente } 1-2 \text { alkalommal } \\
\text { 5) Szinte minden nap }\end{array}$ & Profil & \\
\hline
\end{tabular}

16. táblázat: A szolgáltatás által automatikusan feltett kérdések

${ }^{17}$ A vizsgált szolgáltatásban a pontokat Karmának nevezik. 
2. Melléklet: Használatból eredő sportolási hajlandóságra vonatkozó visszajelzési kérdésekre adott átlagos értékelések időbeli változása

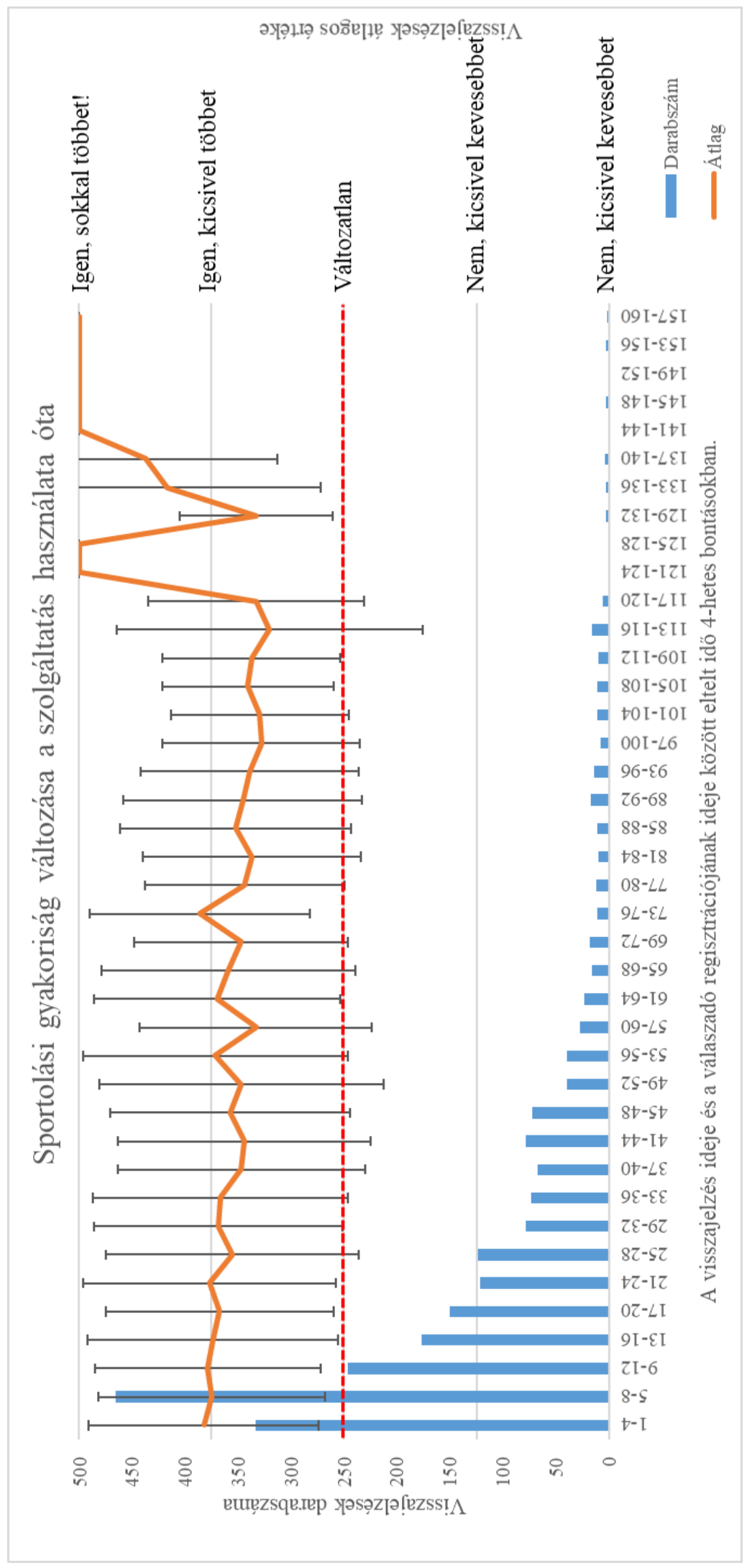

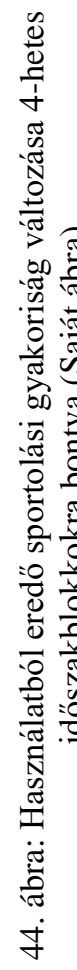




\section{Melléklet: 1. körös FUT-kérdések}

\begin{tabular}{|c|c|c|c|}
\hline$\#$ & Kérdés & Opció & Opcióleírás \\
\hline \multirow{2}{*}{ Q1 } & \multirow{2}{*}{$\begin{array}{l}\text { Melyik jutalmat vá- } \\
\text { lasztanád inkább? }\end{array}$} & Garfield jelvény & $\begin{array}{l}\text { Nyerni egy meccset hétfö reggel, mikor } \\
\text { még mindenki álmos. }\end{array}$ \\
\hline & & Olimpikon jelvény & $\begin{array}{l}\text { Nyerni legalább } 3 \text { különböző verse- } \\
\text { nyen. }\end{array}$ \\
\hline \multirow{2}{*}{ Q2 } & \multirow{2}{*}{$\begin{array}{l}\text { Képzeld el, hogy ép- } \\
\text { pen társasjátékozol a } \\
\text { barátaiddal. Mi jel- } \\
\text { lemző rád? }\end{array}$} & Mindent a nyerésért! & $\begin{array}{l}\text { Mindig a nyerésért játszol, bármi történ- } \\
\text { jék is. }\end{array}$ \\
\hline & & $\begin{array}{l}\text { A lényeg, hogy jól szórakoz- } \\
\text { zunk... }\end{array}$ & $\begin{array}{l}\text { Csak a játék élvezetéért játszol, nem is } \\
\text { figyeled a pontokat. }\end{array}$ \\
\hline \multirow{2}{*}{ Q3 } & \multirow{2}{*}{$\begin{array}{l}\text { Csapatépítés kapcsán } \\
\text { miben lennél benne } \\
\text { inkább? }\end{array}$} & Túrázzunk együtt az erdőben & $\begin{array}{l}\text { Jobb szeretsz kimozdulni és közösen } \\
\text { aktívan pihenni. }\end{array}$ \\
\hline & & Munka után igyunk egyet & $\begin{array}{l}\text { Inkább bent maradsz és pihensz egyet } \\
\text { munka után. }\end{array}$ \\
\hline \multirow{2}{*}{ Q4 } & \multirow{2}{*}{$\begin{array}{l}\text { Hogyan képzelnéd el } \\
\text { magad inkább? }\end{array}$} & Edzőteremben kardiózom & $\begin{array}{l}\text { Inkább edzőteremben mégy, minthogy } \\
\text { egy csapatban játssz a haverokkal. }\end{array}$ \\
\hline & & $\begin{array}{l}\text { Labdajátékot üzök a baráta- } \\
\text { immal }\end{array}$ & $\begin{array}{l}\text { Inkább csapatban játszol, ahelyett, hogy } \\
\text { egyedül edzenél. }\end{array}$ \\
\hline \multirow{2}{*}{ Q5 } & \multirow{2}{*}{$\begin{array}{l}\text { Ha választanod kéne, } \\
\text { melyiket preferálnád? }\end{array}$} & Videojátékok & $\begin{array}{l}\text { Te inkább egy wow-csgo-lol-dota-stb } \\
\text { típusú ember vagy. }\end{array}$ \\
\hline & & Valós sakk & $\begin{array}{l}\text { Jobb szereted a személyes játszmákat, } \\
\text { szemtől szemben. }\end{array}$ \\
\hline
\end{tabular}

17. táblázat: 1. körös FUT-kérdések és válaszopciói ( (Barna \& Fodor, 2018d) alapján saját szerkesztés)

A kérdéseket eredeti nyelven, az opciókhoz tartozó vizuális megjelenítéssel a Hiba! A hivatkozási forrás nem található. tartalmazza összeszerkesztett formában. 


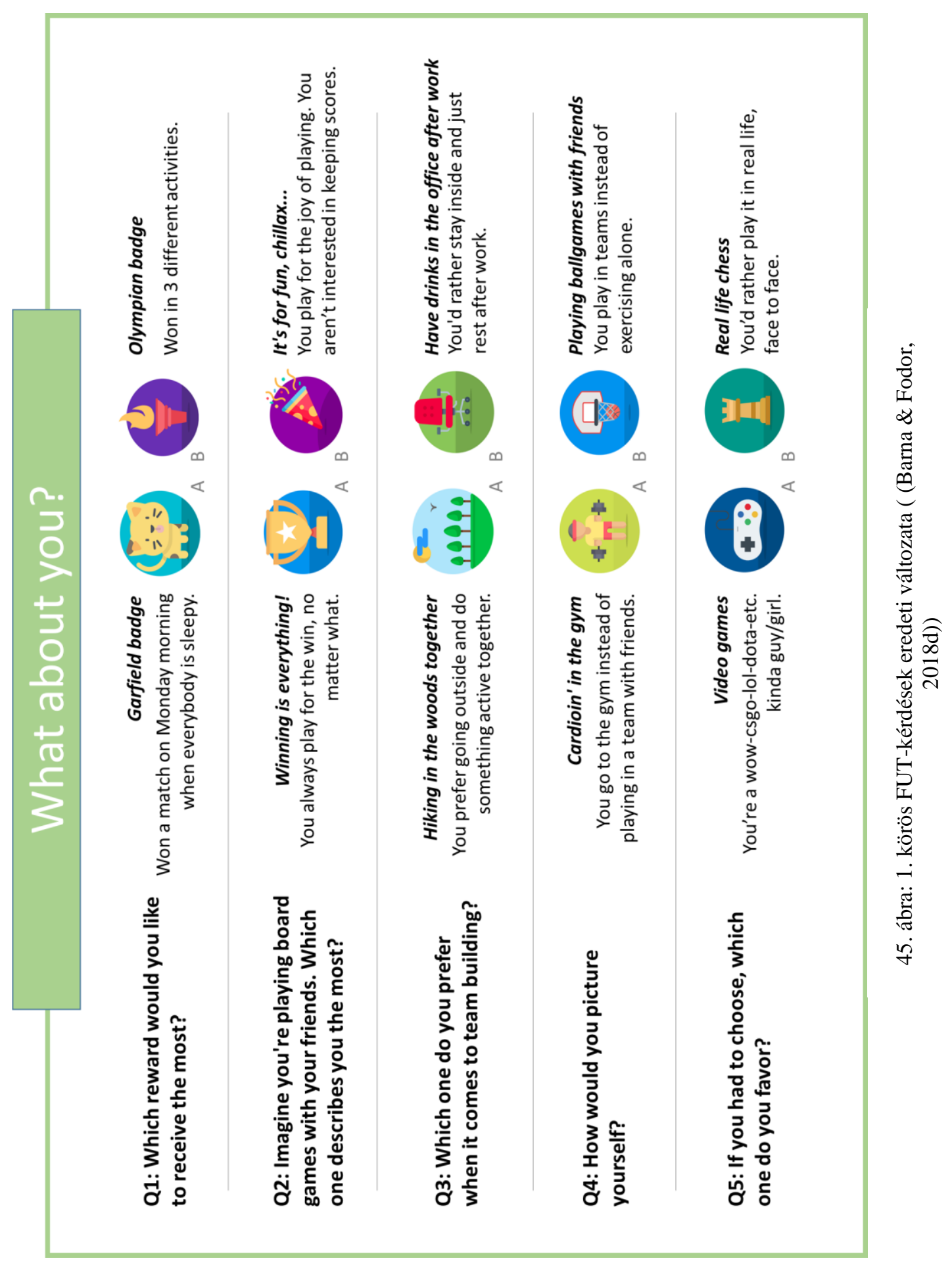




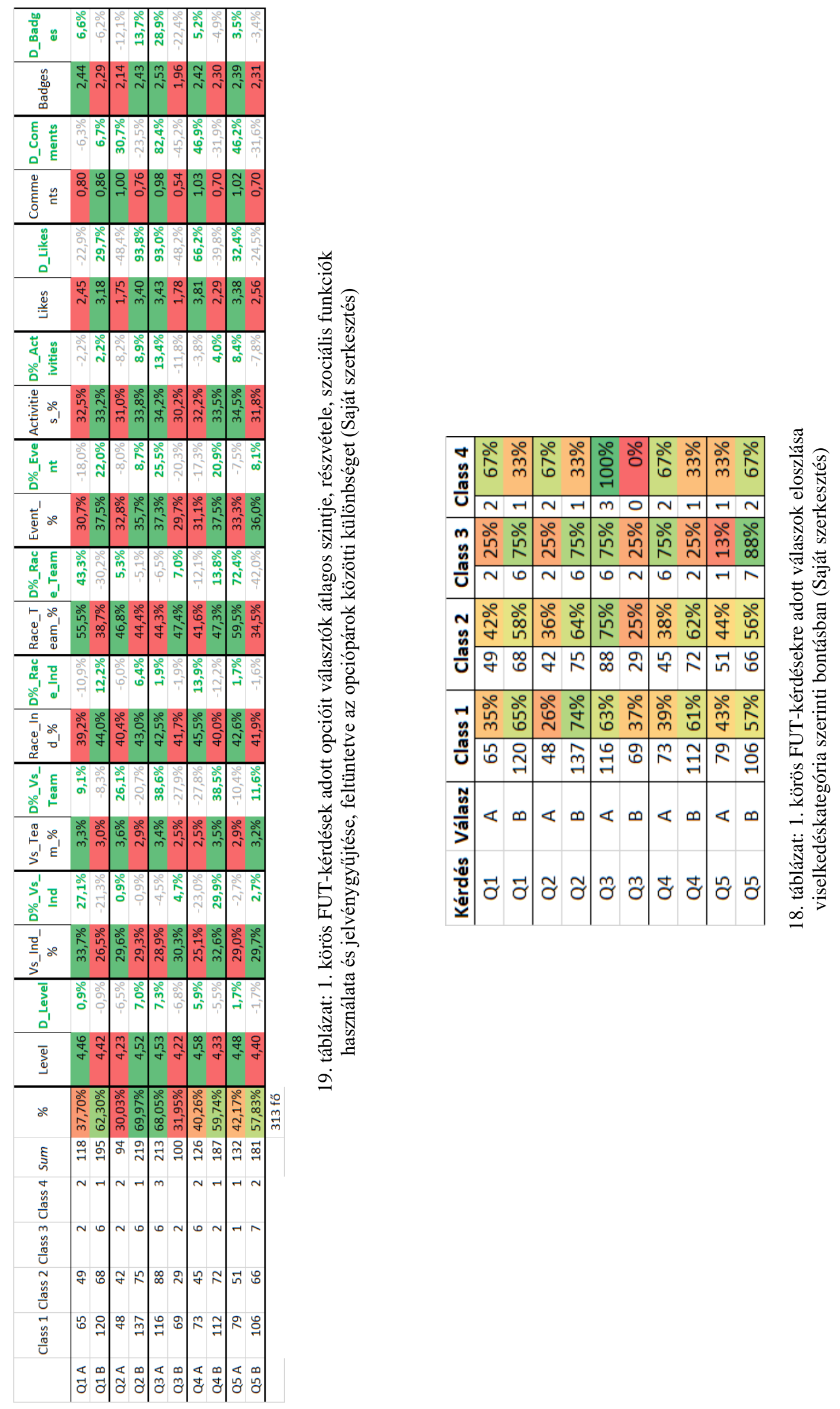




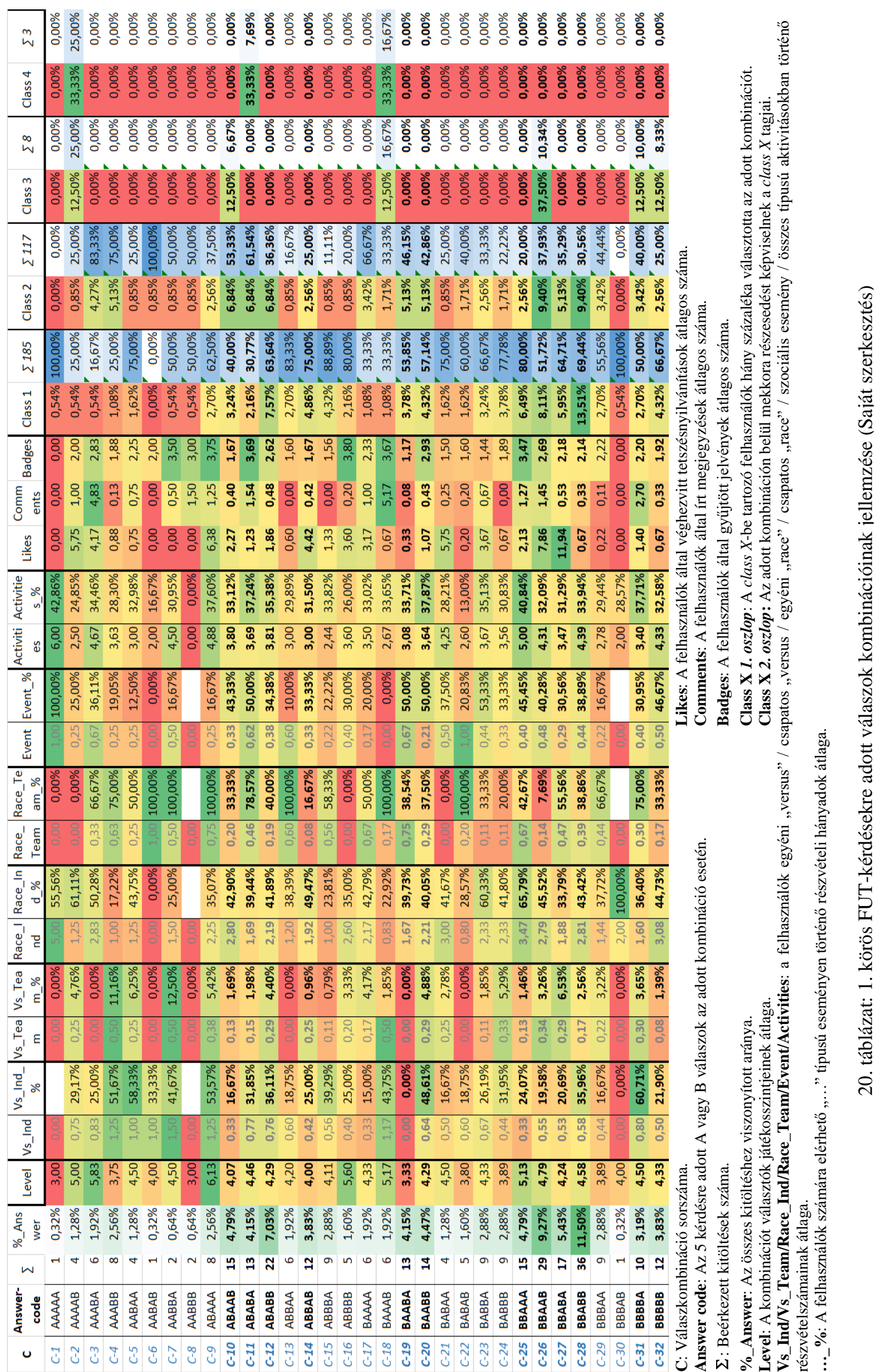




\section{Melléklet: 2. körös FUT-kérdések}

\begin{tabular}{|c|c|c|c|}
\hline$\#$ & Kérdés & Opció & Opcióleírás \\
\hline \multirow[t]{2}{*}{ Q1 } & \multirow{2}{*}{$\begin{array}{l}\text { Mennyire ismered jól } \\
\text { a kollégáidat? }\end{array}$} & Nem igazán & $\begin{array}{l}\text { Van néhány ismerős arc, de a munkatár- } \\
\text { sak többségével legfeljebb néhány szót } \\
\text { váltottam. }\end{array}$ \\
\hline & & Egy csapat vagyunk & $\begin{array}{l}\text { A többségüket elég jól ismerem és élve- } \\
\text { zem a társaságukat. }\end{array}$ \\
\hline \multirow{2}{*}{ Q2 } & \multirow{2}{*}{$\begin{array}{l}\text { Itt a csapatépítés } \\
\text { ideje! Milyen hosszú } \\
\text { legyen? }\end{array}$} & Minél több, annál jobb & $\begin{array}{l}\text { A hosszú eseményeket szeretem, néme- } \\
\text { lyik akár hetekig is eltarthat. }\end{array}$ \\
\hline & & A kevesebb néha több & $\begin{array}{l}\text { Legyen rövid, ám velős. Nem akarok túl } \\
\text { sok időt eltölteni vele. }\end{array}$ \\
\hline \multirow{2}{*}{ Q3 } & \multirow{2}{*}{$\begin{array}{l}\text { Épp egy unalmas } \\
\text { szombat délutánod } \\
\text { van. Mit teszel? }\end{array}$} & Szórakozzunk egy kicsit! & $\begin{array}{l}\text { Elvégre hétvége van! Szeretnék ját- } \\
\text { szani, partizni, túrázni vagy szimplán } \\
\text { jól érezni magam. }\end{array}$ \\
\hline & & Valami produktívat & $\begin{array}{l}\text { Olvasnék egy könyvet, másodprojekten } \\
\text { dolgoznék, online kurzust néznék vagy } \\
\text { bármit, amivel fejlődöm. }\end{array}$ \\
\hline \multirow{2}{*}{ Q4 } & \multirow{2}{*}{$\begin{array}{l}\text { Hogyan viszonyulsz a } \\
\text { sportokhoz? }\end{array}$} & Imádom & $\begin{array}{l}\text { Több, mint boldog vagyok, ha a sporto- } \\
\text { lásnak szentelhetem magam. Szeretem a } \\
\text { megmérettetést, ha kitolhatom a határa- } \\
\text { imat és feltöltődöm energiával. }\end{array}$ \\
\hline & & Szükséges rossz & $\begin{array}{l}\text { Tudom, hogy jót tesz az egészségem- } \\
\text { nek, de inkább tünik számomra házi- } \\
\text { munkának, mintsem egy élvezetes do- } \\
\text { lognak. }\end{array}$ \\
\hline \multirow{2}{*}{ Q5 } & \multirow{2}{*}{$\begin{array}{l}\text { Egy bonyolult felad- } \\
\text { vány hever előtted. } \\
\text { Mi az első gondola- } \\
\text { tod? }\end{array}$} & Kihívás elfogadva & $\begin{array}{l}\text { Meg kell fejtenem! Nincs az a felad- } \\
\text { vány, mely kifoghat rajtam. }\end{array}$ \\
\hline & & Nem, köszi & $\begin{array}{l}\text { Nem izgat fel, inkább hátradőlök és pi- } \\
\text { henek, minthogy foglalkozzak vele. }\end{array}$ \\
\hline
\end{tabular}

21. táblázat: 2. körös FUT-kérdések és válaszopciói (Saját szerkesztés) 

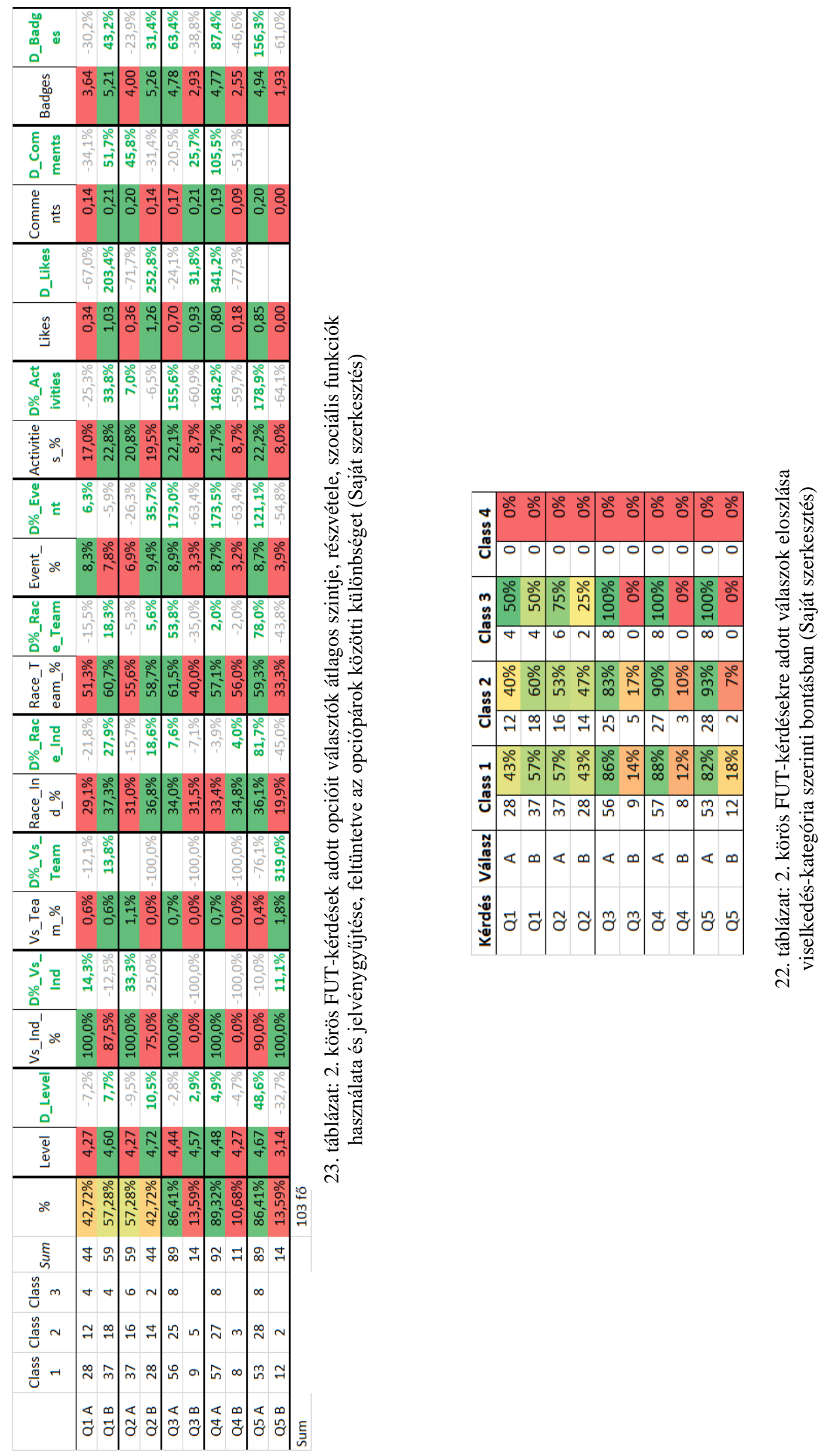


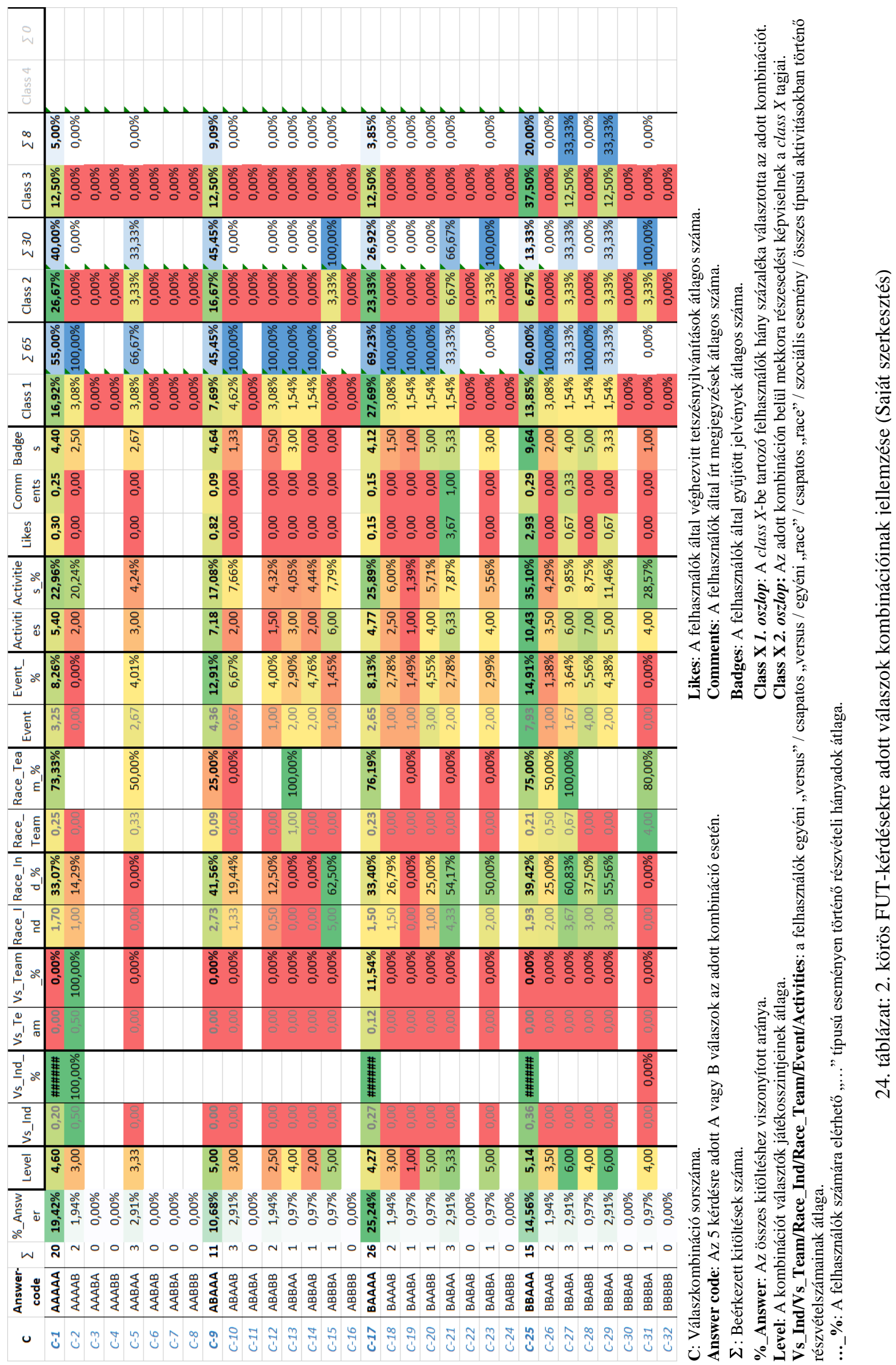

